\title{
Guia prático para reprodução de paisagens
}

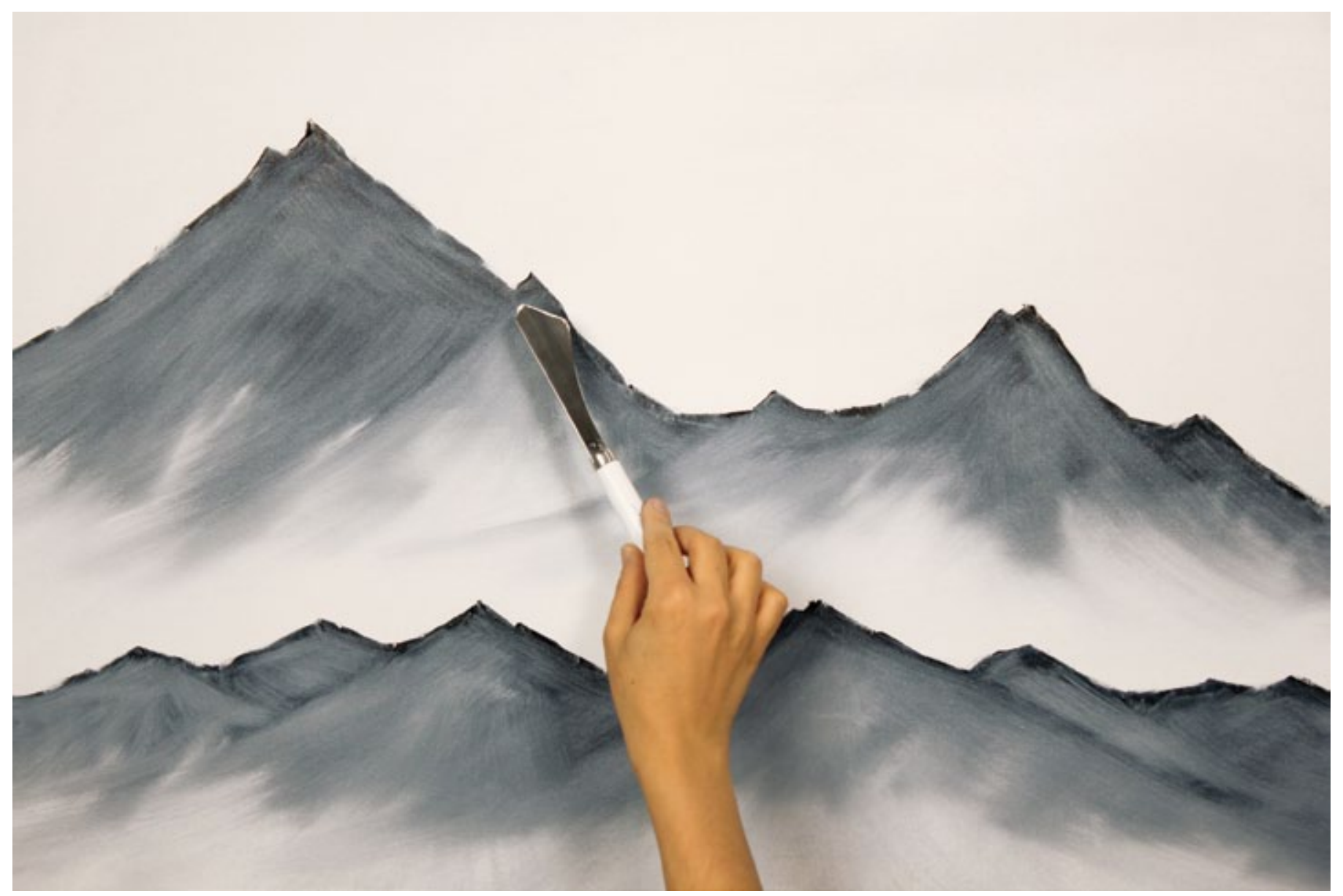



UNIVERSIDADE DE SÃO PAULO

Escola de Comunicações e Artes

Programa de Pós-Graduação em Artes Visuais

\section{Guia prático \\ para reprodução \\ de paisagens}

\section{Laura Huzak Andreato}

Dissertação apresentada ao Programa de Pós-Graduação em Artes Visuais da Escola de Comunicações e Artes da Universidade de São Paulo, como requisito parcial para a obtenção do título de Mestre em Artes Visuais

Orientador: Prof. Dr. Carlos Alberto Fajardo

São Paulo, 2015 
Autorizo a reprodução e divulgação total ou parcial deste trabalho, por qualquer meio convencional ou eletrônico, para fins de estudo e pesquisa, desde que citada a fonte.

Catalogação na Publicação

Serviço de Biblioteca e Documentação

Escola de Comunicações e Artes da Universidade de São Paulo

Dados fornecidos pelo(a) autor(a)

Andreato, Laura Huzak

Guia prático para reprodução de paisagens / Laura Huzak

Andreato. -- São Paulo: L. . H. Andreato, 2015.

165 p.: il. + inclui dvd.

Dissertação (Mestrado) - Programa de Pós-Graduação em Artes Visuais - Escola de Comunicações e Artes / Universidade de São Paulo.

Orientador: Prof. Dr. Carlos Alberto Fajardo

Bibliografia

1. arte contemporânea 2. poéticas visuais 3. paisagem 4 . imagem 5. reprodução I. Fajardo, Prof. Dr. Carlos Alberto II. Título.

CDD 21.ed. - 700 
Laura Huzak Andreato

Guia prático para representação de paisagens

Dissertação apresentada ao Programa de Pós-Graduação em Artes Visuais da Escola de Comunicações e Artes da Universidade de São Paulo, como requisito parcial para a obtenção do título de Mestre em Artes Visuais.

Orientador Prof. Dr. Carlos Alberto Fajardo

Aprovado em:

Banca Examinadora: 

Iolanda Huzak,

Elifas Andreato,

João Rocha Rodrigues,

Nuno Andreato Rodrigues.

e a El Gran Somar, el Mago de Todos los Mistérios 



\section{agradecimentos}

João Rocha Rodrigues, Liliane Benetti, Carlos Eduardo Riccioppo, Marcia Pastore e Ana Cândida Avelar.

Thais Rivitti, Marcelo Amorim, Rodrigo Grasso, Pedro Galego, Dennis Vecchione, Henriette Helfant, Pedro Sanches, Vera Pallamin, Sônia Salztein e Carlos Fajardo.

Raphael Fonseca, Ana Luiza Dias Batista, João Loureiro, Wagner Morales, Beatriz Toledo, Cayo Honorato, Têra Queiroz, Jane Santana, Celinha Azevedo, Neusa Martins e Tom Zé.

À família.

Aos amigos. 



\section{Resumo}

Este trabalho aborda processos de produção de obras de arte, partindo de uma investigação sobre a paisagem e suas manifestações no cotidiano. Sob forma de manual, reúne procedimentos e conceitos que auxiliam na produção de trabalhos de arte contemporânea, tais como instruções ilustradas e um glossário de termos e fundamentos importantes para a discussão sobre o tema. Apresenta reflexões sobre a paisagem que abrangem desde sua constituição como fenômeno moderno até os processos de reificação e dissolução no cotidiano, pelos quais passa na contemporaneidade.

ANDREATO, Laura H. Guia prático para representação de paisagens. 2015 Dissertação (Mestrado) - Escola de Comunicações e Artes, Universidade de São Paulo, São Paulo, 2015

Palavras-chave: arte contemporânea, poéticas visuais, paisagem, imagem, reprodução.

\section{Abstract}

This work approaches processes of artworks production, starting from an investigation on the landscape and its manifestations in everyday life. In the form of manual it brings together concepts and procedures that assist in the production of contemporary art works, such as illustrated instructions and a glossary of terms and important theoretical foundations for the discussion on the topic. It presents reflections on the landscape which ranges from its establishment as a modern phenomenon to the reification processes and dissolution in everyday life, through which passes in contemporaneousness.

ANDREATO, Laura H. Guia prático para representação de paisagens. 2015 Dissertação (Mestrado) - Escola de Comunicações e Artes, Universidade de São Paulo, São Paulo, 2015

Keywords: Contemporary art, visual poetics, landscape, image, reproduction. 



\section{sumário}

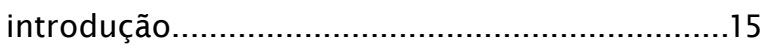

caderno de imagens .........................................17

verbetes.........................................................

instruções para construção de obras....................85

referências bibliográficas................................159

créditos das imagens.......................................164 



\section{Introdução}

Produzir trabalhos de arte contemporânea não é uma tarefa simples. Requer-se o domínio de diversos procedimentos e técnicas, muitas vezes desconhecidos a quem se aventura nesse universo. Refletir criticamente sobre sua própria produção é também uma tarefa árdua. Seja no circuito artístico, no ambiente acadêmico ou escolar, exige-se do artista que ele dê respostas conceituais e teóricas cada vez mais aprofundadas sobre sua produção.

Este guia pretende ajudar aqueles que desejam realizar trabalhos de arte contemporânea cujo tema específico seja a imagem da paisagem e suas manifestações no cotidiano, reunindo os conceitos e procedimentos necessários.

Para tal finalidade, apresenta-se em formato inovador: além do passo-a-passo para a realização dos trabalhos, oferece também ao aprendiz um glossário de termos e conceitos importantes para a reflexão sobre a produção realizada. São citações de importantes escritores, filósofos, críticos e outros pensadores, organizadas não em ordem alfabética, mas de forma a articular um discurso linear que abarca o tema da paisagem desde sua constituição como fenômeno moderno até o processo de reificação e dissolução no cotidiano pelo qual passa na contemporaneidade.

Esta publicação conta ainda com um caderno de imagens que funciona como uma introdução ao tema, demonstrando as mais diversas formas em que reproduções de paisagens podem ser encontradas no dia-a-dia. Assim como os verbetes, essas imagens visam enriquecer o repertório do leitor e contribuir para que ele tenha uma experiência de aprendizado satisfatória.

As instruções para a realização das obras de arte contemporânea são claras, detalhadas e ricamente ilustradas com exemplos de obras já produzidas pela autora.

Anexado ao final deste volume você encontrará ainda um brinde: um DVD contendo o vídeo Como Pintar Picos Nevados. Com ele, poderá apender a pintar belos picos nevados utilizando a técnica de pintura wet-on-wet - ou úmido sobre úmido.

\section{O que você irá aprender neste manual:}

- Como produzir pertinentes trabalhos de arte contemporânea que tenham como tema central a relação entre natureza e cultura, tratando mais especificamente da paisagem e de sua inserção enquanto imagem na vida cotidiana;

- Como utilizar corretamente procedimentos tais como a representação da natureza, a simulação de ambientes naturais, a transformação de elementos da paisagem natural em ícones e símbolos ao produzir obras de arte;

- Como construir um discurso linear e coerente a partir do diálogo entre as obras de arte produzidas e referenciais teóricos;

- Como pintar picos nevados. 

caderno de imagens 


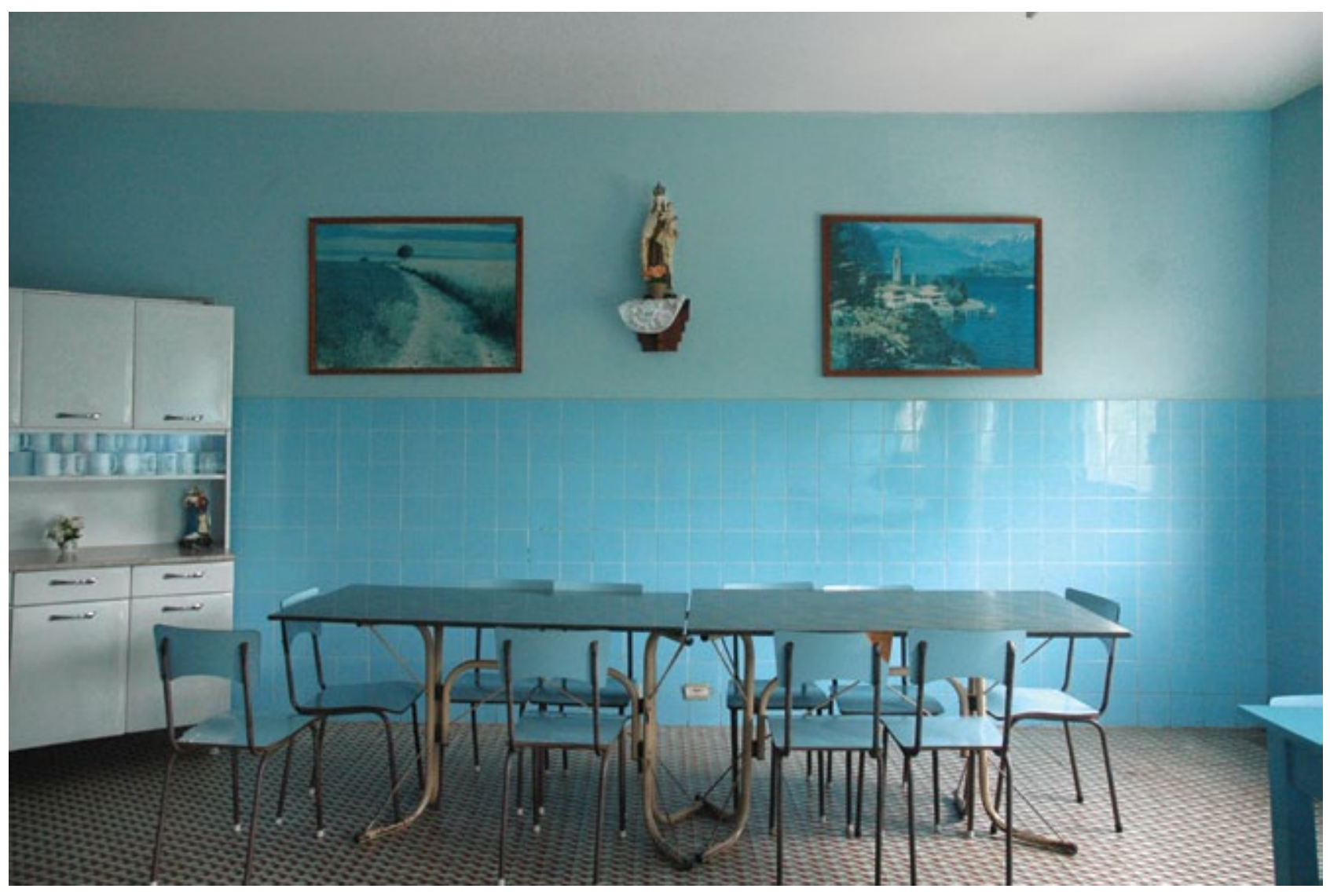




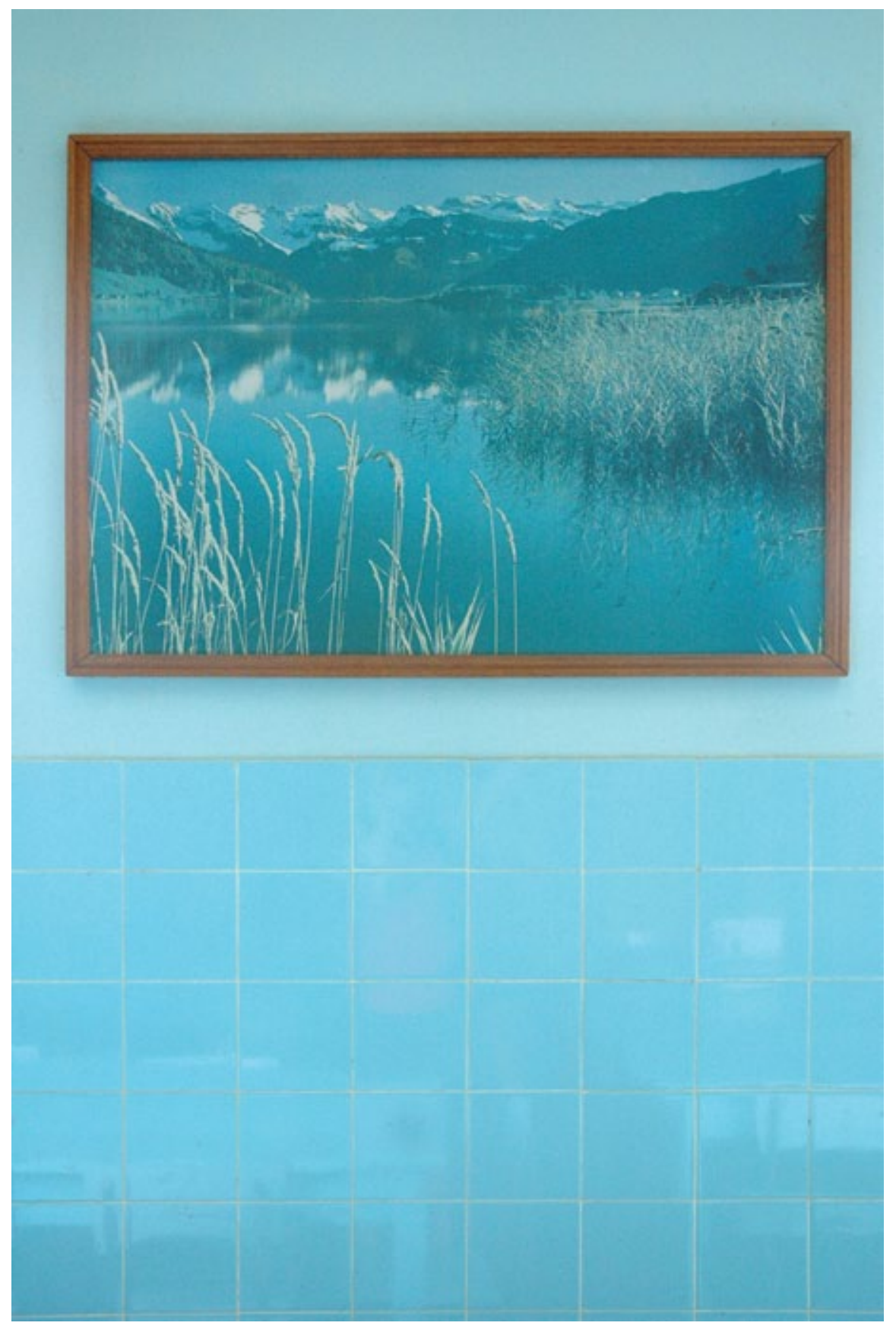




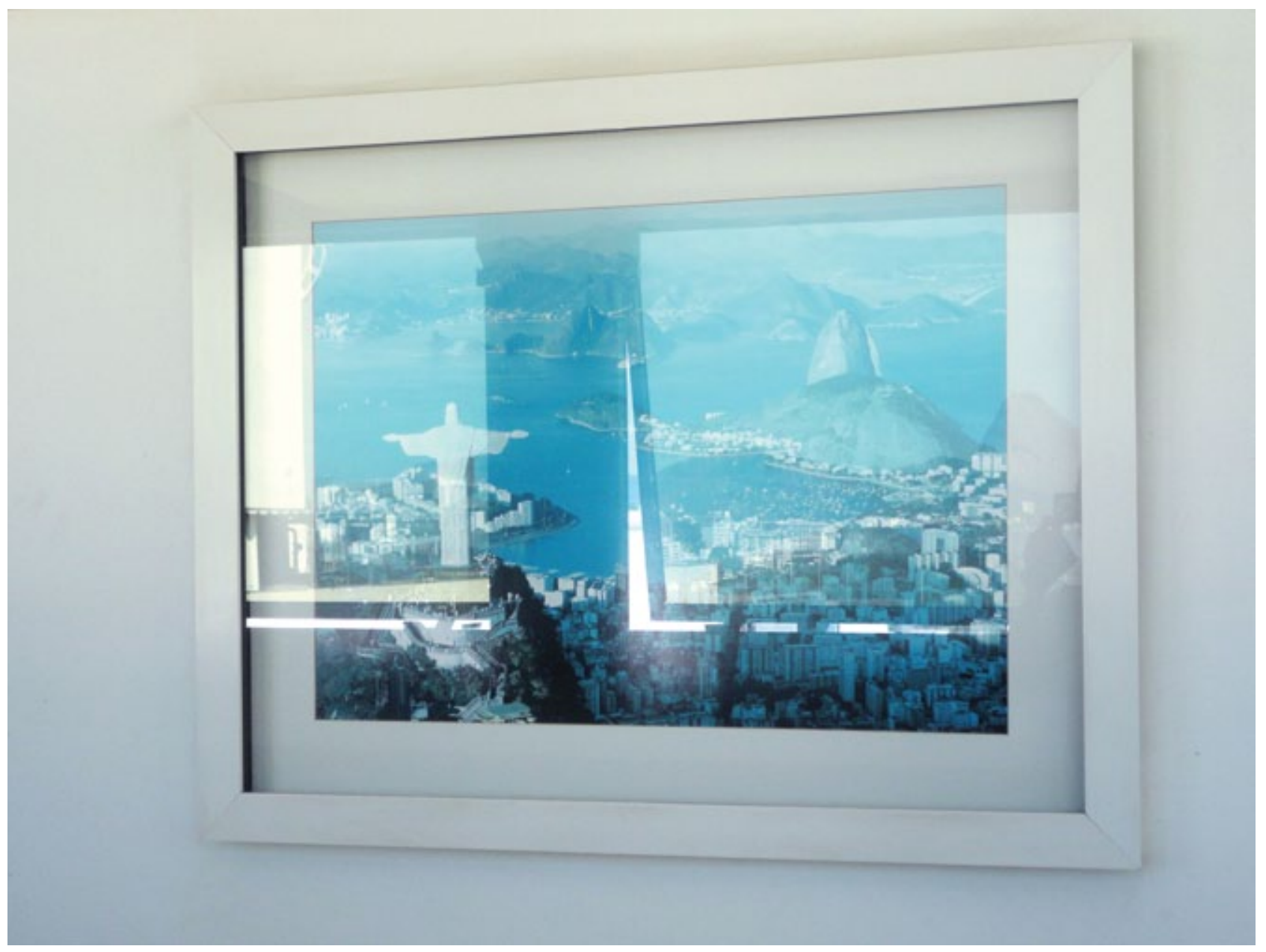




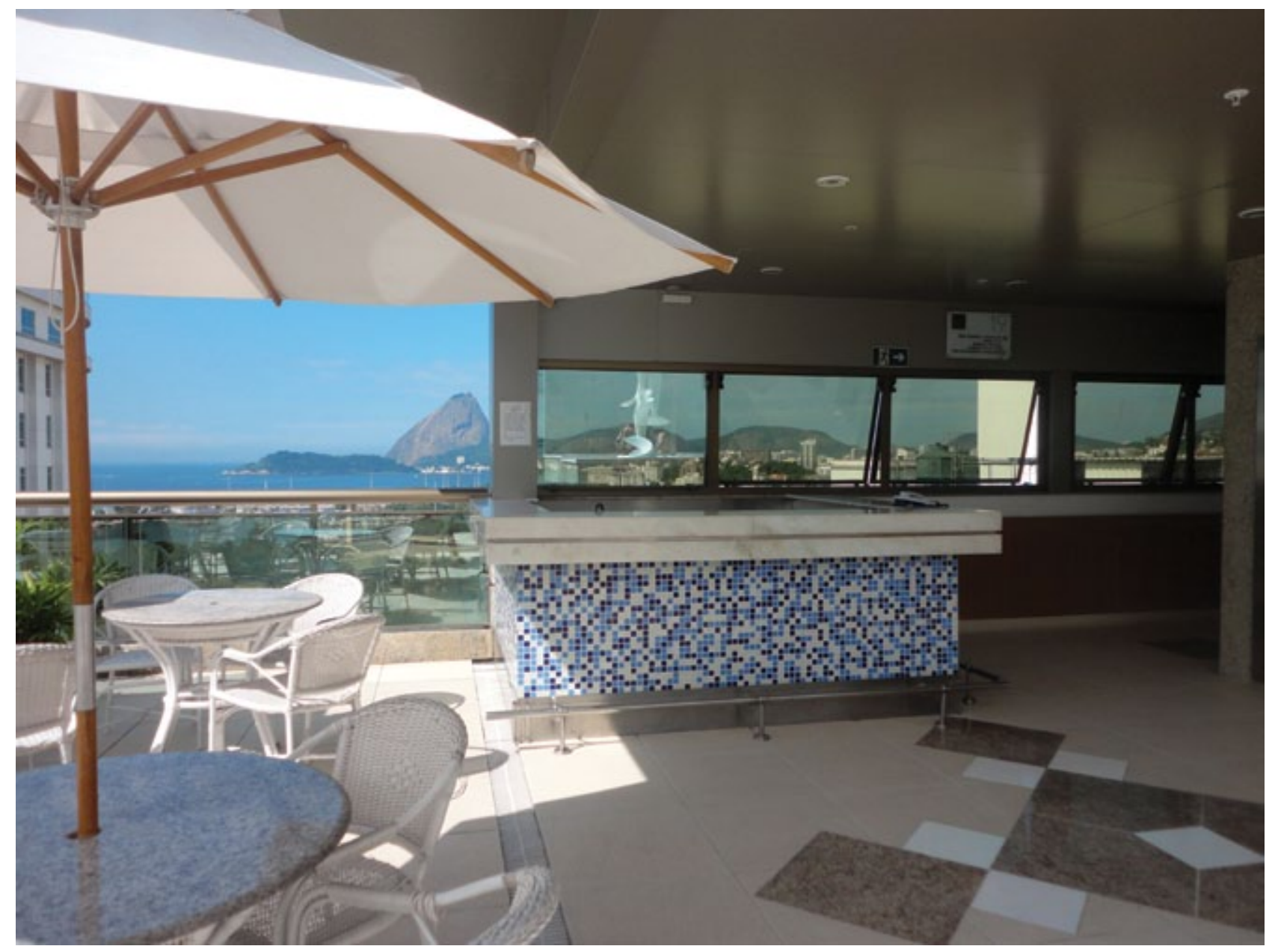




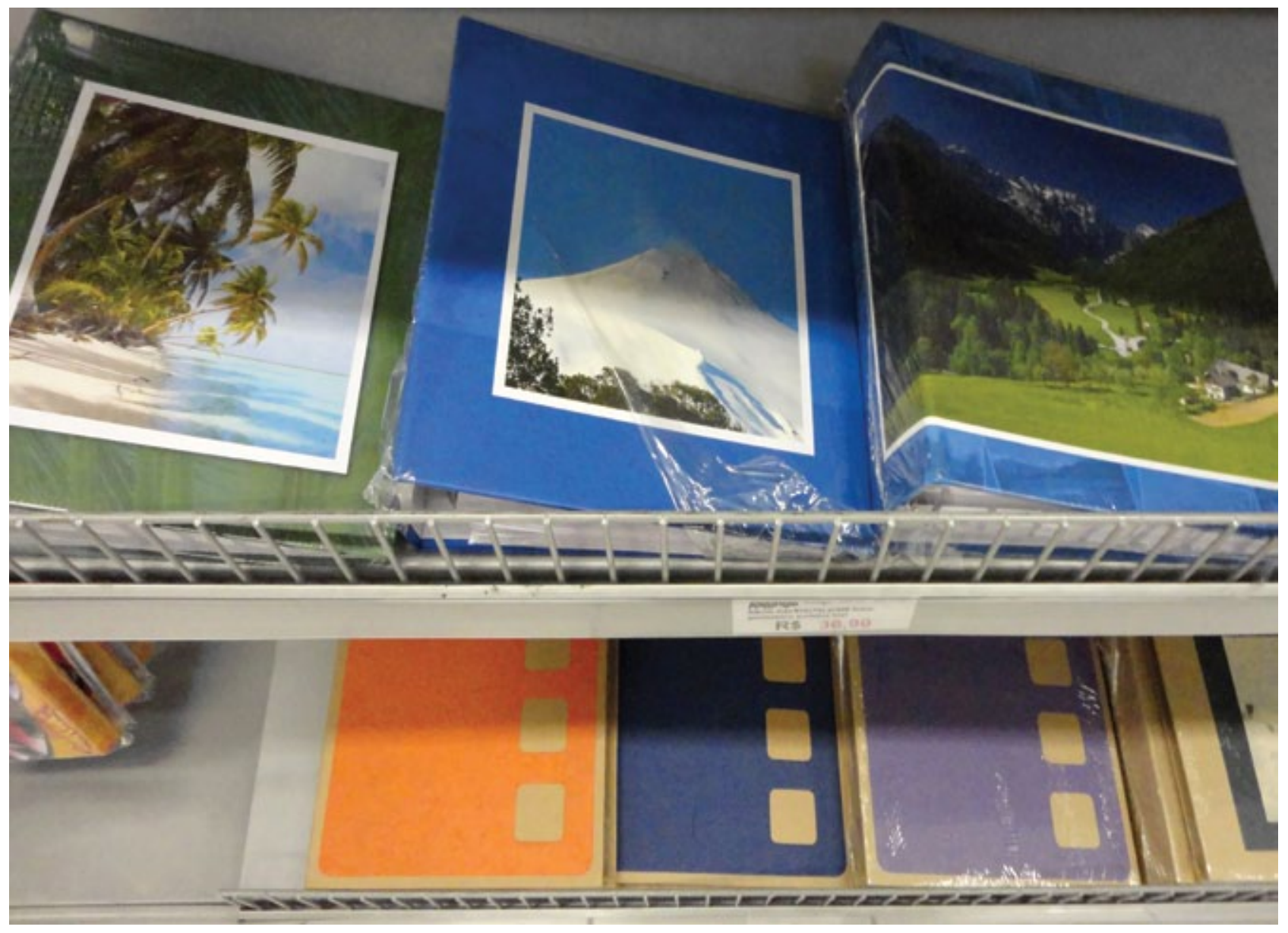




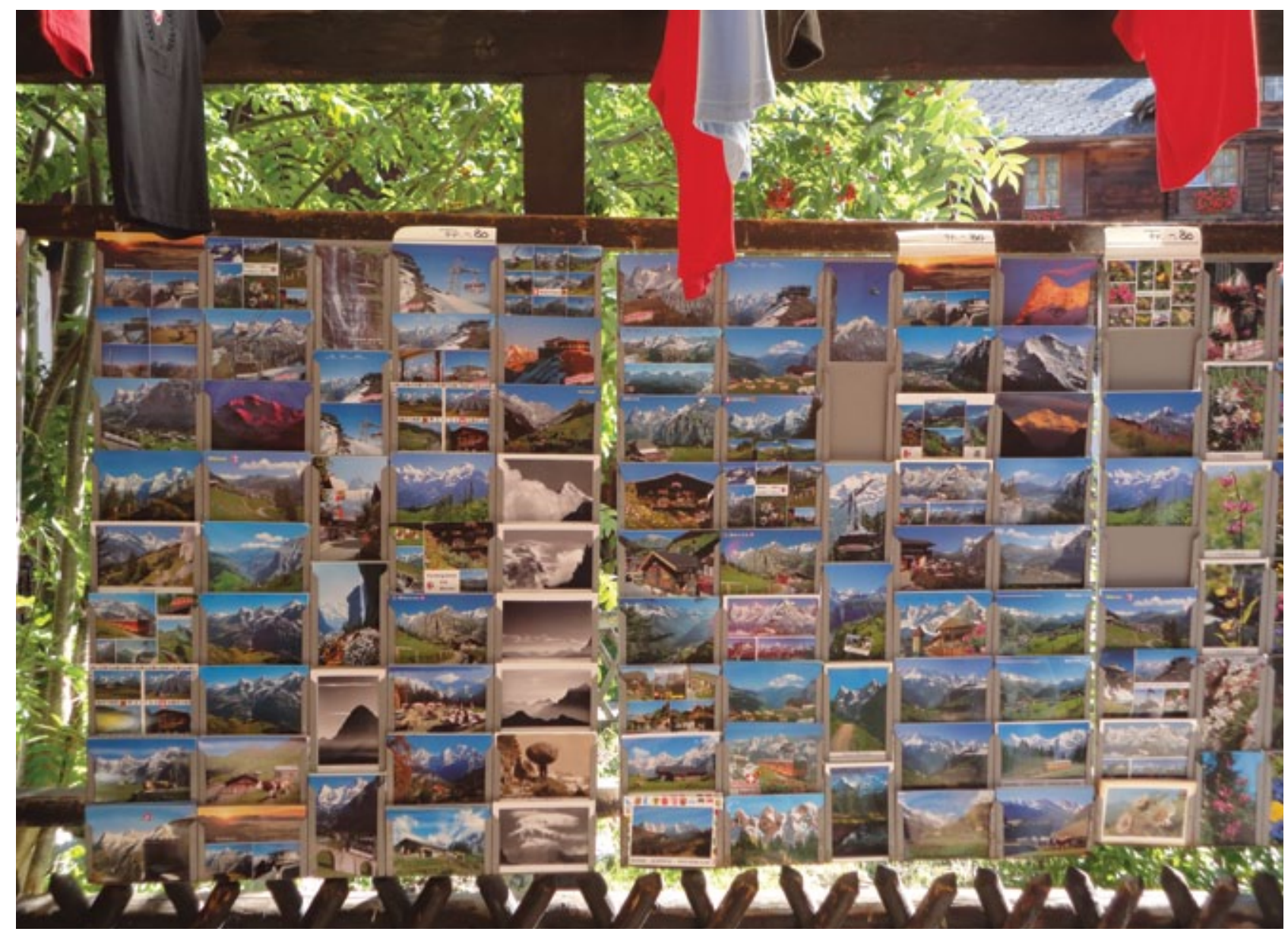




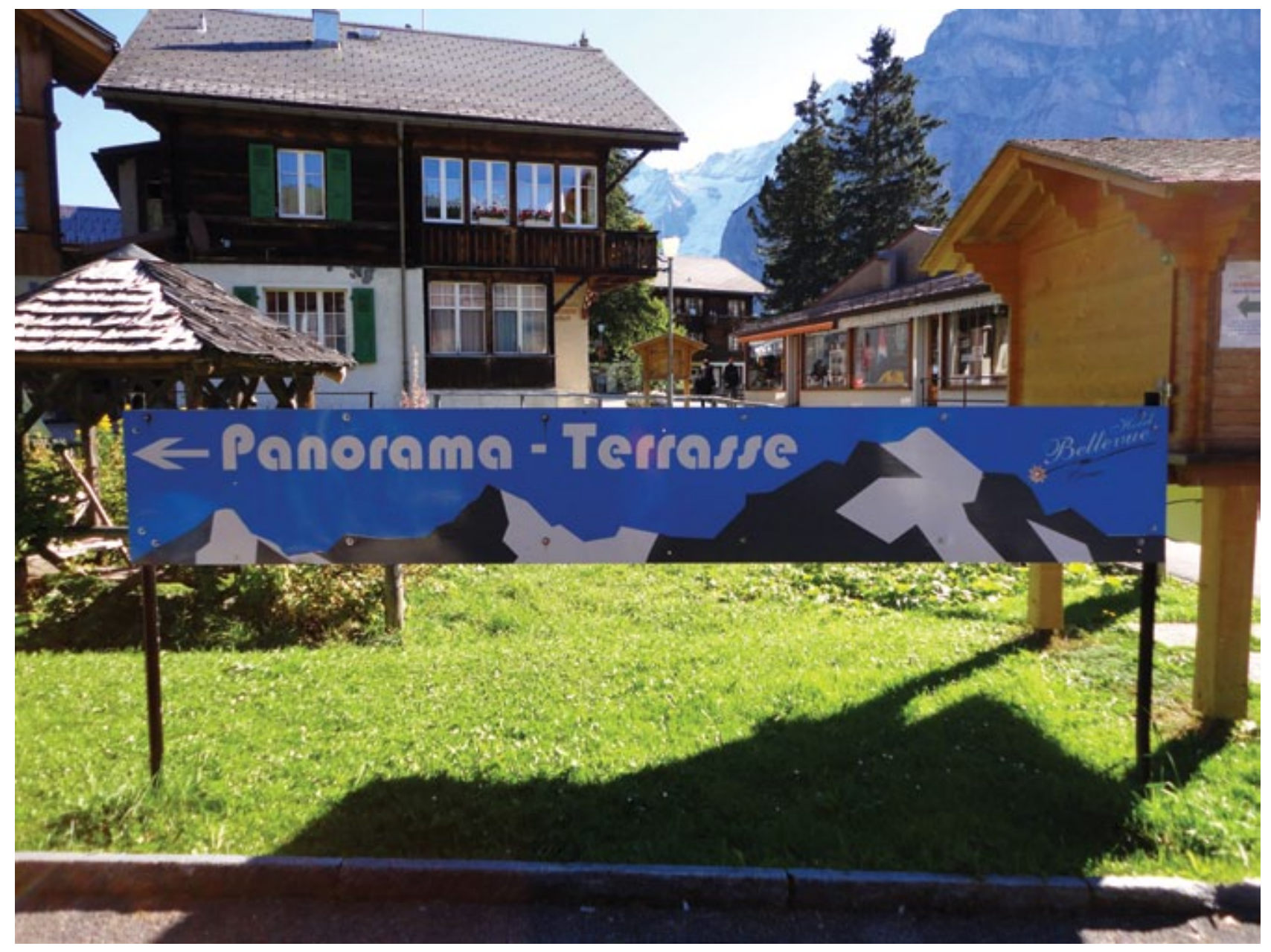




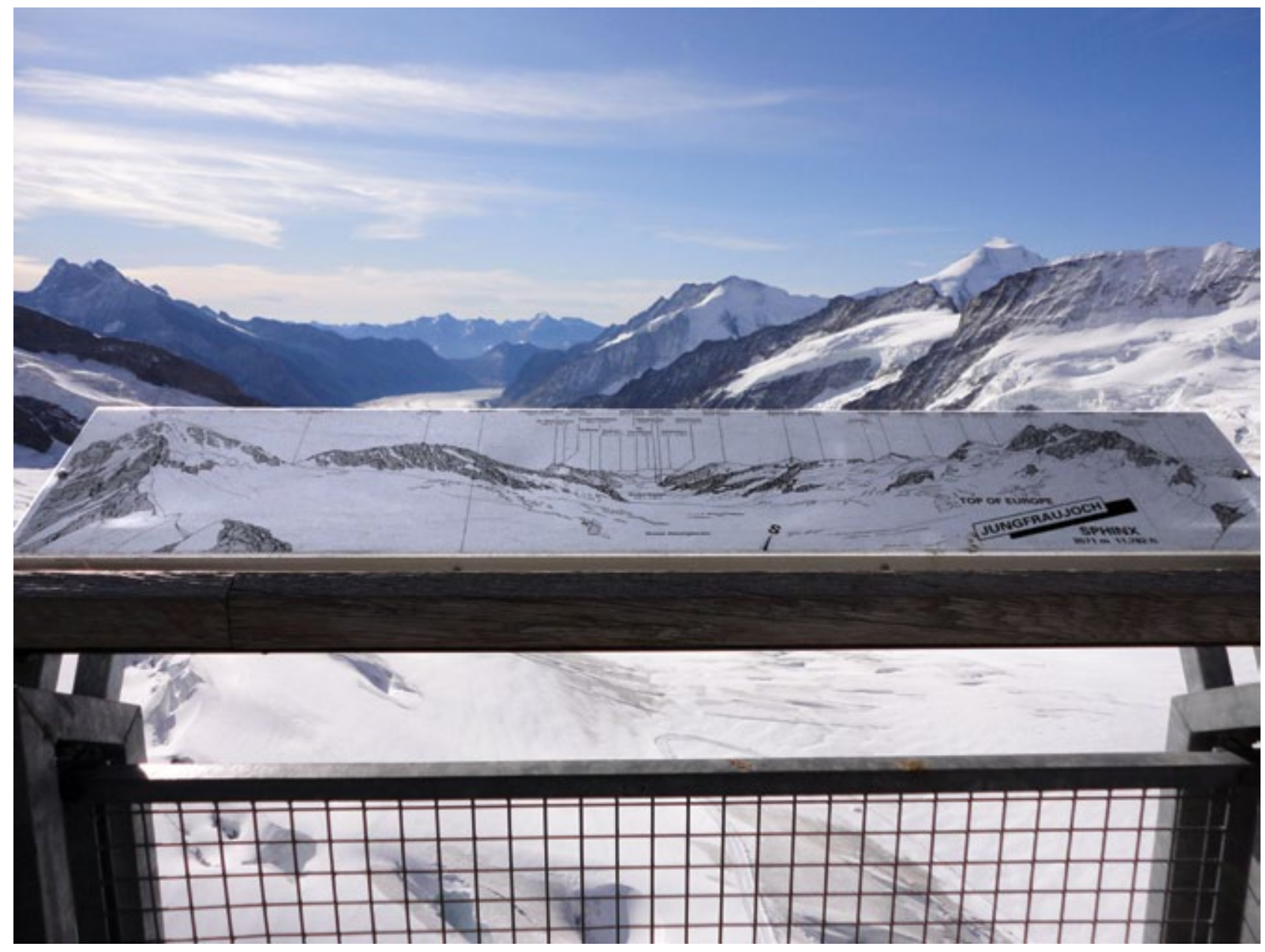




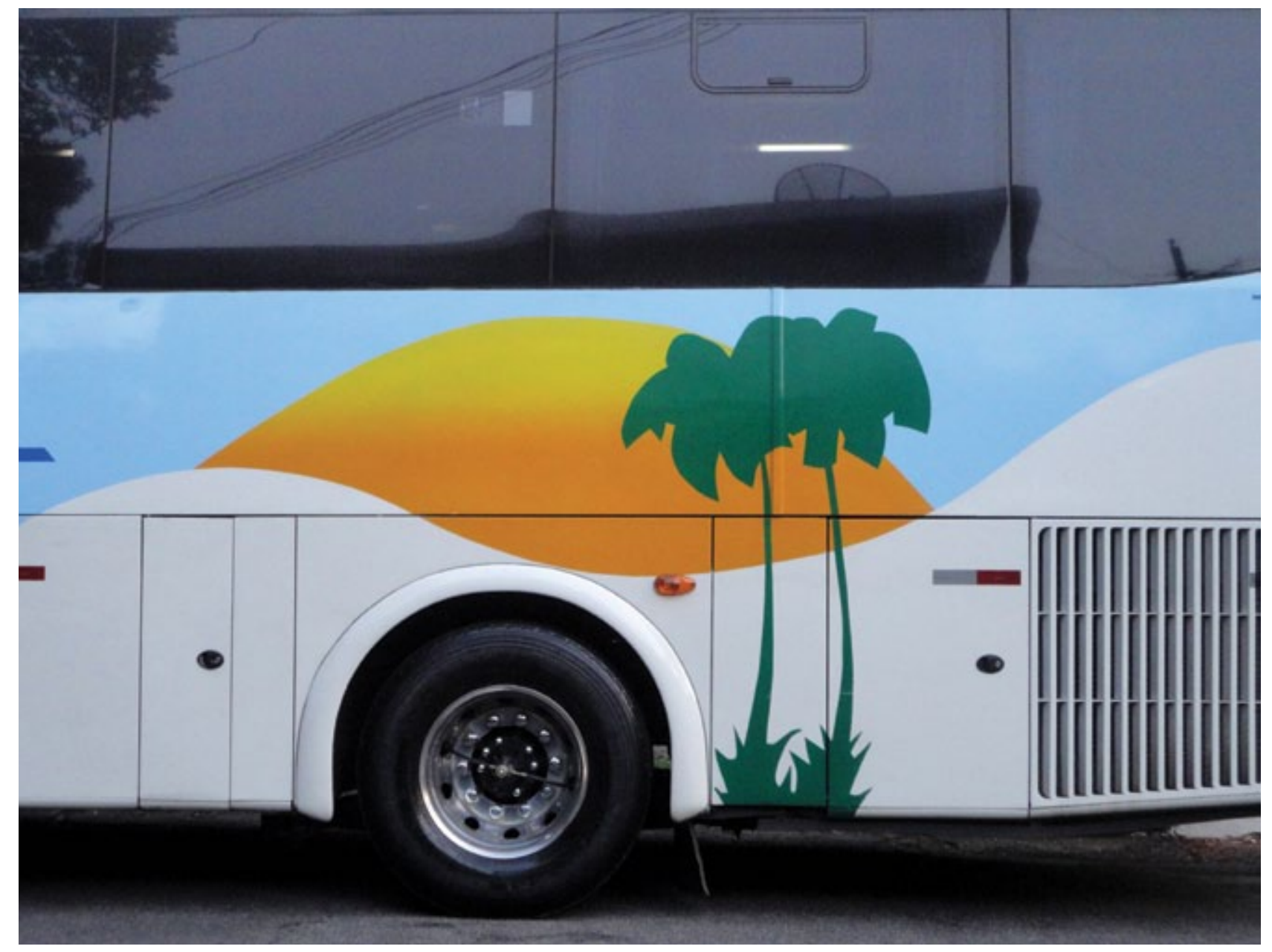




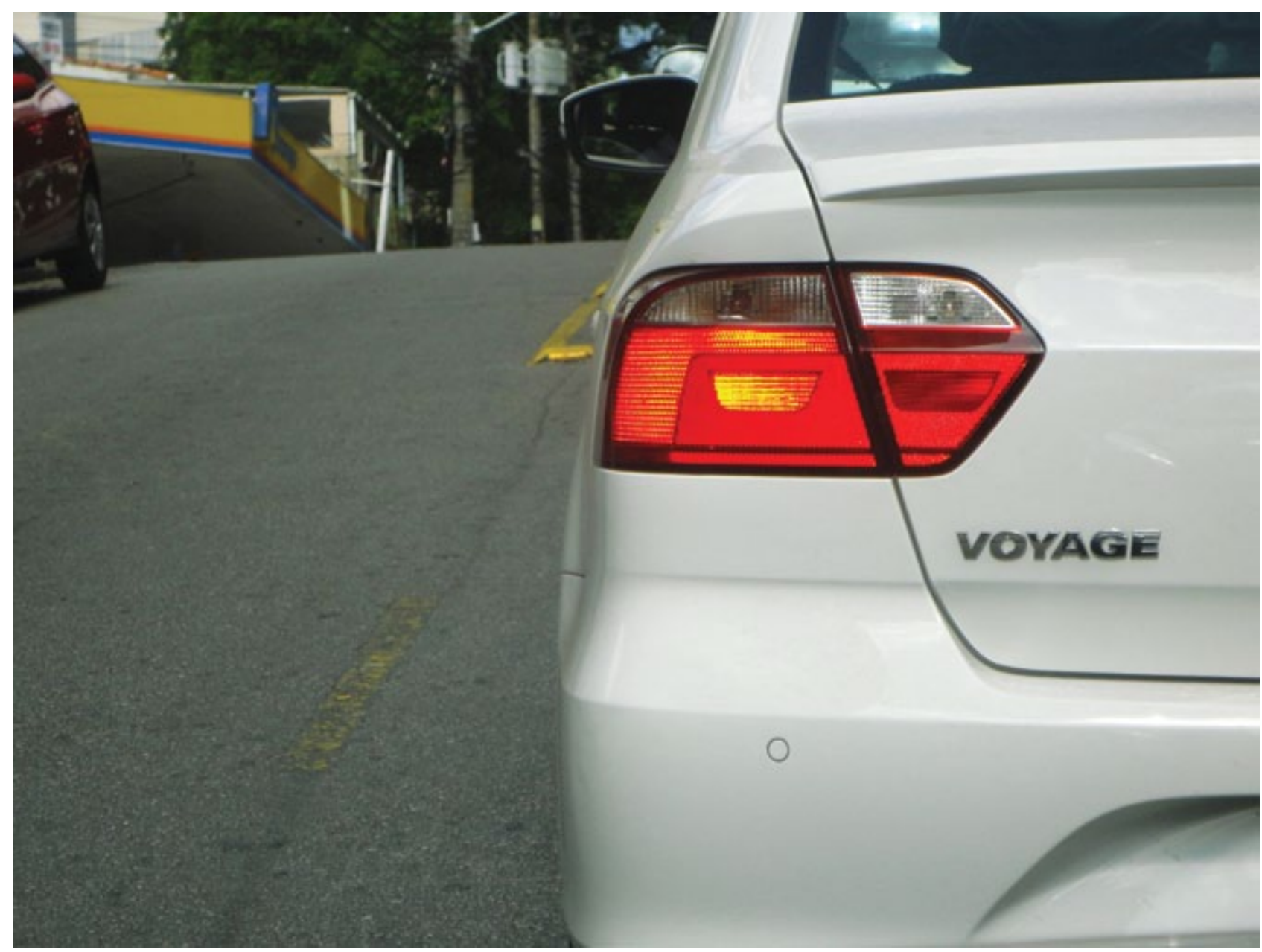




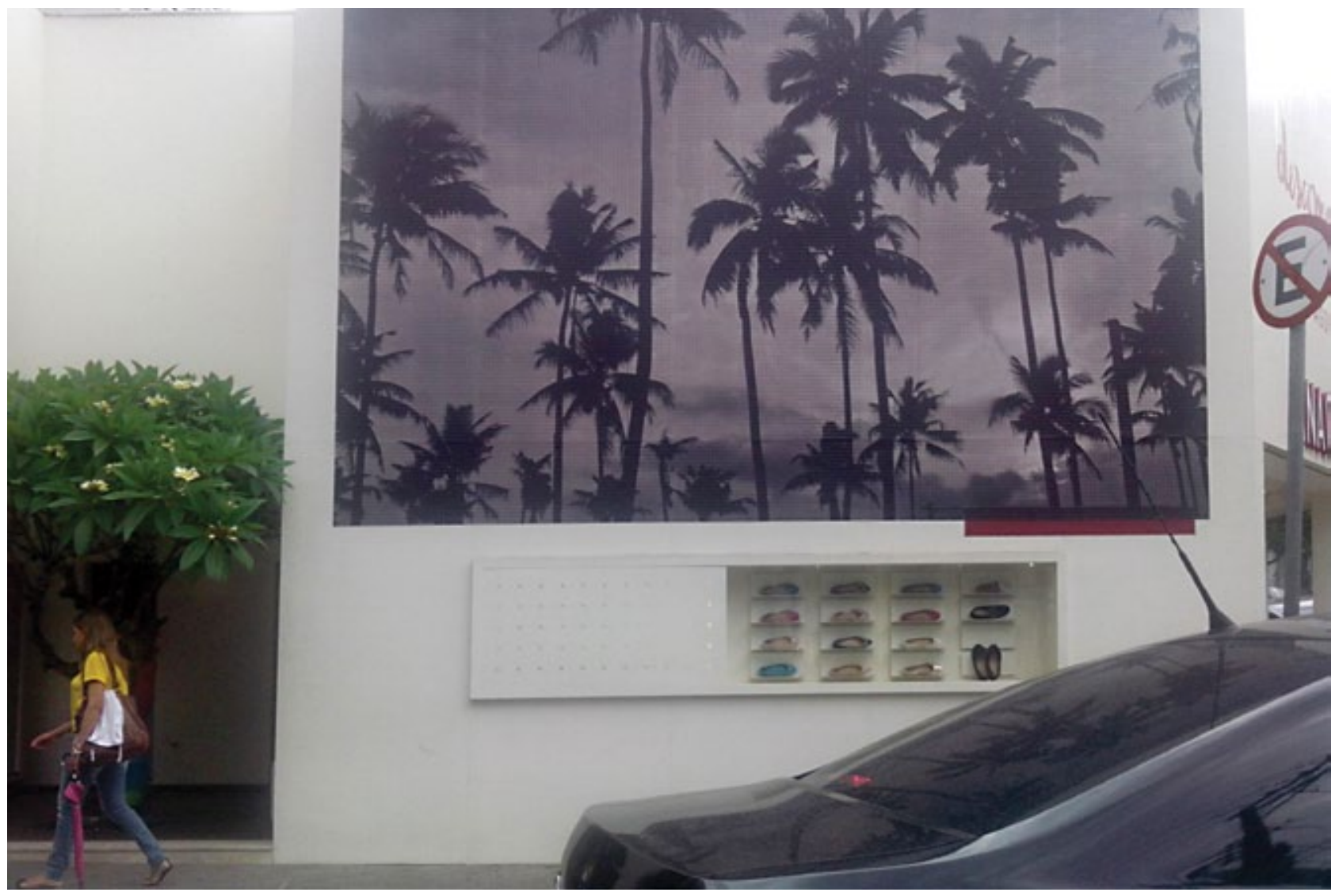




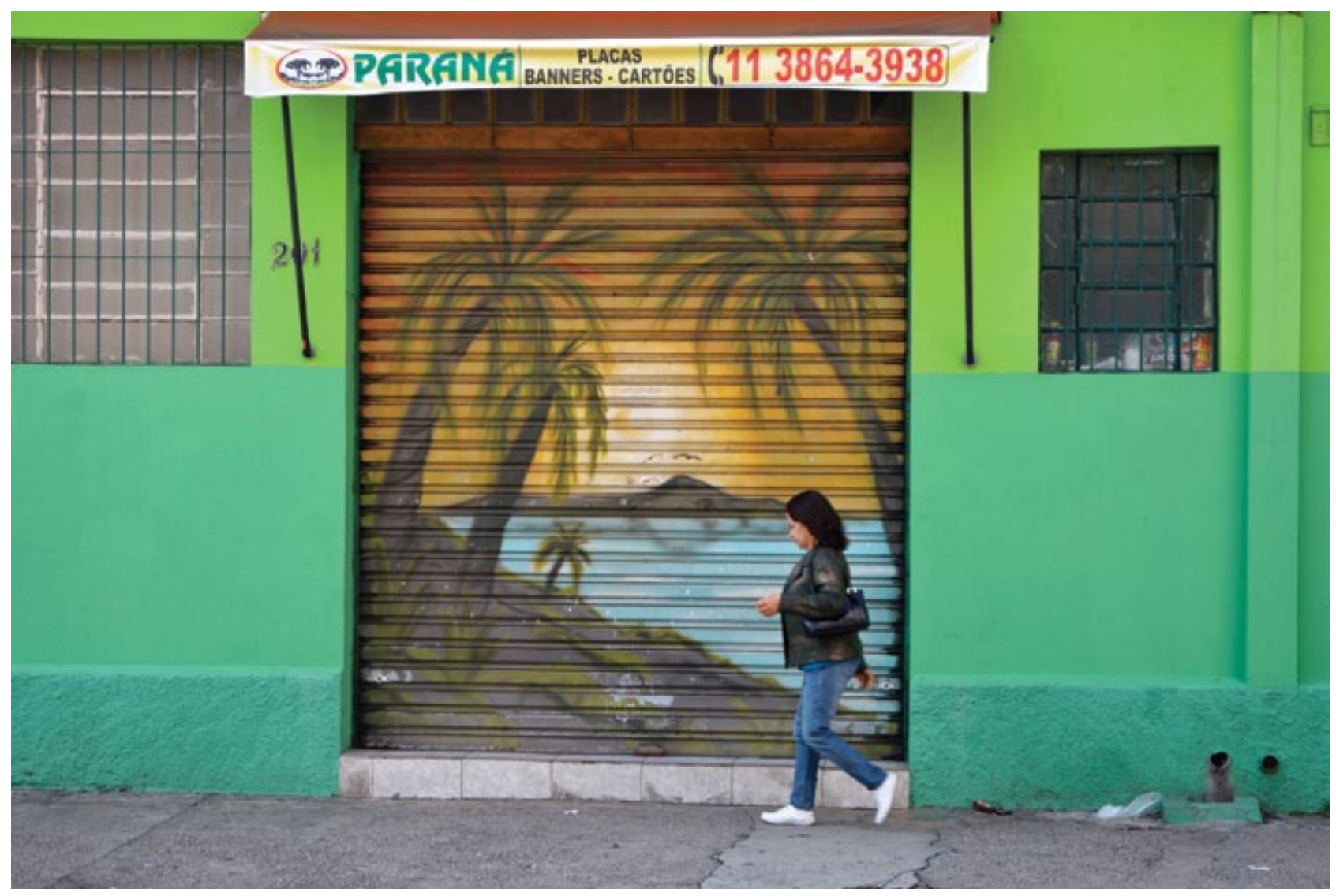




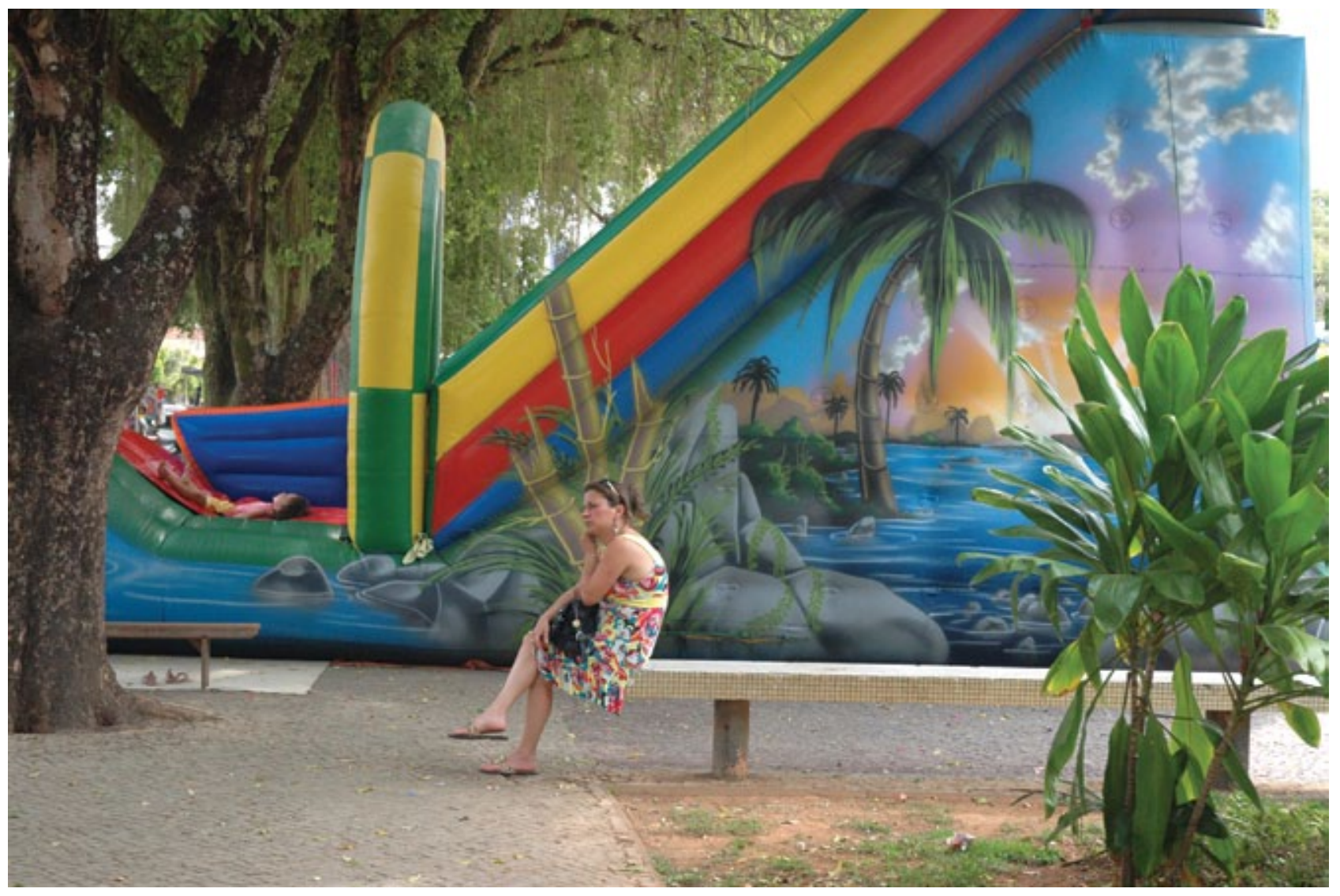




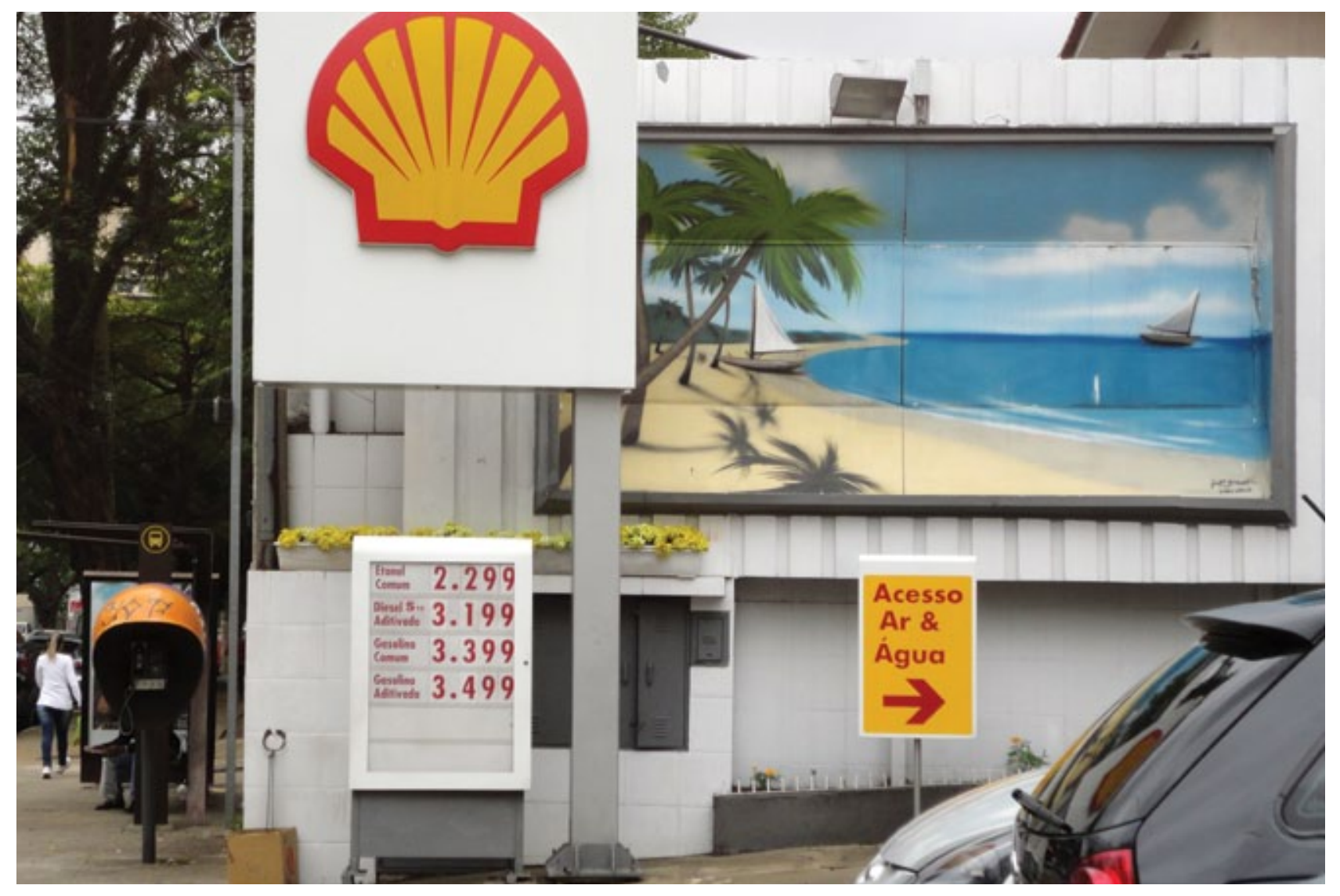




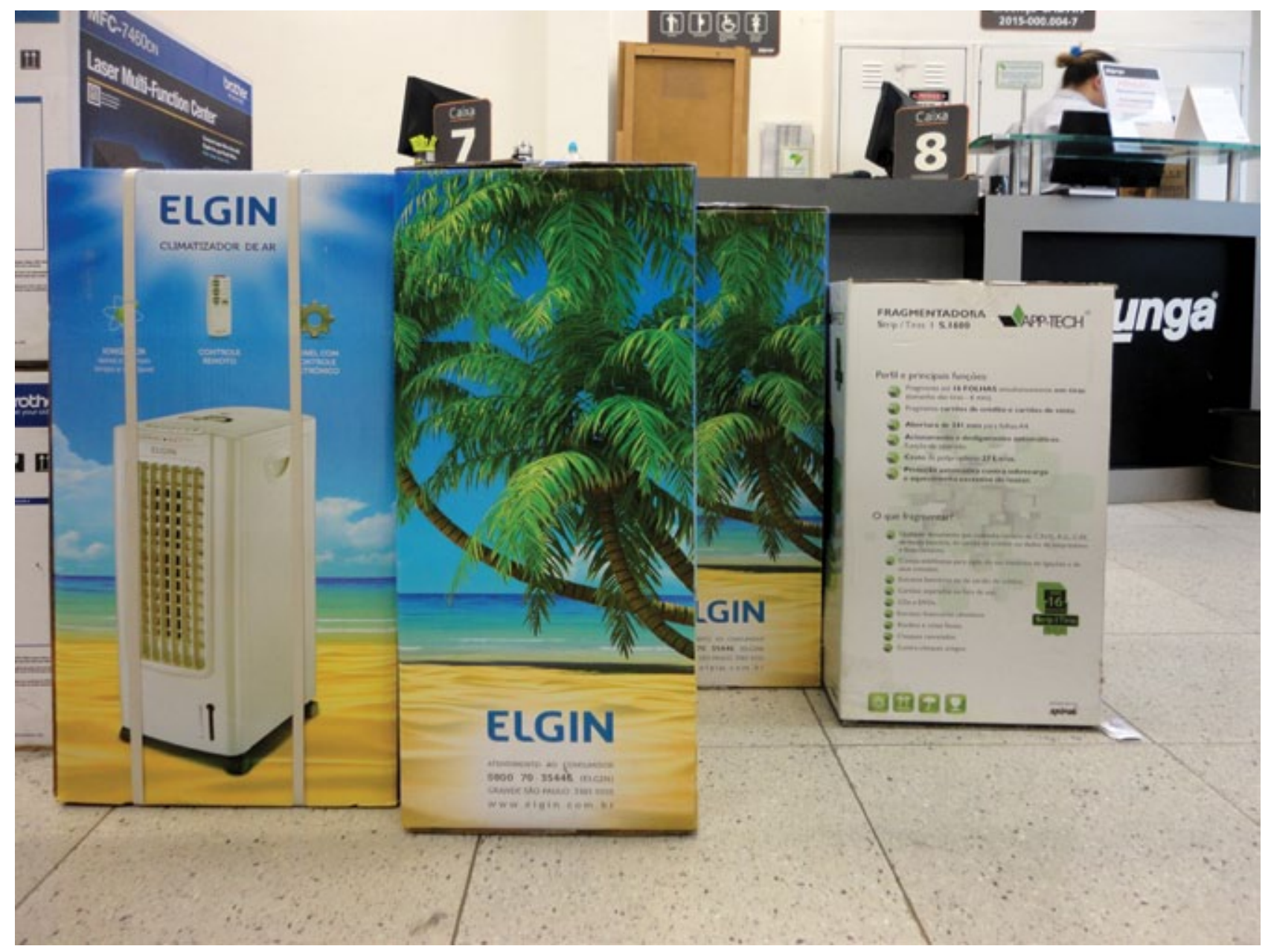




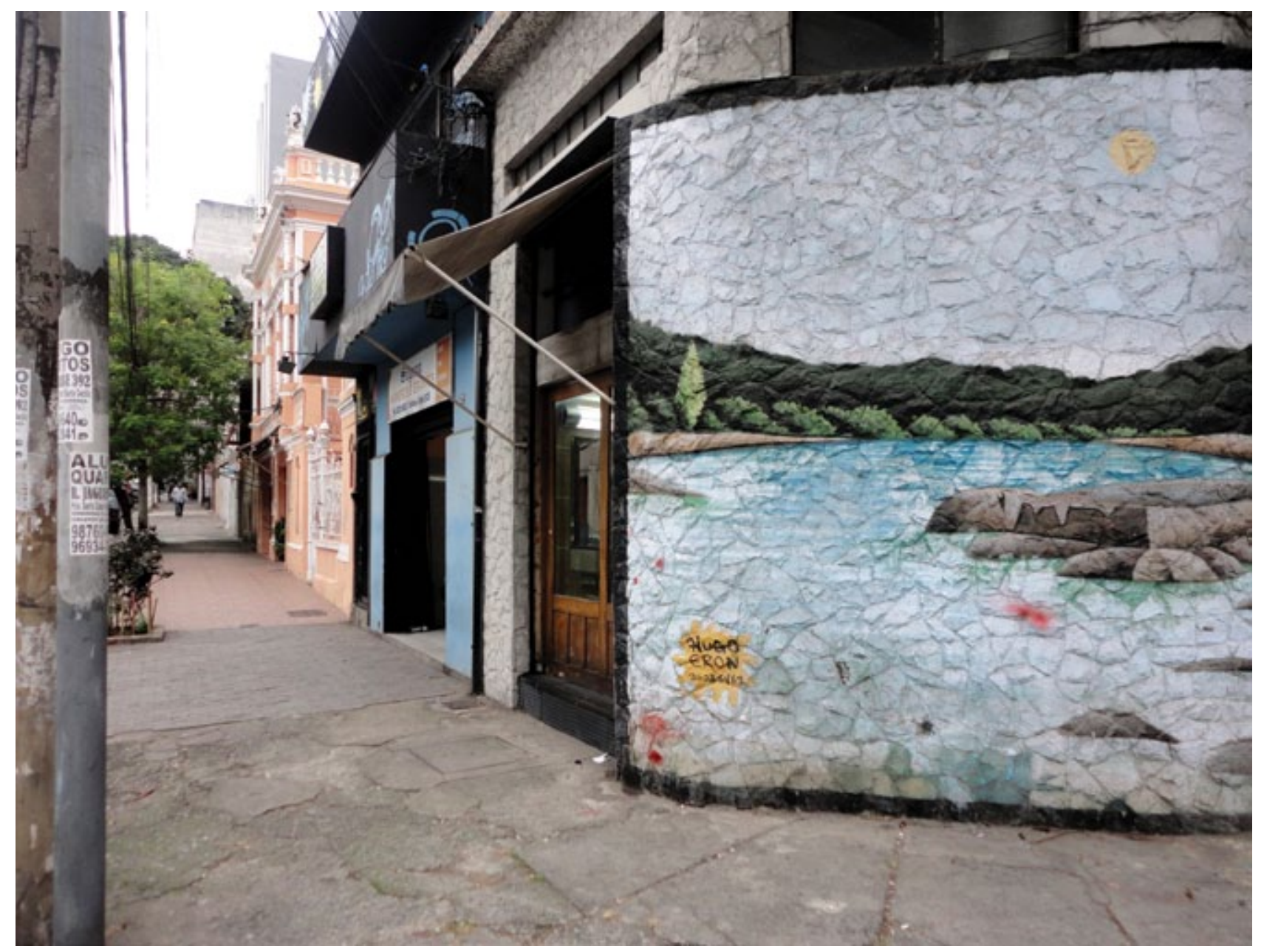




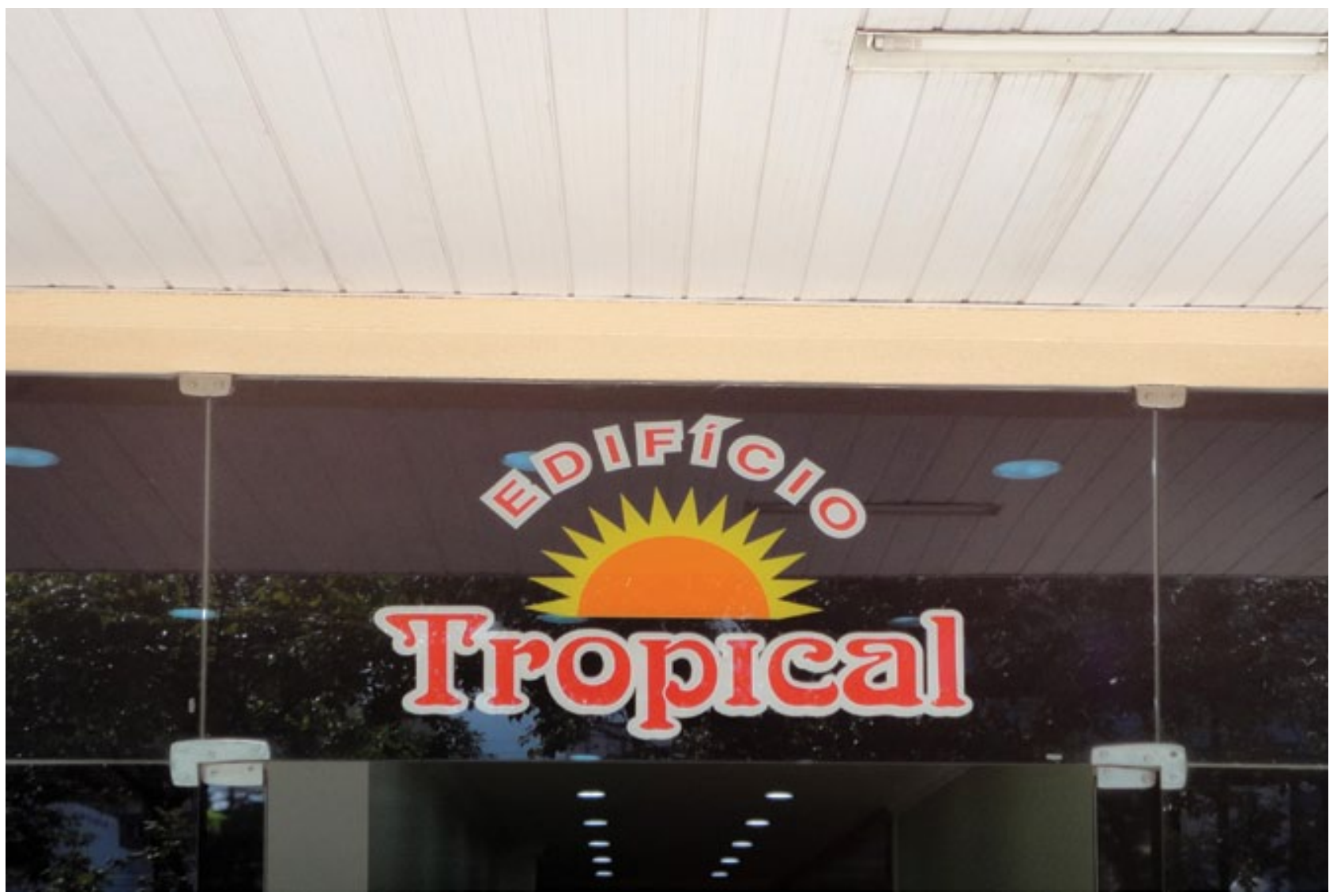




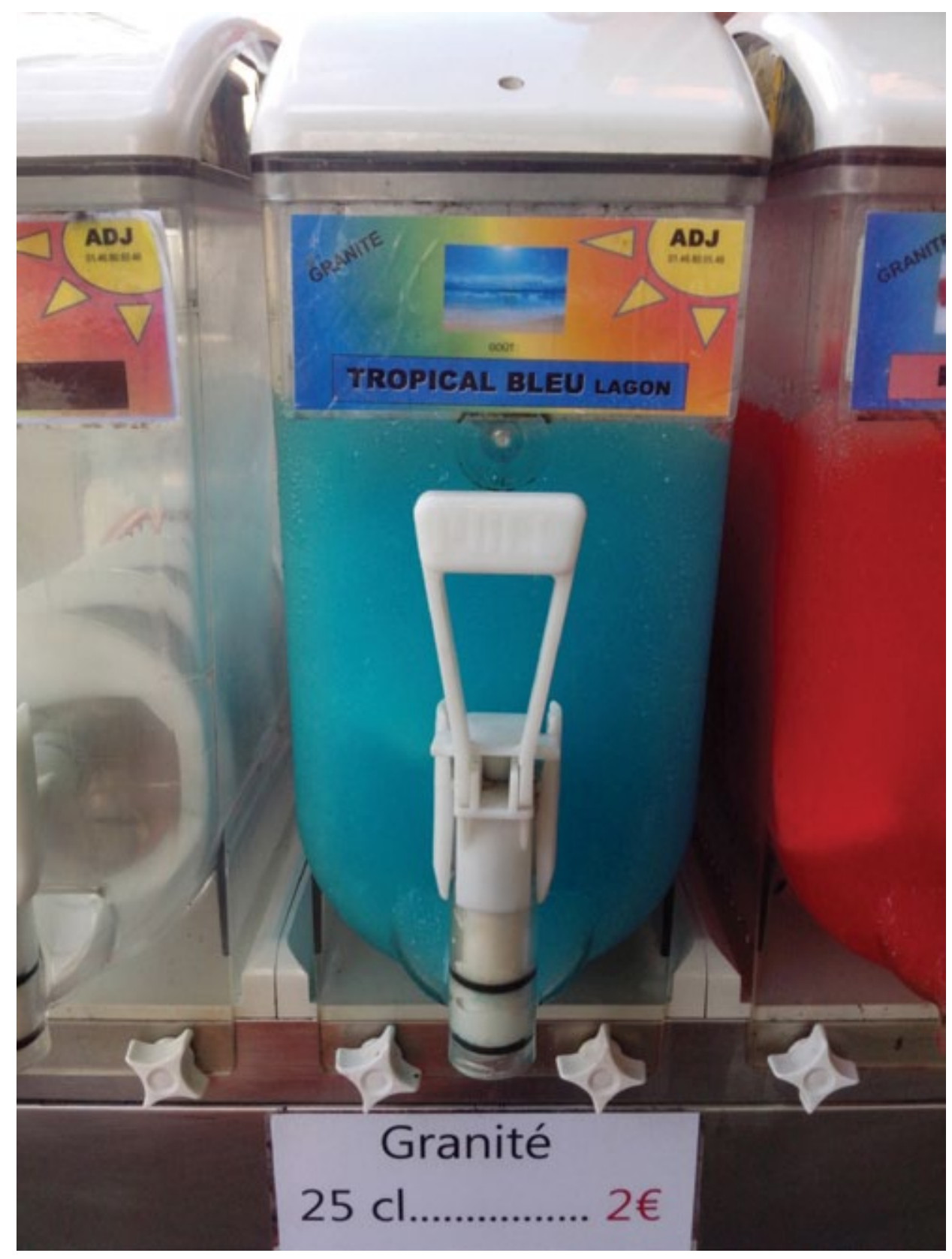




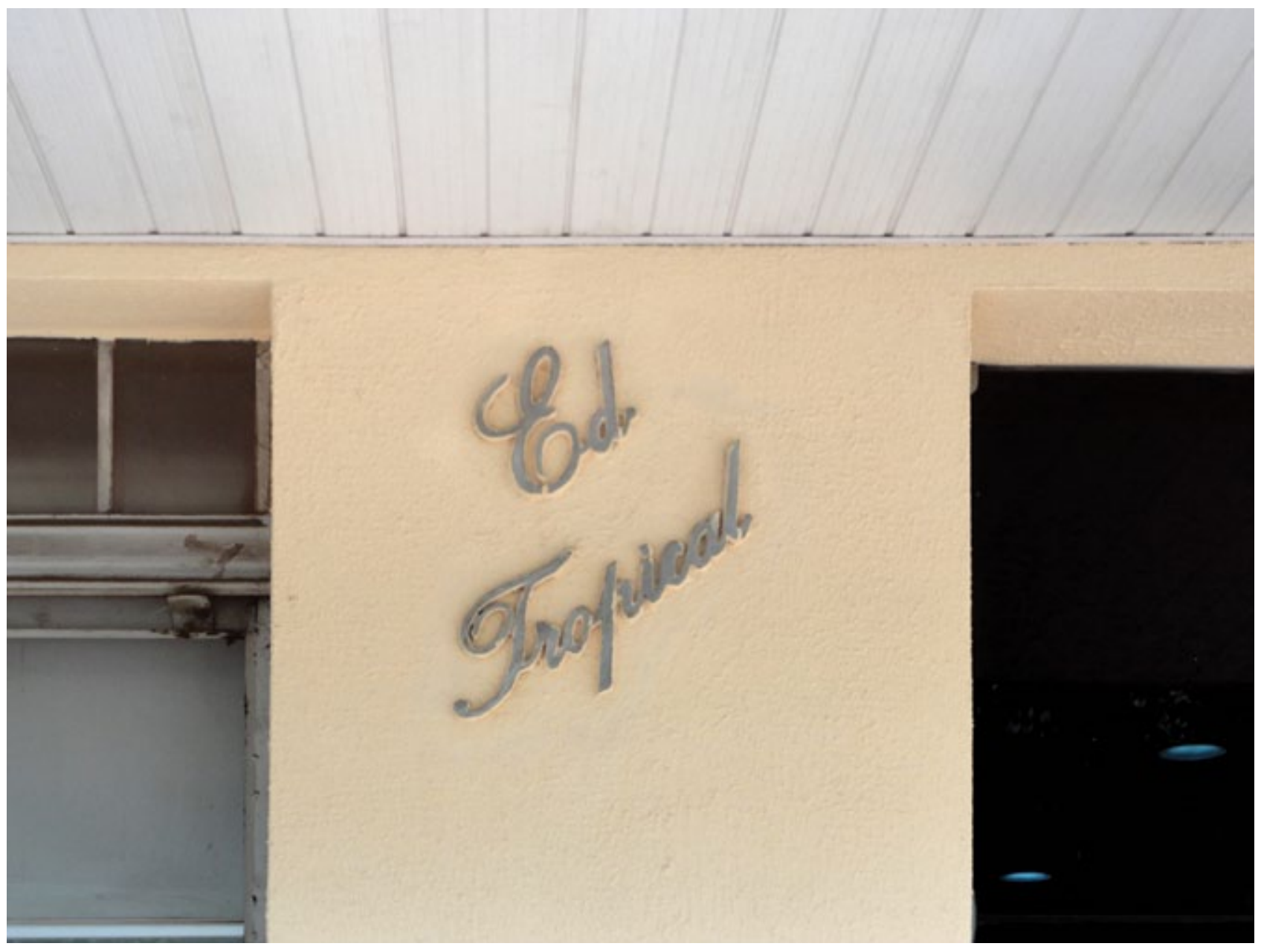




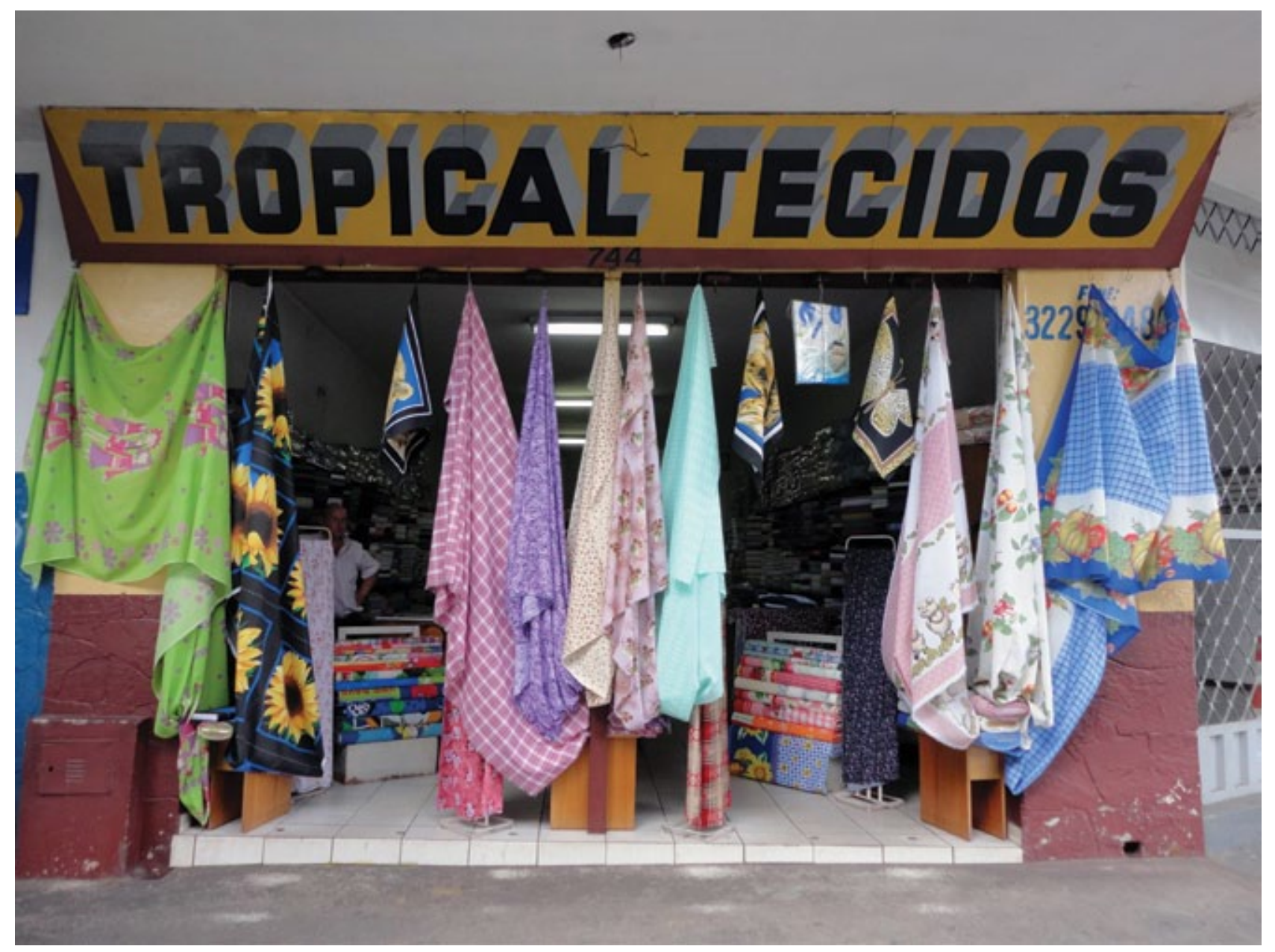




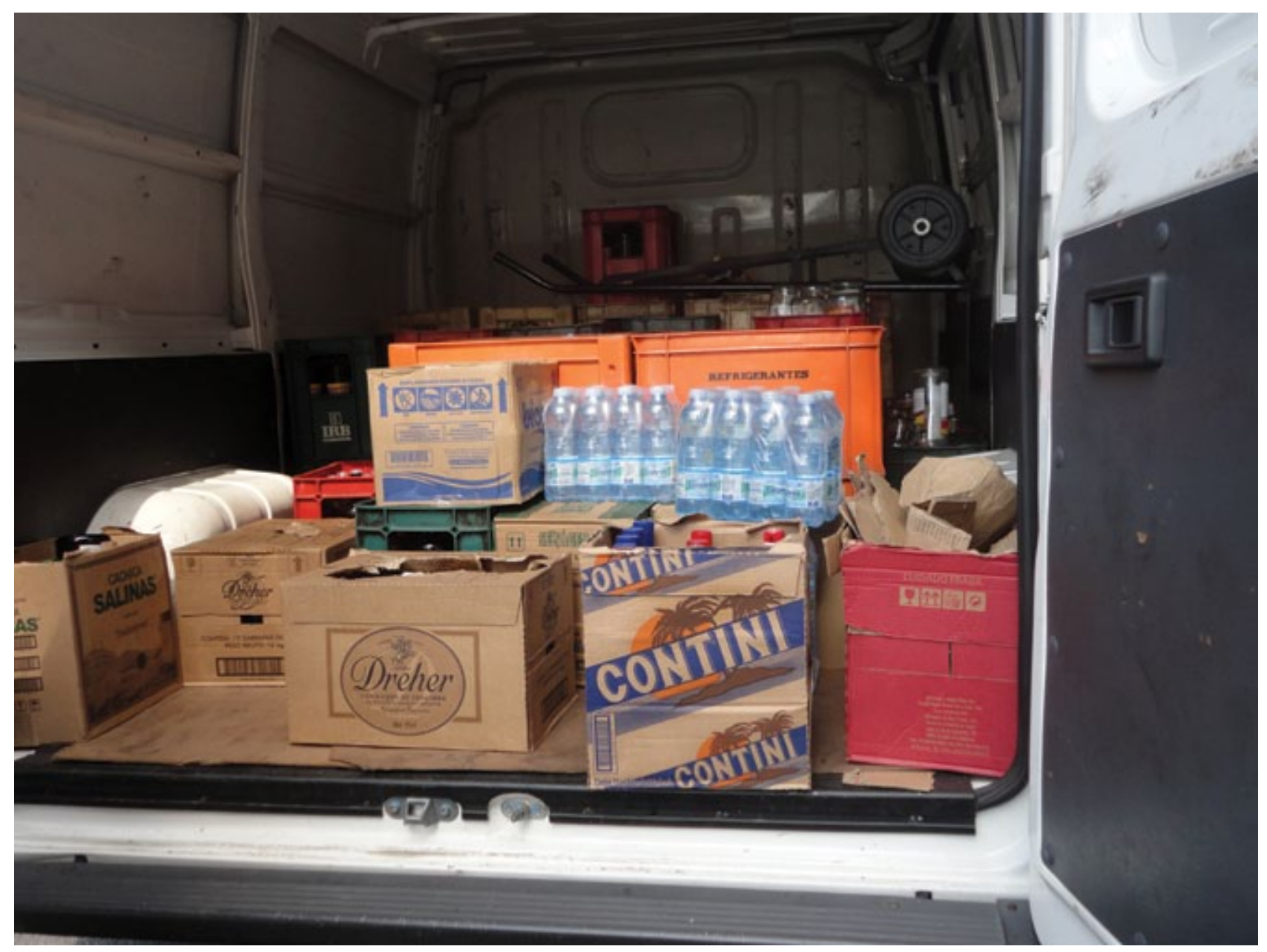




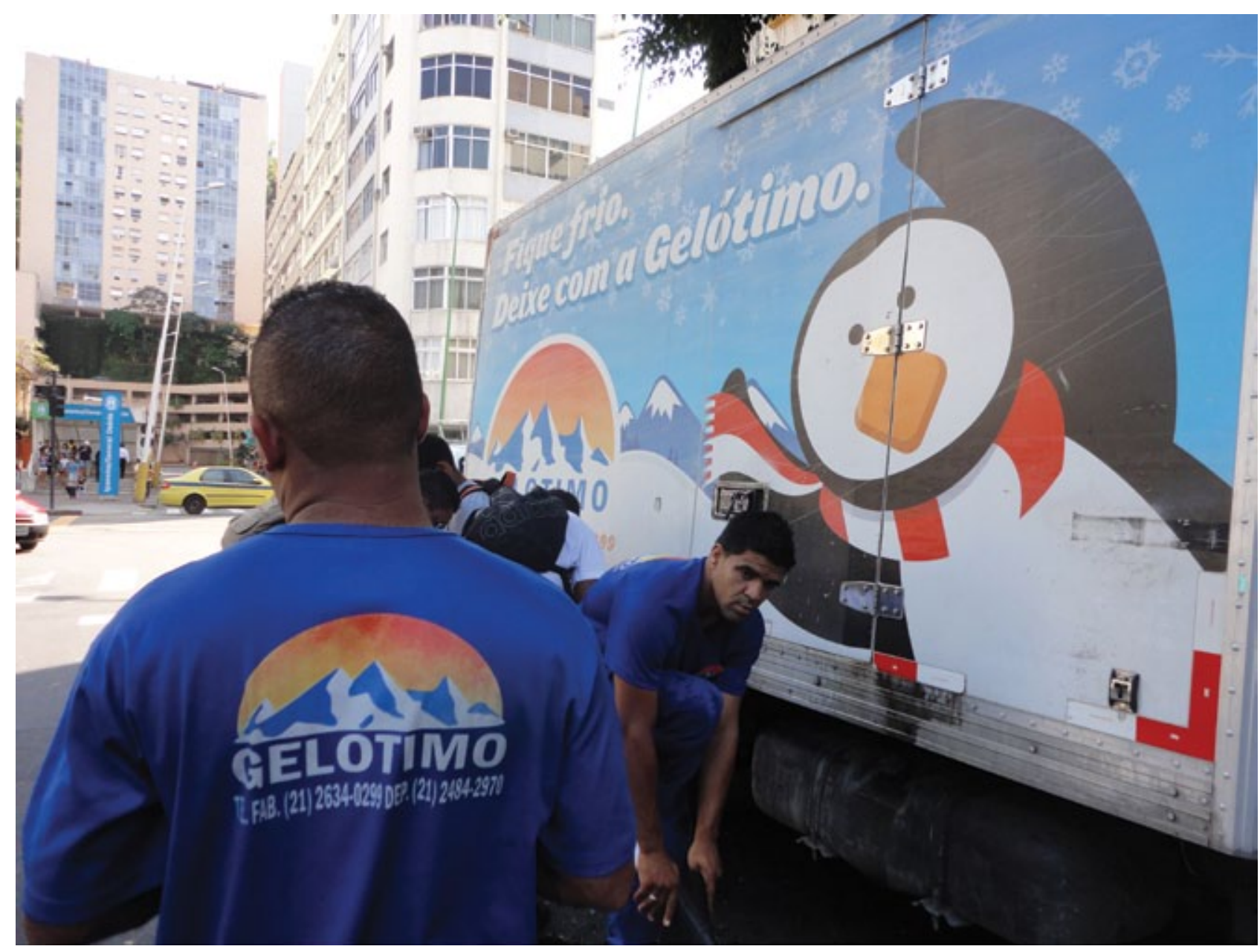




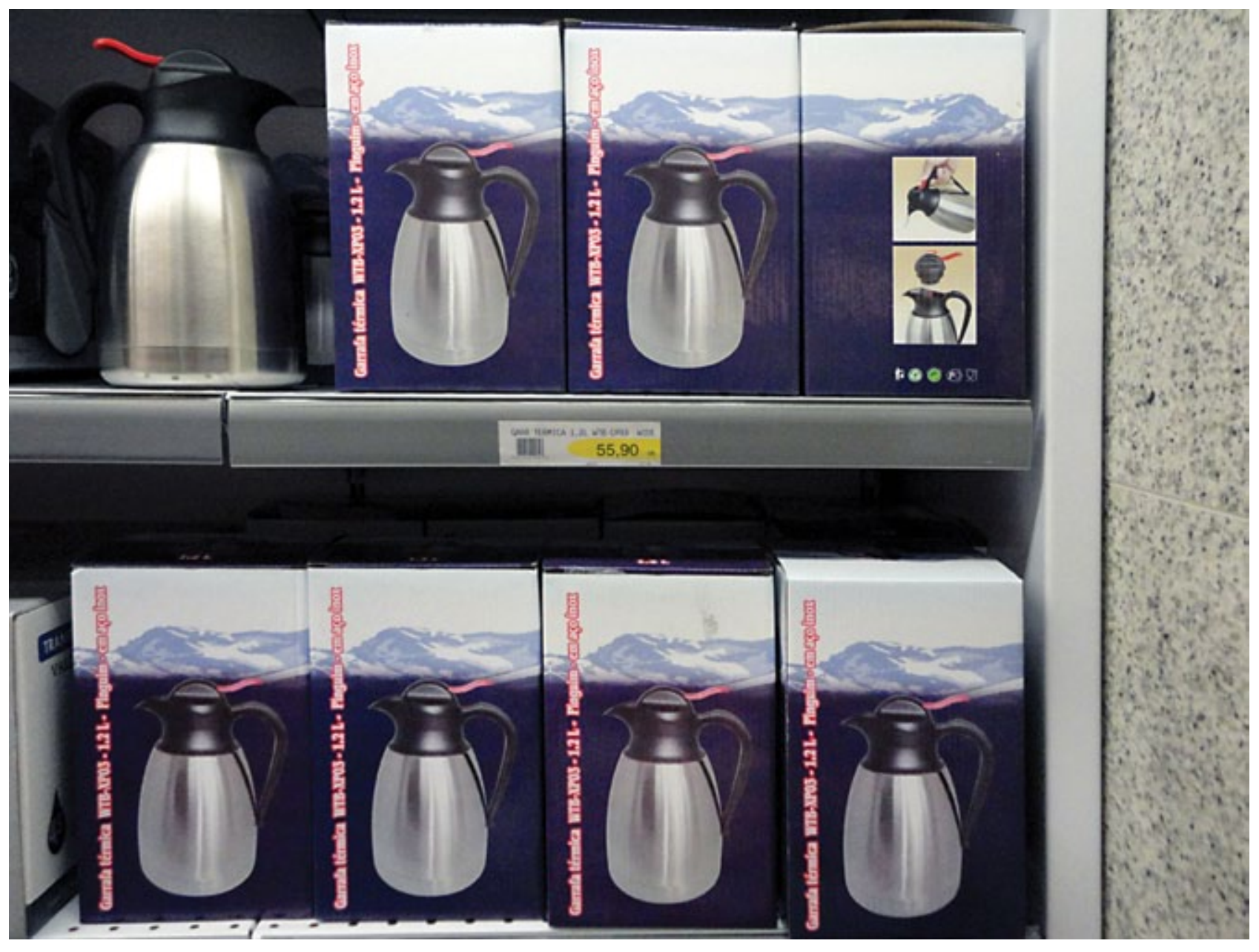




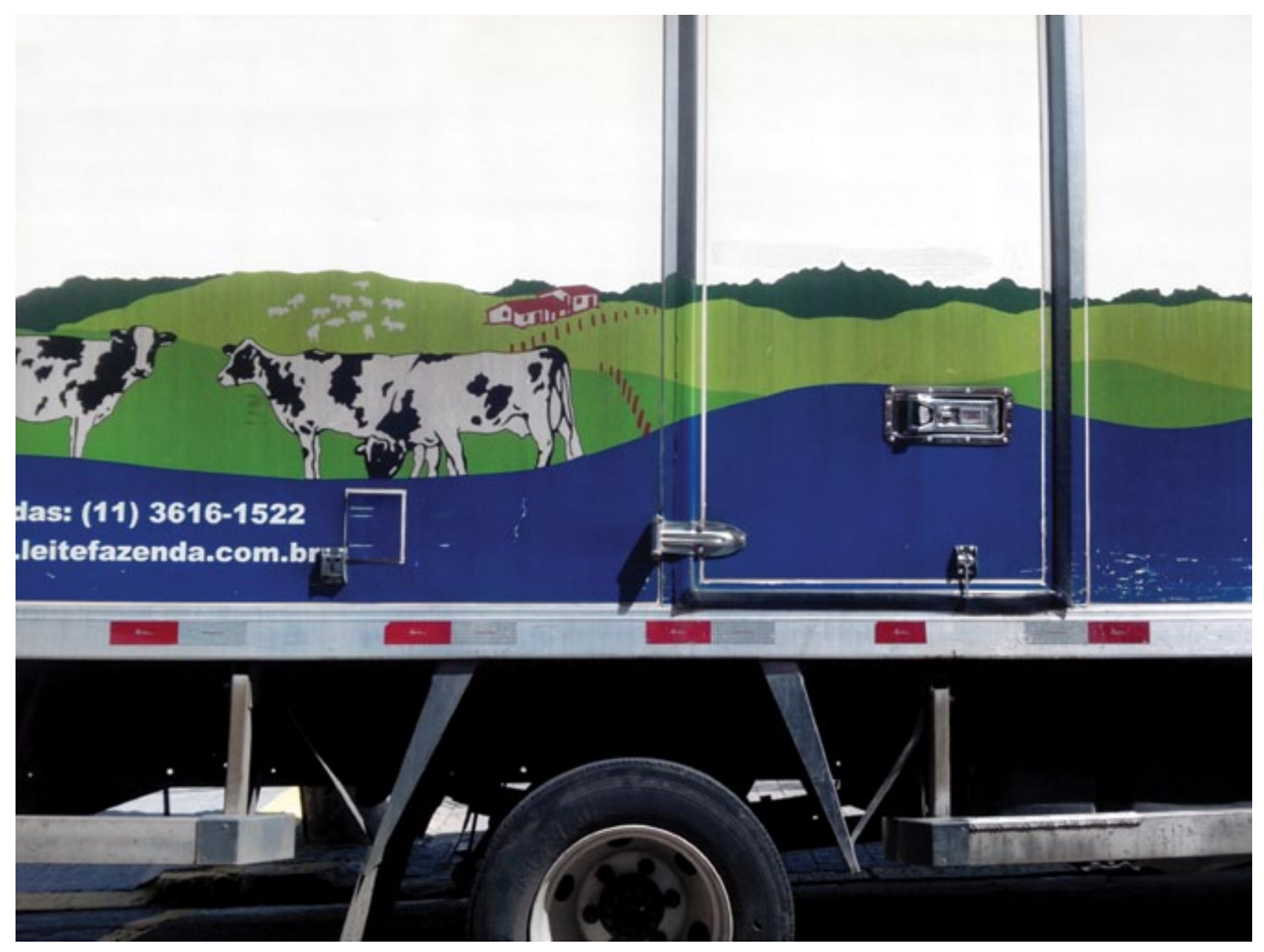




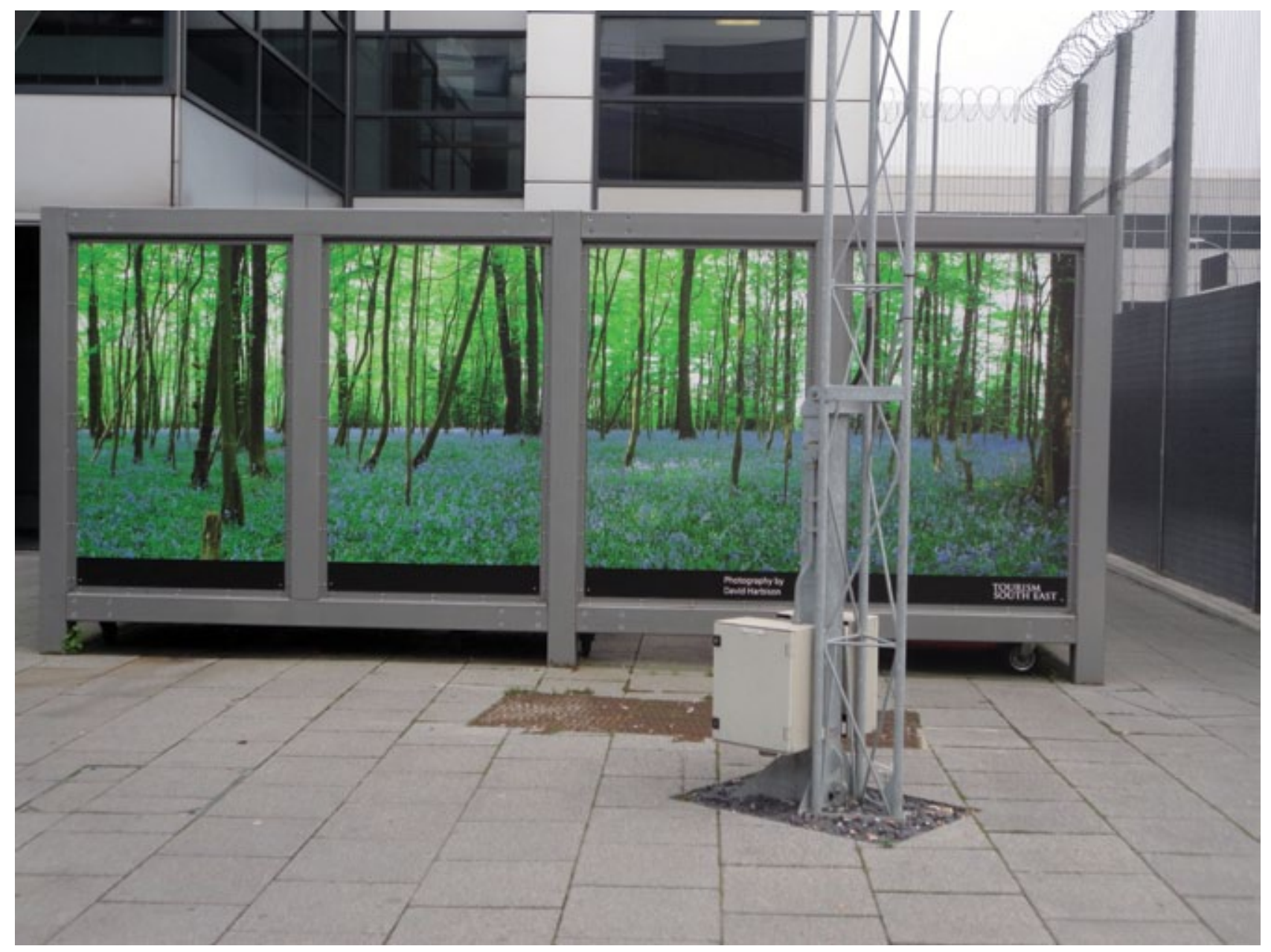




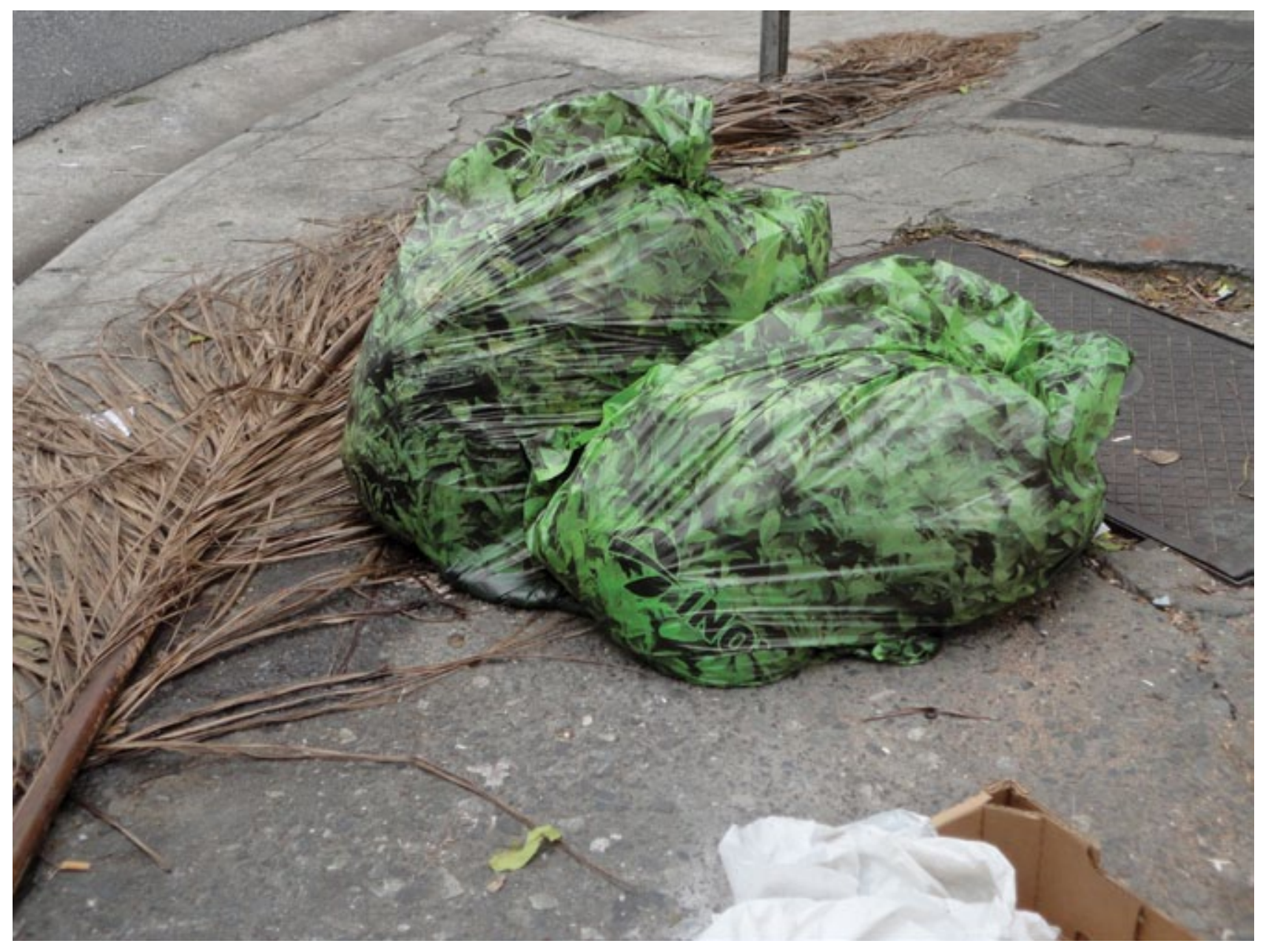




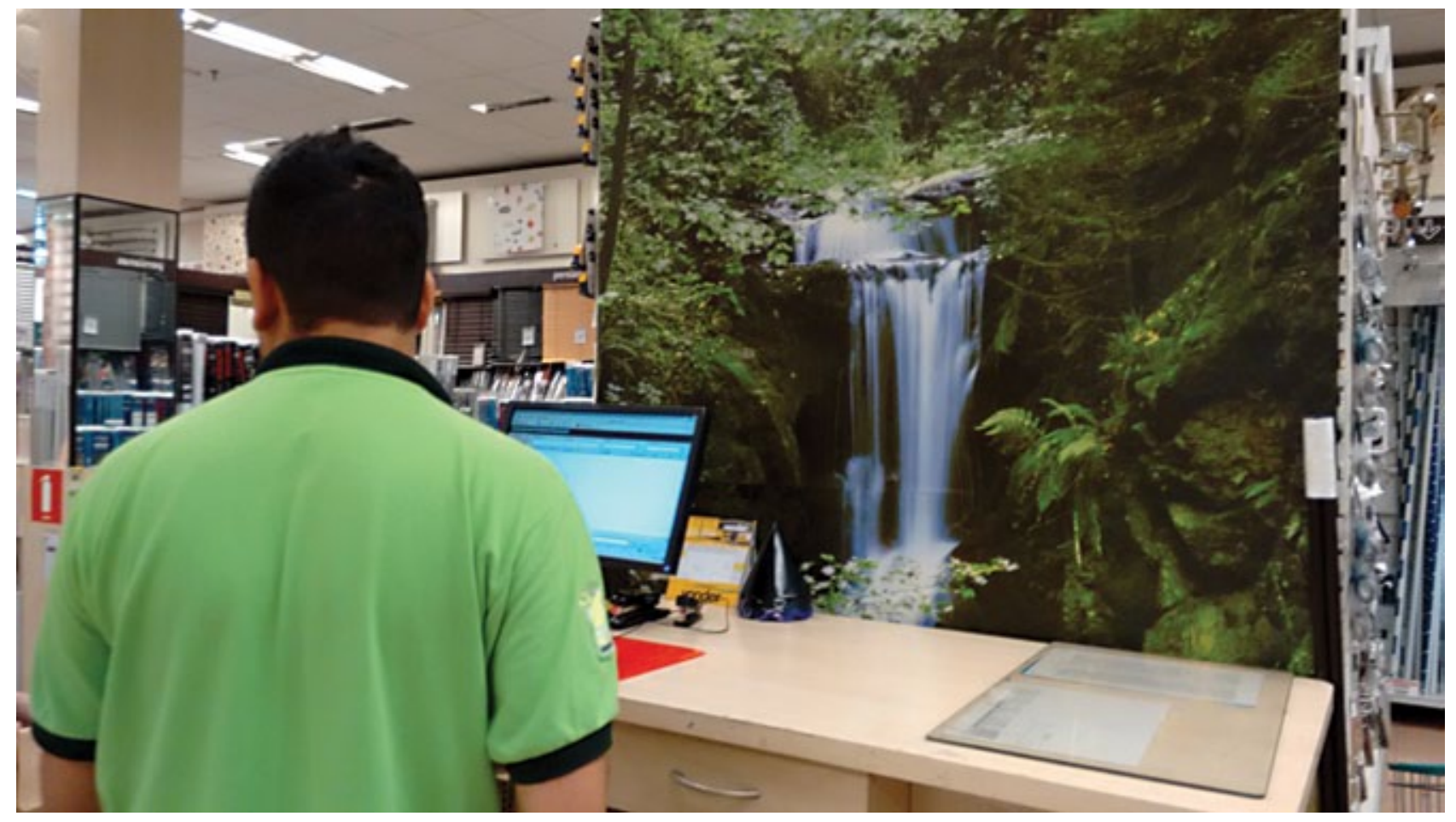




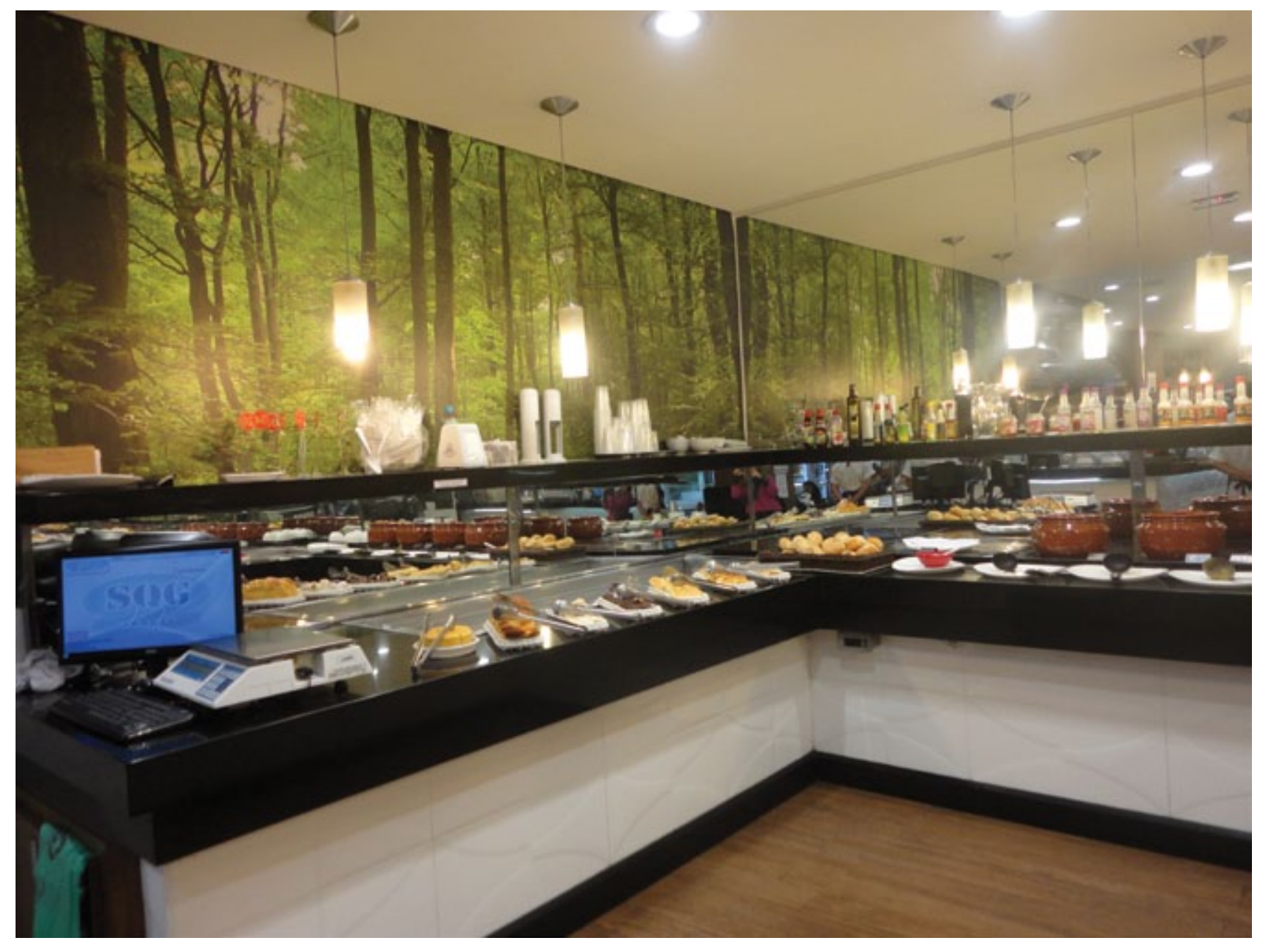




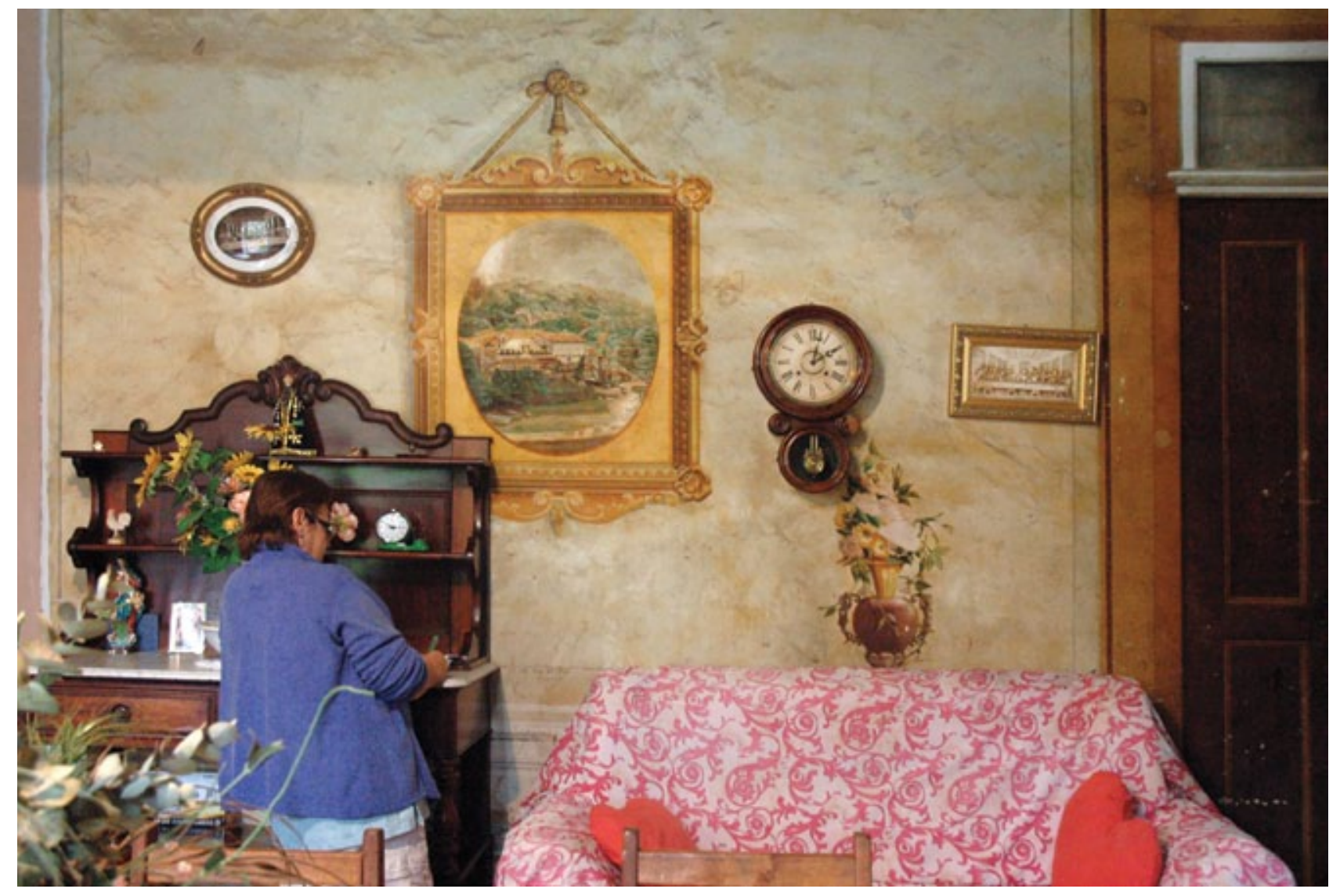




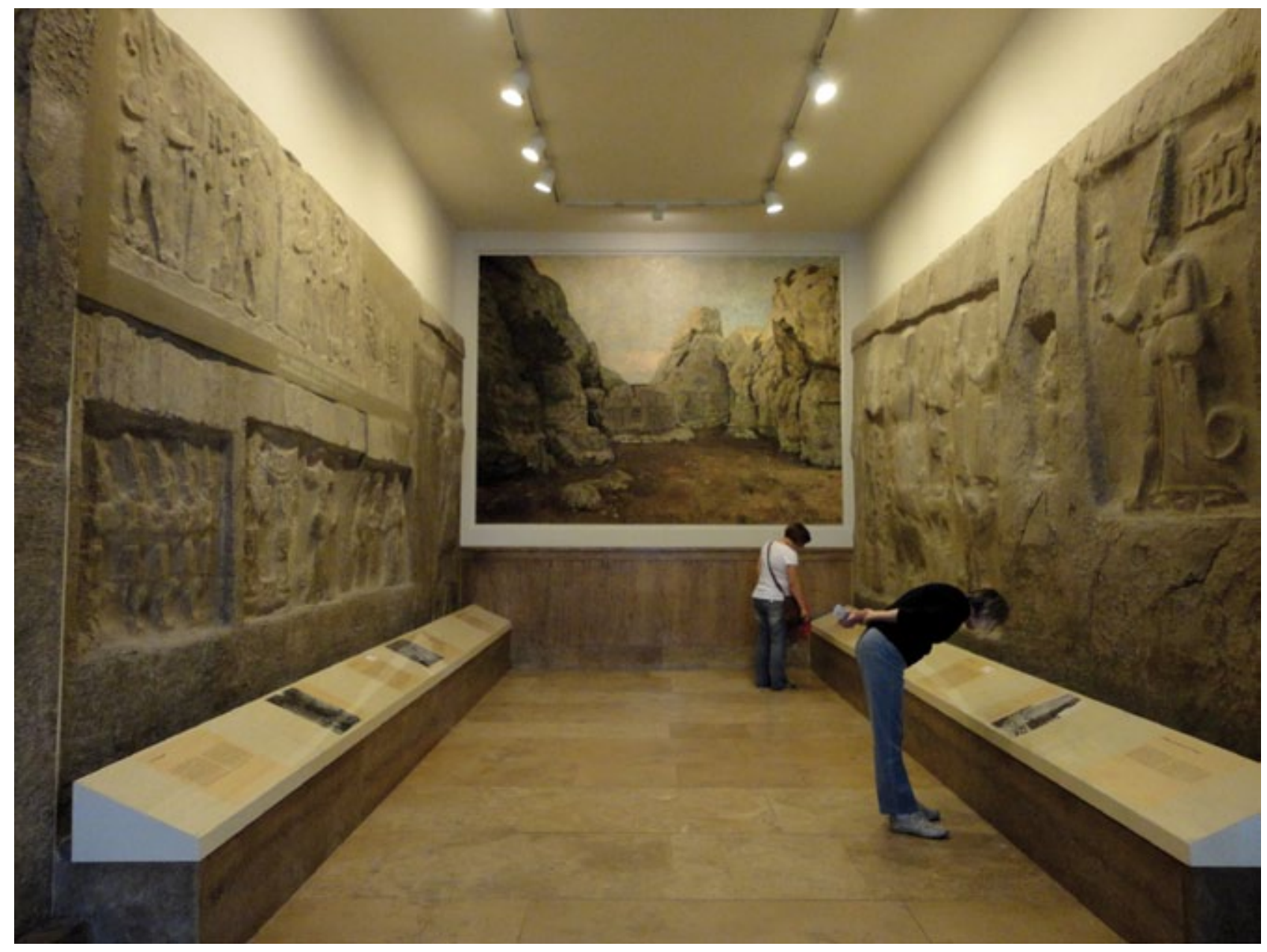




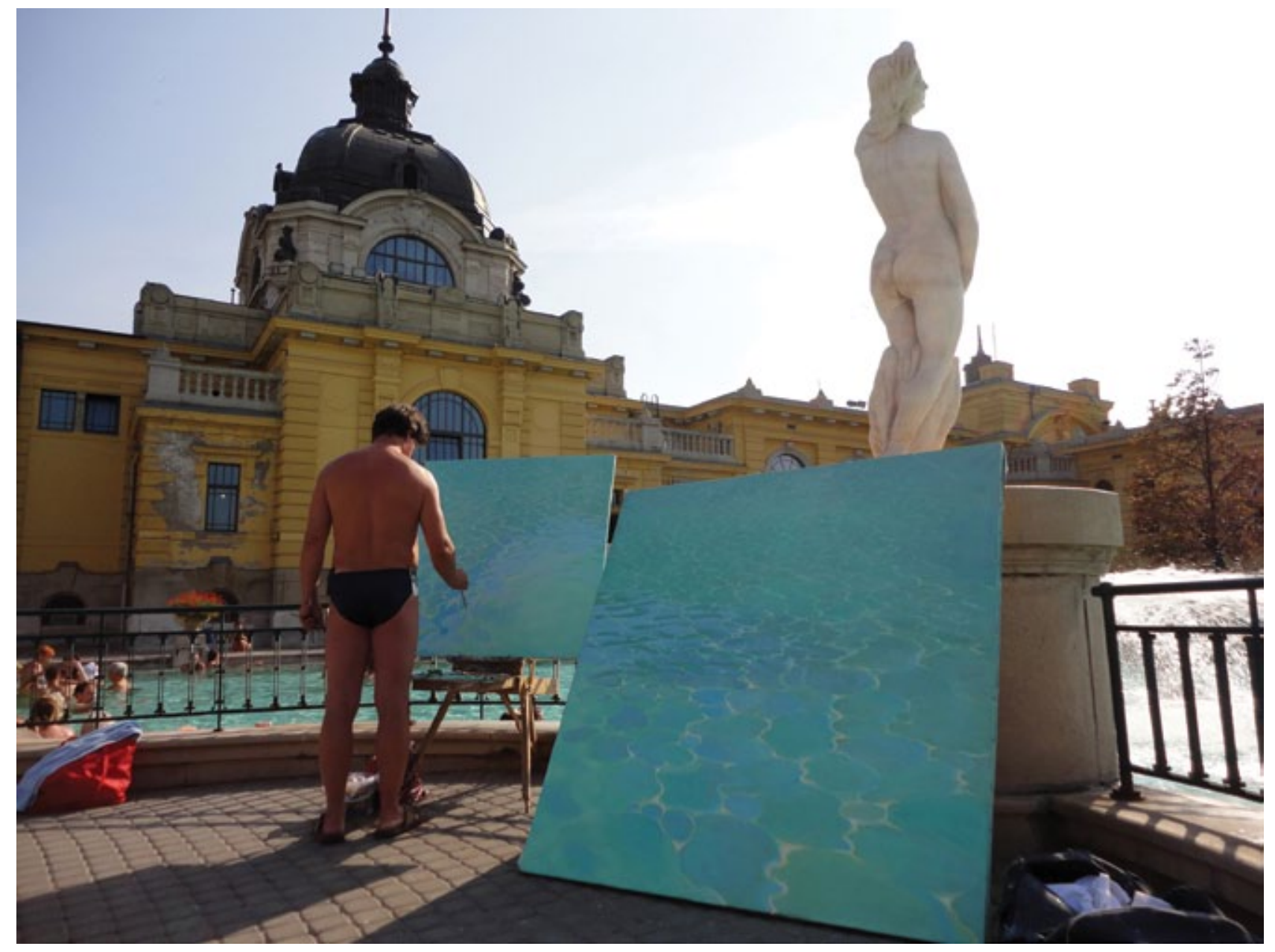




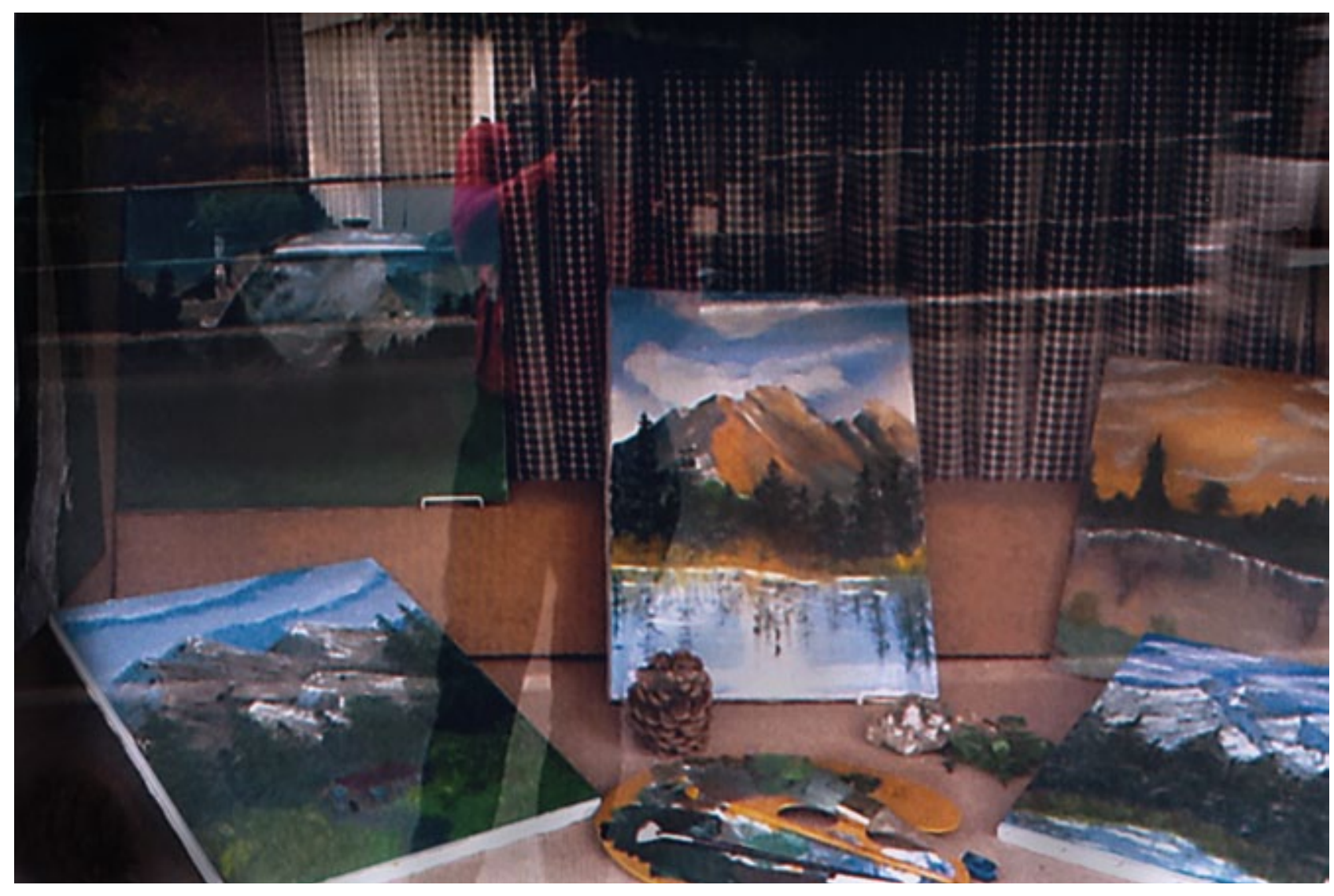




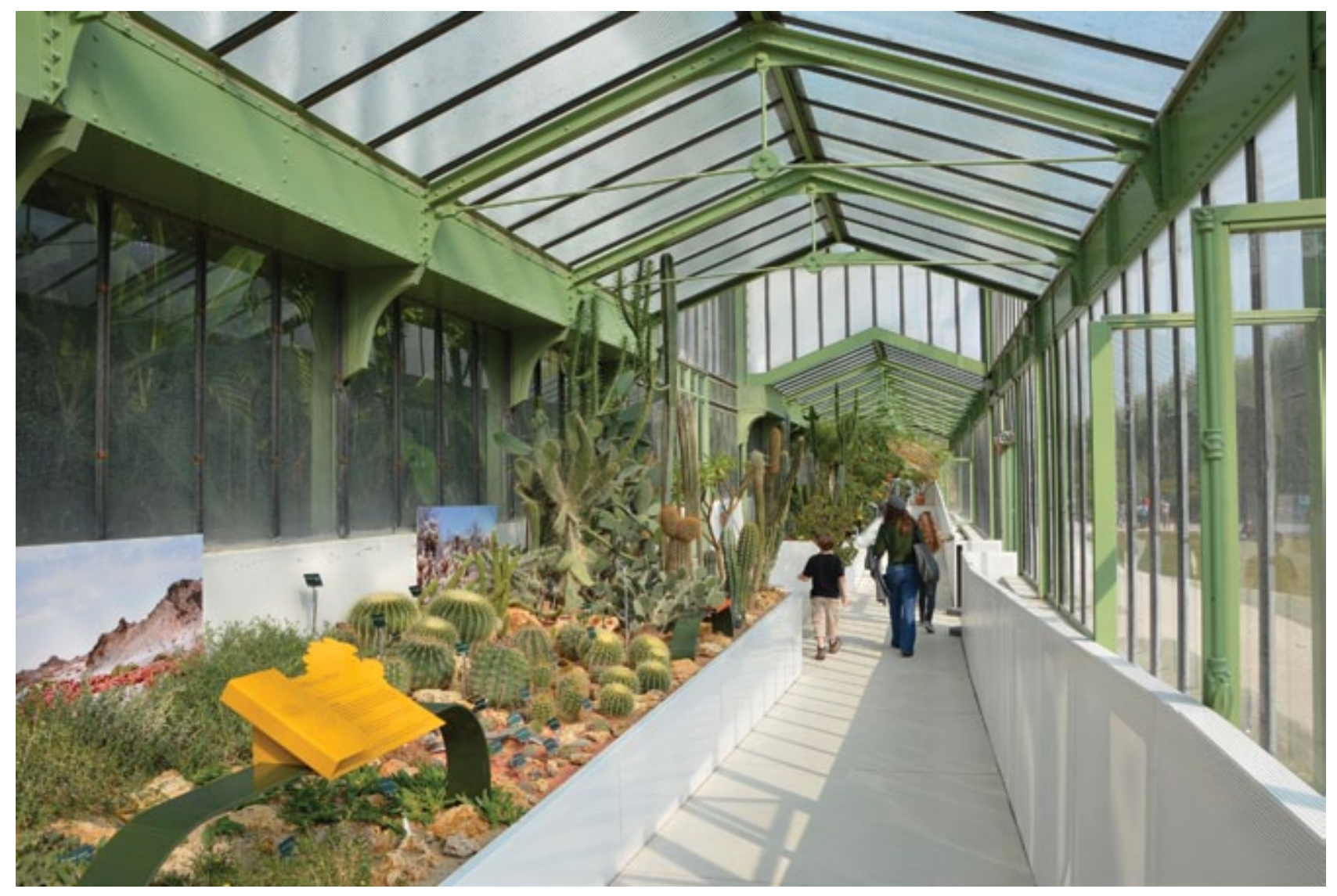




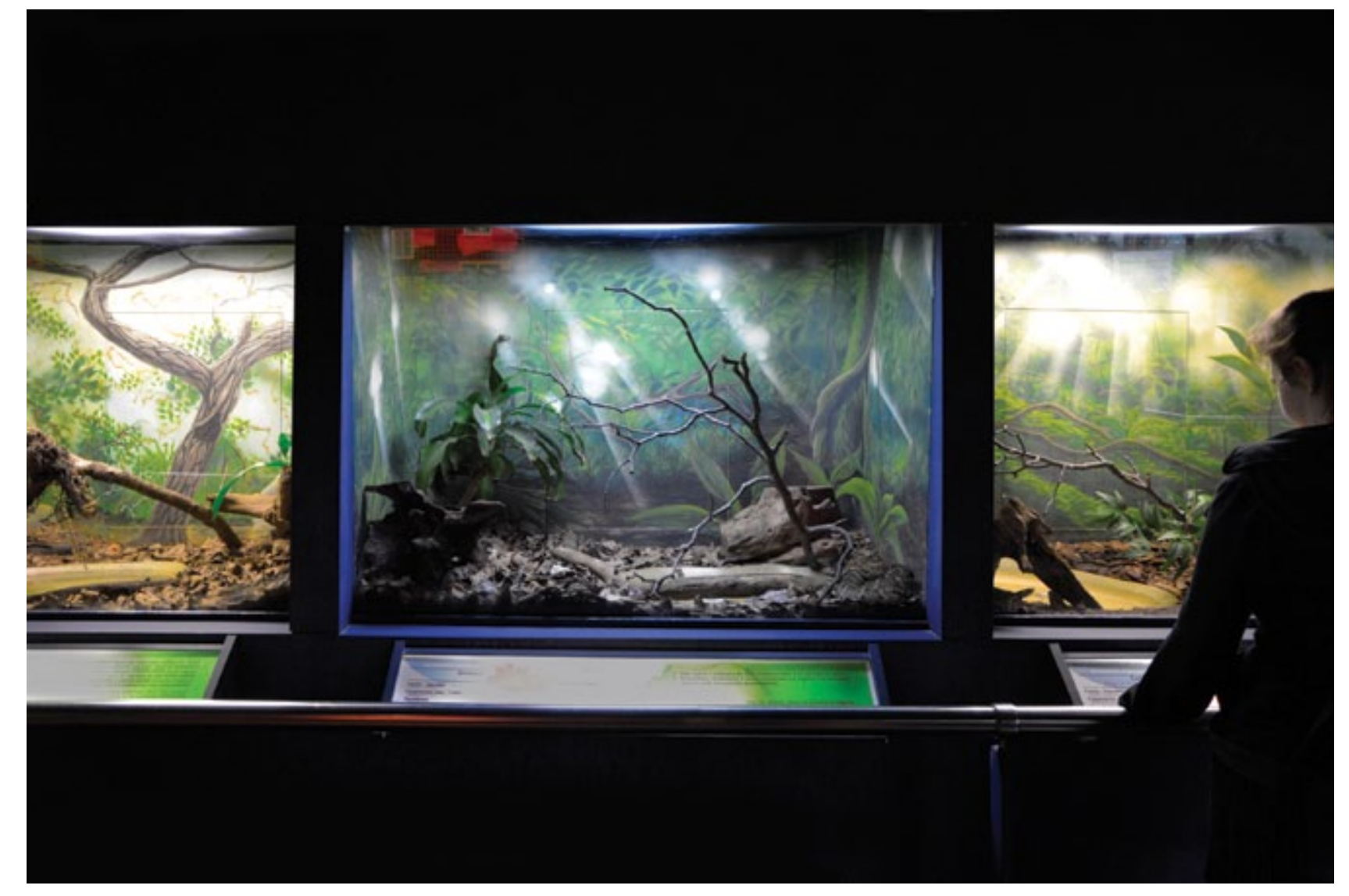




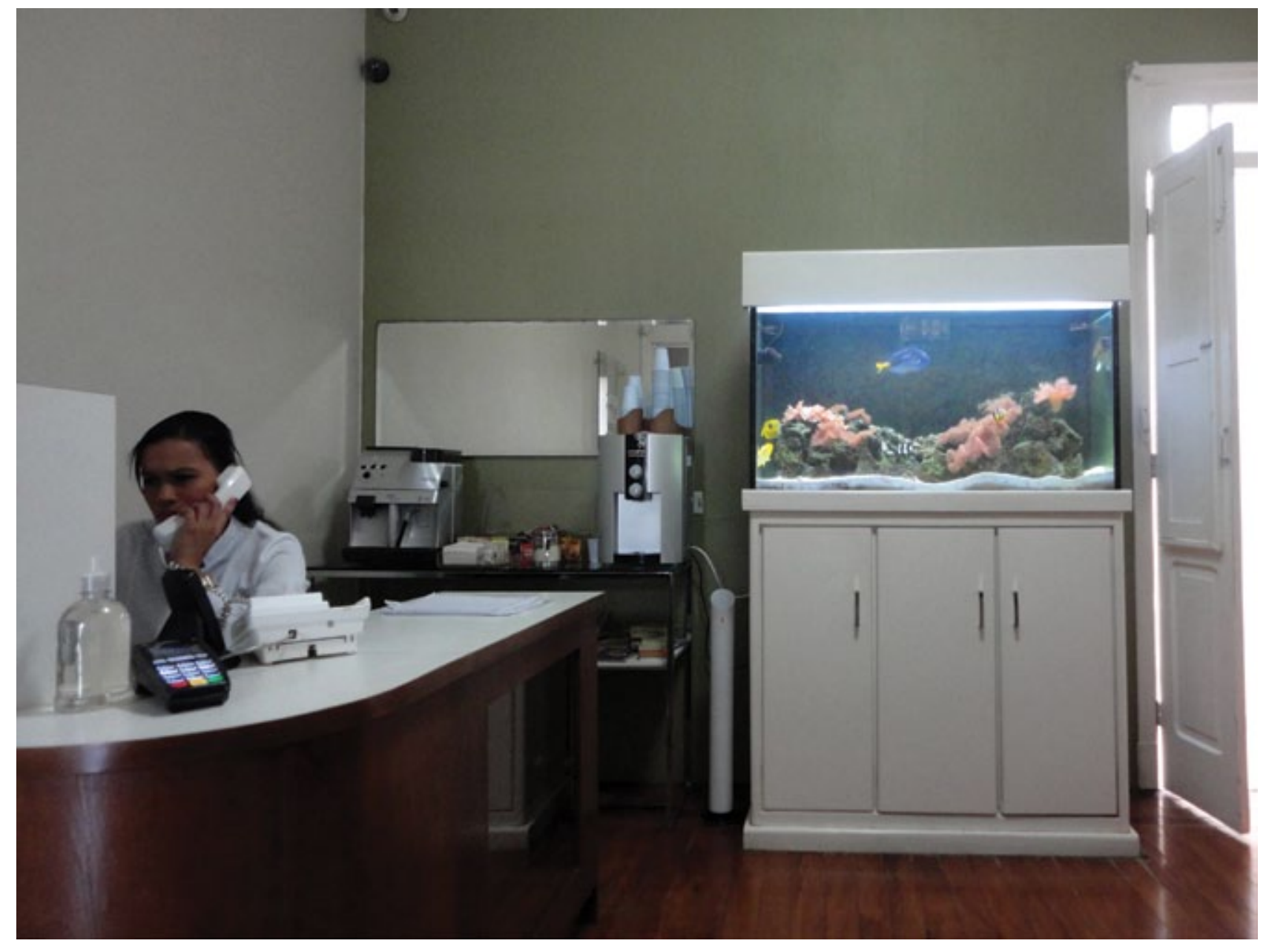




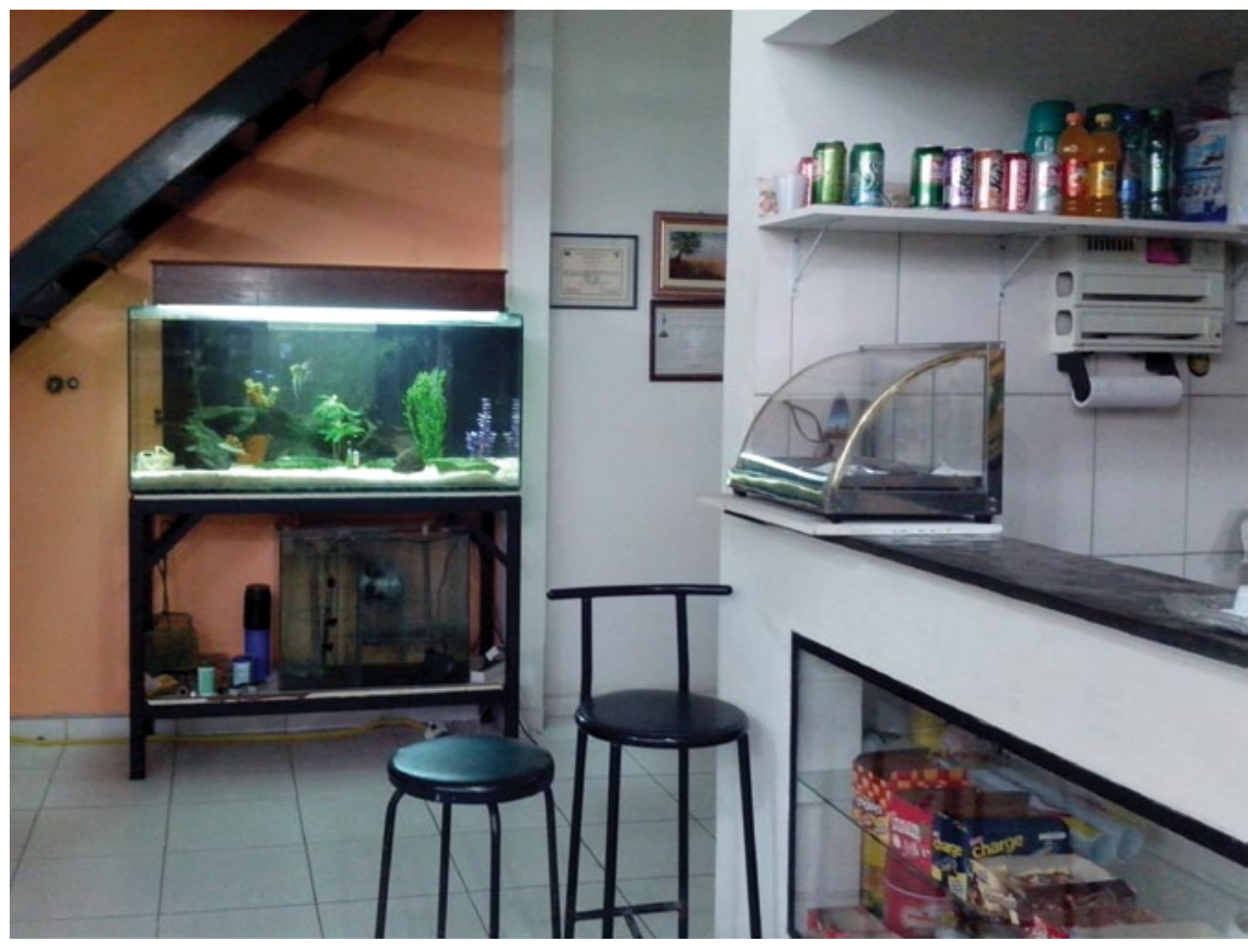




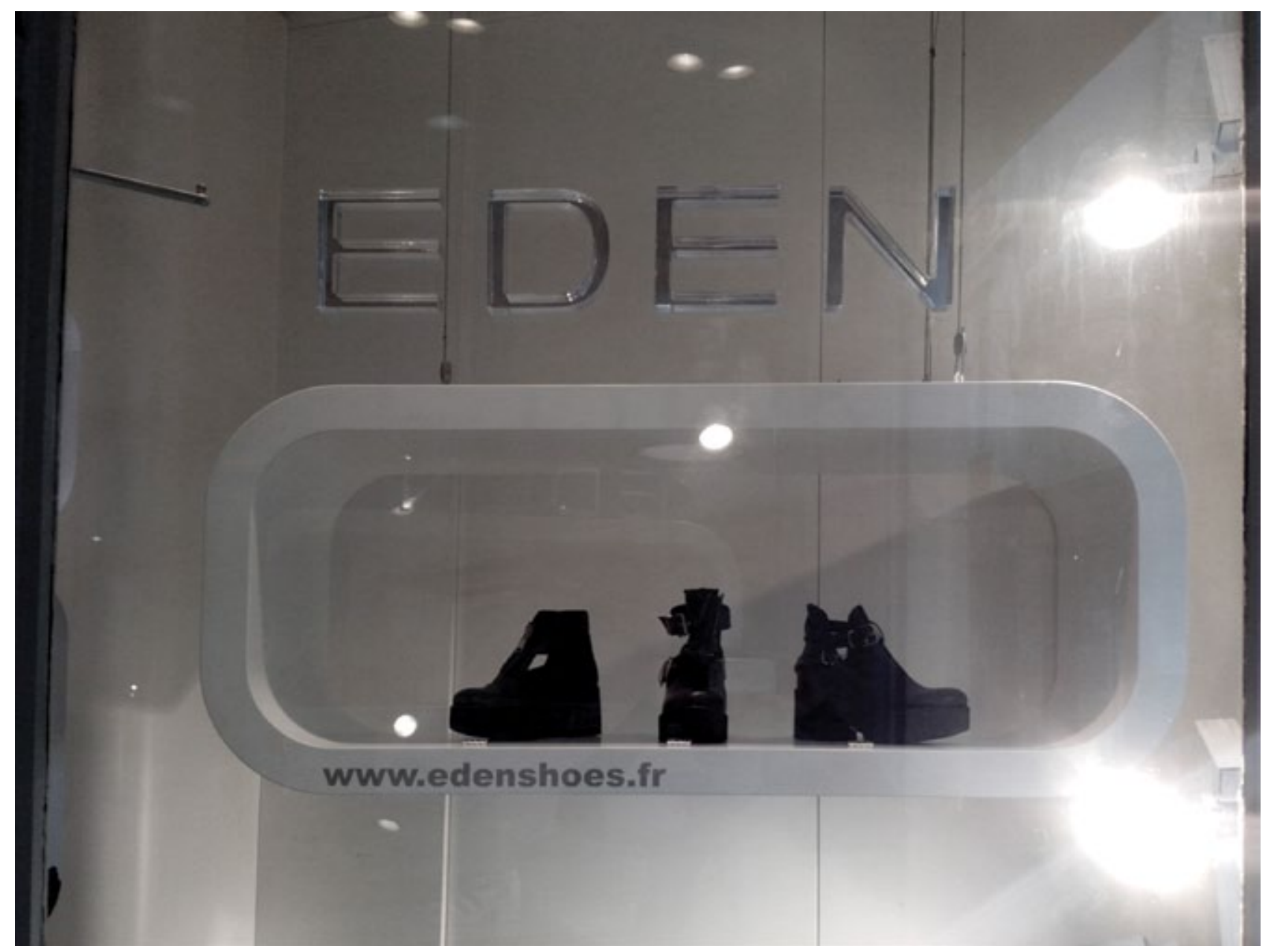




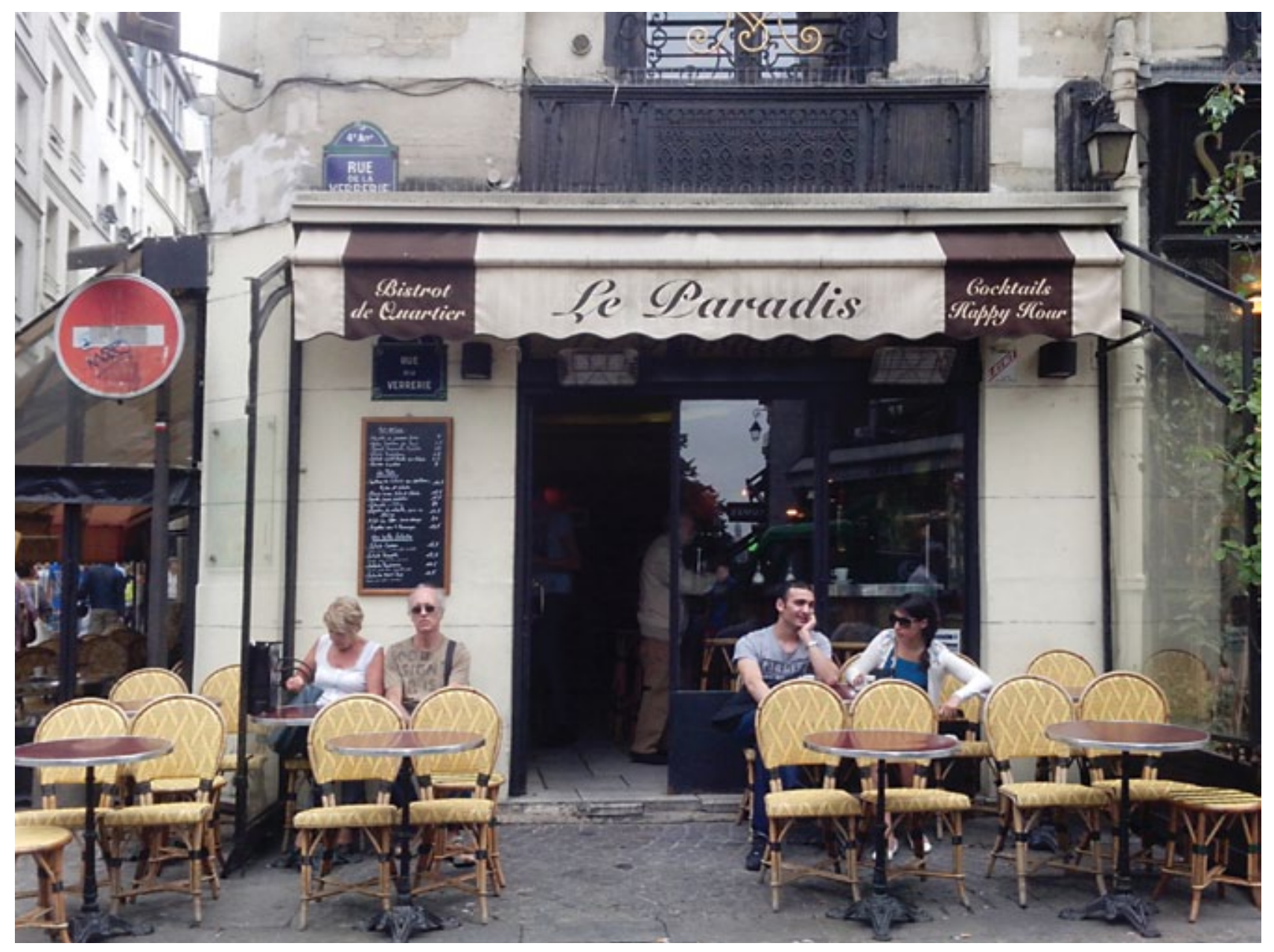




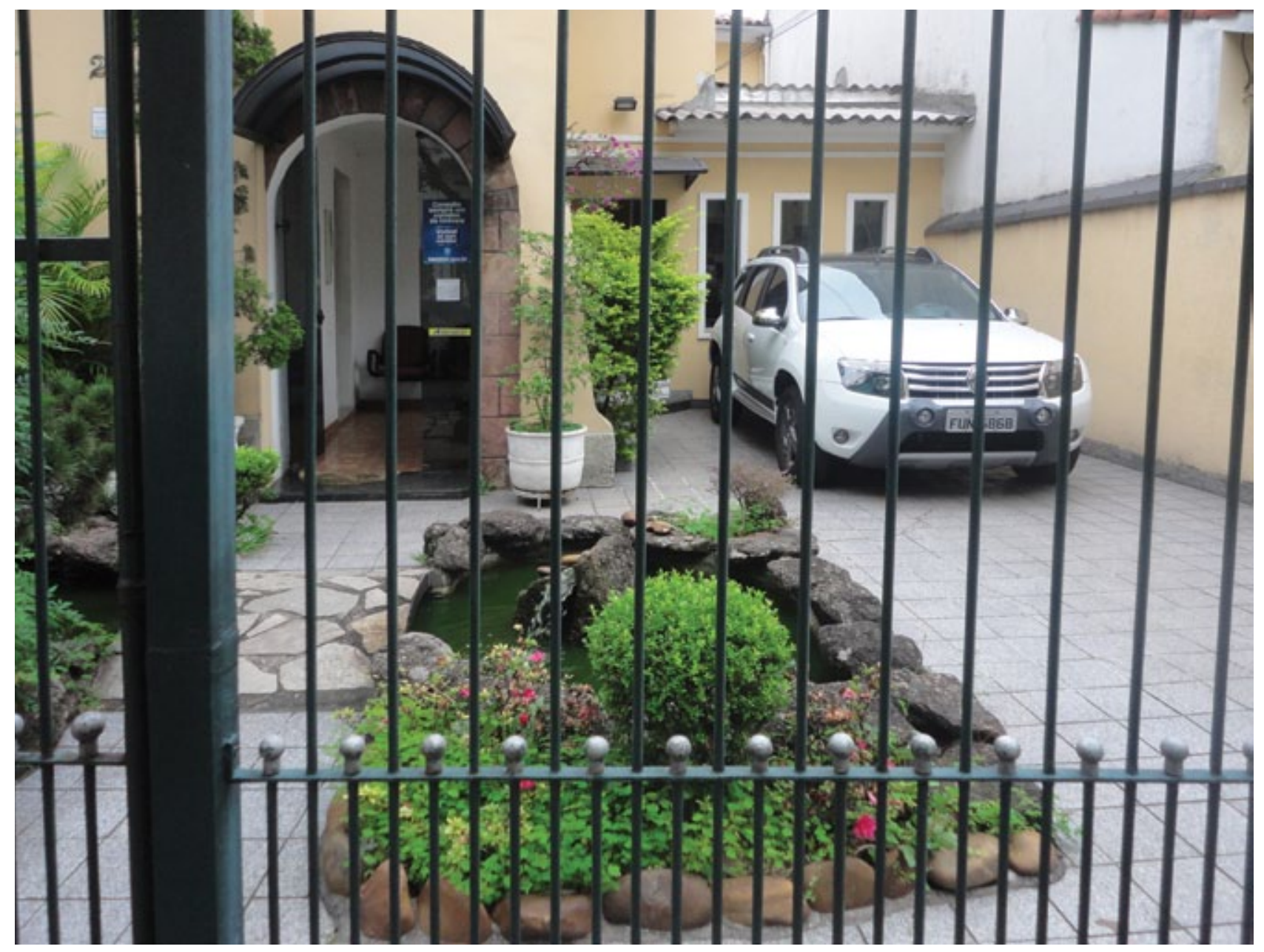




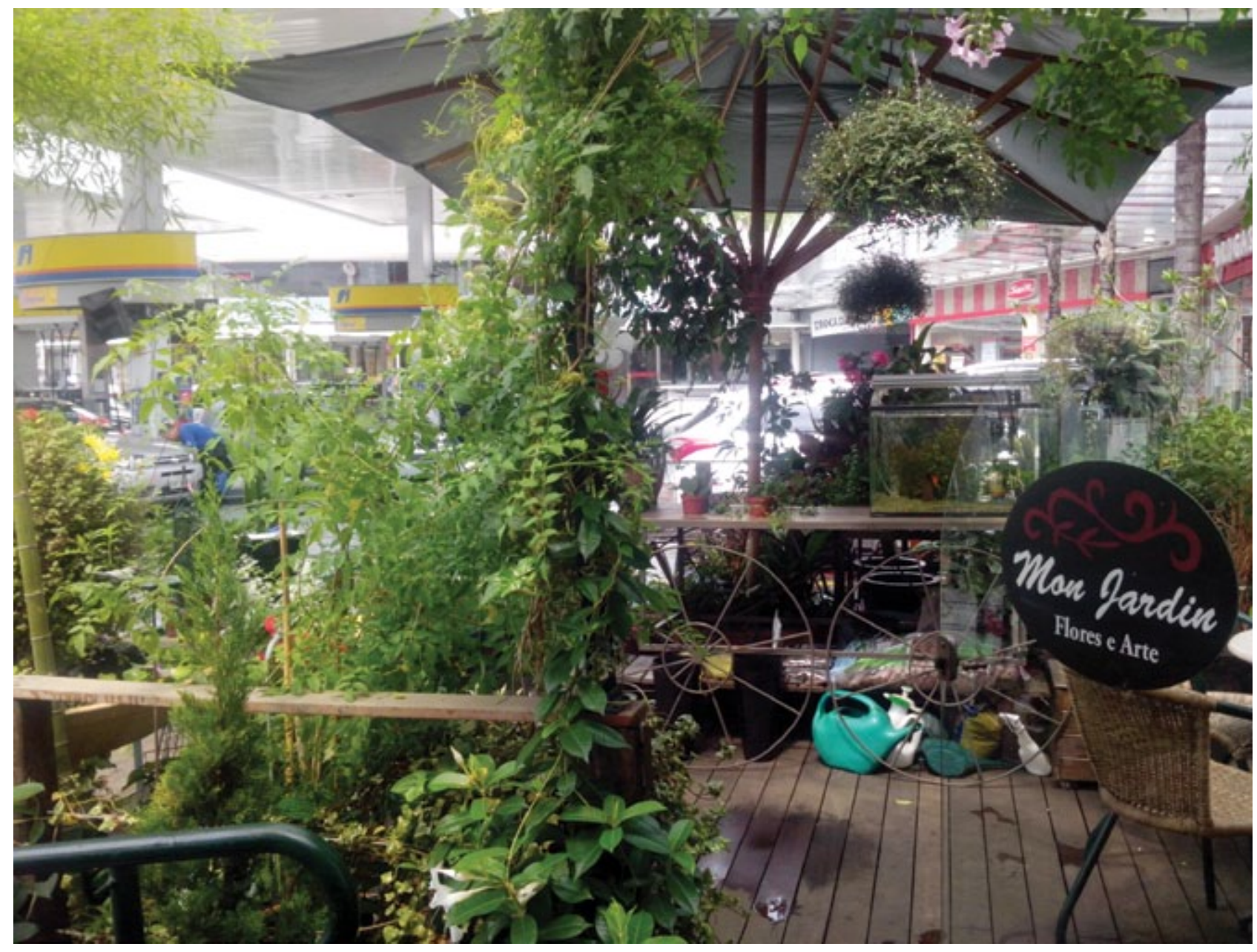




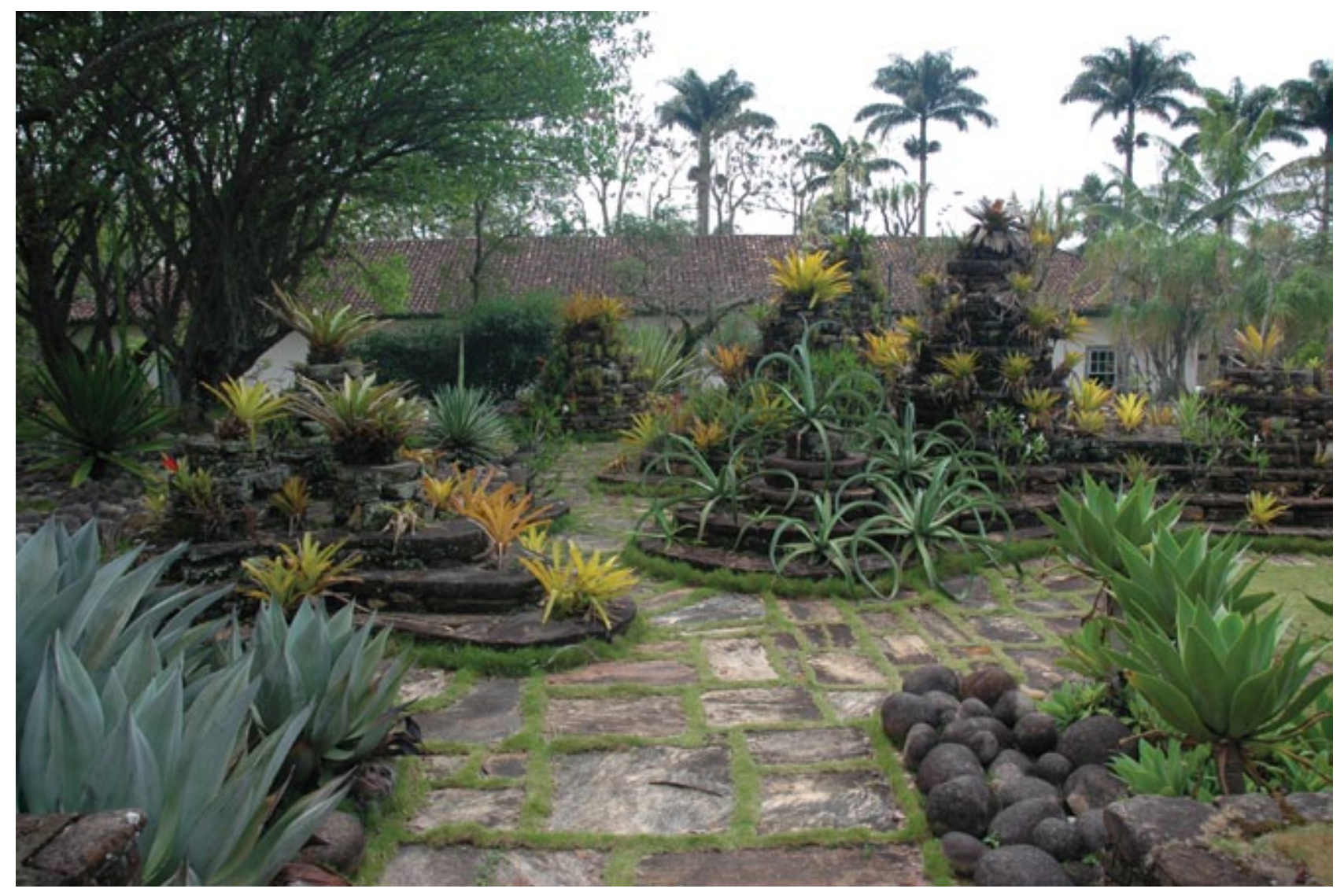




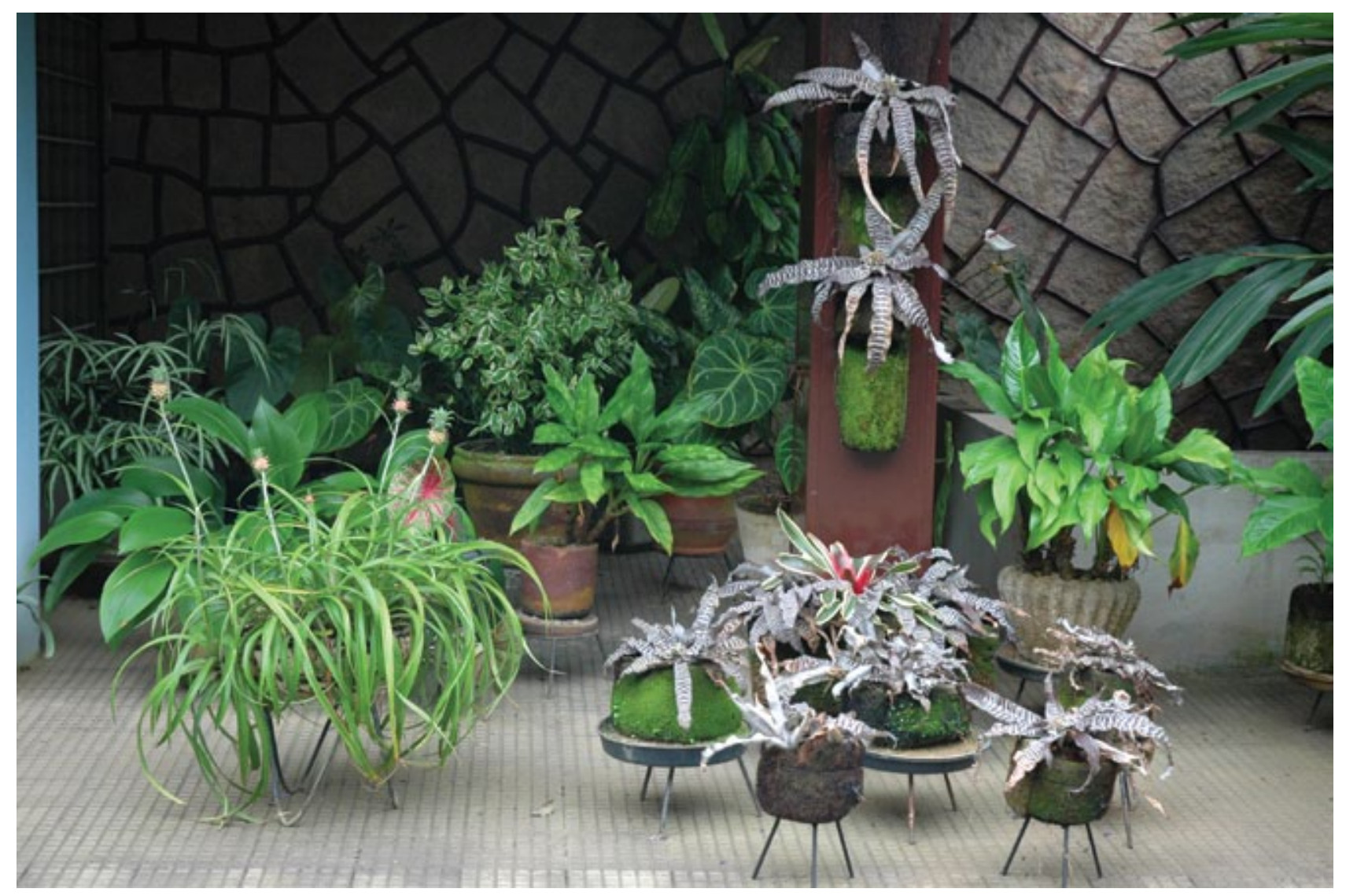





\section{verbetes}





\section{ventoux}

Hoje, movido unicamente pelo desejo de ver um lugar reputado por sua altura, escalei um monte, o mais alto da região, não sem razão denominado Ventoux.

Francesco Petrarca, Subida ao monte Ventoux, 26 de abril de 1336.

Os historiadores da paisagem há tempos atribuem à carta na qual Petrarca faz o relato de sua ascensão ao monte Ventoux um valor inaugural. Com efeito, Petrarca, decidindo escalar a montanha para simplesmente fruir da vista que pode ser desfrutada do seu cimo, teria sido o primeiro a encontrar a fórmula da experiência paisagística no sentido próprio do termo: a da contemplação desinteressada, do alto do mundo natural aberto ao olhar. Nisto residiria a "modernidade" do poeta e moralista italiano, do ponto de vista da história das concepções da natureza, bem como das relações práticas que o homem mantém com o mundo visível.

Jean-Marc Besse, Ver a Terra: Seis ensaios sobre a paisagem e a geografia.

Petrarca contempla livremente a totalidade da natureza, que, enquanto paisagem, é fruto e produto do espírito teórico, da unidade do cosmos. Não existem outras finalidades na experiência do poeta. A paisagem emana da theoria e é produzida no homem que sai para a natureza. O Homem entra na paisagem saindo de si mesmo. (...) A paisagem, do interior ao exterior, é sintomática de uma nova relação do homem com a natureza em sua totalidade. Seu "devir" torna implícita a abdicação do laço unitário por parte do homem; a paisagem é o resultado de um divórcio: o homem de um lado, a natureza de outro.

Massimo Venturi Ferriolo, Paisagem - Função estética na sociedade moderna.

\section{natureza}

A cesura na tradição se define com a cultura do Iluminismo. A natureza não é mais a ordem revelada e imutável da criação, mas o ambiente da existência humana; não é mais o modelo universal, mas um estímulo a que cada um reage de modo diferente; não é mais a fonte de todo o saber, mas o objeto da pesquisa cognitiva. É claro que o sujeito tende a modificar a realidade objetiva, seja nas coisas concretas (especialmente a arquitetura, a decoração etc.), seja no modo como passa a ter noção e consciência dela: o que era o valor a priori e absoluto da natureza, como criação ne varietur e modelo de toda invenção humana, é substituído pela ideologia como imagem formada pela mente, como ela gostaria que fosse tal realidade. $\mathrm{O}$ fato de o móvel ideológico, que tantas vezes se transforma em explicitamente político, ocupar o lugar do princípio metafísico da natureza-revelação, tanto na arte neoclássica como na romântica, mostra que ambas, apesar da aparente divergência, pertencem ao mesmo ciclo de pensamento. A diferença 
consiste sobretudo no tipo de postura (predominantemente racional ou passional) que o artista assume em relação à história e à realidade natural e social.

\section{(...)}

O pensamento do lluminismo não considera a natureza como uma forma ou figura criada de modo definitivo e sempre igual a si mesma, que se pode apenas representar ou imitar. A natureza que os homens percebem com os sentidos, apreendem com o intelecto, modificam com o agir (é do pensamento iluminista que nasce a tecnologia moderna, que não obedece a natureza, mas a transforma) é uma realidade interiorizada que tem na mente todos os seus possíveis desenvolvimentos, mesmo de ordem moral. Giulio Carlo Argan, Arte moderna.

\section{condições}

(...) podemos dizer que a invenção da paisagem ocidental supunha a reunião de duas condições. De início, a laicização dos elementos naturais, árvores, rochas, rios etc. Enquanto submissos à cena religiosa, eles não eram senão signos, distribuídos, ordenados em um espaço sagrado que, por si, Ihes oferecia qualquer interesse: ela poderia prejudicar a função edificante da obra. É preciso então que estes signos se destaquem da cena, recuem, se afastem; este será o papel, evidentemente decisivo, da perspectiva. Instituindo uma verdadeira profundidade, ela põe à distância estes elementos da futura paisagem e, ao mesmo tempo os laiciza. Eles não são mais satélites fixos, dispostos em torno de ícones centrais, eles formam o plano de fundo da cena (no lugar do fundo dourado da arte bizantina), e tudo fica diferente; é que lá eles se acham à parte e como que protegidos do sagrado. Mas ei-los condenados a forjar sua unidade. Esta é a segunda condição: é preciso daí em diante que os elementos naturais se organizem a si próprios em um grupo autônomo para não comprometer a homogeneidade do conjunto. Alain Roger, Nascimento da paisagem no Ocidente.

\section{promenade}

O homem coabita ainda em boa vizinhança com a terra que ele lavra;

Seus campos deitam sua paz sobre seu teto camponês;

(...)

Povo feliz dos campos, ainda não desperto para a liberdade,

Tu partilhas alegremente com teu campo a estreita lei da Natureza,

O ciclo sossegado das colheitas limita os desejos do teu coração;

Tua vida se desenrola com a mesma regularidade da tua lida cotidiana!

Mas o que me arrebata num golpe a visão encantadora?

Um espirito estranho recobre de repente todo o campo [ele mesmo tornado estranho] 
Tudo o que há pouco se fundia cordialmente se separa agora com secura Friedrich Schiller, A promenade.

(...) em Schiller, a liberdade implica, com a ciência e a indústria que são suas condições, um divórcio entre o homem e a natureza que originalmente o envolve. De natureza "sagrada", ela passa a natureza "perdida". A liberdade exige sua reificação em objeto. (...) A perda do ambiente natural é antes a condição de liberdade.

É então com a cidade, e com a ciência e o trabalho que caracterizam a sociedade moderna, que a liberdade como liberdade para o homem adquire uma existência; pois é na cidade que o homem se libera definitivamente da dominação da natureza para fazer dela um objeto de seu próprio poder e de suas próprias necessidades.

(...)

A fruição estética e o interesse estético pela natureza têm, então, por condições prévias, a liberdade e a dominação da sociedade sobre a natureza. (...) Viver livre é dominar uma natureza amansada.

Joachim Ritter, Paisagem - Função estética na sociedade moderna.

\section{recorte}

Pelo termo natureza, entendemos a cadeia sem fim das coisas, a criação e a aniquilação ininterruptas das formas, a unidade fluida do movimento de transformação, expressas pela continuidade da existência espacial e temporal. (...) Dizer "um pedaço de natureza" é, na verdade, uma contradição em si; a natureza não tem pedaços; ela é a unidade de um todo, e quando se lhe destaca um fragmento, este já não é mais inteiramente natureza.

(...)

Quanto à paisagem, é justamente sua delimitação, sua captura num raio visual efêmero ou duradouro que a definem essencialmente; sua base material ou pedaços isolados podem sempre passar por natureza - a paisagem reivindica um ser-por-si ótico, ou estético, ou atmosférico, em suma, uma singularidade, um caráter que a separa da unidade indivisível da natureza.

(...) o gosto pela paisagem, este produto tão especial, veio tardiamente, pois sua criação exigia a separação deste sentimento unitário da grande natureza. A individualização das formas de vida interiores e exteriores, a dissolução do vínculos e das relações originarias em prol de realidades autônomas e diferenciadas, esta fórmula maior do universo pós-medieval, permitiu também recortar a paisagem na natureza. Nada há de espantoso no fato da Antiguidade ou da Idade Média ignorarem o sentimento da paisagem; não se conhecia ainda esta determinação psíquica nem esta transformação autônoma, cujo ganho final foi confirmado com o 
nascimento da pintura de paisagem e, de certo modo, capitalizado por ela.

Aquilo que o artista faz - subtrair ao fluxo caótico e infinito do mundo, tal qual ele se dá de imediato, um pedaço delimitado, apreendê-lo e constituí-lo como uma unidade que, a partir de então, encontra em si o seu próprio sentido e corta os laços que a ligam ao universo para atá-los mais fortemente a si - isto então que o artista faz é precisamente o que nós também fazemos, mesmo nas menores circunstâncias, sem tantos princípios, e de um modo fragmentário pouco consciente de seus limites, no momento em que temos a visão de uma "paisagem", em vez da visão de uma pradaria, ou de uma casa, de um riacho, de um cortejo de nuvens.

Georg Simmel, Filosofia da paisagem.

\section{janela}

Mas o evento decisivo é certamente a aparição da janela, esta veduta interior ao quadro, mas que o abre para o exterior. Este achado flamengo é, simplesmente, a invenção da paisagem ocidental. A janela é, com efeito, a moldura que, ao isolá-lo, ao encaixá-lo no quadro, institui o país ${ }^{1}$ em paisagem. Tal subtração - extrair o mundo profano da cena sagrada - é, na realidade, uma adição: o agem se juntando ao país; e é

1 Pays, em francês, carrega não só a acepção de território de uma nação, ou de um Estado, mas também a de região, província, lugar. Ainda que menos vulgarizadas, as mesmas acepções estão presentes na palavra país, em português, o que justifica seu emprego nesta tradução (N.T.). verossímil que a primeira ocorrência ocidental da palavra "paisagem" - isto é, "landschap", em holandês, na segunda metade do século $X V$, literalmente "pedaço de país" - tenha designado esta porção do espaço delimitada pela janela pictórica. De todo modo, esta reúne as condições que acabo de colocar: laicização e unificação. Bastará ampliá-la às dimensões do quadro, onde ela ainda se insere, qual uma miniatura, para obter a paisagem ocidental.

Alain Roger, Nascimento da paisagem no Ocidente.

Sem dúvida, também a janela, dado que ela está ali, pronta para receber a imagem emoldurada de uma paisagem, é o instrumento paisagístico por excelência, o instrumento perfeito de sua própria possibilidade.

A janela, como tudo que se constrói, lembra o esforço de manter o selvagem à distância, o arco que emoldura, a coluna que designa e corta, uma simples extensão de um muro, que detém a invasão da floresta, a ruína que marca o tempo e é signo de que ele pode ser tomado por uma marca: todos esses aparatos são os mesmos que o temor estabeleceu para que a natureza-artifício triunfe, aquela que sabemos poder domar (olhar).

Anne Cauquelin, A invenção da paisagem.

LIX. A pintura de um quadro deve ser considerada como a vista de uma só janela. Em todo quadro sempre se deve considerar que se está olhando por uma janela, segundo o ponto de vista tomado. E pretendendo- 
se pintar uma bola circular em uma altura elevada, será necessário fazê-la ovalada, de maneira que com o escorço pareça redonda. Leonardo da Vinci, Tratado de pintura.

\section{trompe-I'oeil}

Através das portas da arte, abertas por Apolodoro, adentrou Zeuxis de Heracléia. (...) Seus contemporâneos e rivais foram Timantes, Androcides, Eupompo e Parrásio. O último, segundo se conta, travou uma disputa com Zeuxis. (...) Para a disputa, Zeuxis pintou um cacho de uvas. Quando mostrou o quadro, dois passarinhos imediatamente tentaram bicar as frutas. Zeuxis então pediu que Parrásio desembrulhasse seu quadro. Este então revelou que na verdade a pintura simulava a embalagem do quadro. Zeuxis imediatamente reconheceu a superioridade de Parrásio, pois se tinha logrado enganar os olhos dos passarinhos, este tinha enganado os olhos de um artista.

Plínio, o Velho, História natural. Livro XXXV.

Simulacros sem perspectivas, as figuras do trompe-l'oeil aparecem de repente, numa exatidão sideral, como desnudadas da aura do sentido e imersas num éter vazio. Aparências puras, possuem a ironia do excesso de realidade.

\section{(...)}

Se há portando um milagre no trompe-l'oeil, não é nunca na execução realista - as uvas de Zeuxis são tão verdadeiras que os pássaros vêm bicá-las. Absurdo. Nunca é de excesso de realidade que pode haver milagre, mas exatamente no contrário, no desfalecimento súbito da realidade e na vertigem de nela perder-se.

(...)

No trompe-l'oeil não é o caso de confundir-se com o real, é o caso de produzir um simulacro em plena consciência do jogo e do artifício imitando a terceira dimensão, lançar a dúvida sobre a realidade dessa terceira dimensão -, imitando e ultrapassando o efeito de real, de lançar uma dúvida radical sobre o princípio de realidade.

Jean Baudrillard, A arte da desaparição.

\section{conforto}

Durante muito tempo, a opinião comum esteve ligada - e ainda está - em pedir à arte uma reprodução fiel das coisas, que a conforte na sua percepção familiar do real; o que ela pede também à arte é ser confortada na ordem familiar de um mundo mantido pela ordem social ou pela ordem divina, ambas tranquilizadoras, como se recusasse perceber que a arte revela um mundo radicalmente outro.

Michel Ribon, A arte e a natureza.

Nos princípios do século XIX reconhecia-se que estava a mudar a situação da pintura de paisagem. Esta mudança deu-se rapidamente. (...) No decurso de um século, paisagens que pelo menos pretendiam ser boas imitações de natureza atingiram um lugar mais seguro no gosto popular do que qualquer outra 
forma de arte. Uma cena calma, com água em primeiro plano, refletindo o céu luminoso e enquadrada por árvores escuras, era algo que toda a gente estava de acordo em reconhecer como belo, exatamente como em épocas anteriores estavam de acordo acerca de um atleta nu ou uma santa com as mãos cruzadas sobre o peito. Quanto a um extenso panorama, grandes mudanças se deram desde a ascensão de Petrarca ao monte Ventoux, e com exceção do amor não há talvez mais nada que una pessoas diferentes como o prazer de um belo panorama.

Keneth Clark, Paisagem na arte.

\section{panorama}

Em 19 de junho de 1787, Robert Barker (17391806), um pintor anglo-irlandês, registrou um pedido de patente para o panorama: sua invenção, chamada de "A natureza a um golpe de vista", por representar objetos naturais ou imaginários, era concebida de modo a fazer com que os observadores se sentissem como se realmente estivessem no lugar representado.

(...)

O paradoxo de localidade produzido pelo panorama fez o espectador incapaz de racionalizar a relação entre o lugar que ele sabe em que está e o lugar em que agora se vê. (...) Cedo ou tarde, no entanto, dependendo da perspicácia do espectador, este estado de confusão dava lugar a uma percepção de que a perspectiva ilusória era uma pintura: as pinceladas, os limites do plano de perspectiva cilíndrica, a imobilidade do ponto de vista, todas essas limitações técnicas se tornam aparentes. Por fim, o espectador vê que, na verdade, ele não foi transportado por poderes sobrenaturais para outro lugar, mas foi apenas iludido por um pintor. Nesse sentido, o panorama não é efetivamente uma técnica para produzir a ilusão de imersão, mas, sim, uma demonstração de como funciona a ilusão e uma celebração do esclarecimento racional do espectador. O panorama era uma máquina para a desilusão, um espetáculo de ilusão esclarecida. Era o esplendor [o sublime], aberto todos os dias, exceto domingo, por apenas um xelim.

Markman Ellis, Spectacles within doors: panoramas of London in the 1790 s

Este era o grande fascínio das estampas de viagem encontradas no Kaiserpanorama: não importava onde iniciasse a ronda. Pois como a tela, com os assentos à frente, formava um círculo, cada uma passava por todas as posições, das quais se via, através de cada par de orifícios, a lonjura esmaecida do panorama. Lugar sempre se achava. E, sobretudo, já pelo fim de minha infância, quando a moda começou a se desinteressar dos panoramas imperiais, era comum circular naquele recinto semi-vazio. Música que, tempos mais tarde, tornou fastidiosas as viagens com o filme, pois com ela se dissolvia a imagem, da qual a fantasia era capaz de se nutrir - música não havia no Kaiserpanorama. Mas, para mim, um 
pequeno - e para ser franco - incômodo efeito parece superar toda aquela magia ilusória, que envolve oásis com pastorais ou muralhas em ruínas com marchas fúnebres. Era o toque da campainha que soava alguns segundos antes de a imagem se retirar aos solavancos para dar vez, primeiramente, a uma lacuna e, logo depois, à imagem seguinte. E toda vez que tocava a campainha, impregnavam-se profundamente com um toque melancólico de despedida as montanhas até o sopé, as cidades em todas as suas janelas reluzentes, os nativos distantes e pitorescos, as estações ferroviárias com sua fumaça amarela, os vinhedos nas colinas até as folhas mais diminutas.

(...)

As artes que aqui perduravam surgiram com o século XIX. (...) No ano de 1822, Daguerre inaugurara seu Diorama em Paris. Desde então essas caixas claras, cintilantes, aquários do distante e do passado, aclimataram-se em todas as avenidas e bulevares da moda.

Walter Benjamin, Infância em Berlim por volta de 1900.

O interesse pelos panoramas consiste em ver a verdadeira cidade - a cidade dentro da casa. Walter Benjamin, Passagens.

\section{domesticidade}

Verde Angra 611

Verde Versailles 645

Rosa Capri 164

Azul Arpoador 160

Azul Praia 153

Azul Piscina 154

Azul Profundo 156

Azul Mar 163

Azul Celeste 165

Oceano 170

Azul França 172

Oceanic 181

Marine 183

Azul Feriado 174

Seleção de cores do catálogo de tintas da Coral, 2014.

Não é a natureza "verdadeira" que transfigura a ambiência cotidiana, e sim as férias, esse simulacro natural, esse avesso da cotidianidade que vive, não de natureza, mas da Ideia de Natureza; são as férias que funcionam como modelo e delegam suas cores para o domínio do cotidiano primário. Jean Baudrillard, O sistema dos objetos.

\section{jardim}

Do francês jardin, que denota "terreno cercado em que se cultivam flores, ou árvores frutíferas ou legumes, hortaliças e vegetais comestíveis", tem origem no diminutivo do francês antigo jart (horto), que, por sua vez, deriva do frâncico gard, que significaria "cercado".

Dicionário etimológico Nova Fronteira 
A natureza parece querer esconder seus verdadeiros encantos dos olhos humanos que não são suficientemente sensíveis a eles, deturpando-os frequentemente. Ela evita lugares cheios de gente e é somente nos topos das montanhas, nas profundezas das florestas, ou em ilhas desertas, que ela revela seus arrebatadores encantos. Para os que a amam, mas não podem viajar tão longe para encontrá-la, nada resta a não ser cometer uma violência com a natureza e forçá-la a morar com eles; e isso não pode ser feito sem uma certa ilusão.

Jean Jaques Rousseau, La nouvelle Heloïse

Você já ouviu falar de paisagismo permanente? Esta é a mais nova alternativa do segmento de decoração.

As flores e plantas permanentes chegaram para ficar e encantar!

O paisagismo permanente requer poucos cuidados, e sua beleza e aparência não deixam nada a desejar ao paisagismo natural. Entenda nossos serviços:

Áreas de atuação: residencial e corporativo.

Realizamos todo tipo de serviço paisagístico, desde pequenos espaços a grandes áreas verdes com jardins personalizados, incluindo áreas externas.

Veja as fases que envolvem o processo:

- Identificação da necessidade do cliente;

- Criação de novo projeto ou repaginação de jardins já existentes com a substituição das plantas naturais por permanentes;

- Consultoria e desenvolvimento do projeto;

- Apresentação e aprovação do cliente;
- Implantação com equipe especializada e treinada.

Benefícios dos nossos produtos:

- Resistência: resistem às mudanças de temperatura. Se adequam tanto à temperatura ambiente quanto a locais climatizados.

- Saúde: não atraem insetos e colaboram com o combate à dengue.

- Sustentabilidade: não precisam de água, preservando o meio ambiente.

- Durabilidade: as flores e plantas permanecem sempre bonitas, pois não deterioram com o tempo.

- Economia: eliminam despesas de manutenção mensal com cuidados e/ou reposição de flores e plantas.

- Praticidade: não demandam tempo para cuidados.

- Antialérgico: indicados para pessoas alérgicas ao pólen.

Site da empresa especializada em paisagismo

permanente Rivivere.

Foi o movimento pitoresco de meados do século 18 que inventou nossa ideia de como uma paisagem inglesa deveria parecer - e foram as pinturas de Claude Lorrain que ajudaram a inspirar o movimento. Cinquenta anos depois que morreu, em 1682, suas obras foram avidamente procuradas nas casas de leilão de Londres e por fãs aristocratas como Frederick, o príncipe de Gales. A visão arcadiana do pintor foi recriada por toda a Inglaterra nos parques e jardins das casas de campo, de Blenheim a Stowe.

Harry Mount, Como um francês inventou o jardim Inglês 


\section{pitoresco}

O "pitoresco" é uma qualidade que repercute na natureza pelo "gosto" dos pintores, e especialmente dos pintores do período barroco. Foi um pintor e tratadista, Alexander Cozens (c.1717-86), que o teorizou, preocupado em dar à pintura inglesa do século XVIII, predominantemente retratista, uma escola de paisagistas. (...) A poética do "pitoresco" medeia a passagem da sensação ao sentimento: é exatamente nesse processo do físico ao moral que o artista-educador é guia dos contemporâneos (...) tanto quanto na pintura, expressava-se na jardinagem, que era essencialmente um educar a natureza sem destruir a espontaneidade. (...) O repertório era o mais variado possível: árvores, troncos caídos, animais no pasto, pequenas figuras. A execução é rápida, como se não fosse preciso dar muita atenção às coisas. Sempre exata a referência ao lugar, quase seguindo o gosto pelo "turismo" que vinha se difundindo.

Guilio Carlo Argan, Arte moderna.

\section{nostalgia}

Aquilo que nós (...) chamávamos natureza (...) estava recoberto por uma imagem bem precisa, ou, sobretudo, só aparecia por meio dessa imagem.

A chamada natureza se compunha diante de nós por uma série de quadros, imagens artificiais, posta diante da confusão das coisas; ela organizava a matéria diversa e cambiante segundo uma lei implícita, e, quando pensávamos nos banhar na verdade do mundo tal qual ele se nos apresentava, não fazíamos nada além de reproduzir esquemas mentais, plenos de uma evidência longínqua, e milhares de projeções anteriores. Essa constante redução aos limites de uma moldura, ali montada por gerações de olhares, pesava sobre nossos pensamentos, por ela impiedosamente orientados.

(...)

Desse modo, aquilo que olhávamos apaixonadamente como a manifestação absoluta da presença do mundo em torno de nós, a natureza, para qual lançávamos olhares admirativos e quase religiosos, era em suma apenas a convergência em um único ponto de projetos que tinham atravessado a história, obras que se apoiavam umas às outras até formar esse conjunto coerente na diversidade e que conferiam ao espetáculo a evidência de uma natureza. Inocentemente presos à armadilha, contemplávamos não uma exterioridade, como acreditávamos, mas nossas próprias construções intelectuais. Acreditando sair de nós mesmos mediante um êxtase providencial, estávamos simplesmente admirados com nossos próprios modos de ver.

Anne Cauquelin, A invenção paisagem.

Dois poetas da antiguidade, Ovídio e Virgílio inspiraram as imaginações dos artistas da Renascença. O primeiro destes, com as suas claras e pormenorizadas descrições do fabuloso, era o favorito dos pintores de figura, mas Virgílio foi o inspirador dos paisagistas. A razão reside não só 
nas delicadas sugestões paisagísticas que ocorrem na Eneida, mas também o mito da rusticidade ideal em que era mestre. As suas obras demonstram um conhecimento em primeira mão do campo, e muitos dos melhores humanistas, de Petrarca em diante, administraram as suas propriedades segundo os conselhos das Geórgicas. Mas este elemento de realismo combina-se com o sonho mais encantador que desde sempre consolou a espécie humana, o mito da Idade do Ouro, na qual o homem vivia com os frutos da terra, pacificamente, religiosamente, e com uma simplicidade primitiva.

Keneth Clark, Paisagem na arte.

\section{paraíso}

Remonta ao latim paradisus, que significa "jardim próximo à casa". Seguindo sua longa trilha que, do latim, remonta ao grego parádeisos, passando pelo hebraico pardês e chega finalmente ao termo avéstico pairidaeza, composto por pairi- (ao redor) e -diz (criar, fazer); temos que paraíso, por fim, designa "uma área, um jardim murado."

Dicionário etimológico Nova Fronteira

Os interiores com luz artificial e ar condicionado complementam a luz ofuscante e o calor do deserto agorafóbico, na escala do automóvel. Mas o pátio interno do motel atrás do cassino é literalmente um oásis em um ambiente hostil. Seja moderno orgânico ou neoclássico barroco, ele contém os elementos fundamentais do oásis clássico: jardins, água, folhagens, escala íntima e espaço fechado. Ali estão a piscina, as palmeiras, a grama e outras importações horticulturais, plantadas num pátio calçado, cercado por suítes de hotel com sacadas ou terraços voltados para este pátio, de modo a garantir privacidade. O que dá emoção aos guarda-sóis e espreguiçadeiras é a lembrança recente e vívida dos carros hostis no deserto de asfalto lá fora. O oásis do pedestre no deserto de Las Vegas é o recinto principesco de Alhambra e a apoteose de todos os pátios internos de motel com piscinas mais simbólicas do que úteis, dos restaurantes baixos e planos com interiores exóticos e das bonitas galerias comerciais da strip americana.

Robert Venturi e Denise Scott Brown, Aprendendo com Las Vegas.

Paradise é uma região censo-designada localizada no estado americano de Nevada, no Condado de Clark. Trata-se de um subúrbio não incorporado de Las Vegas. No censo de 2000, Paradise tinha uma população de 186.070 habitantes e, em 2005, a população estimava-se em 211.509 pessoas.

(...)

Em Paradise fica o Aeroporto Internacional de Las Vegas e a maior parte do Las Vegas Strip, incluindo os famosos hotéis e cassinos, como o Caesars Palace e o MGM Grand. Muitas pessoas julgam que Paradise faz parte da cidade de Las Vegas, mas a maioria 
dos turistas que visita Las Vegas passa mais tempo em Paradise do que na própria cidade de Las Vegas.

Verbete Paradise (Nevada), Wikipedia.

Oasis Cancun Hotel: Uma das melhores relações custo-benefício na região, é all inclusive e fica em uma posição excelente da zona hoteleira, além de ter um grande complexo gastronômico composto por 10 restaurantes e 11 bares. Uma enorme piscina atravessa a propriedade como se fosse um rio, com várias áreas espaçadas para tomar sol ou beber um drinque refrescante. As noites são animadas por shows variados, que vão de apresentações musicais a performances acrobáticas.

Menu viajante, TAM viagens.

Americano

Aviation

Casino

Daiquiri

Dry martini

Old fashioned

Paradise

Porto flip

Screwdriver

Tuxedo

Champagne cocktail

Cosmopolitan

Cuba libre

Golden dream

Long island iced tea
Sea breeze

Sex on the beach

Tequila sunrise

Seleção de cocktails realizada com base na lista oficial da International Bartender Association.

\section{vacance}

O importante é dar a impressão de um ambiente de férias, isto é, de um antípoda do cotidianoque reflita, de umlado, descontração, bem-estar, alegria, liberdade, prazer e, de outro, repouso, espaço. Dar a impressão de imobilidade do tempo, relaxamento, assim como um certo romantismo, uma experiência especial e fora do comum. Trata-se de apresentar algo de belo, que corresponda à ideia de férias e fuja do comum. Algo que não se pode ter na vida todos os dias (por exemplo, a piscina municipal) e que a região de veraneio não lembre a vida cotidiana (por exemplo, a aparência normal dos autóctones). É necessário prudência quando se deseja mostrar pessoas que não pertençam ao meio cultural normal. Elas não devem parecer muito estranhas e não podem se afastar do nosso padrão de beleza para evitar o preconceito e até despertar temores profundos.

Por outro lado, seria vantajosa a utilização de um símbolo típico das férias, como o Sol, o guarda-sol, a cadeira de praia etc. Nesta área, cabe a cada operador de viagens descobrir o que melhor lhe convém.

K.D Hartmann, Zur Gestaltung von Titelseitein auf urlaubskatalogen (Para a concepção de primeira página de catálogos de férias) 
A partir de um conceito arquitetônico alpino, o Vacance Hotel possui 208 suítes, sendo 39 Suítes com 02 ambientes e 02 banheiros. Todas possuem piso hipoalergênico (piso laminado em madeira), camas tipo box, vista panorâmica e são equipadas com TV, som ambiente, ar-condicionado, frigobar, telefone com discagem direta e acesso a internet, oferecendo 05 tipos de acomodações. O Vacance Hotel se diferencia também pela infraestrutura de serviços, contando com mini-shopping, amplo restaurante, 02 bares, copa de apoio para alimentação infantil, além de room service.

Nossa área de lazer inclui $200.000 \mathrm{~m}^{2}$ de área verde exclusiva, com bosques, lago, mini-golf, peteca mineira, quadras de vôlei de areia, quadra de basquete, campo de futebol oficial, salão de jogos, fitness center e terraços panorâmicos para leitura. O Vacance Hotel possui duas opções para quem gosta de água: as piscinas frias Piazza Dell'Acqua e as piscinas aquecidas a $32^{\circ} \mathrm{com}$ água mineral L'Acqua Ventura.

Site do Vacance Hotel, em Águas de Lindóia (SP).

A Vacances Agência de Viagens e Turismo é uma agência que trabalha com uma proposta diferenciada no mercado: atendimento personalizado ao cliente.

Ao entrar em contato conosco você será atendido por pessoas que realmente conhecem o assunto, sendo informado sobre os melhores destinos, os melhores hotéis e os preços mais baixos, além de locais para diversão e entretenimento. Tudo de acordo com o seu gosto e o seu bolso.

Nossa equipe é composta de profissionais competentes e totalmente qualificados na área, além de uma estrutura organizada e preparada para receber bem e satisfazer suas necessidades. Nossa missão é trabalhar para que o cliente desfrute da satisfação de viajar em sua plenitude.

Site da agência de viagens Vacances, de Santo André (SP).

Refúgio paradisíaco: Para escapar um pouco do agito, o hotel Dom Pedro Laguna é um oásis na capital cearense. De frente para o mar e integrado a uma enorme lagoa, o resort tem vilas construídas sobre a água, é vizinho a um enorme campo de golfe e oferece opções de lazer para todos. Um pequeno paraíso privativo.

Menu viajante, TAM viagens.

\section{Souvenir}

Um modo de atestar a experiência, tirar fotos é também uma forma de recusá-la - ao limitar a experiência a uma busca do fotogênico, ao converter a experiência em uma imagem, um souvenir. Viajar se torna uma estratégia de acumular fotos. A própria atividade de tirar fotos é tranquilizante e mitiga sentimentos gerais de desorientação que podem ser exacerbados pela viagem. Os turistas, em sua maioria, sentem-se compelidos a pôr a câmera entre si mesmos e tudo de notável que encontram. Inseguros sobre suas reações, 
tiram uma foto. Isso dá forma à experiência: pare, tire uma foto e vá em frente.

Susan Sontag, Sobre fotografia.

Nossa relação com a imagem e com o espaço se apresenta sob um duplo aspecto: recebemos imagens (fixas ou móveis) e também as produzimos. Fabricar imagens (fotografar, filmar) é, ao mesmo tempo, se apropriar do espaço, transformá-lo e, de certa maneira, consumi-lo.

Marc Augé, L'impossible voyage, le tourisme et ses images.

\section{miragem}

Sf. 1. efeito óptico que ocorre nas horas mais quentes, esp. nos desertos, produzido pela reflexão da luz solar, que cria uma imagem semelhante a um lago azul, onde por vezes se refletem imagens de vegetação ou cidades distantes, e que desaparece à medida que nos aproximamos. 2. p.metf. aquilo que se apresenta como algo muito bom, mas que não é verdadeiro; falsa realidade, ilusão, quimera, sonho.

Etimologia. fr. mirage (1753) 'fenômeno óptico, ilusão', der. do fr. mirer 'olhar atentamente', do lat. mirare 'admirar-se, ver, olhar'; ver mir-; Grande dicionário Houaiss da língua portuguesa.

\section{cidade-ficção}

Houve um tempo em que o real distinguiase nitidamente da ficção, quando íamos a lugares claramente delimitados (ginásios esportivos, quermesses, cinemas, parques de diversões), nos quais a ficção copiava o real. Em nossos dias, imperceptivelmente é o real que copia a ficção. Qualquer monumento de aldeola ganha uma iluminação de cenário. E quando não se tem tempo de ir ver o cenário, ele é reproduzido (imagens de imagens) em outdoors na beira da estrada.

Marc Augé, L'impossible voyage, le tourisme et ses images.

\section{geografia}

O Norte não é somente uma direção como qualquer outra, é uma região de nossa imaginação ou de nossa recordação, é o vento, o frio, o gelo, os mares hostis, os solos pobres. O Sul quer dizer sol, céu ardente, capoeiras pedregosas ou huertas fecundas pela água. Colorações afetivas tingem palavras que deveriam se registrar sem mais, como Champanhe, Bocage, Java, Suisse, Riviera.

Eric Dardel, O homem e a Terra: natureza da realidade geográfica.

\section{nome fantasia}

Escolher o "Nome Fantasia" para sua empresa não precisa ser um processo apressado nem cansativo. Afinal, o nome comercial vai ser o primeiro chamariz do serviço oferecido pelo seu negócio. Um bom nome pode tanto atrair mais 
clientes como reduzir custos com publicidade. É por isso que o empresário deve estar pronto para pesquisar quais os termos mais adequados para representar a sua empresa.

Então, antes de pensar em como vai se chamar a sua empresa é preciso que o empresário considere diversos fatores na hora da escolha do nome, e, se possível, que ele se faça as seguintes perguntas:

1 - Que palavras chamam a atenção do meu público-alvo?

2 - Qual o melhor termo para descrever o serviço que ofereço?

3 - Que símbolos melhor representam os trabalhos que minha empresa faz?

4 - Quais os nomes dos concorrentes? Há algum padrão no mercado usado por empresas do mesmo ramo?

Essas perguntas ajudam o empresário a garantir uma lista de "Nomes Fantasia" enquadrados com a proposta de trabalho oferecido pela empresa a ser criada. Isso facilita futuras campanhas de marketing, além de ser um bom chamariz para futuros clientes interessados.

Blog Nuven Digital, Criando um "nome fantasia" para sua empresa.

A primeira função da marca é particularizar, a segunda é mobilizar conotações afetivas. Numa economia de concorrência, poucos produtos conservam uma superioridade técnica. Para que venda bem e desperte ligações afetivas suficientes para garantir fidelidade à marca, é preciso individualizar o produto, dotando-o de associações e imagens, atribuindo-Ihes significações em diversos níveis.

Nelly Carvalho, Publicidade: a linguagem da sedução.

\section{reificação}

Substantivo feminino. 1. ato ou efeito de reificar. 2. operação mediante a qual uma abstração se converte em objeto concreto, em coisa. 3. fil processo em que uma realidade social ou subjetiva de natureza dinâmica e criativa passa a apresentar determinadas características - fixidez, automatismo, passividade - de um objeto inorgânico, perdendo sua autonomia e autoconsciência. 4. fil segundo Georg Lukács (1885-1971), baseado em um conceito de Karl Marx (1818-1883), processo histórico inerente às sociedades capitalistas, caracterizado por uma transformação da atividade produtiva, das relações sociais e da própria subjetividade humana, que se conformariam progressivamente com o caráter inanimado, quantitativo e automático dos objetos ou mercadorias circulantes no mercado cf. alienação (fil pol) Etimologia. reificar + -ção; rad. do lat. res,rei 'coisa, matéria' + - i- + -ficar Sinônímia e Variantes. Coisificação. Grande dicionário Houaiss da língua portuguesa. 


\section{fantasmagoria}

A produção de imagens, essa atividade intensa de ficção que nos habita e cuja extensão e importância desconhecemos, deriva bastante da magia: a realidade do mundo na qual cremos tanto só nos é perceptível por meio de um véu de imagens, a ponto de - querendo rasgar esse véu - nós nos encontrarmos muitas vezes confrontados com o vazio. Artifício da imagem necessária para que se assegure a perenidade, para que dure o prazer, a tensão da vida. Necessária transformação da realidade em imagem e, outra vez, da imagem em realidade: nesse duplo movimento, algo, um sopro é transmitido: a retórica pôs sua pitada de sal. Pois, revirada, a realidade não é mais exatamente a mesma: ela é duplicada, reforçada pela ficção.

(...)

Interpenetram-se no mesmo movimento realidade suposta e ficção presente, até que sua diferença se esvaeça em uma passagem quase-invisível. (...) Essa passagem é exatamente o lugar do discurso retórico, que permite, por suas figuras, a transformação do nome em coisa e do real em simulação.

(...)

De fato, estamos na raiz das condições de possibilidade para que uma imagem assuma o lugar de natureza.

Anne Cauquelin, A invenção da paisagem.

Nós somos os criadores desenfreados de imagens, mas secretamente somos iconoclastas. Não daqueles que destroem as imagens, mas destes que fabricam uma profusão de imagens em que não há nada para ver. A maior parte das imagens contemporâneas, vídeo, pintura, artes plásticas, audiovisual, imagens de síntese, são literalmente imagens em que não há nada para ver, imagens sem rastros, sem sombra, sem consequências. Tudo o que se pressente é que por trás de cada uma delas alguma coisa desapareceu. E elas são apenas isto: o rastro de algo que desapareceu.

Jean Baudrillard, A arte da desaparição.

O corpo e o meio estão igualmente envolvidos no sentido das imagens em funerais, à medida que é no lugar do corpo ausente do morto que são instaladas as imagens. Mas essas imagens, por sua vez, permaneciam na carência de um corpo artificial, para ocupar o lugar vago do falecido. Aquele corpo artificial pode ser chamado de meio (não só material), no sentido em que as imagens necessitavam de corporificação para adquirir qualquer forma de visibilidade. Nesse sentido, o corpo perdido é trocado pelo corpo virtual da imagem. É nesse ponto que alcançamos a origem da exata contradição que para sempre caracterizará a imagem: imagens, como todos concordamos, fazem uma ausência visível ao transformá-la em uma nova forma de presença.

Hans Belting, Por uma antropologia da imagem.

- Considera então o seguinte. Que objetivo propõe-se a pintura com relação a cada 
objeto? O de representar o que é tal como é ou o que parece tal como parece; a imitação da aparência ou da realidade?

- Da aparência, diz ele.

- A arte de imitar está, então, bem distante da verdade, e se pode tudo executar, ao que parece, é porque atinge apenas uma pequena parte de cada coisa, e essa parte não é mais que um fantasma.

Platão, A República.

Ver na ausência da coisa vista: Quando uma pessoa lembra algo que viu alguma vez ou se entrega a fantasias, ou sonhos, certamente não está sob controle de um estímulo presente. Não estará então vendo uma cópia? Ver na ausência da coisa vista é experiência familiar a quase toda a gente, mas a formulação tradicional é uma metáfora. Tendemos a agir no sentido de produzir estímulos que são reforçadores quando vistos. Se achamos reforçadora a cidade de Veneza (aludimos a um efeito reforçador quando dizemos que ela é bela), podemos ir a Veneza para sermos reforçados. Se não pudermos ir, poderemos comprar quadros de Veneza - quadros que retratam colorida e realisticamente seus mais belos aspectos, embora um desenho em preto e branco possa ser suficiente. (...) Tendemos a adotar esse comportamento - isto é, o comportamento de ver Veneza - mesmo quando haja muito pouco no ambiente que nos cerca que tenha alguma semelhança com a cidade. De acordo com um dicionário, a fantasia é definida como "o ato ou função de formar imagens ou representações por percepção direta ou pela memória"; poderíamos igualmente dizer, porém, que é o ato ou função de ver por percepção direta ou pela memória.

B.F Skinner, Sobre o behaviorismo.

\section{clichê}

substantivo masculino. 1. gráf placa de metal, ger. zinco, gravada fotomecanicamente em relevo, obtida por meio de estereotipia, galvanotipia ou fotogravura, destinada à impressão de imagens e textos em prensa tipográfica; fotótipo. 2. p.ext. gráf o texto ou a imagem impressos por esse processo. 3. estl frase freq. rebuscada que se banaliza por ser muito repetida, transformando-se em unidade linguística estereotipada, de fácil emprego pelo emissor e fácil compreensão pelo receptor; lugar-comum, chavão. 4. fot imagem fotográfica negativa. 5. jor cada uma das tiragens sucessivamente atualizadas de uma edição de jornal. < a notícia da demissão do ministro saiu no segundo c. >

Gramática. voc. consid. gal. pelos puristas, que sugeriram em seu lugar: chapa, molde, matriz, chavão, lugar-comum.

Etimologia. fr. cliché (1809) 'chapa obtida pelo processo de estereotipia', part.pas. substv. de clicher 'estereotipar', talvez de orig. onom. a partir do ruído da matriz abatendo-se sobre o metal em fusão; f.hist. 1872 cliché;

Sinônímia e Variantes. ver lugar-comum.

Grande dicionário Houaiss da língua portuguesa. 
Em suma, o que é a aura? É uma figura singular, composta de elementos espaciais e temporais: a aparição única de uma coisa distante por mais perto que ela esteja. Observar, em repouso, numa tarde de verão, uma cadeia de montanhas no horizonte, ou um galho, que projeta sua sombra sobre nós, significa respirar a aura dessas montanhas, desse galho. Graças a essa definição, é fácil identificar os fatores sociais específicos que condicionam o declínio atual da aura. Ela deriva de duas circunstâncias, estreitamente ligadas à crescente difusão e intensidade dos movimentos de massas. Fazer as coisas "ficarem mais próximas" é uma preocupação tão apaixonada das massas modernas como sua tendência a superar o caráter único de todos os fatos através da sua reprodutibilidade. Cada dia fica mais irresistível a necessidade de possuir o objeto, de tão perto quanto possível, na imagem, ou antes, na sua cópia, na sua reprodução. Cada dia fica mais nítido a diferença entre a reprodução, como ela nos é oferecida pelas revistas ilustradas e pelas atualidades cinematográficas, e a imagem. Nesta, a unidade e a durabilidade se associam tão intimamente como, na reprodução, a transitoriedade e a repetibilidade. Retirar o objeto do seu invólucro, destruir sua aura, é a característica de uma forma de percepção cuja capacidade de captar "o semelhante no mundo" é tão aguda, que graças à reprodução ela consegue captá-lo até no fenômeno único. Assim se manifesta na esfera sensorial a tendência que na esfera teórica explica a importância crescente da estatística. Orientar a realidade em função das massas e as massas em função da realidade é um processo de imenso alcance, tanto para o pensamento como para a intuição.

Walter Benjamin, A obra de arte na era de sua reprodutibilidade técnica.

\section{eco}

sm (gr ekhó) (...) 2 Fís Repetição, mais ou menos clara, de um som refletido por um corpo. 3 Som repetido. 4 Repetição. 5 Pessoa que repete. (...)7 Recordação, memória, vestígio. 8 Fama. (...) 11 Reprodução de som ou notícia semelhante à causa que os produziu; correspondência. (...)

Dicionário Michaelis da língua portuguesa.

\section{gasto}

adj (part irreg de gastar) 1 Cansado, exausto, fraco, lasso. 2 Avelhantado. 3 Cotiado, deteriorado pelo uso. 4 Que se gastou. 5 Consumido, despendido.sm 1 Ação ou efeito de gastar. 2 Consumo. 3 Despesa, gastamento. Dispêndio. 5 Quebra ou detrimentodas coisas pelo uso ou ação do tempo. 6 Aquilo que se gastou.

Dicionário Michaelis da língua portuguesa. 


\section{happy painting}

Bill Alexander nasceu na Prússia em 1915. Ele iniciou sua carreira pintando murais e decorando carruagens para a aristocracia alemã. Exceto por algumas aulas formais tomadas em uma escola de arte no Canadá, Bill é um artista autodidata. Aos 50 anos, seu amor pela pintura o fez cair na estrada. Ele e sua esposa Margarete cruzaram os Estados Unidos ensinando e pintando. Foi durante este período que Bill simplificou o método tradicional de pintura a óleo, desenvolvendo suas próprias tintas, que permitiam que se aplicasse camadas umas sobre as outras sem a necessidade de esperar que secassem. Isto, junto com sua maneira original de preparar a tela, o "branco mágico", e suas ferramentas especialmente desenhadas, o habilitou a criar um método de pintura em uma sessão [in one sitting] - dando origem ao que denominou Alexander Wet-on-Wet Technique .

É reconhecido como o The Happy Painter, [O Pintor Feliz] por causa de seus programas The Magic of Oil Painting e The Art of Bill Alexander, na emissora pública de TV norteamericana PBS. Hoje, Bill vive com sua esposa no Canadá, em meio às montanhas e árvores que pinta tão bem².

W. Alexander, Secrets to the magic of oil painting.

2 A edição do livro Secrets to the Magic of Oil Painting, na qual consta a biografia de Bill Alexander, é anterior ao falecimento do pintor, em 1997.
Sim, você já o viu antes. Ele é aquele cara de fala mansa que pinta nuvens felizes, montanhas e árvores na televisão em cerca de vinte e seis minutos. Empunhando um grande pincel daqueles utilizados em pintura de paredes, ele diz calmamente à audiência: "Você consegue fazer isso". Seu programa, Joy of painting, é o mais reconhecido e mais assistido programa de arte na TV em toda a história.

Nativo de Orlando, Flórida, Bob Ross começou a pintar aos 18 anos, quando se juntou às forças aéreas norte-americanas e ficou lotado no Alaska. Ele frequentou muitos cursos de arte em universidades e escolas e, depois de ver Bill Alexander na televisão, desenvolveu sua própria técnica de pintura rápida: $B o b$ Ross Wet-on-Wet Technique ${ }^{\circledR}$.

Em 1981, enquanto Bob excursionava pelos EUA para ensinar seu estilo de pintura, uma de suas alunas ficou profundamente impressionada com seu carisma na sala de aula. "Eu vi e senti a magia acontecendo", relatou Annette Kowalski, "e perguntei a mim mesma: havia uma maneira de compartilhar esta alegria com todos?". A parceria de negócios foi formada - Bob Ross Company! O primeiro Joy of painting foi ao ar em 1982 com produção modesta, sem edição nem tampouco ensaios. Vinte e cinco anos e 403 episódios depois, é o programa de arte mais assistido, senão a atração do tipo "how to" [como fazer] mais popular da televisão.

Mas há algo interessante por trás da enorme popularidade alcançada pelo programa. Muitos dos espectadores mais fiéis de Bob não são pintores. Eles apenas gostam de relaxar e descontrair ouvindo sua fala suave e suas palavras encorajadoras.

Site da Bob Ross Company. 


\section{sujeito indeterminado}

É chamado sujeito indeterminado aquele que, apesar de existir, não pode ser determinado pelo contexto ou pela terminação do verbo. Ele tem como função expressar: situação na qual é desconhecido o sujeito; situação na qual não interessa a identificação do sujeito; situação na qual a identificação do sujeito é irrelevante; situação onde o sujeito não é identificado e não pode ser o ouvinte ou estar relacionado a ele; situação onde o sujeito não é identificado, mas que denota envolvimento, nosso ou o do ouvinte, com ele.

O sujeito indeterminado pode ser identificado a partir da terceira pessoa do plural dos verbos, pela terceira pessoa do singular dos verbos seguida do pronome ou índice de indeterminação do sujeito "se", ou, ainda, pela terceira pessoa do singular sozinha.

Sujeito indeterminado com verbo na terceira pessoa do plural: além de estar na terceira pessoa do plural, o verbo não se refere a qualquer termo identificado anteriormente.

Afrânio Garcia, Tipos de sujeito indeterminado.

\section{standard}

sm (ingl) Tipo ou modelo uniforme de produção; padrão, paradigma.

Dicionário Michaelis da língua portuguesa.

O "Do it yourself", um tipo de comportamento recomendado atualmente para o tempo livre, inscreve-se, não obstante, em um contexto mais amplo. Eu já o designei, há mais de trinta anos, como pseudoatividade. Desde então, a pseudo-atividade ampliou-se assustadoramente, também e precisamente entre aqueles que se sentem como questionadores da sociedade. De uma forma geral, pode-se presumir, na pseudoatividade, uma necessidade represada de mudanças nas relações fossilizadas. Pseudoatividade é espontaneidade mal orientada. Mal orientada, mas não por acaso, e sim porque as pessoas pressentem surdamente quão difícil seria para elas mudar o que pesa sobre seus ombros. Preferem deixarse desviar para atividades aparentes, ilusórias, para satisfações compensatórias institucionalizadas, a tomar consciência de quão obstruída está hoje tal possibilidade. Pseudo-atividades são ficções e paródias daquela produtividade que a sociedade, por um lado, reclama incessantemente e, por outro, refreia e não quer muito nos indivíduos. Theodor Adorno, Indústria cultural e sociedade.

Não chamamos de originais àquelas respostas obviamente imitativas ou controladas por estímulos verbais explícitos, como seguir instruções faladas ou escritas. Não temos grande inclinação para chamar de original uma resposta, mesmo que nunca tenha sido feita antes, quando é o resultado de algum procedimento estabelecido de manipulação de variáveis - como nas operações matemáticas de rotina ou no uso de fórmulas silogísticas. (...)

Reservamos o termo "original" para aquelas ideias que resultam de manipulações de 
variáveis que não seguiram uma fórmula rígida, e nas quais as ideias têm outras fontes de probabilidade de emissão.

B.F Skinner, Ciência e comportamento.

\section{détournement}

nm desvio.

Dicionário escolar Michaelis francês-português.

Pode-se usar qualquer elemento, não importa de onde eles são tirados, para fazer novas combinações. As descobertas de poesia moderna relativas à estrutura analógica das imagens demonstram que quando são reunidos dois objetos, não importa quão distantes possam estar de seus contextos originais, sempre é formada uma relação. Restringir-se a um arranjo pessoal de palavras é mera convenção. A interferência mútua de dois mundos de sensações, ou a reunião de duas expressões independentes, substitui os elementos originais e produz uma organização sintética de maior eficácia. Pode-se usar qualquer coisa.

Desnecessário dizer que ninguém fica limitado a corrigir uma obra ou a integrar diversos fragmentos de velhas obras em uma nova; a pessoa pode também alterar o significado desses fragmentos do modo que achar mais apropriado, deixando os imbecis com suas servis referências às "citações". Tais métodos paródicos foram frequentemente usados para obter efeitos cômicos. Mas tal humor é o resultado das contradições dentro de uma condição cuja existência é tida como certa. Como o mundo da literatura quase sempre nos parece tão distante quanto o da Idade da Pedra, tais contradições não nos fazem rir. É então necessário conceber uma fase paródica-séria onde a acumulação de elementos deturnados ${ }^{3}$, longe de contribuir para provocar indignação ou riso em sua alusão a algum trabalho original, expresse nossa indiferença para com um inexpressivo e desprezível original, e se interesse em fazer uma certa sublimação.

(...)

As tendências para o deturnamento que podem ser observadas na expressão contemporânea são em sua maior parte inconscientes ou acidentais. É na indústria da propaganda, mais do que na decadente produção estética, onde estão os melhores exemplos. Podemos em primeiro lugar definir duas categorias principais de elementos deturnados, levando em consideração se o ajuntamento vem ou não acompanhado por correções inseridas nos originais. Temos aqui deturnamentos secundários e deturnamentos enganosos. O deturnamento secundário é o deturnamento de um elemento que não tem nenhuma importância em si mesmo e que tira todo seu significado do novo contexto em que foi colocado. Por exemplo, um recorte de jornal, uma frase neutra, uma fotografia comum. $O$ deturnamento enganoso, também chamado deturnamento de proposição-premonitória, é

3 Optou-se por aportuguesar a palavra francesa détournement, já que no texto são utilizadas muitas variações dela: como verbo, substantivo, adjetivo.( N.T.) 
em contraste o deturnamento de um elemento intrinsecamente significante que deriva de um diferente escopo de um novo contexto. Por exemplo, um slogan de Saint-Just ou um trecho de um filme de Eisenstein. Obras extensamente deturnadas são usualmente compostas por uma ou mais séries de deturnamentos enganosos e secundários.

(...)

As distorções introduzidas nos elementos deturnados devem ser tão simples quanto possível, pois o impacto principal de um deturnamento tem relação direta com a lembrança consciente ou semiconsciente dos contextos originais dos elementos. Isto é bem conhecido. Basta simplesmente notar que esta dependência da memória insinua a necessidade de determinar o público alvo antes de inventar um deturnamento. Este é apenas um caso particular de uma lei geral que governa não apenas o deturnamento mas também qualquer outra forma de ação no mundo.

(...)

O título contribui fortemente no deturnamento de uma obra, mas há uma inevitável ação contrária à obra no título. Assim pode-se fazer extenso uso de títulos específicos retirados de publicações científicas ("Biologia Litoral dos Mares Temperados") ou militares ("Combate Noturno de Pequenas Unidades de Infantaria"), ou até mesmo de muitas frases encontradas nos livros ilustrados infantis ("Paisagens Maravilhosas Cumprimentam os Passageiros").

Guy Debord e Gil Wolman, Guia prático para usuários do deturnamento. 

Instruções para a construção de obras 


\section{Unidades Decorativas}

1. Aplique sobre um tijolo de barro de oito furos $(19 \times 29 \times 9 \mathrm{~cm})$ todas as camadas de que são constituídas uma casa, na seguinte ordem: o cimento, a massa corrida, a tinta;

2. Finalize o arranjo acrescentando a decoração [Aqui a exemplificadas por meio de um pequeno quadro de fabricação chinesa adquirido em uma loja de produtos de baixo custo];

3. Escolha quadros que ostentem aquele mesmo tipo de representação de paisagens que vemos estampadas em toda sorte de objetos de uso cotidiano - calendários, capas de cadernos, descanso de telas de computador etc. É importante que as imagens atuem como escapes aos aborrecimentos do dia-a-dia';

4. Repita a operação sobre quantos tijolos desejar.

Observação: Não se esqueça de que cada unidade deve sintetizar todas as dimensões de uma casa: a estrutural, a arquitetônica e a social.

1 ver os verbetes nostalgia (p. 71 ) e vacance (K.D. Hartmann) (p. 73). 


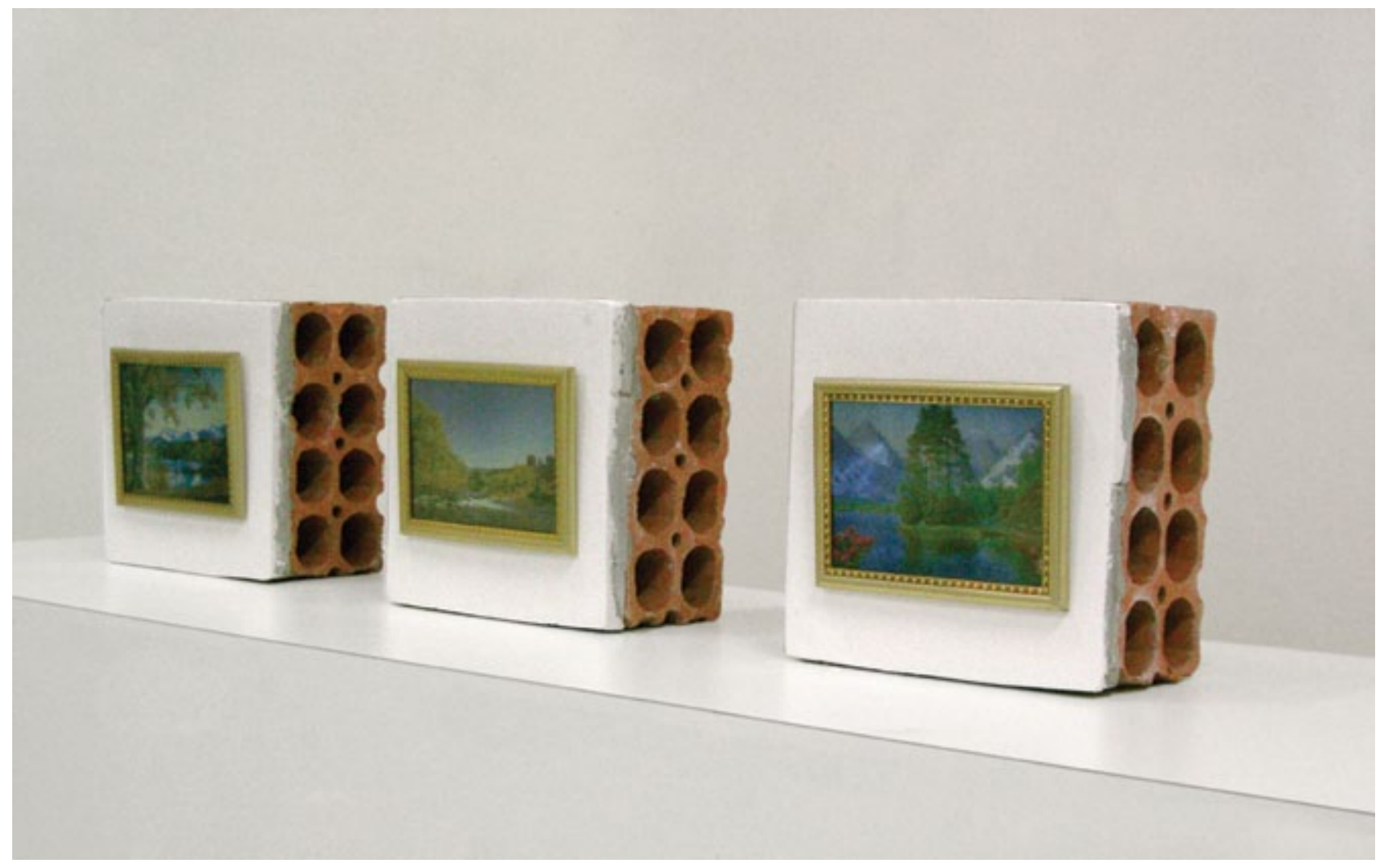




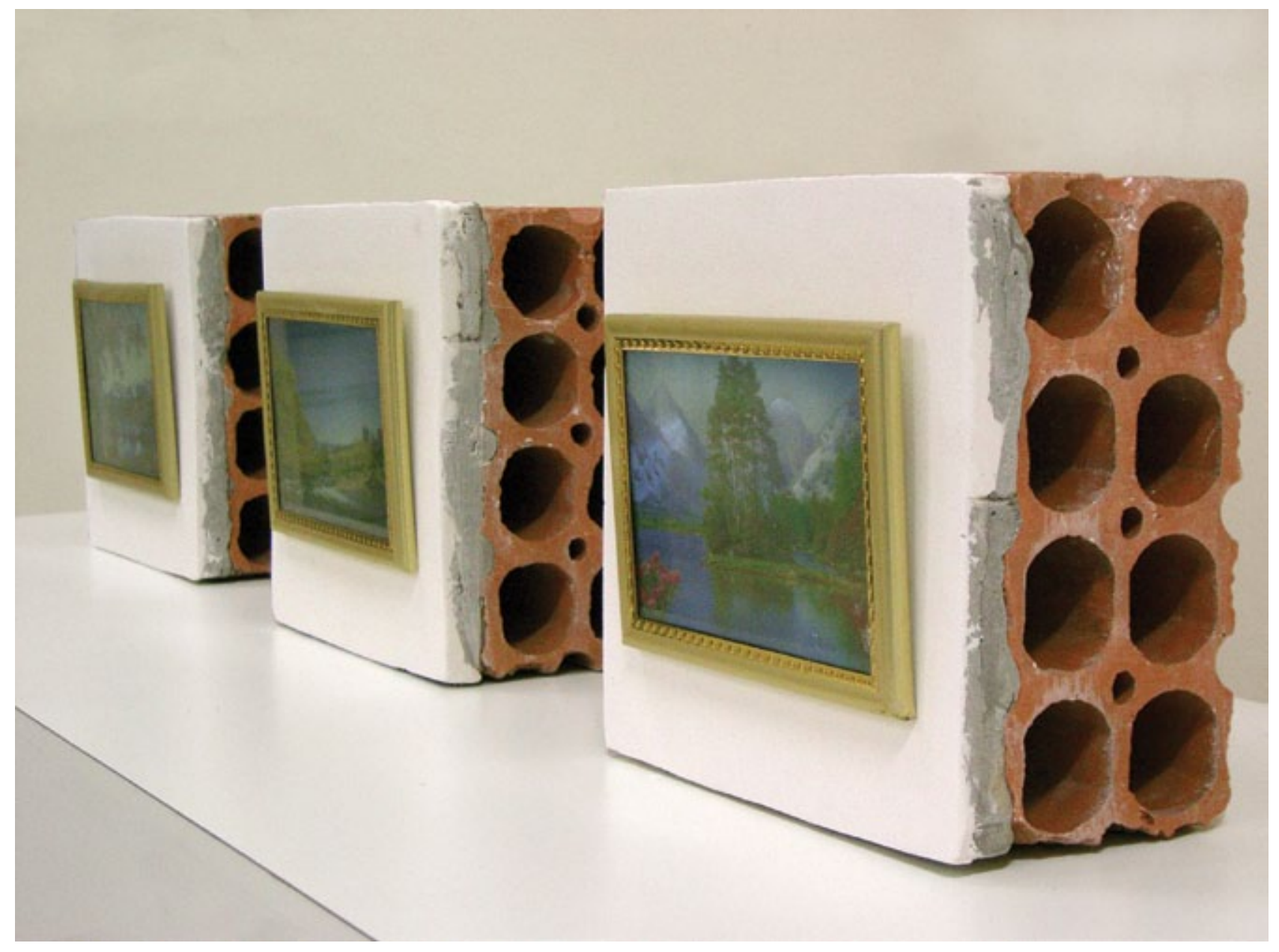




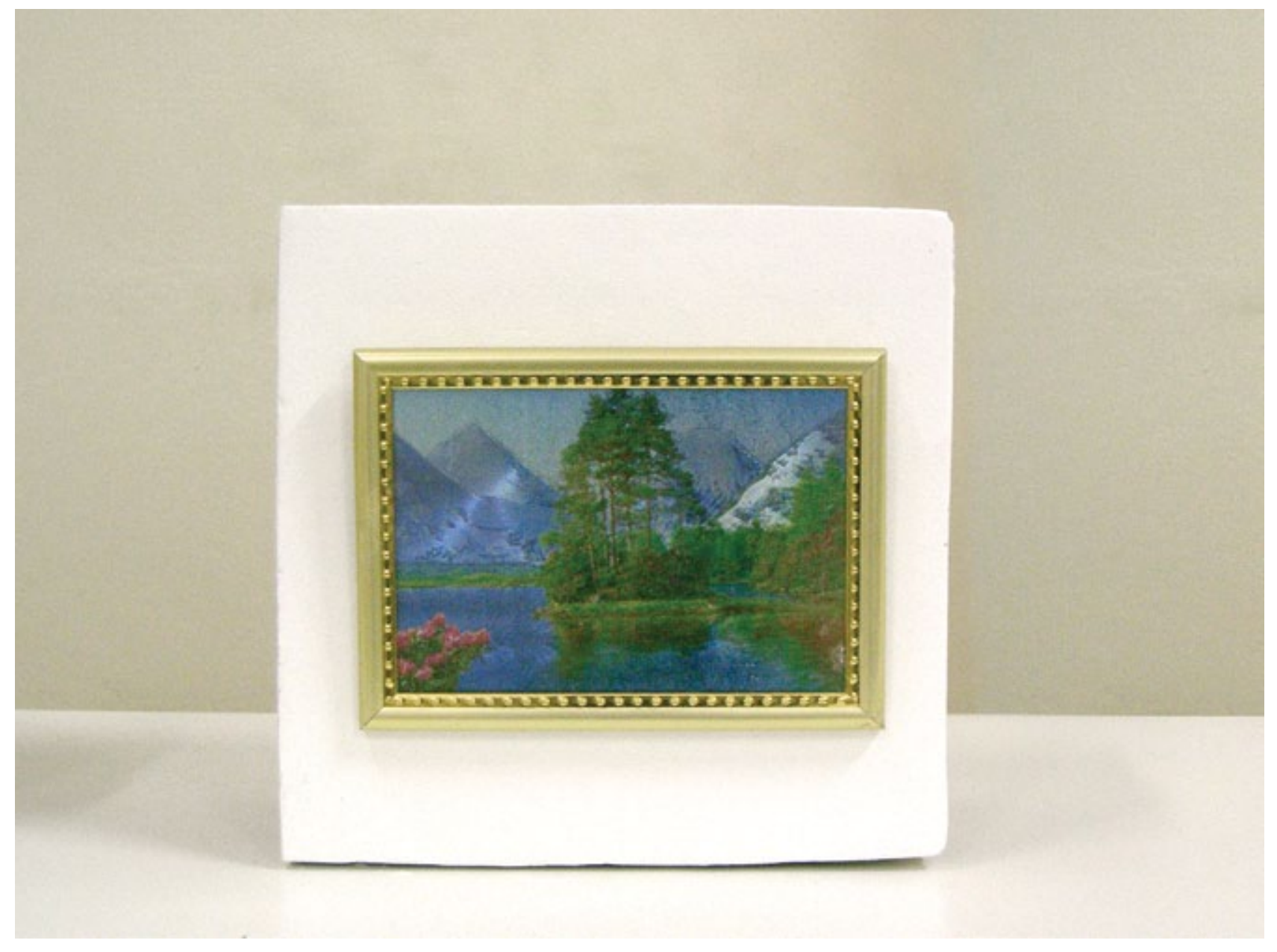




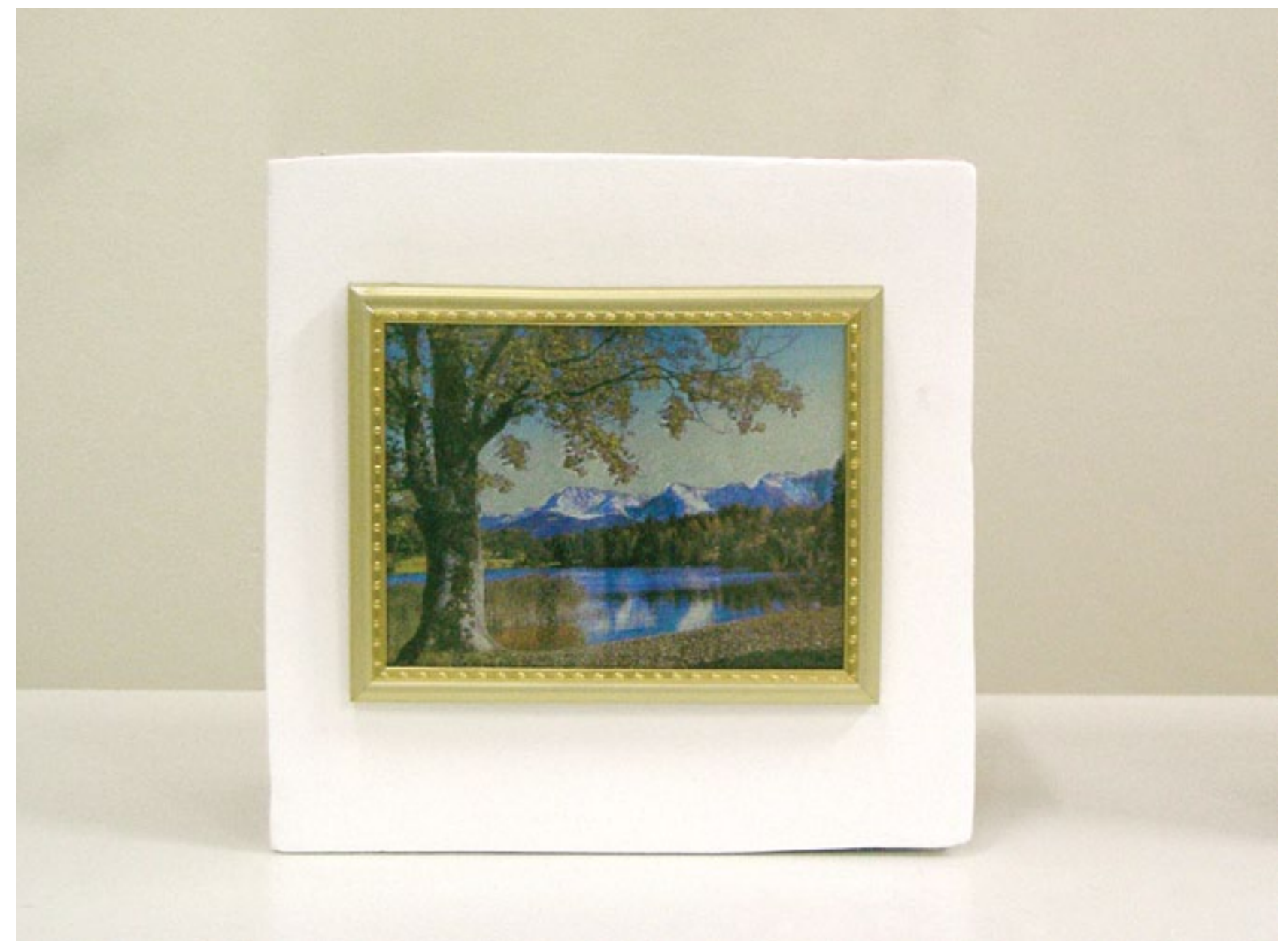




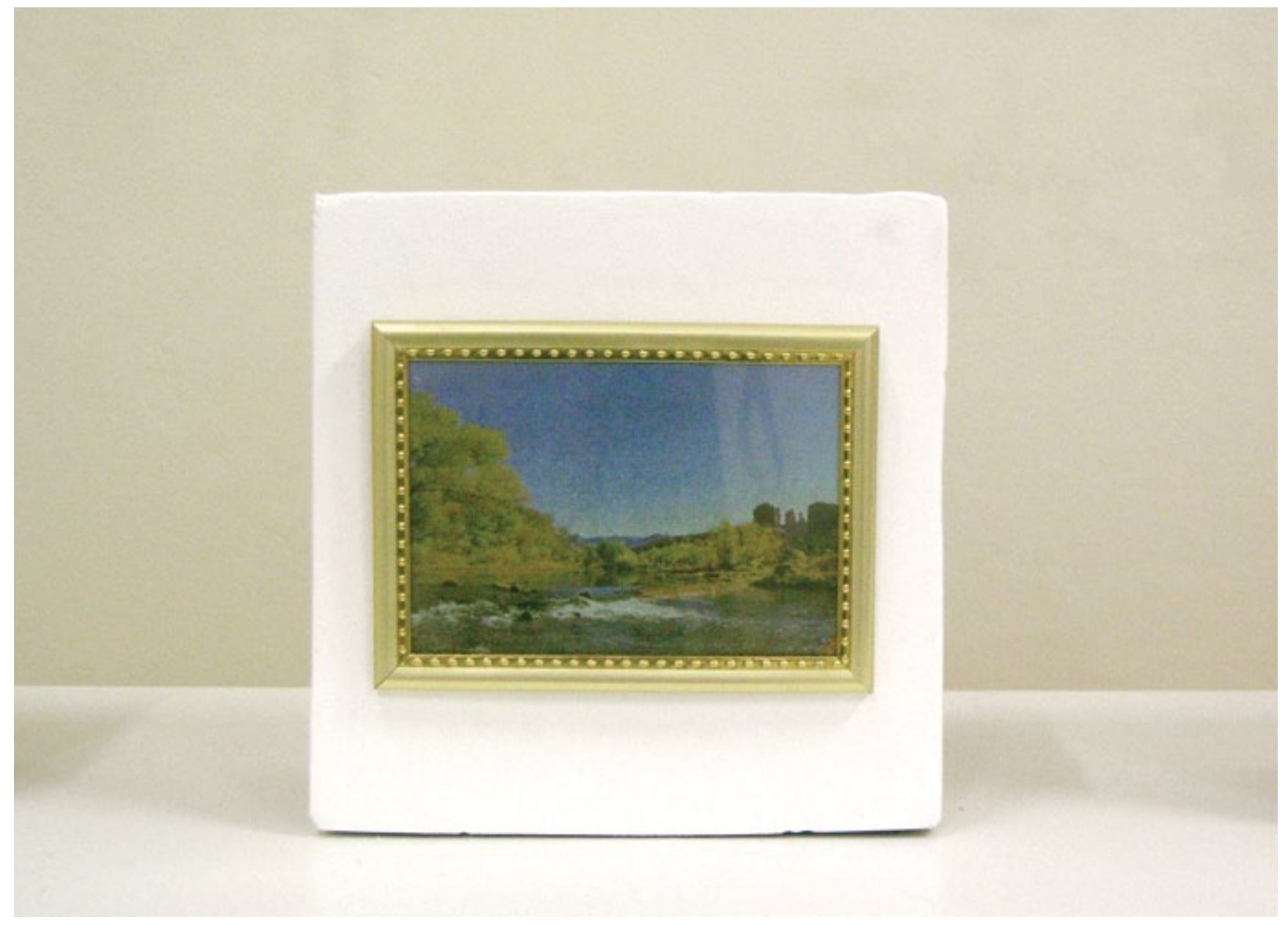




\section{Balneário}

1. Observe o lugar que pretende ocupar. Considere os elementos estruturais, arquitetônicos e decorativos existentes [No exemplo a seguir, havia um galpão com claraboia, piso cerâmico branco, balcão em alvenaria rodeado por um deck de madeira, vasos de cerâmica com palmeiras e vasos de vidro com plantas tropicais];

2. Reorganize os elementos no espaço;

3. Acrescente o mínimo necessário para dar um novo significado aos elementos preexistentes [Aqui, foram apenas inseridos refletores com iluminação âmbar sobre as palmeiras, uma paisagem pintada sobre a parede ao fundo e, sobre o piso, uma representação de piscina em vinil adesivo];

4. A pintura na parede deve contextualizar os elementos da cena por meio de uma ilustração econômica, sem grandes preocupações com o grau de realismo. A mera sugestão de uma praia ao longe ou a luz quente do refletor já representam estímulos suficientes para evocar no espectador certo estado de férias ${ }^{2}$.

Observação: Note como procedimentos similares são utilizados em shoppings, halls de edifícios e antessalas de consultórios odontológicos para proporcionar uma sensação de bem-estar e acolhimento aos usuários.

2 ver verbete vacance (p. 73). 


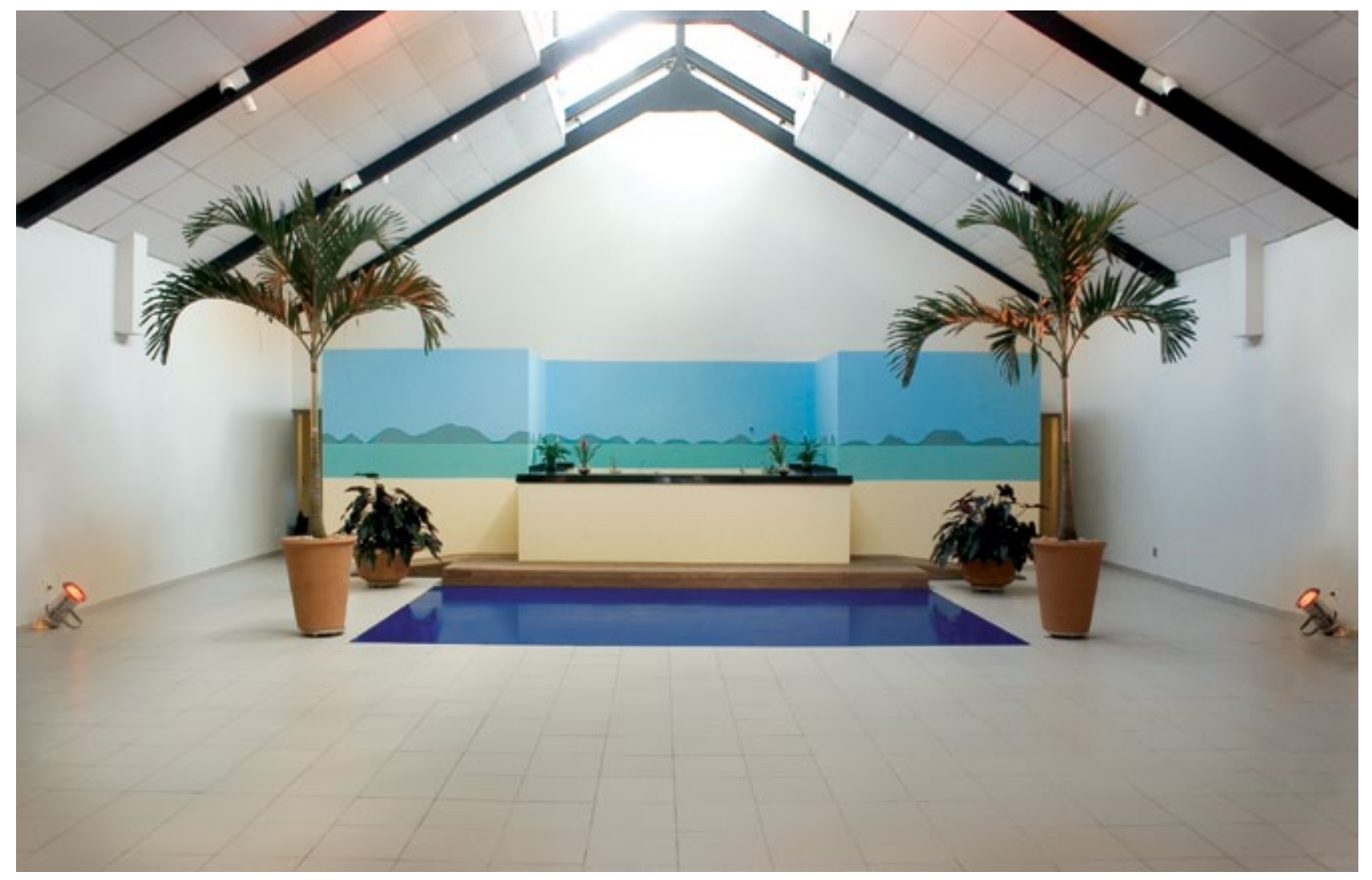




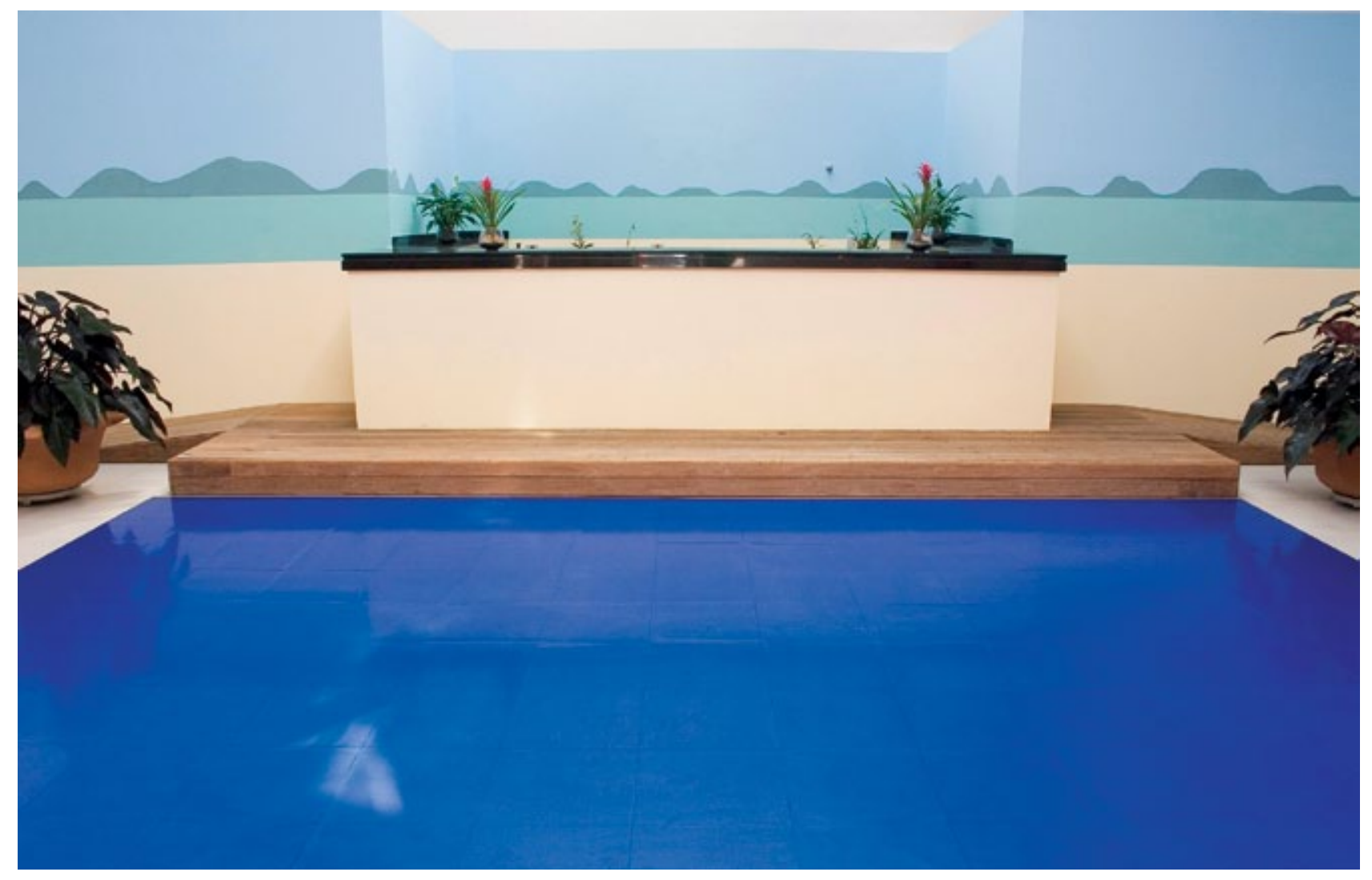




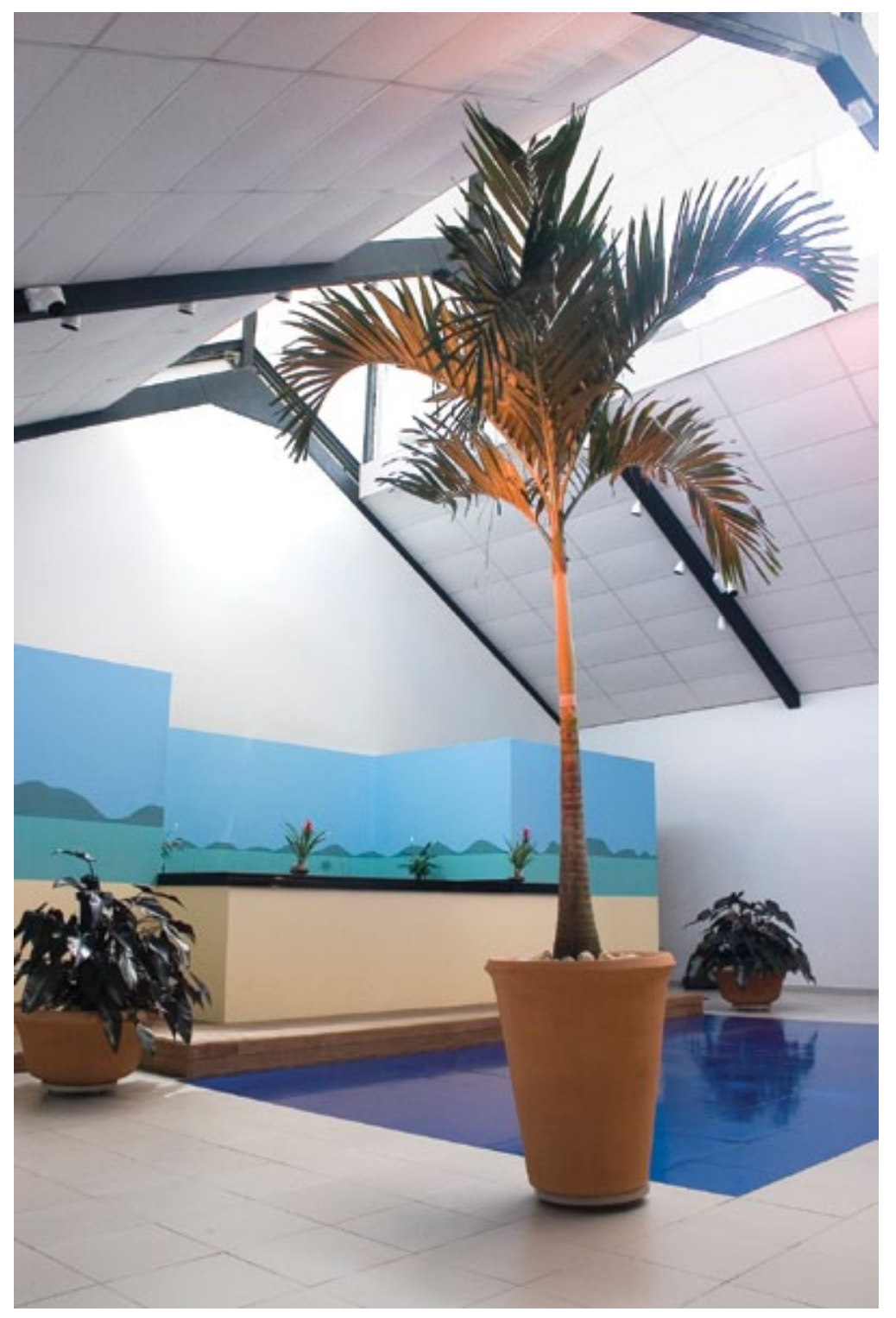




\section{Depois de...}

Antes de começar: Fique atento à situação na qual a obra será desenvolvida. Ela deve responder da melhor forma possível a seu contexto. Por exemplo: se você estiver participando de um programa de múltiplos, organizado por um espaço de arte independente, no qual o valor arrecadado com a venda das obras é revertido para a manutenção das atividades do espaço, será necessário desenvolver um objeto sedutor, capaz - por suas próprias qualidades, e não pelo apelo filantrópico - de despertar o desejo de ser levado para casa.

1. Escolha como tema uma imagem clichê associada à paisagem. É importante selecionar uma composição paisagística que habite o imaginário coletivo relacionado a certo sentimento de nostalgia ${ }^{3}$. Como veremos, esse sentimento depois se estenderá ao objeto produzido, emprestando a ele uma simpatia, um conforto, pelo fato de a imagem já ter sido vista inúmeras vezes;

2. Trace uma estratégia para o objeto: ele deve ser capaz de se infiltrar no domicílio, encaixandose na categoria "representação de paisagem em ambiente doméstico", dentro da qual geralmente figuram pinturas, pôsteres e outros objetos de decoração;

3. Projete um objeto múltiplo, com tiragem de 40 exemplares idênticos, que possam ser dispostos individualmente ou lado a lado, formando uma grande linha;

4. O nome da obra deverá responder à configuração escolhida [No exemplo a seguir, o título do objeto é Depois de..., quando há apenas um deles, e Depois de depois de depois de depois de..., quando o objeto se repete]. A expressão deve se replicar de acordo com o número de objetos dispostos em linha;

5. Disponha-os em linha e receba os potenciais colecionadores. Explique a eles que o tamanho de seu horizonte particular dependerá da quantidade de objetos que adquirirem.

Dica: Ao escolher a empresa que irá confeccionar os múltiplos, dê preferência àquelas com experiência na confecção de displays de cigarros. Diante da proibição de divulgar seus produtos na mídia, o setor ficou limitado a anunciar em pontos de venda como bares e padarias. Os displays produzidos por essas empresas mostram-se muito eficientes em atrair a atenção de clientes.

3 ver verbete nostalgia (p. 71). 


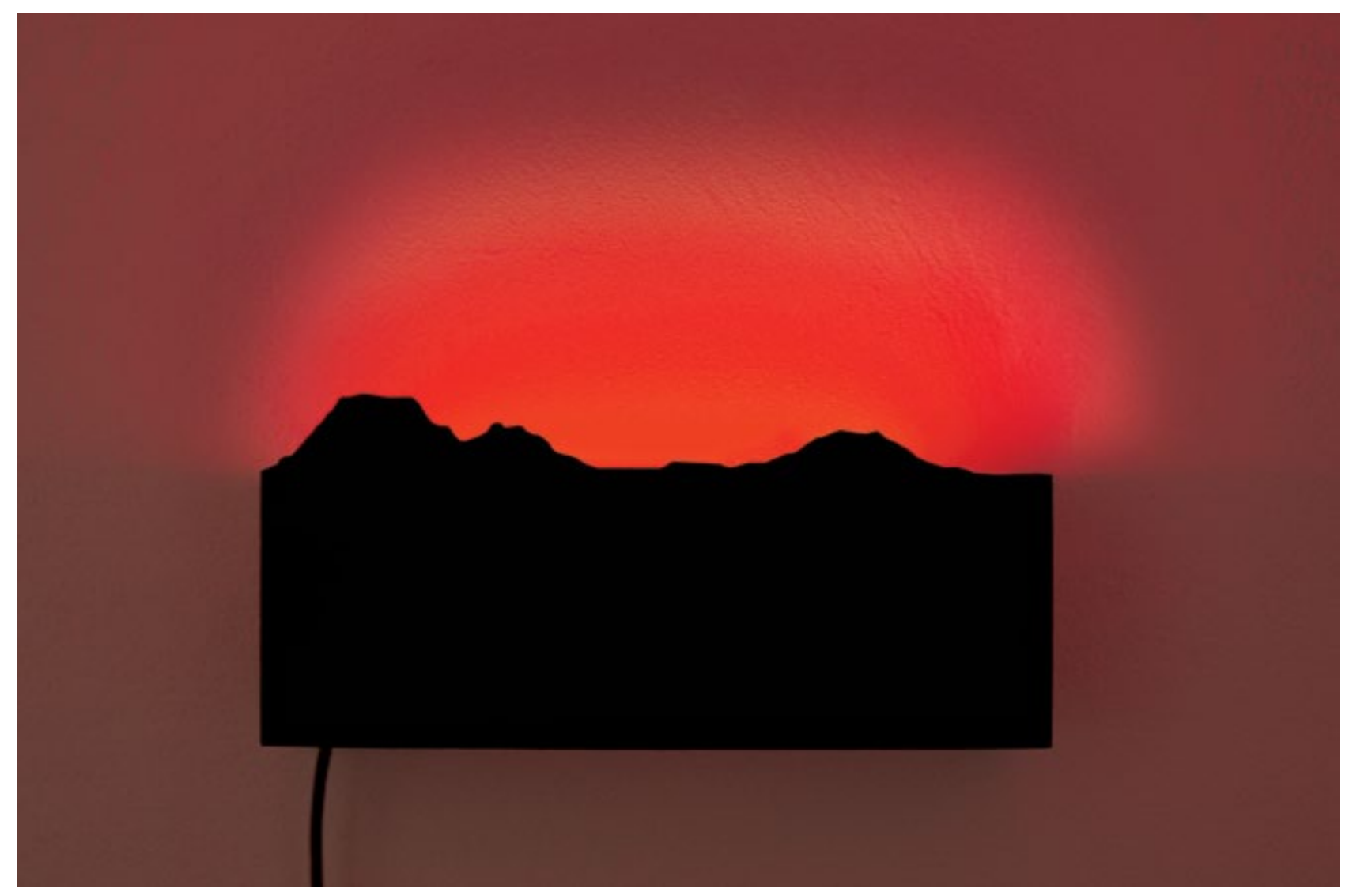




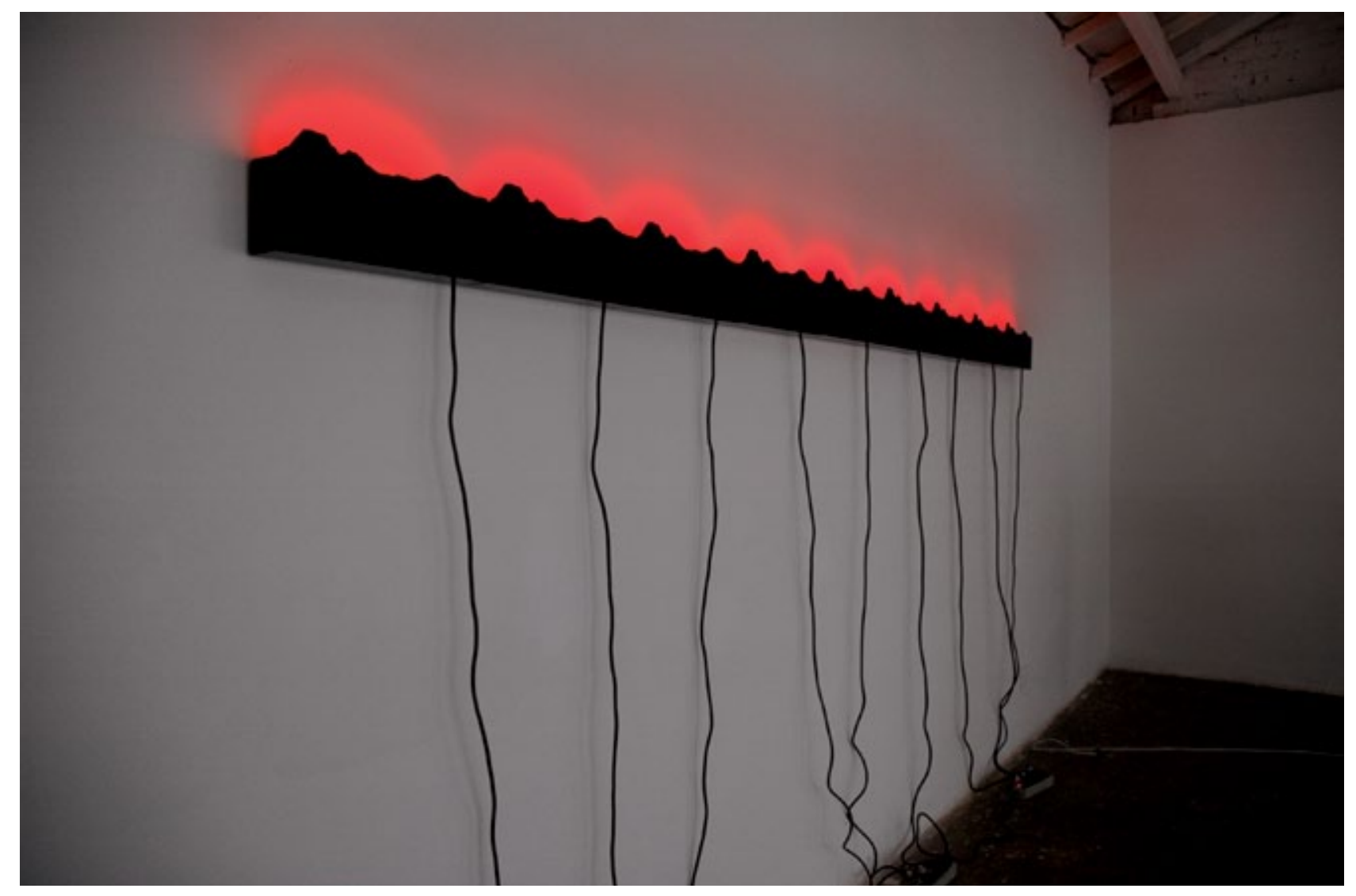




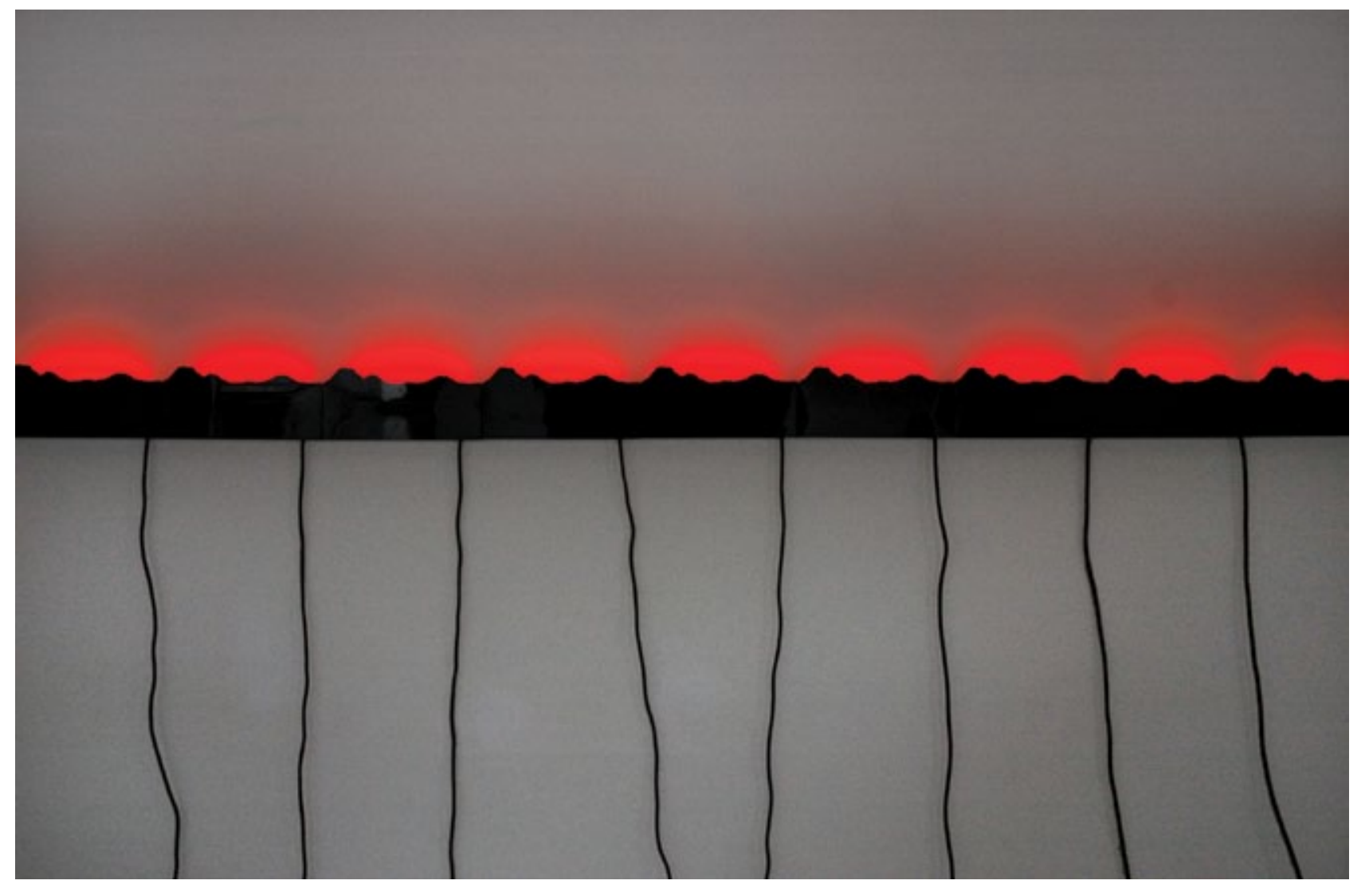




\section{Café Vacance}

1. Selecione como local de intervenção um estabelecimento em funcionamento [A título de exemplo, escolhemos o café que funcionava unidade da Funarte em São Paulo];

2. Escolha um novo nome fantasia para esse espaço. Lembre-se que o nome fantasia deve ser rico em associações, imagens e significações em diversos níveis";

3. Faça uma pesquisa iconográfica na internet digitando a palavra selecionada. Procure identificar as imagens recorrentes associadas ao nome escolhido [Para a pesquisa feita com a palavra vacance, foram obtidas muitas imagens de guarda-sóis listrados] $]^{5}$;

4. Escolha a imagem mais recorrente entre as encontradas. Torne-a ícone de seu estabelecimento e a utilize como matéria principal da intervenção;

5. Encontre uma maneira gentil de convidar o espectador-cliente a entrar e usufruir dos serviços oferecidos. [No Café Vacance, o toldo desce ao chão e torna-se um tapete vermelho, que convida o espectador a ficar à vontade e tomar um drinque ${ }^{6}$;

6. Após o período determinado para a exposição, restitua a função original do estabelecimento, retirando sua fantasia.

\footnotetext{
4 ver verbete nome fantasia (p. 75).

5 ver verbete vacance (p. 73).

6 ver lista de cocktails da International Bartender Association no verbete paraíso (p.73).
} 


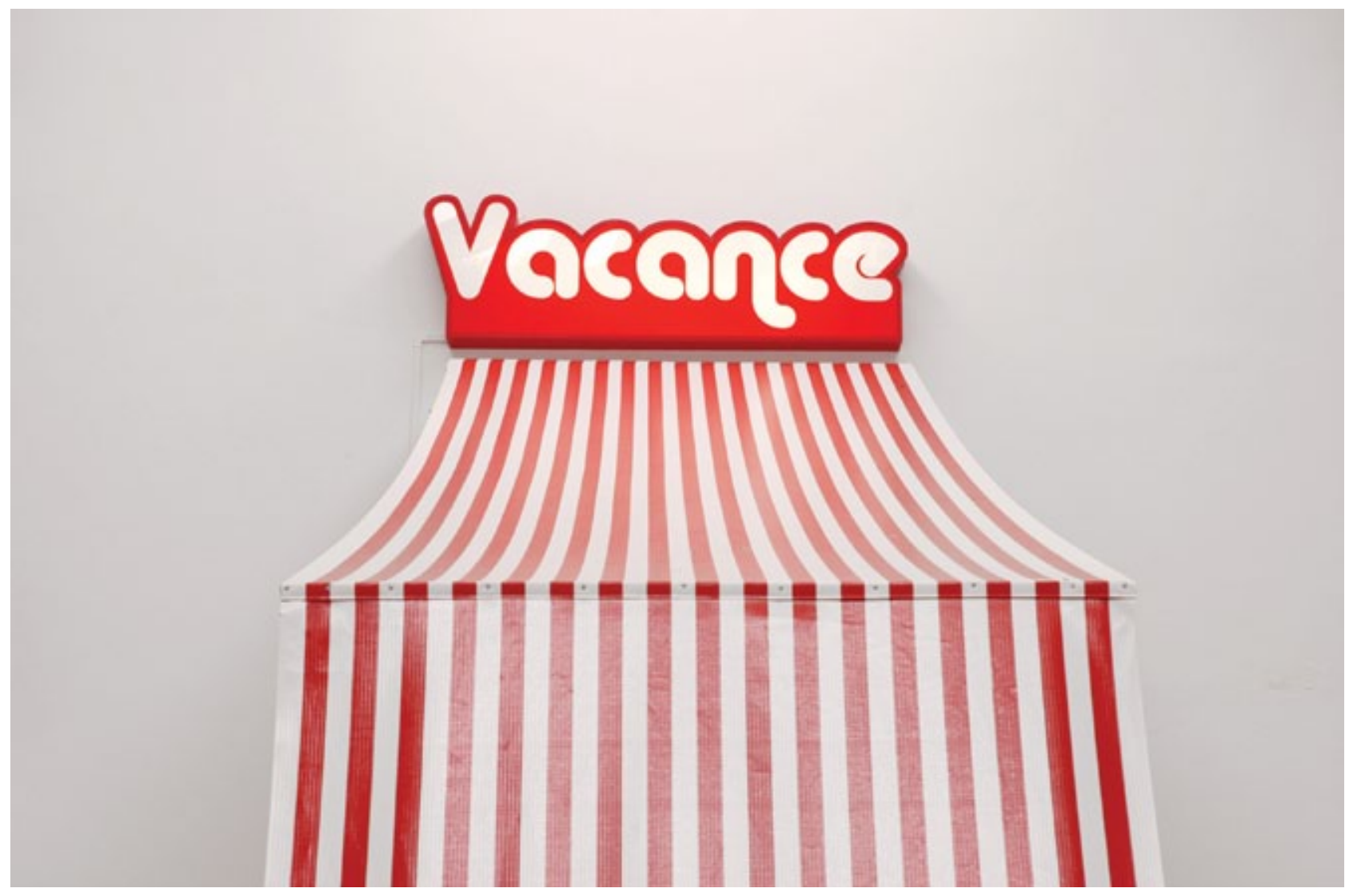




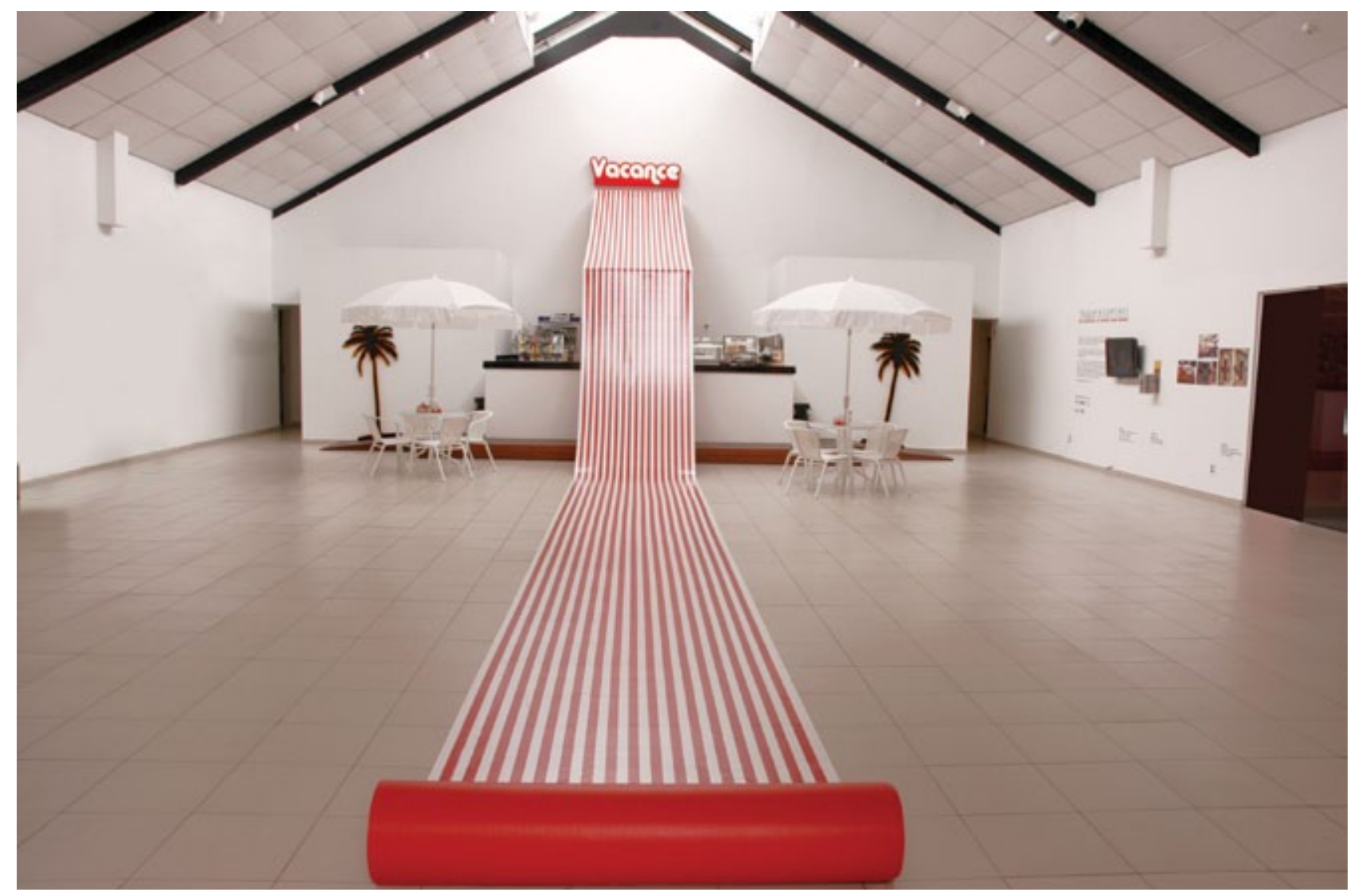




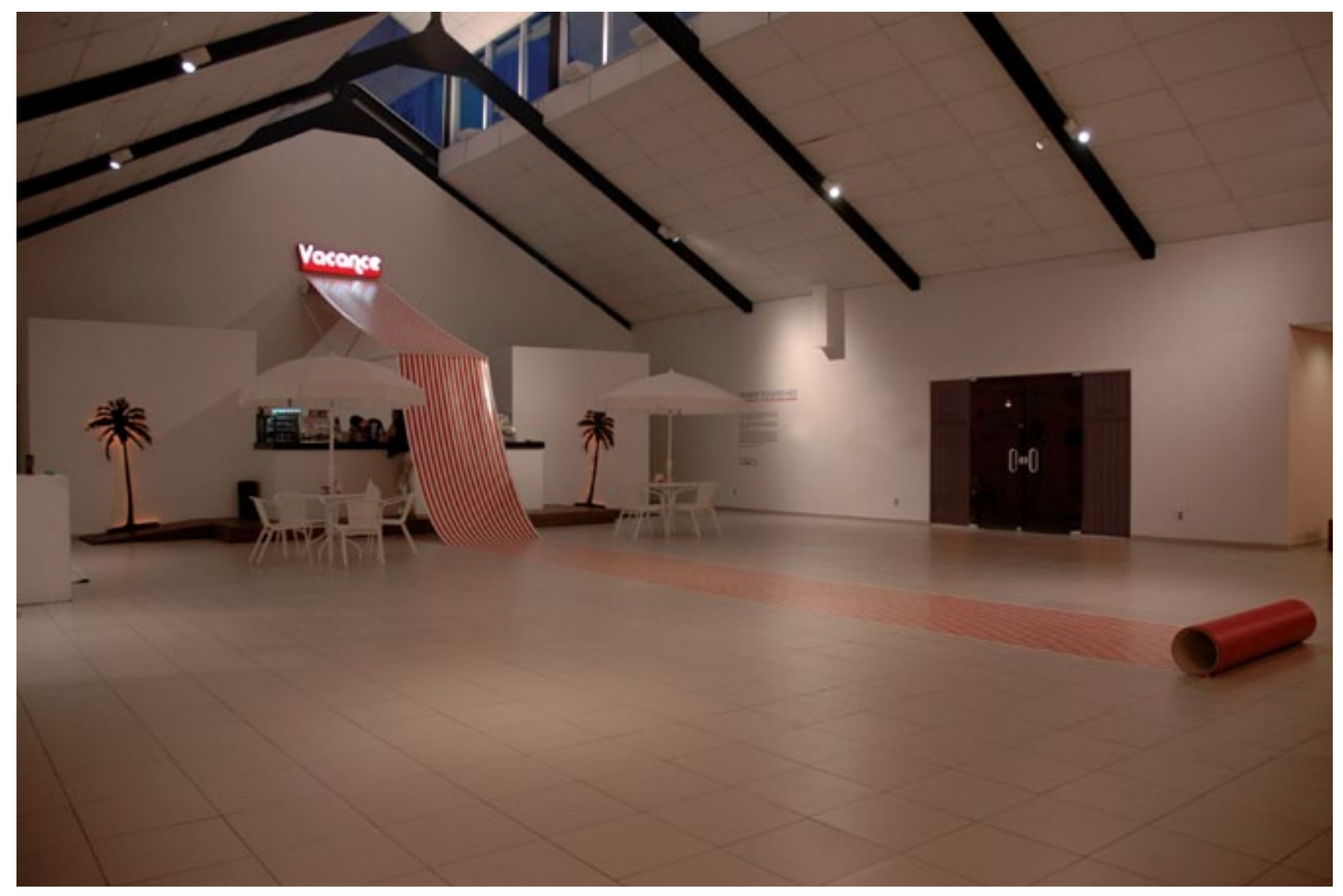




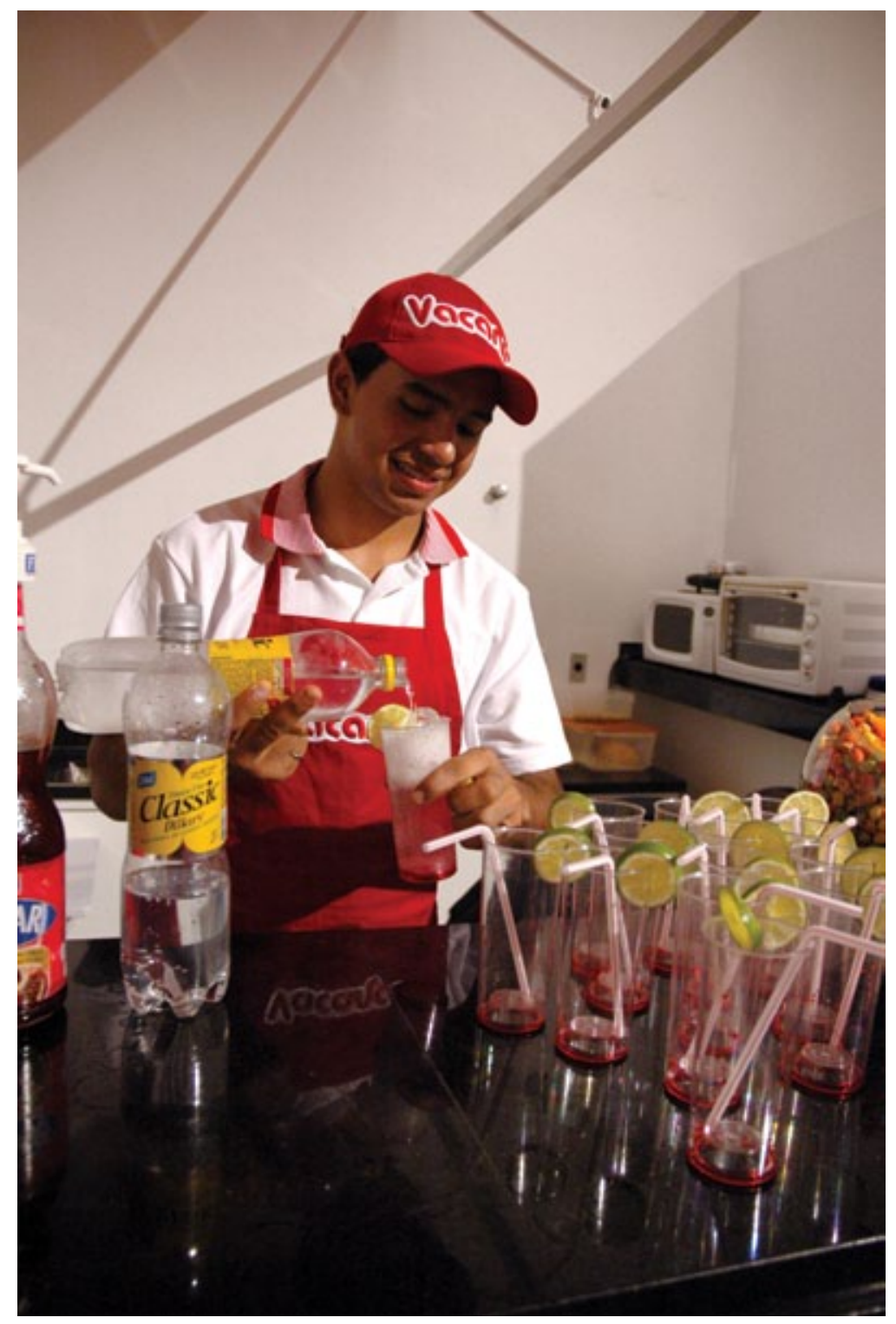




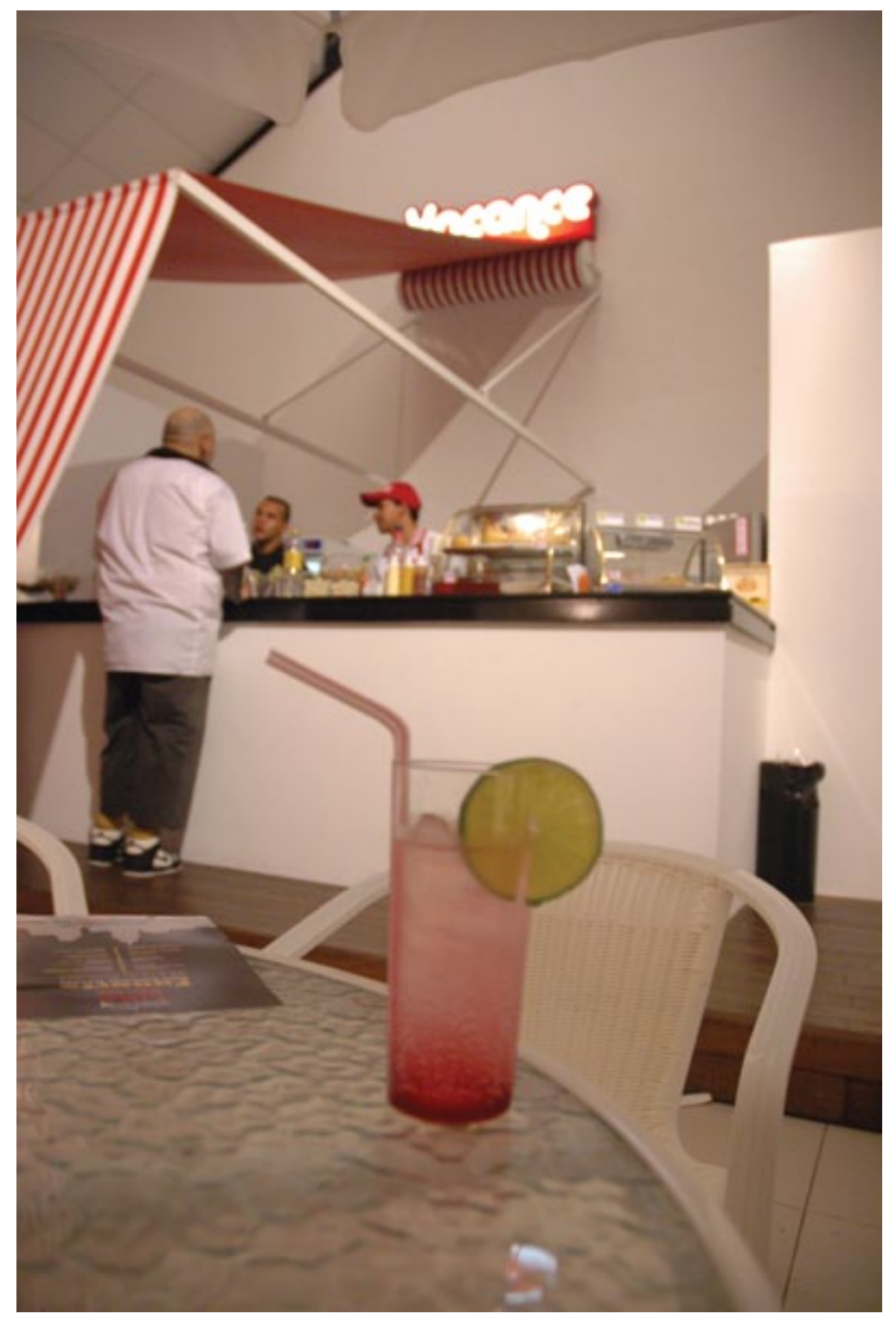




\section{Verão Luminosos}

1. Determine o lugar onde a obra será desenvolvida. Caso escolha ocupar um pequeno galpão industrial em um bairro central da cidade, a construção de uma grande vitrine no interior do imóvel pode ser uma ótima solução expositiva. Instale-a de modo que o transeunte desavisado seja atraído para o interior do galpão sem que se dê conta;

2. Escolha livremente imagens e palavras que façam referência a elementos da paisagem. A opção não deve ser orientada pelo significado literal das palavras, nem pela relação direta das figuras com a natureza. Assim como em exemplos anteriores, as palavras e imagens devem ser escolhidas pelos outros significados agregados a elas em seu uso cotidiano;

3. Desenvolva logotipos a partir das imagens e palavras escolhidas;

4. Projete backlights com as marcas criadas e mande produzi-los em empresa de comunicação visual especializada;

5. Instale os luminosos no interior da vitrine, organizando-os como em um mostruário. Não se deve instalar os luminosos na fachada externa do imóvel;

6. Acenda os luminosos.

Observação: Note como, ao realizar essa sequência de procedimentos, uma transformação acontece: os elementos da paisagem tornam-se signos e, em seguida, objetos que você poderá expor na vitrine. 


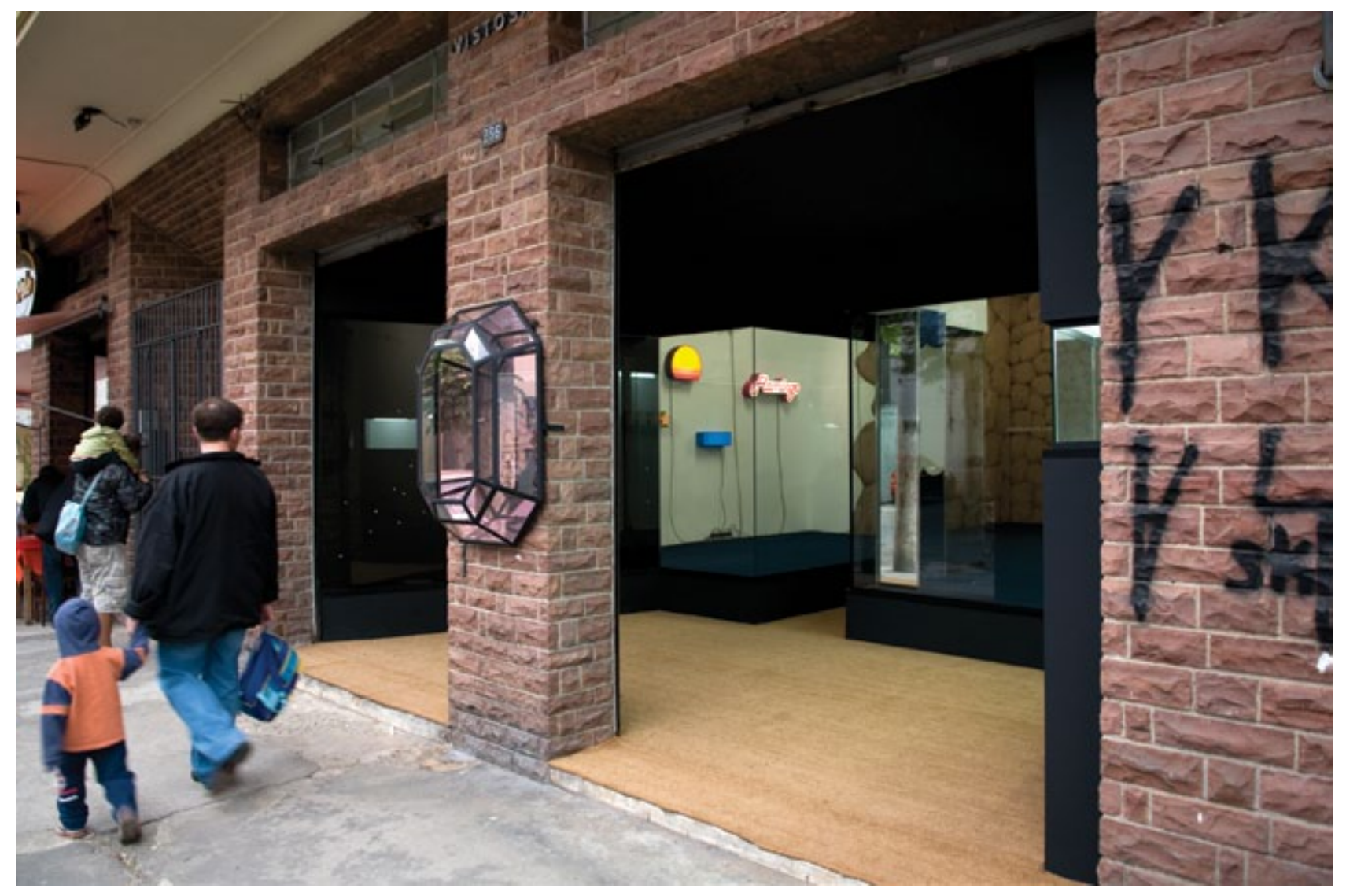




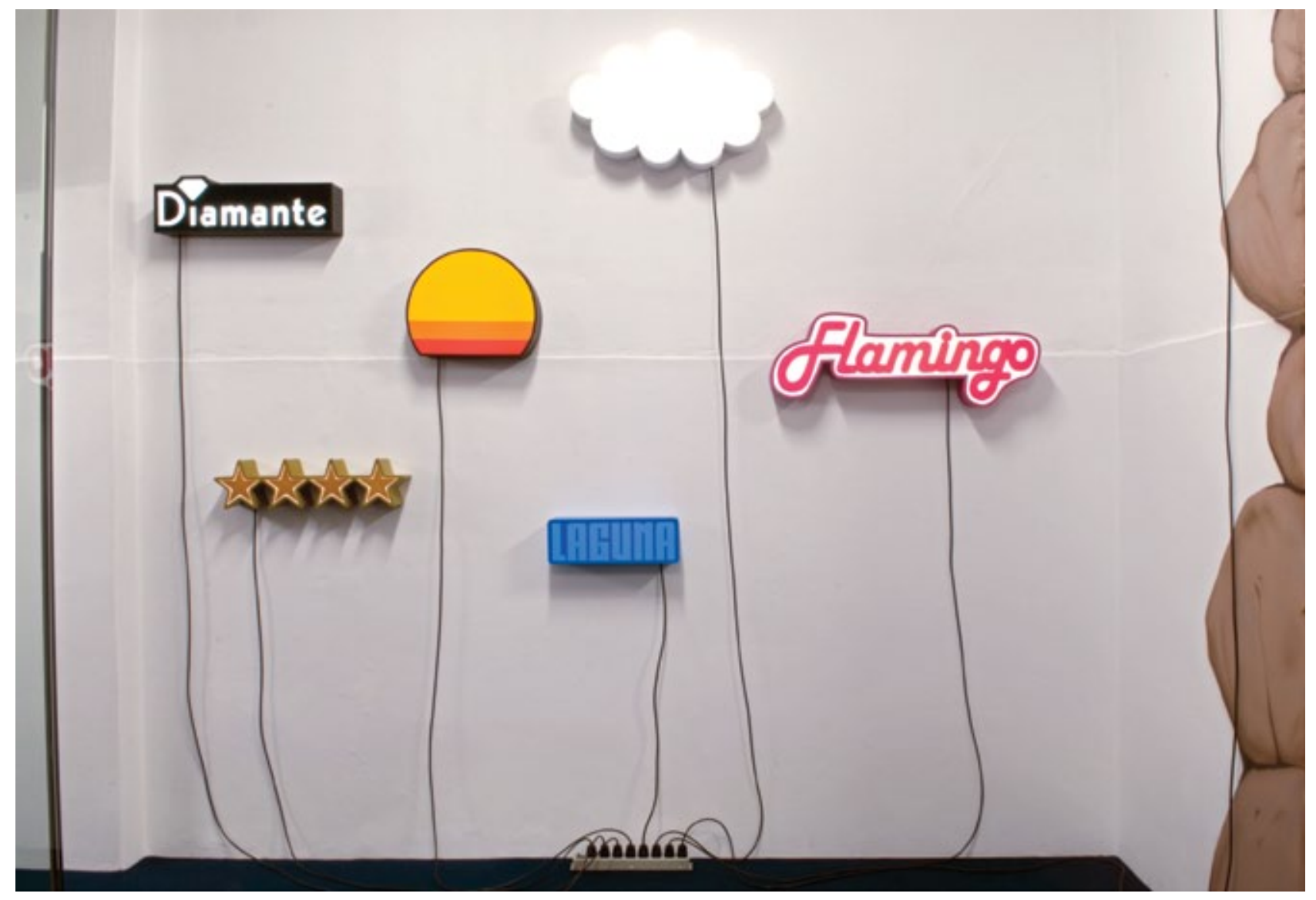




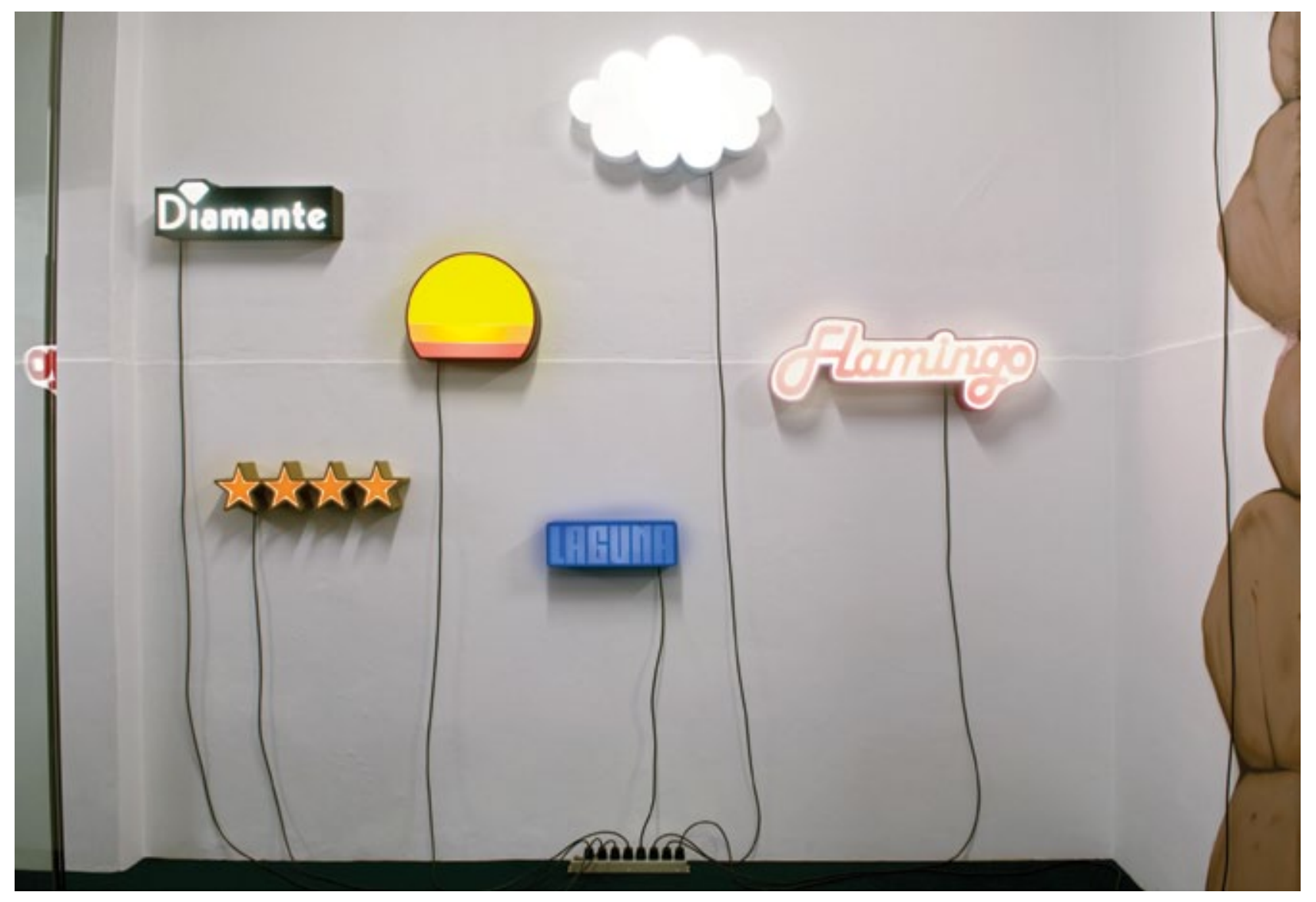




\section{Flórida}

1. Escolha cinco estabelecimentos comerciais com o mesmo nome, na mesma cidade. O nome do estabelecimento deve fazer alusão a uma paisagem turística de verão;

2. Desenhe e recorte silhuetas de palmeiras e flamingos em MDF ou material semelhante. Pinte-as com acabamento refinado fosco preto e instale pequenas lâmpadas no verso das figuras;

3. Transporte os objetos até cada um dos estabelecimentos escolhidos e disponha-os de maneira a compor uma cena;

4. Fotografe.

Observação: É preciso que os objetos dispostos no estabelecimento ou em sua fachada evidenciem o descompasso entre o que o nome designa e o que o lugar realmente é. As composições devem materializar, ainda que temporariamente, o destino e as expectativas que o nome sugere para o lugar. 


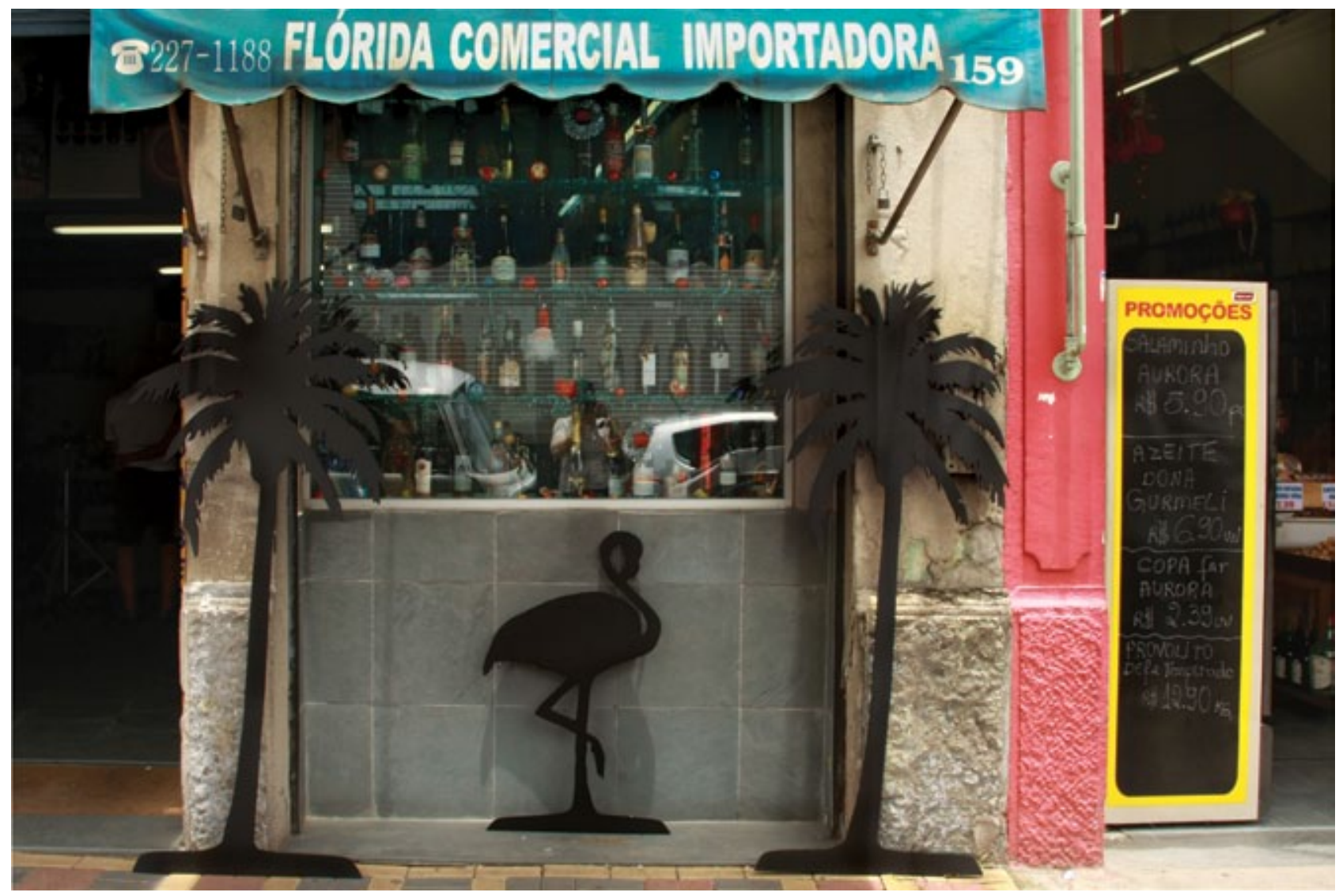




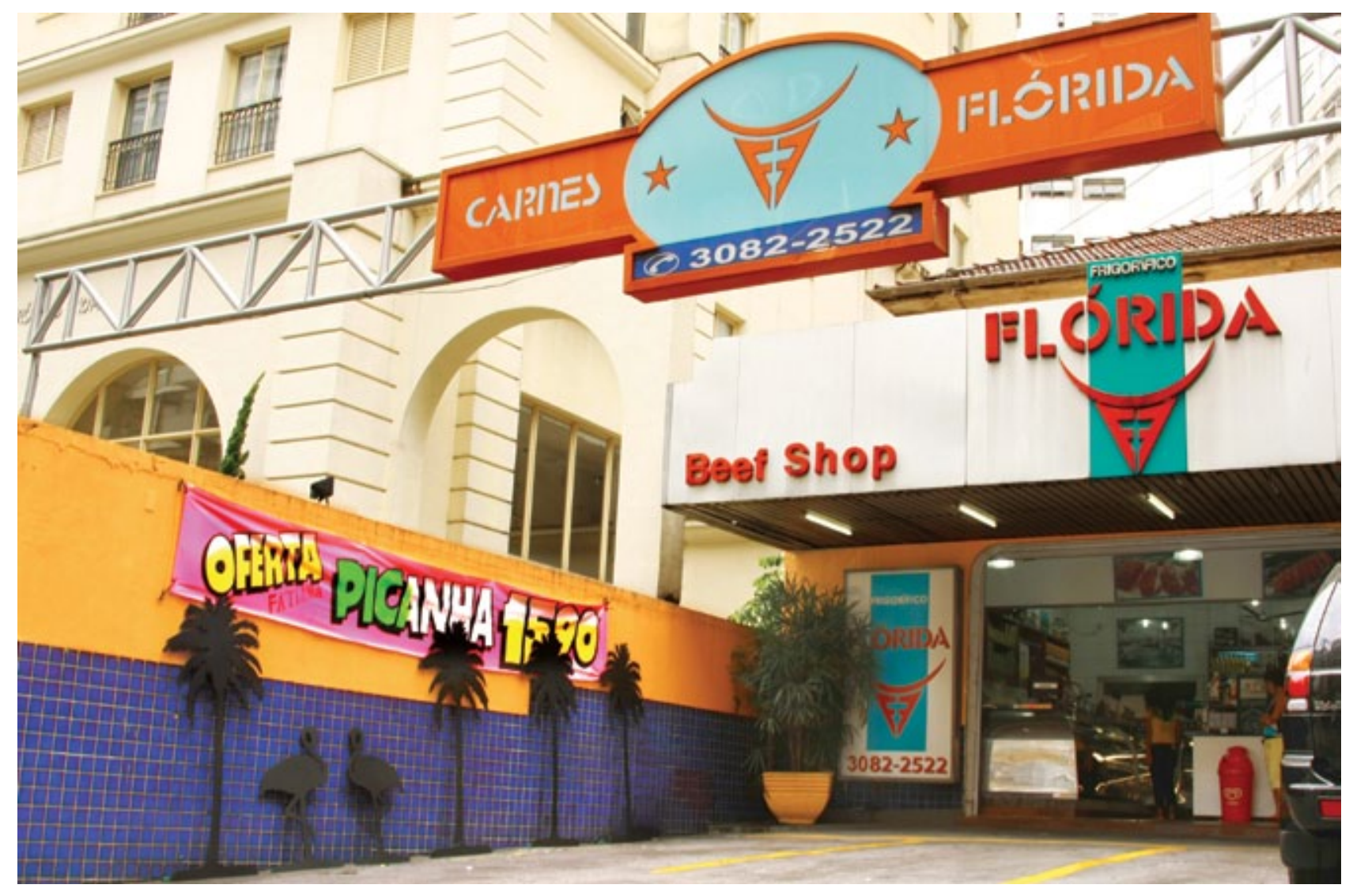




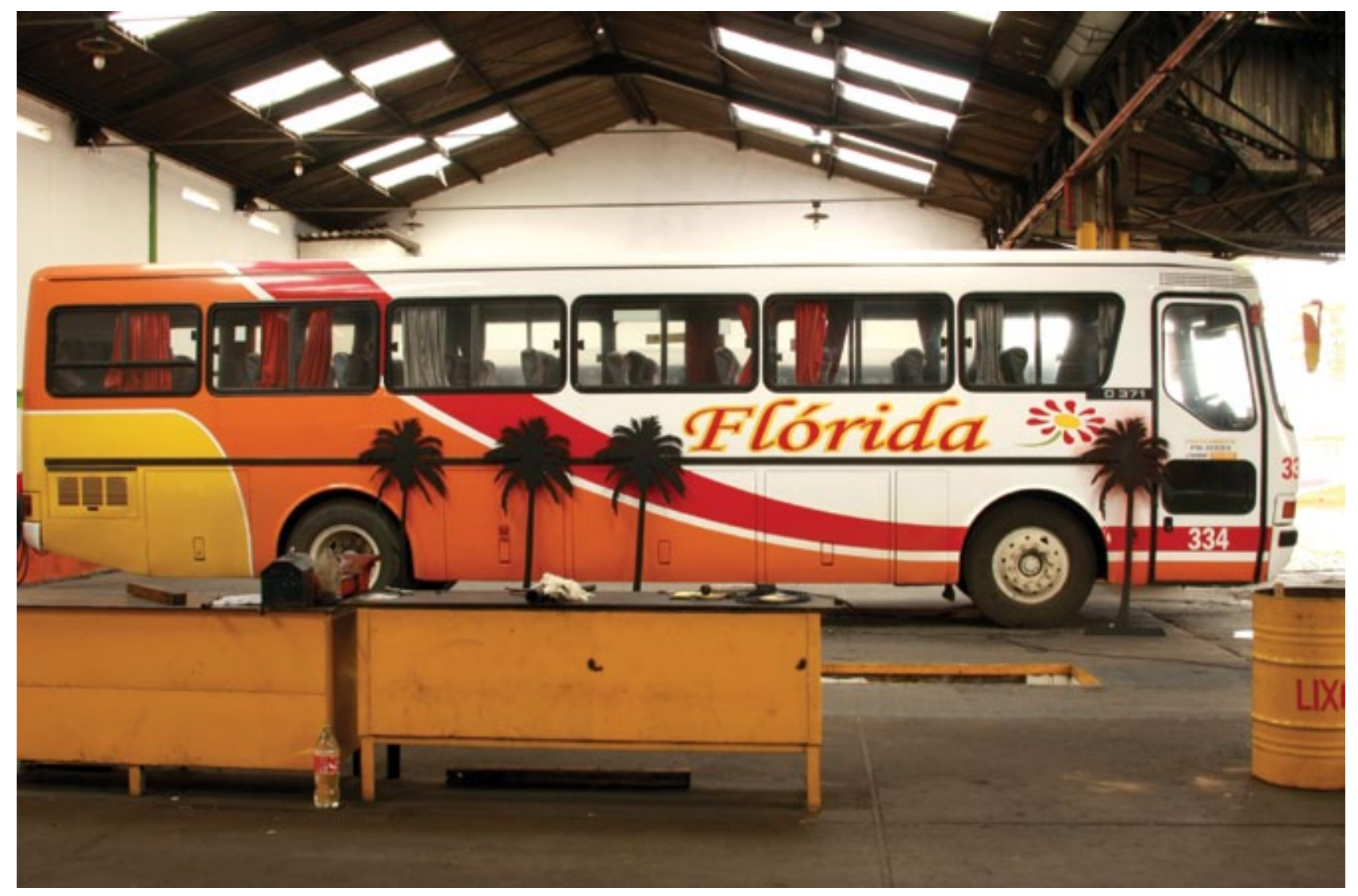




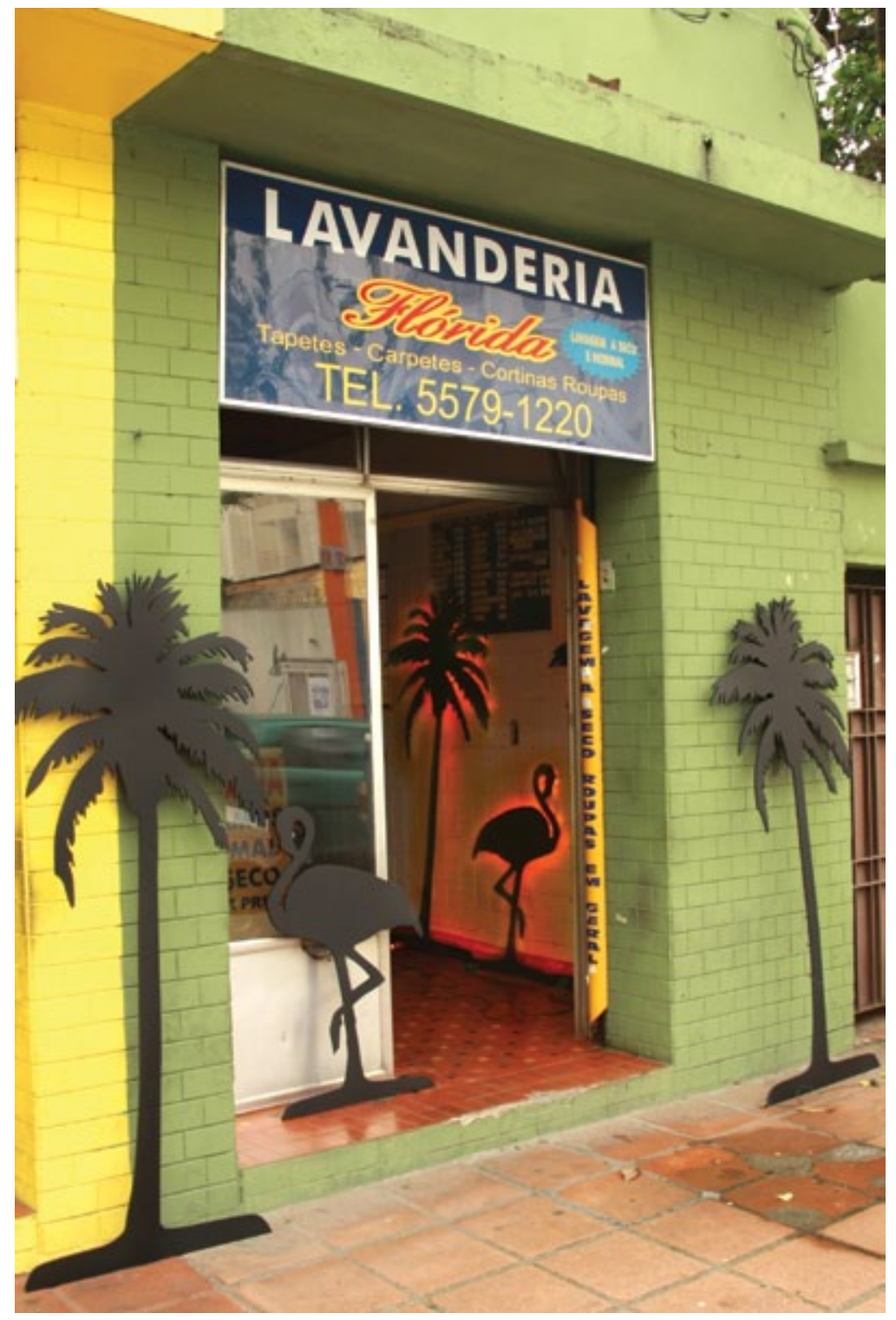




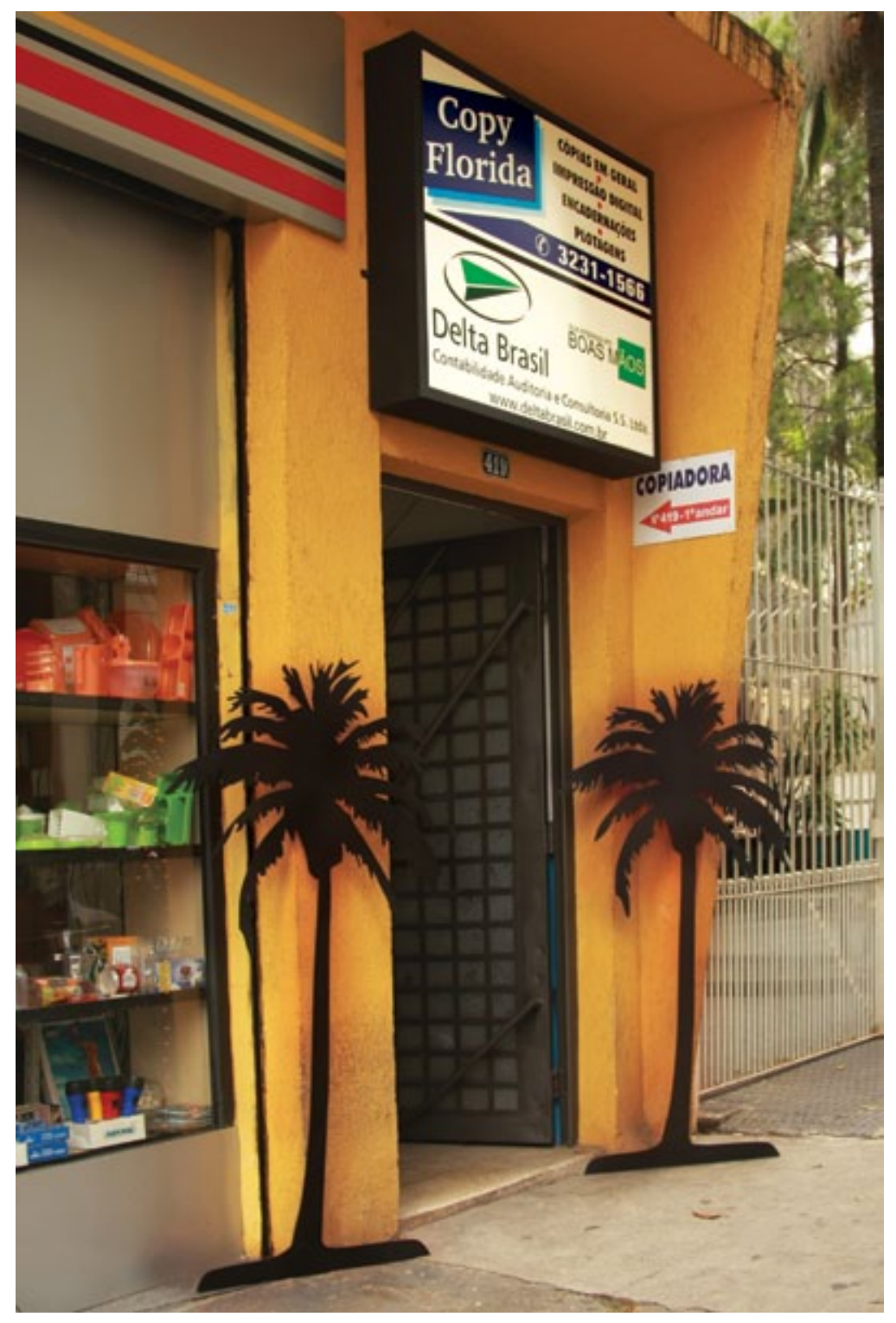




\section{Delivery}

1. Crie uma empresa fictícia com um nome que designe um ponto geográfico conhecido por seu clima gelado. É necessário escolher um lugar onde haja neve constantemente;

2. Crie um logotipo para a empresa;

3. Personalize um carro utilitário com a sinalização criada e carregue-o com flocos de isopor ou material similar;

4. Contrate um funcionário para fazer a entrega. Ele deve vestir uniforme especialmente desenvolvido, em conformidade com a comunicação visual criada para a empresa;

5. O funcionário deve entregar a mercadoria em local de no mínimo $20 \mathrm{~m}^{2}$, onde haja, pelo menos, uma pessoa [O exemplo a seguir aconteceu no pátio de uma galeria de arte, durante um festival de performances];

6. A carga total do veículo deve ser despejada no pátio com o auxílio de uma pá;

7. O funcionário deve partir deixando no pátio a paisagem construída.

Observação: Caso deseje escolher outro material para representar a neve, não se preocupe com propriedades como temperatura e textura. Seja apenas rigoroso quanto à aparência do material para que corresponda ao máximo com a paisagem original ${ }^{7}$.

7 ver verbete trompe-l'oeil (p. 67). 


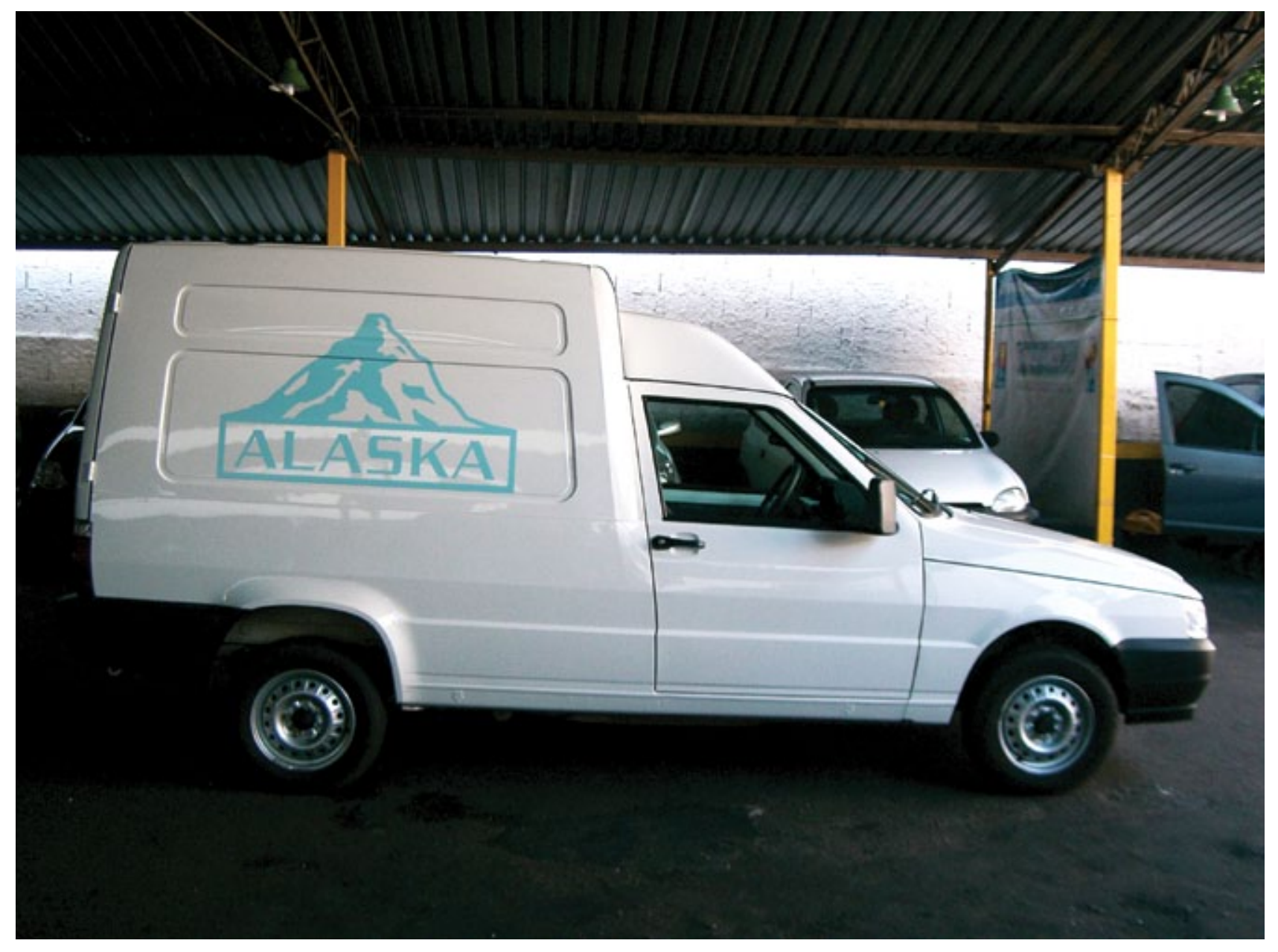




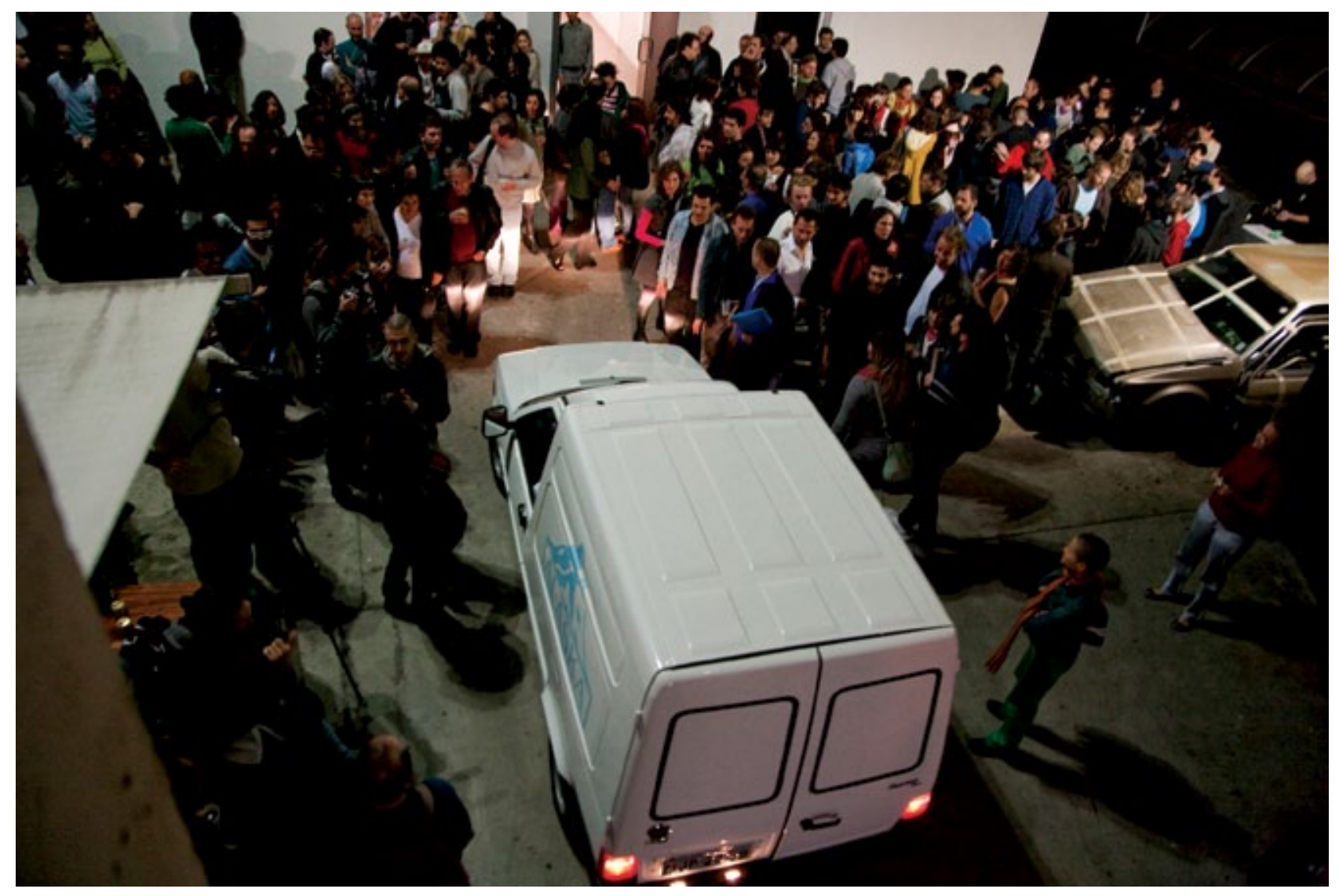




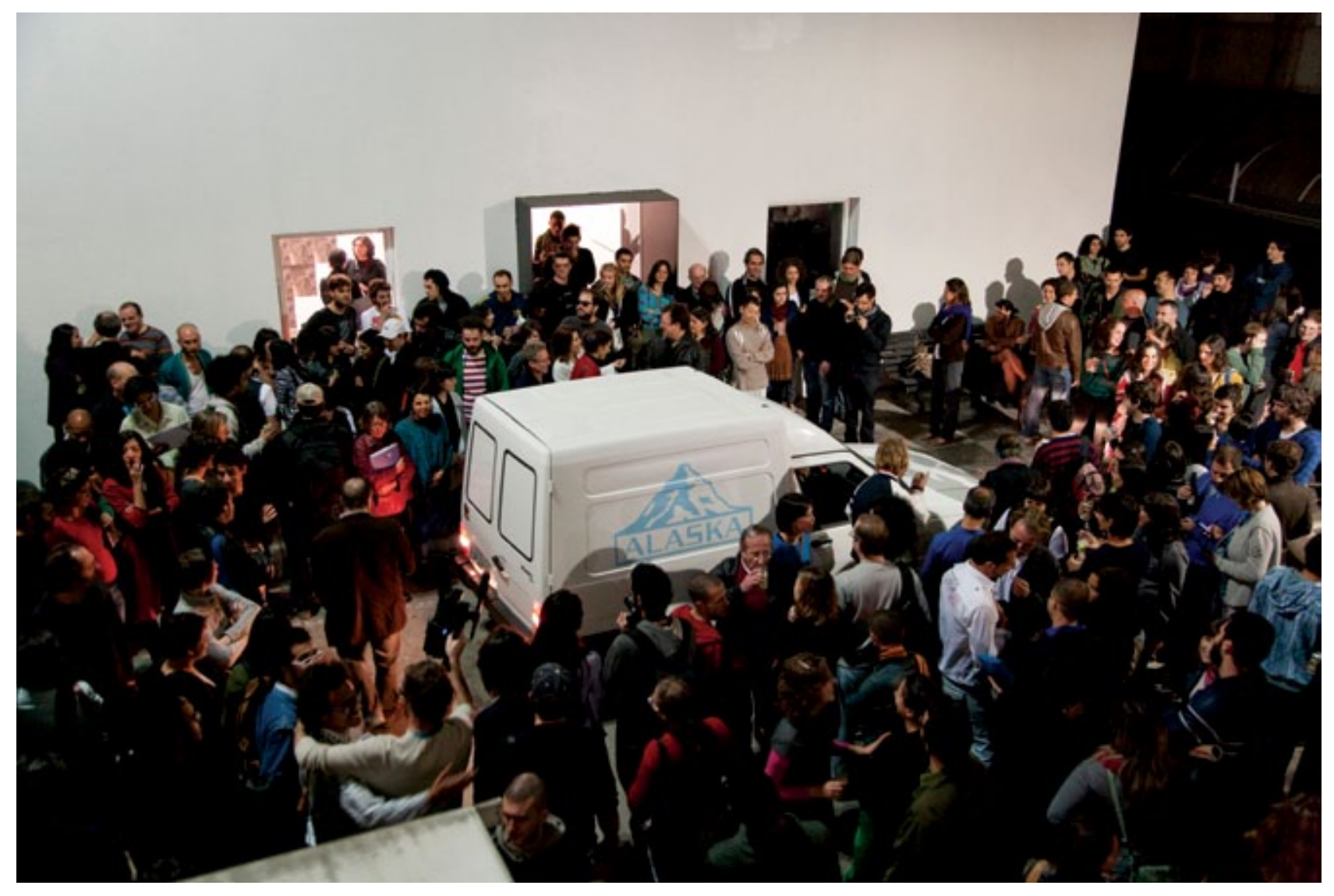




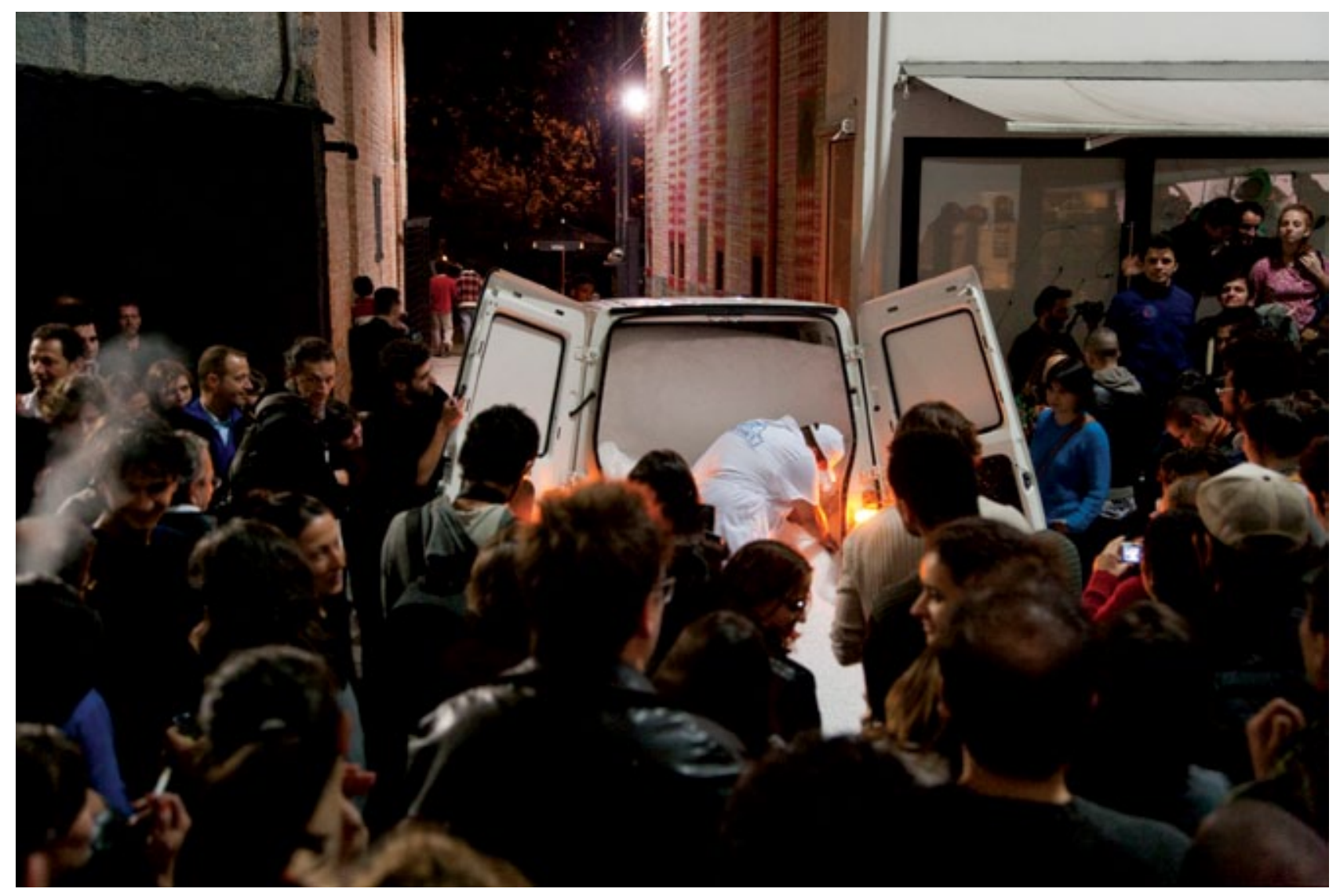




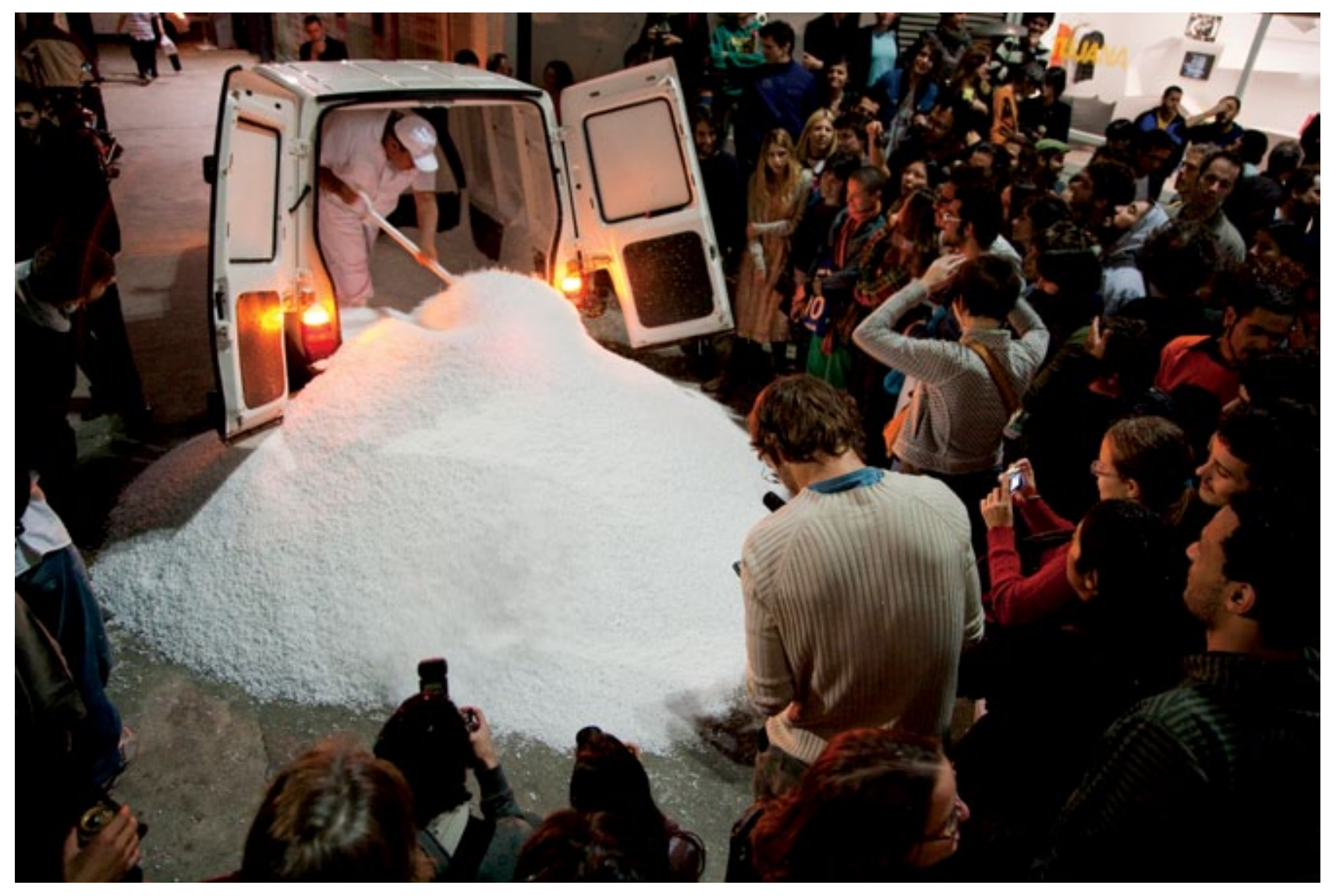




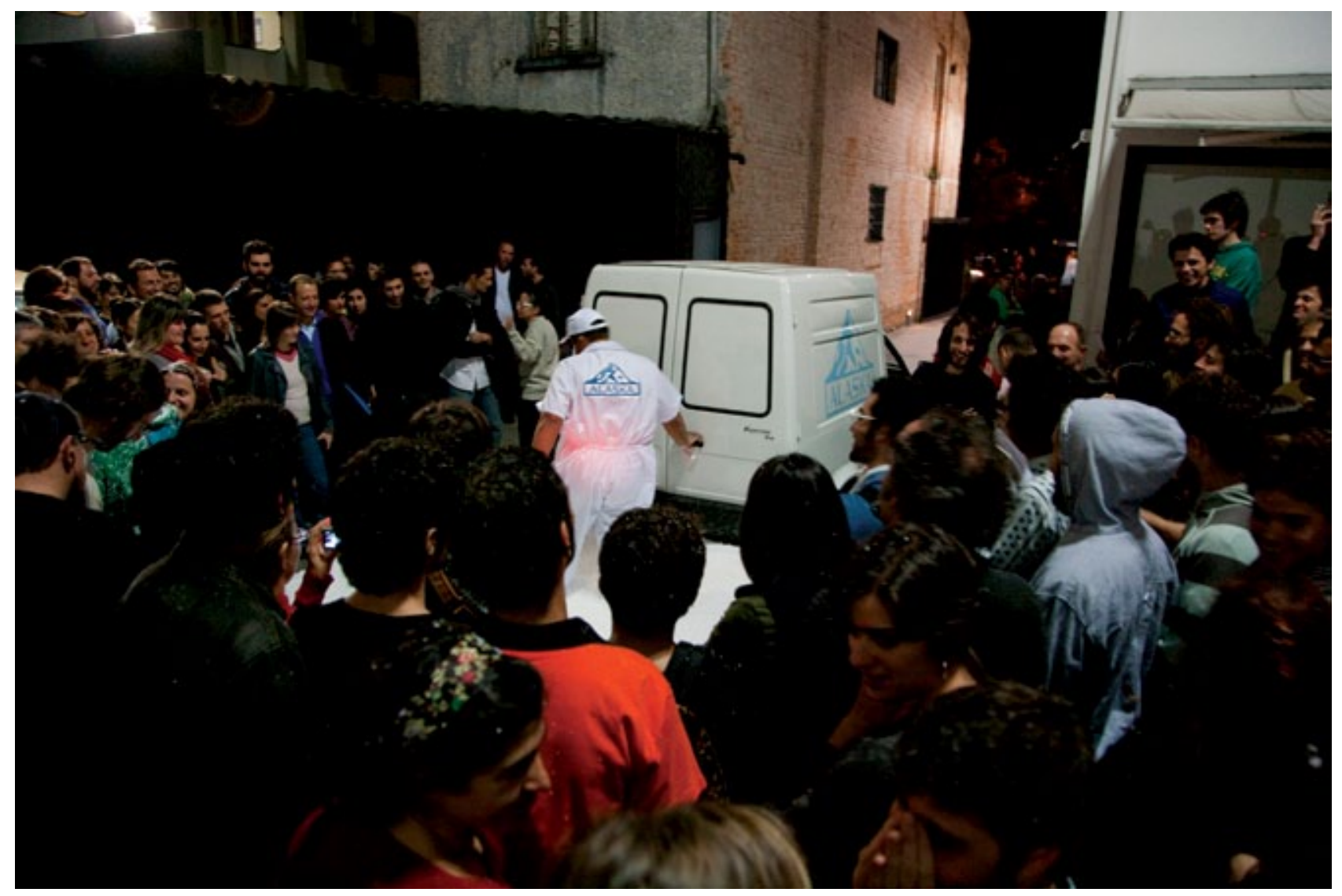




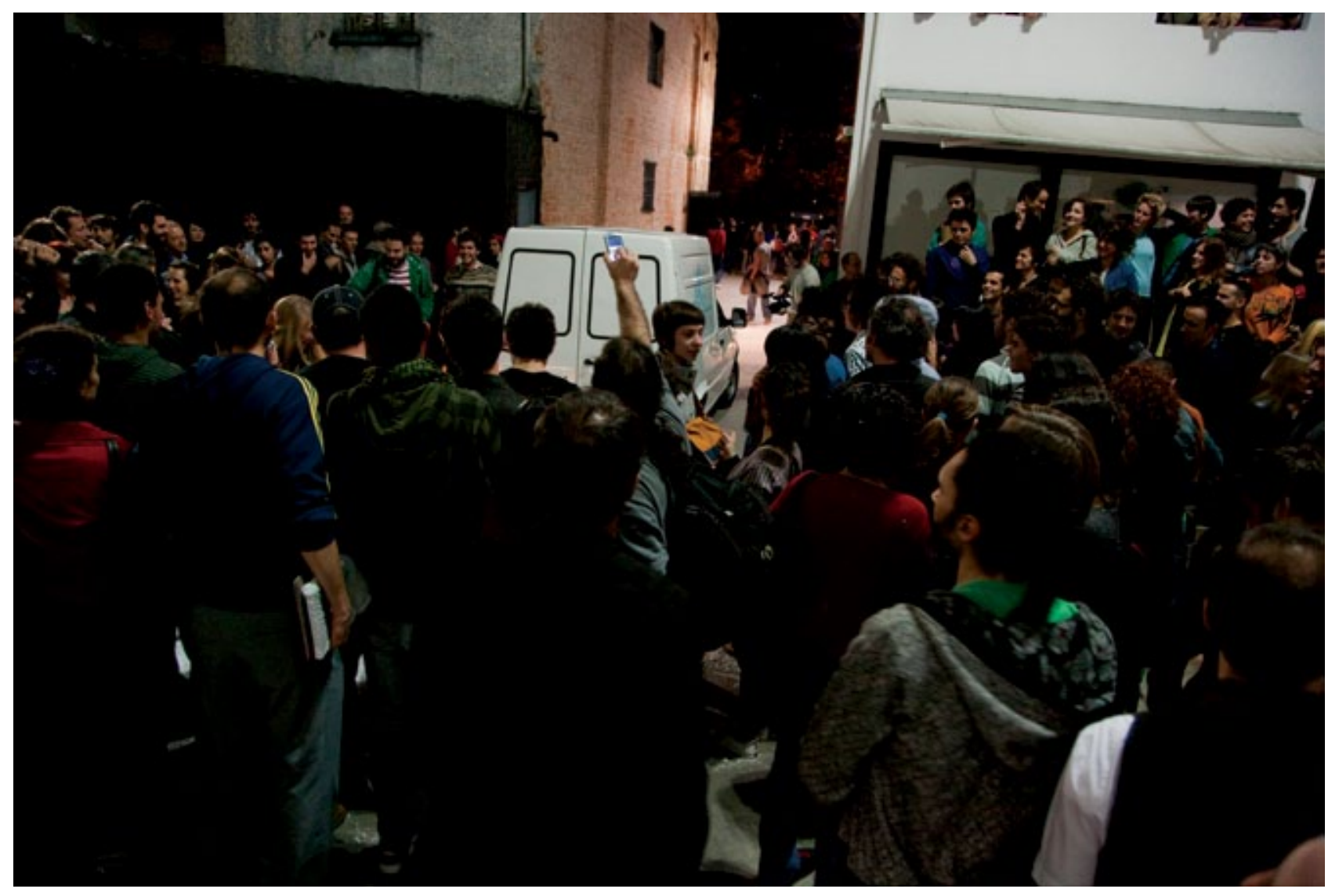




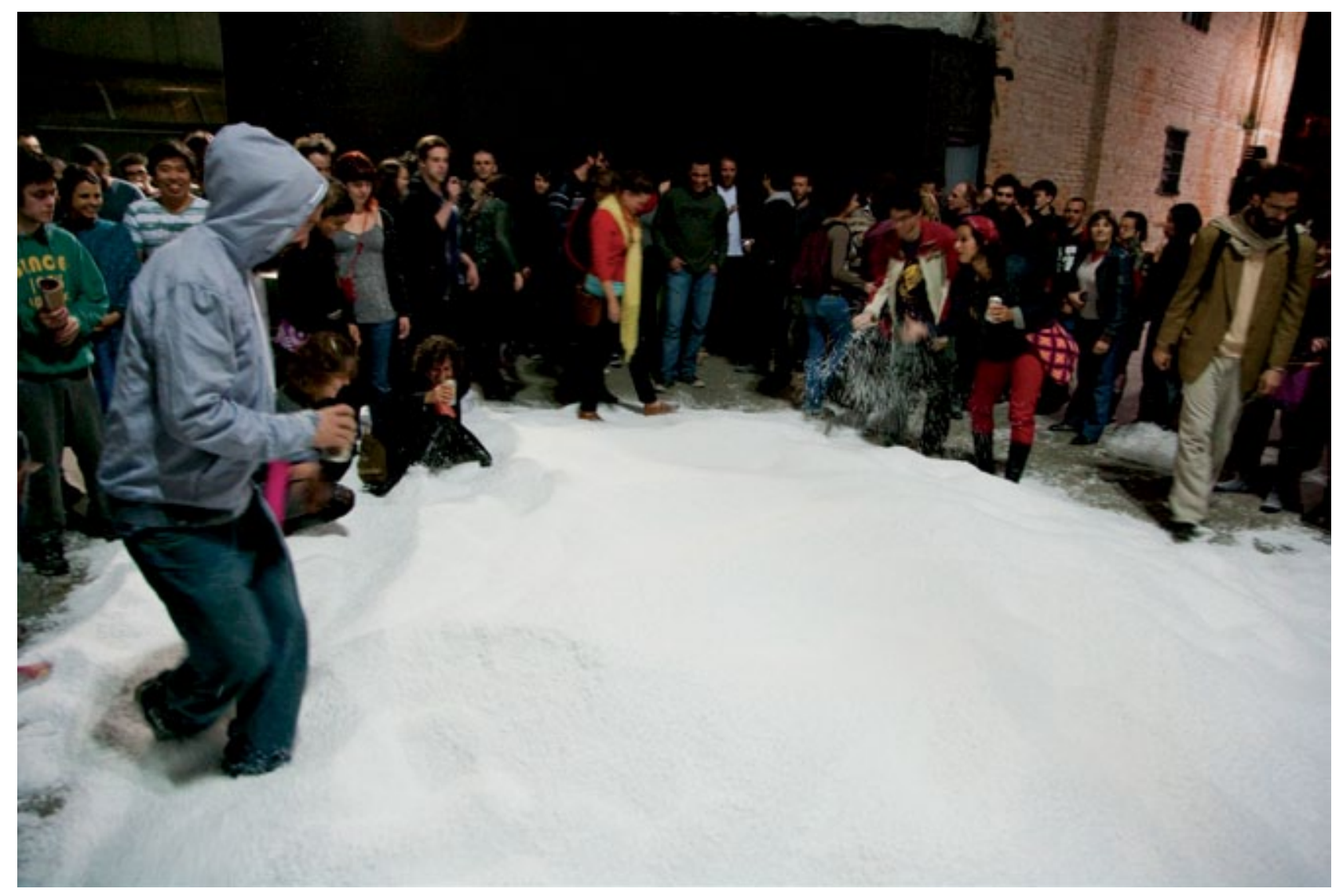




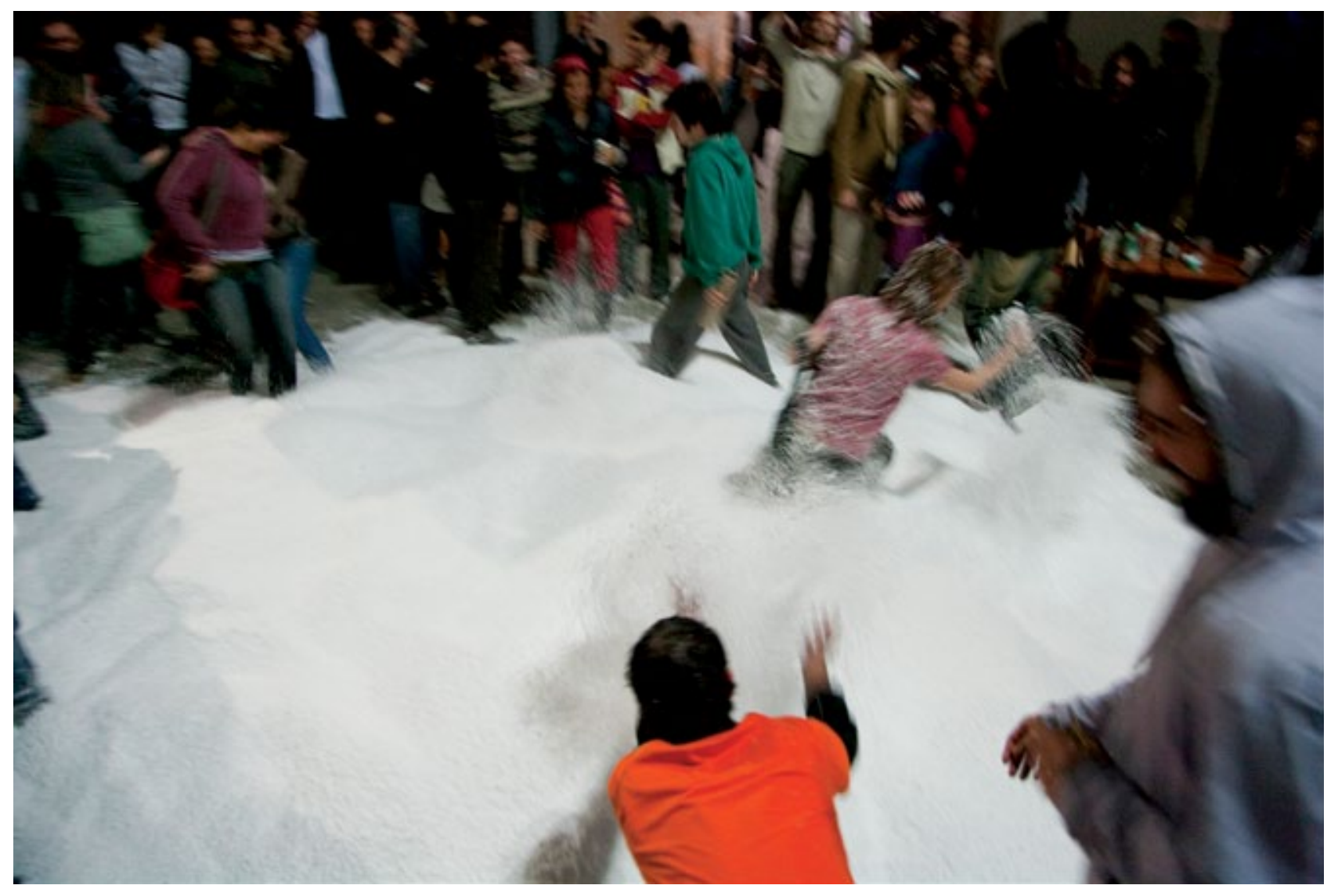




\section{Califórnia}

1. Escolha uma gráfica cujo nome esteja associado a uma paisagem de verão idealizada [Como exemplo, escolhemos a gráfica Califórnia, localizada no bairro da Barra Funda, em São Paulo];

2. Crie uma peça para ser reproduzida exclusivamente pela gráfica. $O$ impresso deve fazer alusão à paisagem original e, ao mesmo tempo, evidenciar o processo pelo qual passa o papel na hora da impressão [Na publicação Califórnia, concebeu-se um pequeno folder dobrável que trazia em sua superfície um suave degradê. Sobre a delicada mudança de tons, foi aplicada uma textura reticular característica da indústria gráfica, porém de forma ampliada];

3. Devem constar no verso do impresso apenas informações sobre ele próprio: o nome e endereço da gráfica, a fonte utilizada, a tiragem, o tipo de papel e sua gramatura;

4. Construa um display de acrílico e distribua gratuitamente o folheto em locais como centros culturais, museus e galerias de arte. Seguindo este passo-a-passo você poderá criar uma interessante obra gráfica site-specific. 


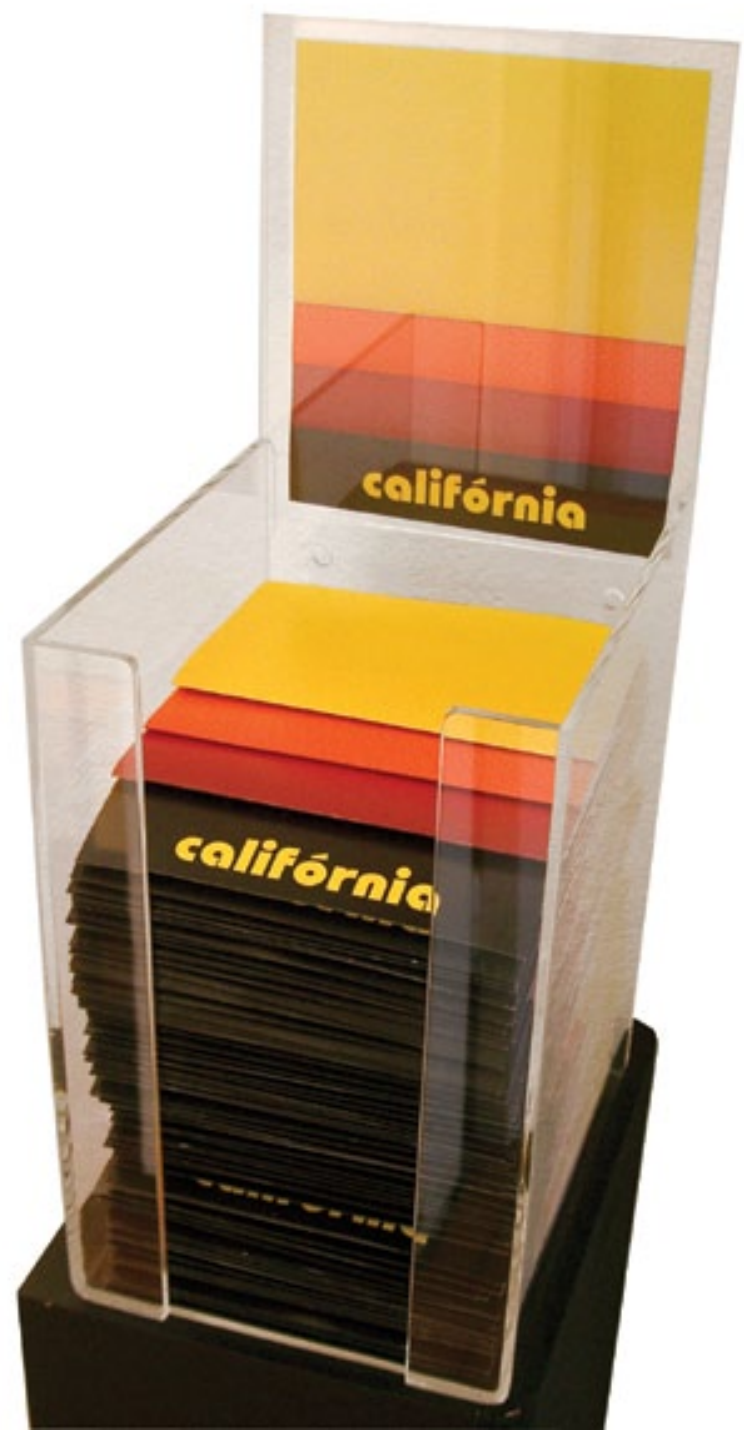



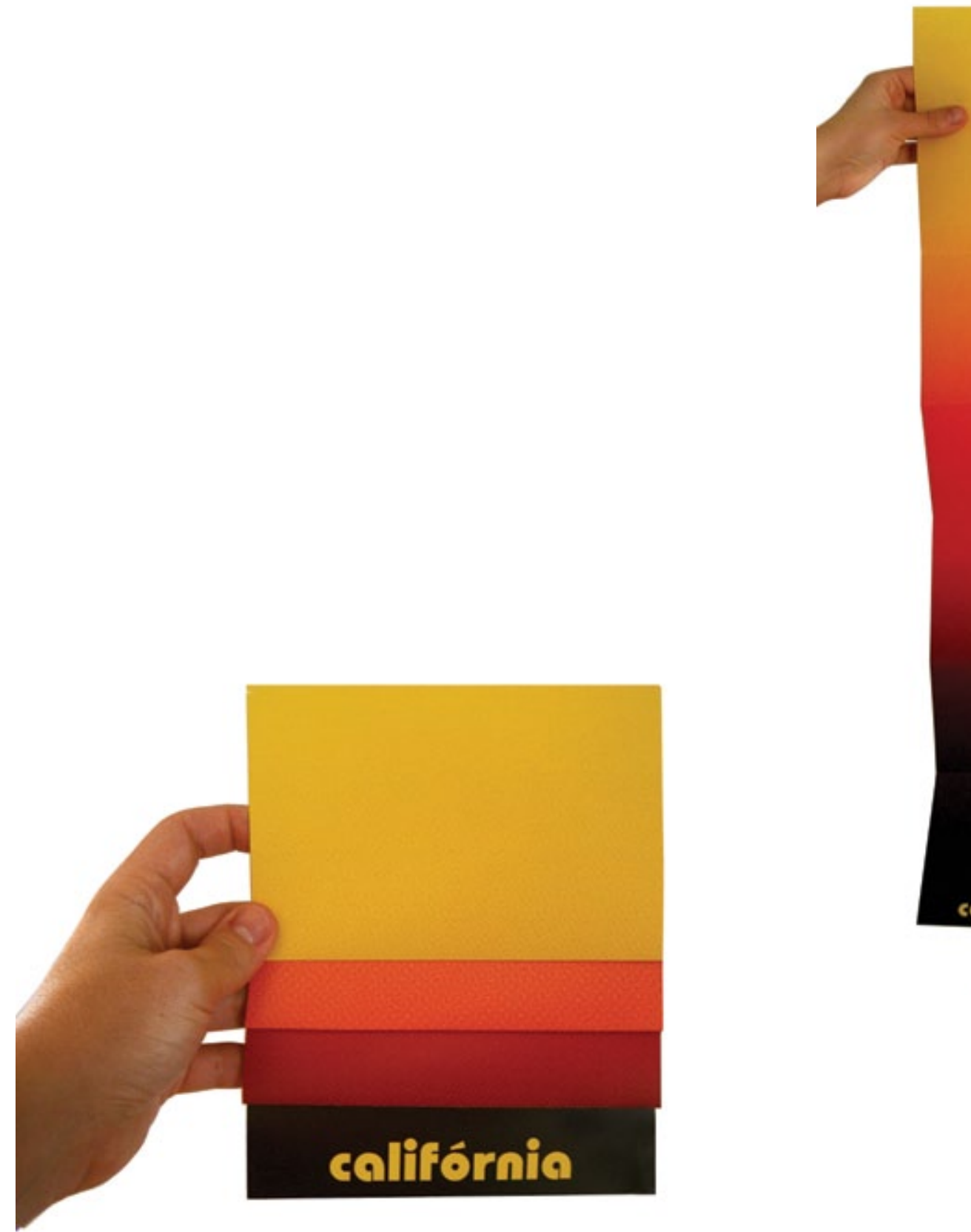

califórnio

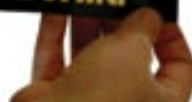




\section{Paradiso}

1. Escolha uma vitrine para ocupar [Mostramos a seguir a ocupação de uma vitrine expositiva pertencente a um museu, situada em uma estação de metrô em São Paulo];

2. Eleja uma palavra que faça alusão ao sentimento nostálgico experimentado pelo homem em relação à perda de uma suposta unidade primordial entre humanidade e natureza ${ }^{8}$. Ao escolher a palavra, não é necessário se preocupar excessivamente com a origem e o significado do termo, mas principalmente com a maneira pela qual a palavra é apropriada pelo cotidiano e com as imagens que evoca;

3. Escreva a palavra com letras vazadas em uma película adesiva preta;

4. Aplique a película sobre a vitrine, de modo que seu interior seja visível apenas através da palavra;

5. No interior da vitrine, faça um grande arranjo utilizando objetos que copiam habilmente elementos da natureza. Garanta que sua seleção proporcione uma sensação de conforto para o espectador $^{9}$;

6. Escolha uma cor para iluminar o arranjo produzido. Lembre-se: as cores são ricas em associações, imagens e significações que devem ser levadas em consideração;

7. Por último, acrescente uma ambientação sonora externa à vitrine [ $\mathrm{Na}$ estação de metrô, os sons escolhidos foram os de pássaros, cachoeira e vento]. O áudio deve ser um convite não somente à espreita através da palavra, mas um estímulo para que cada um acesse sua própria imagem mental de paraíso ${ }^{10}$.

\footnotetext{
8 ver verbete promenade (p. 64).
}

9 ver verbete conforto (p. 67).

10 ver verbetes paraíso (p.72) e Skinner no verbete fantasmagoria (p. 78). 


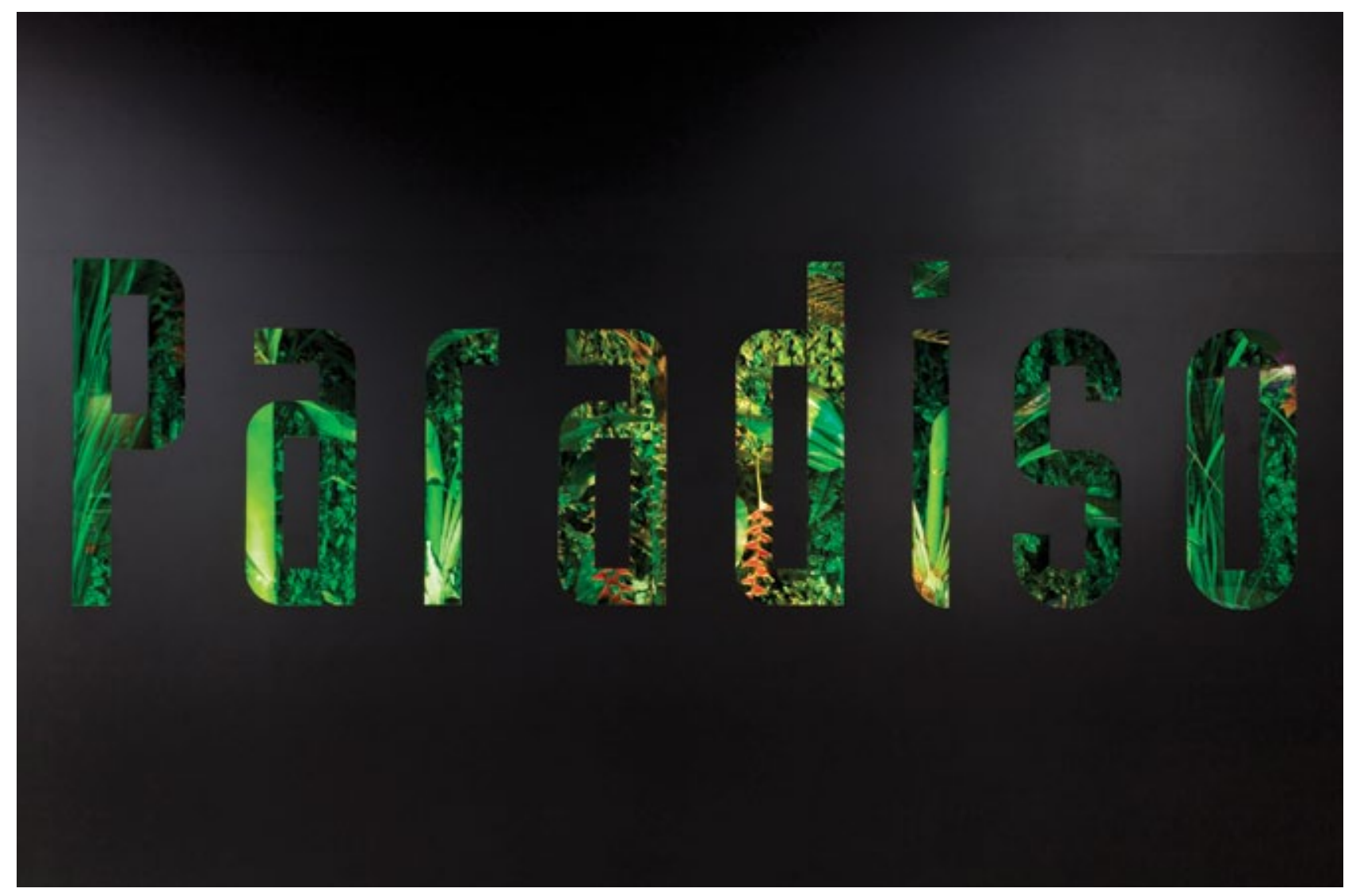




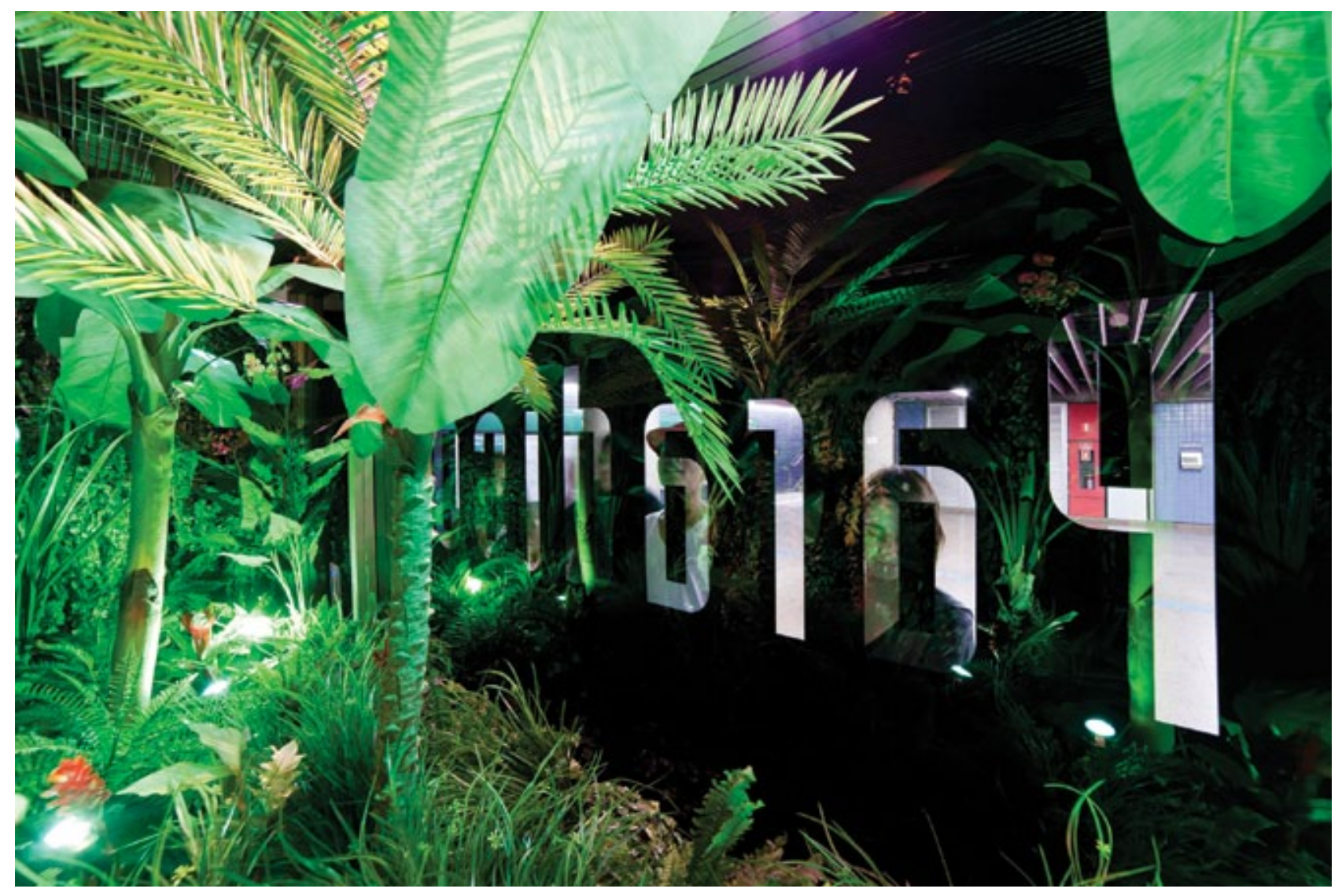




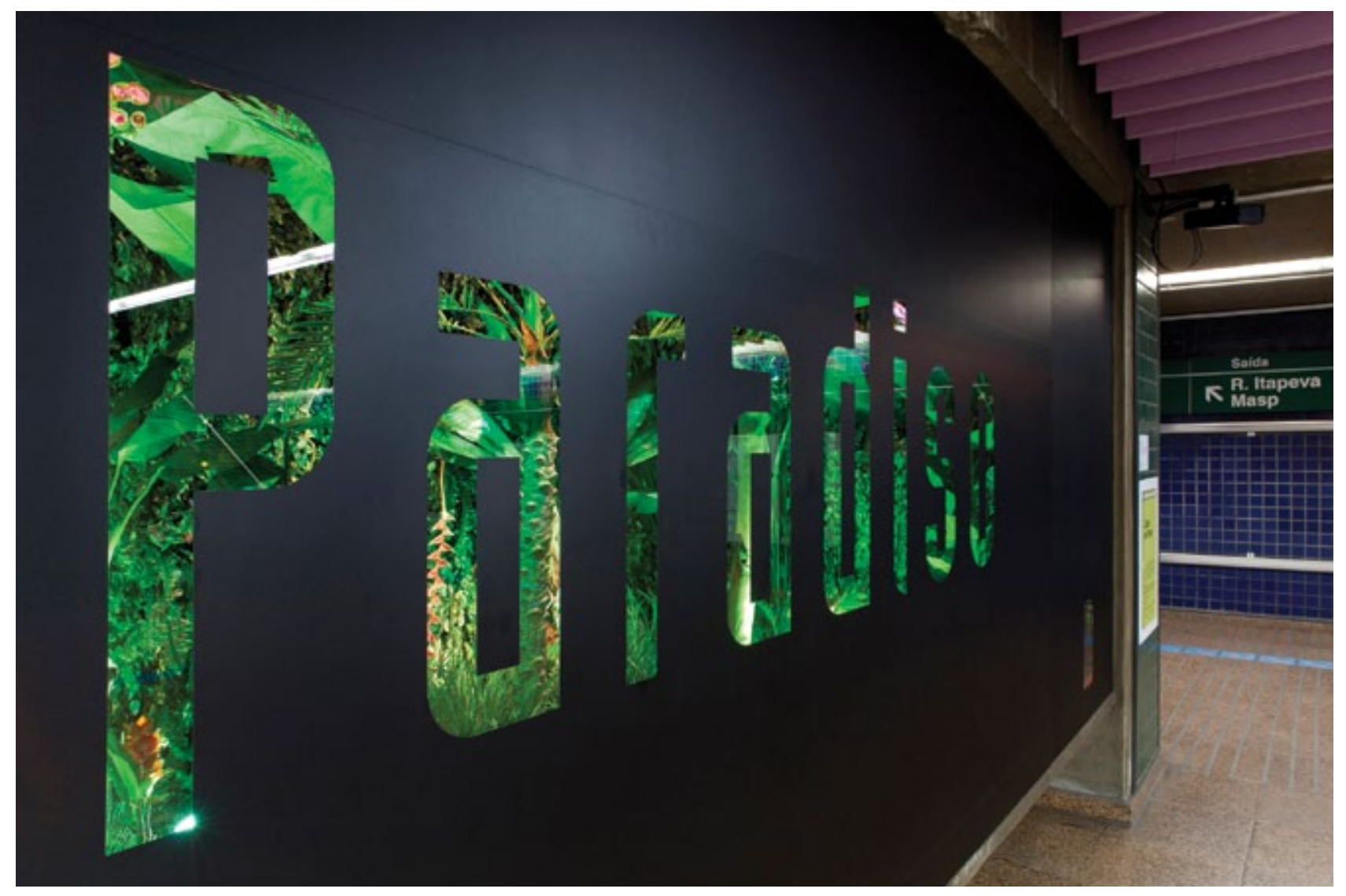




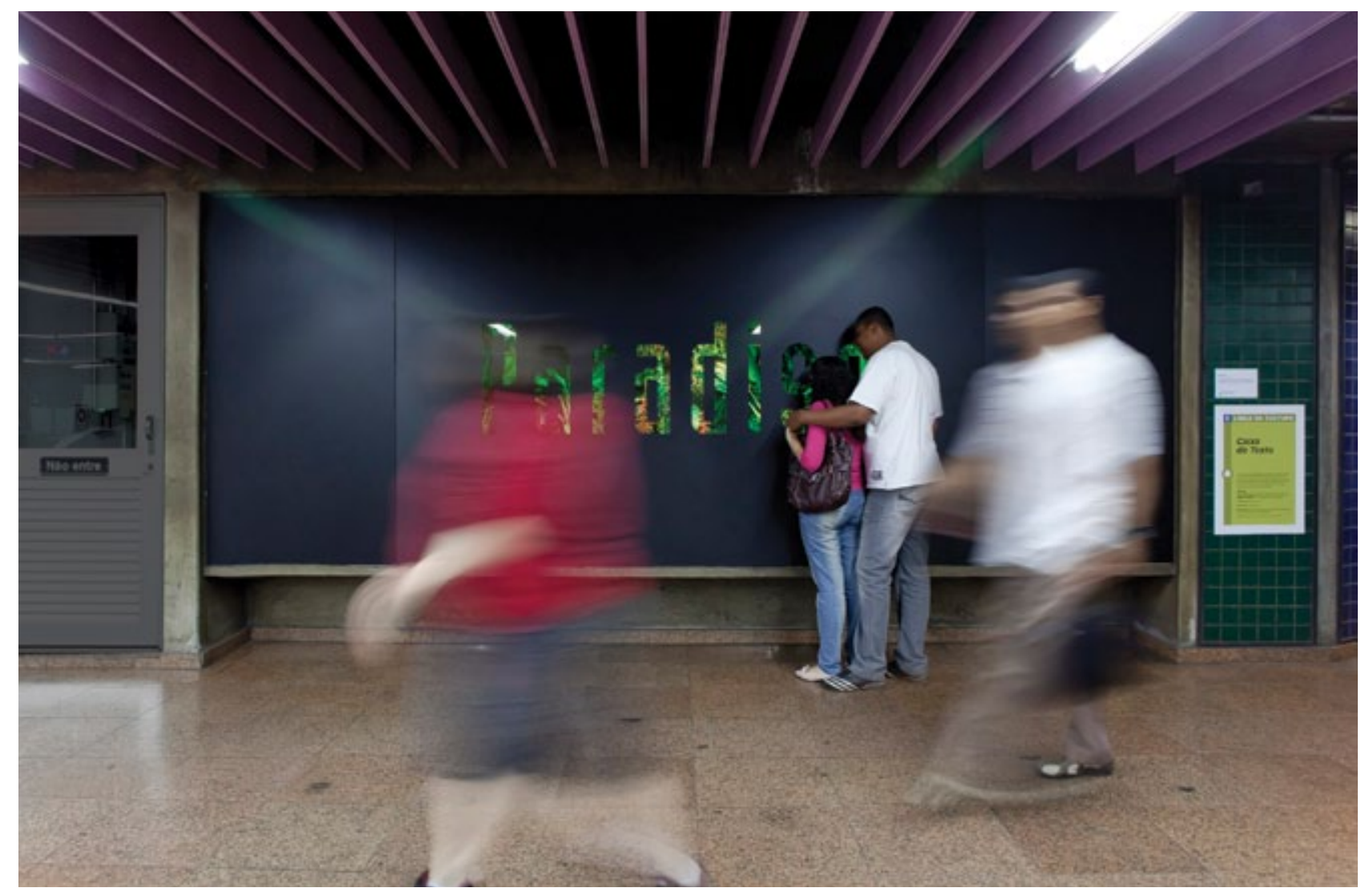




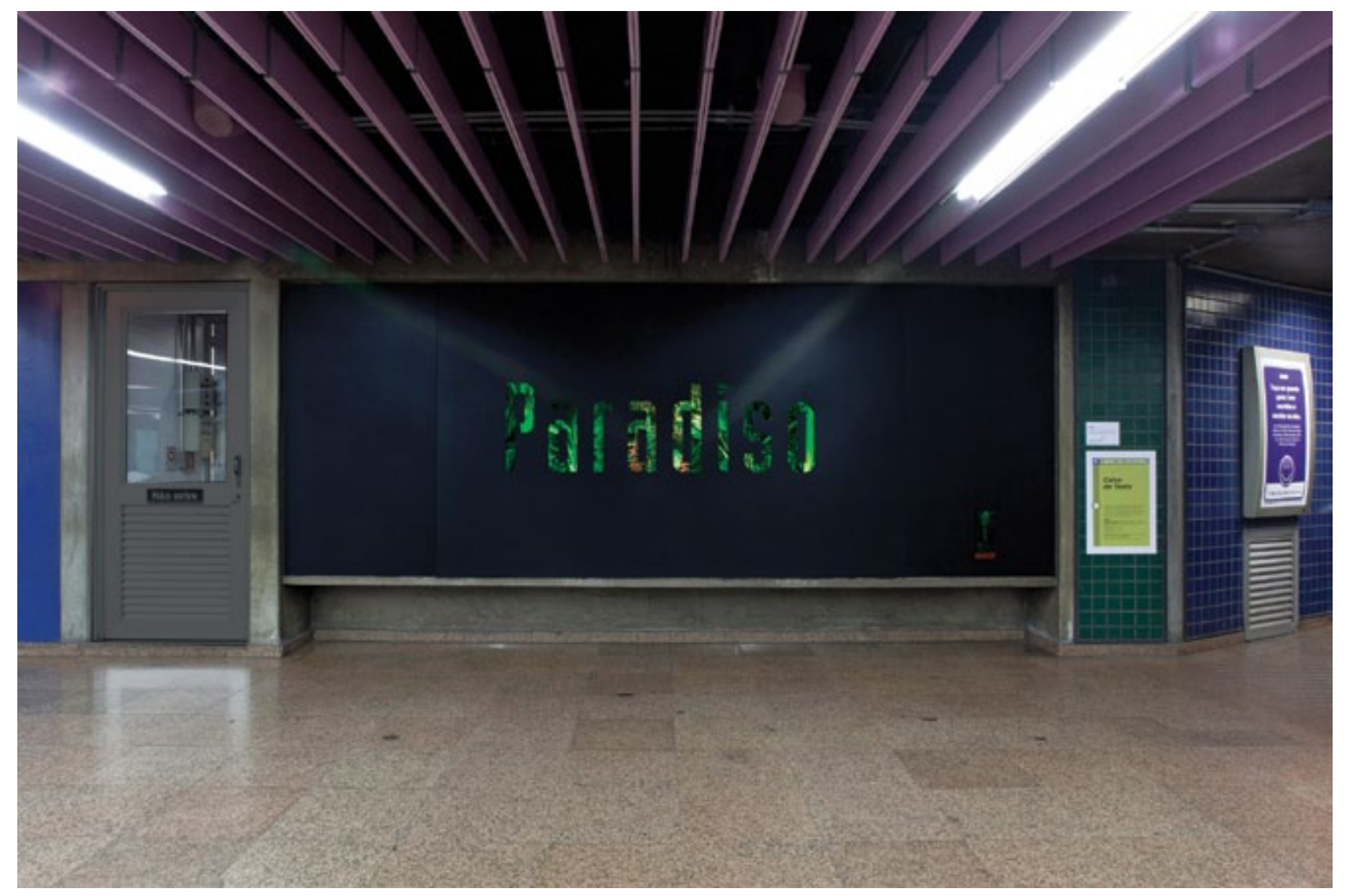




\section{Mirage}

1. Faça uma viagem;

2. Visite pontos turísticos;

3. Encontre nesses locais, ou a caminho deles, anteparos transparentes como janelas de edifícios, aviões, trens e ônibus;

4. Cole sobre os anteparos uma palavra cujo significado tenha relação com o ato de ver ${ }^{11}$;

5. Veja e depois fotografe a paisagem intermediada pela palavra;

6. Deixe a palavra no anteparo para que seja vista pelos próximos viajantes.

Observação: Lembre-se, a paisagem não está lá. Está entre ${ }^{12}$.

11 ver verbetes souvenir (p.74) e miragem (p.75).

12 ver verbete janela (p.66). 


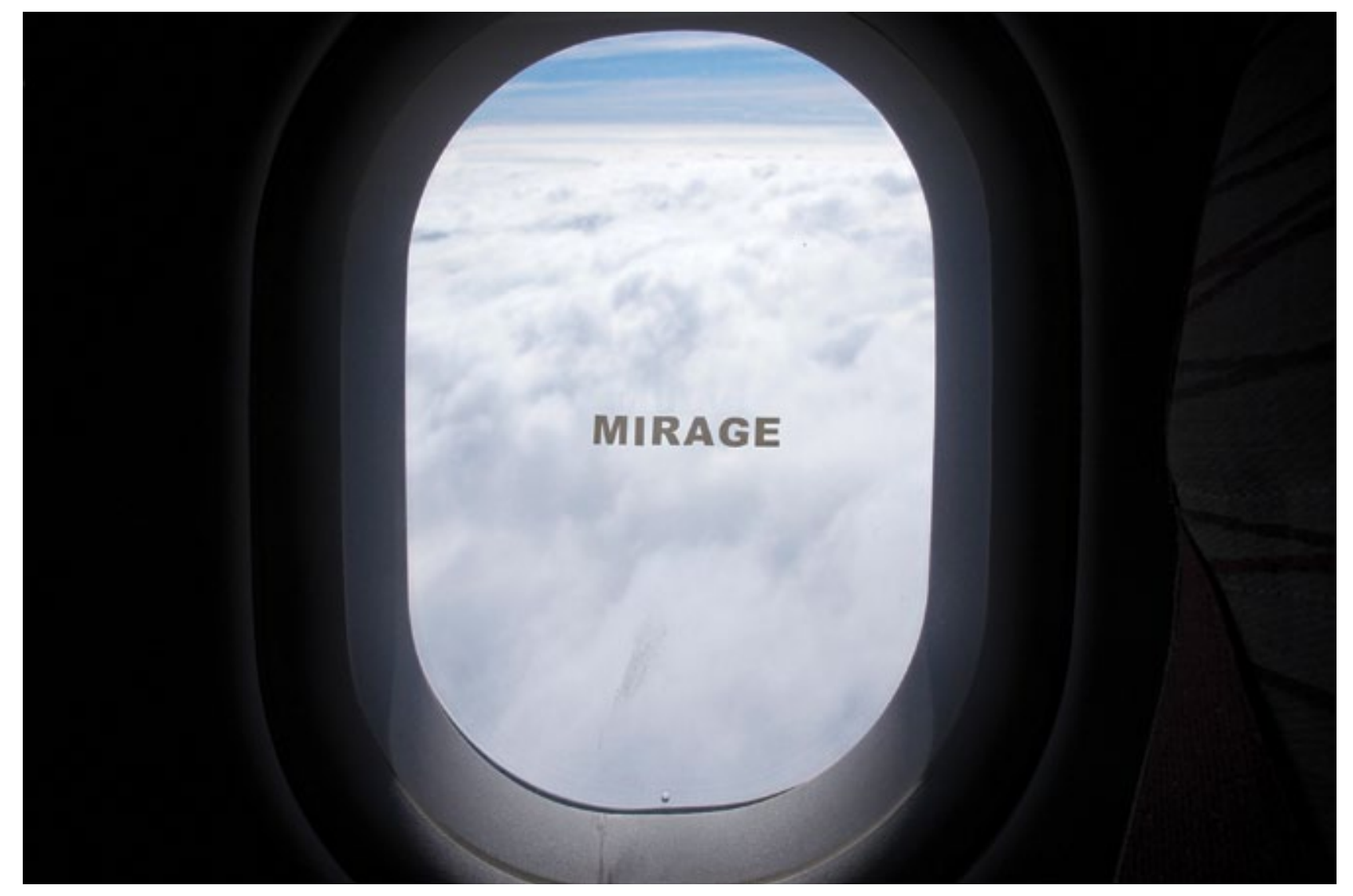




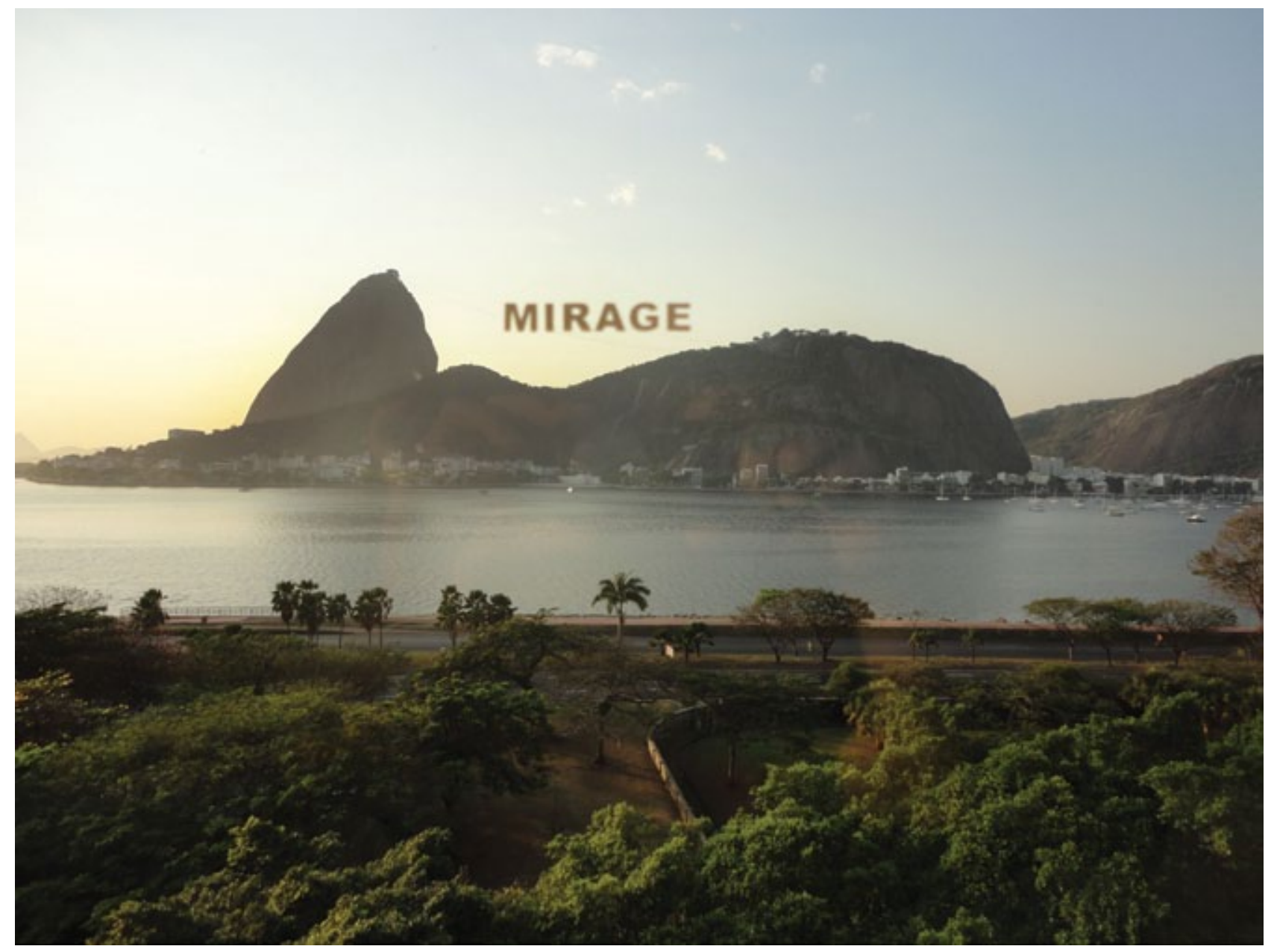




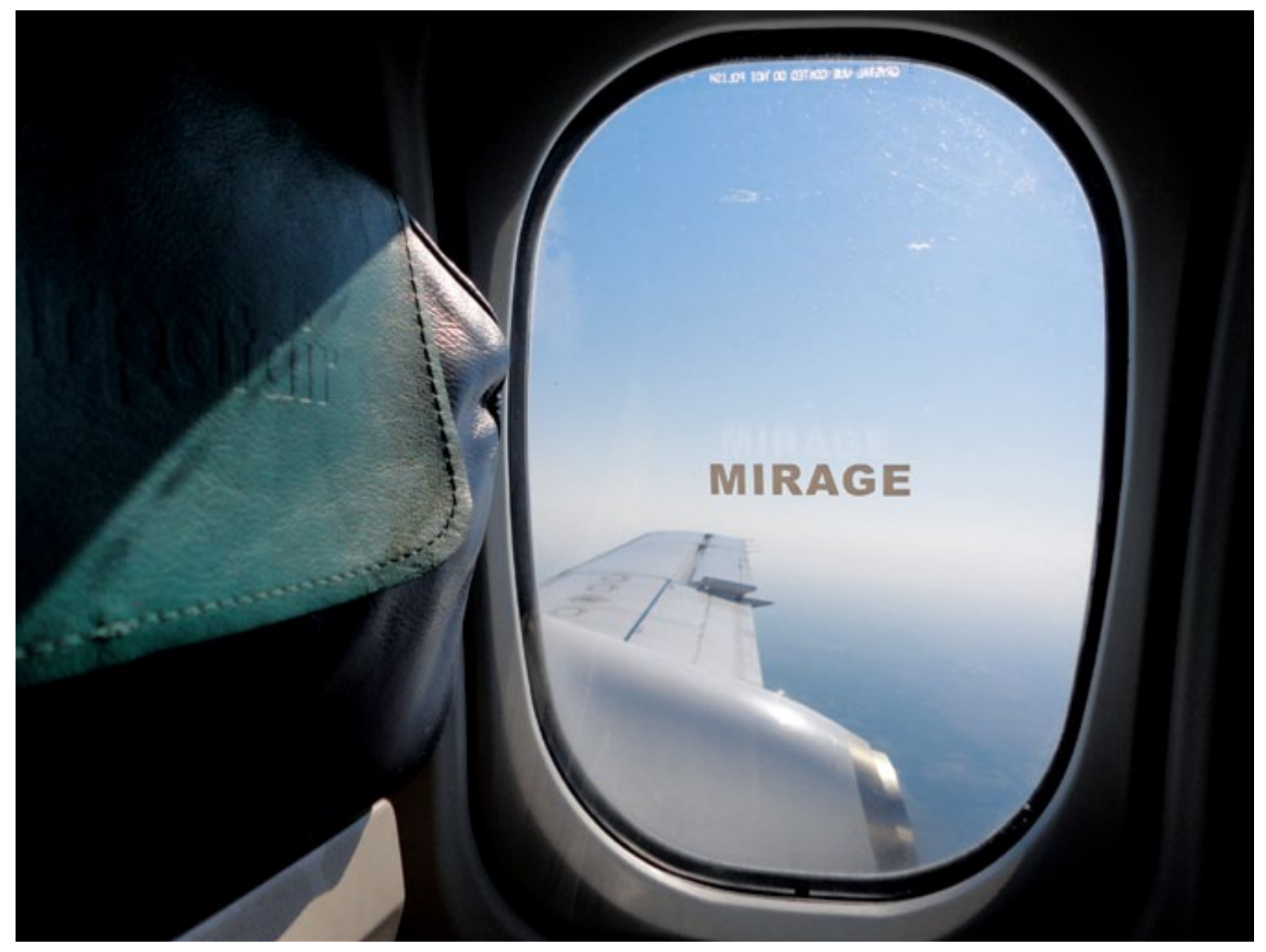




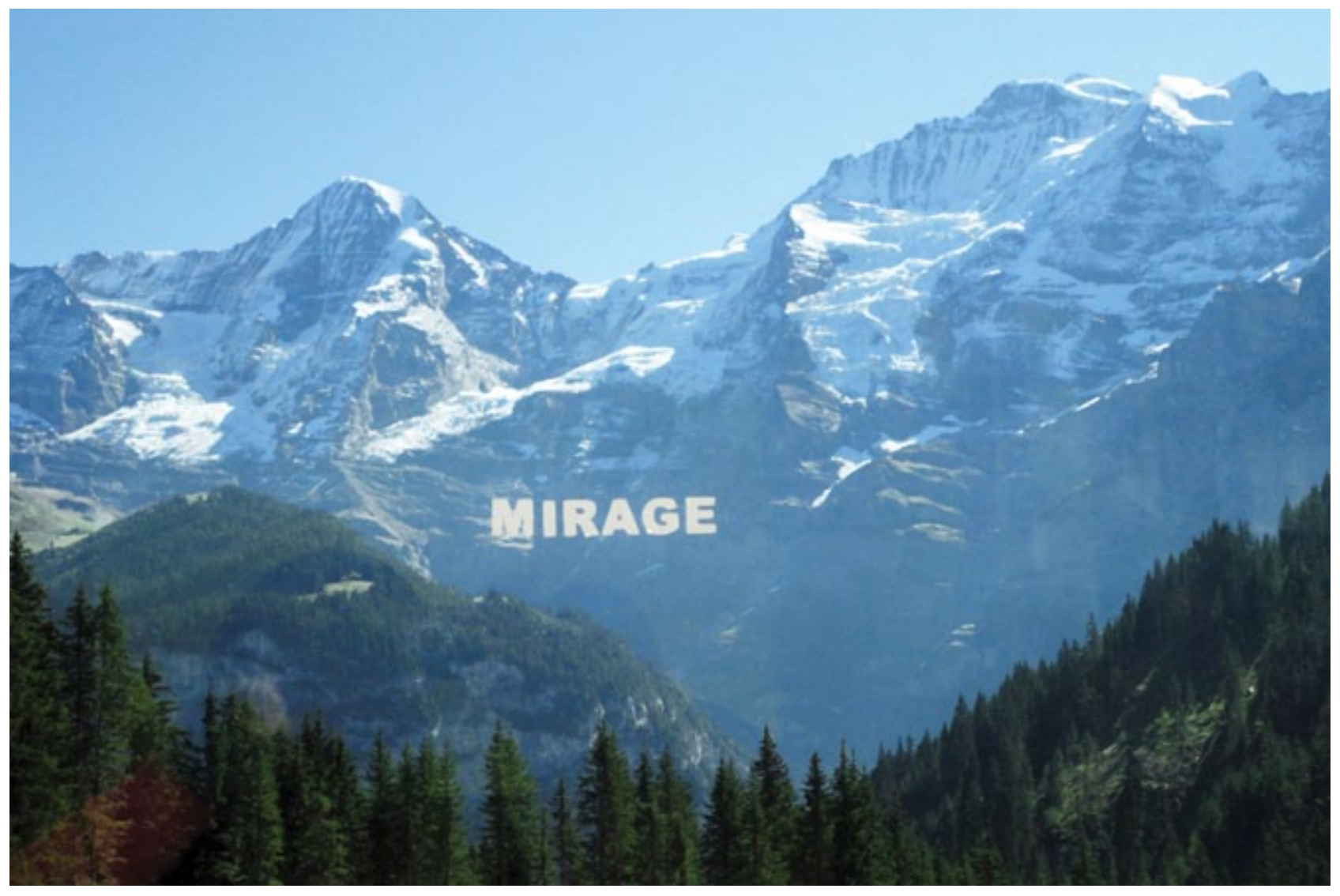




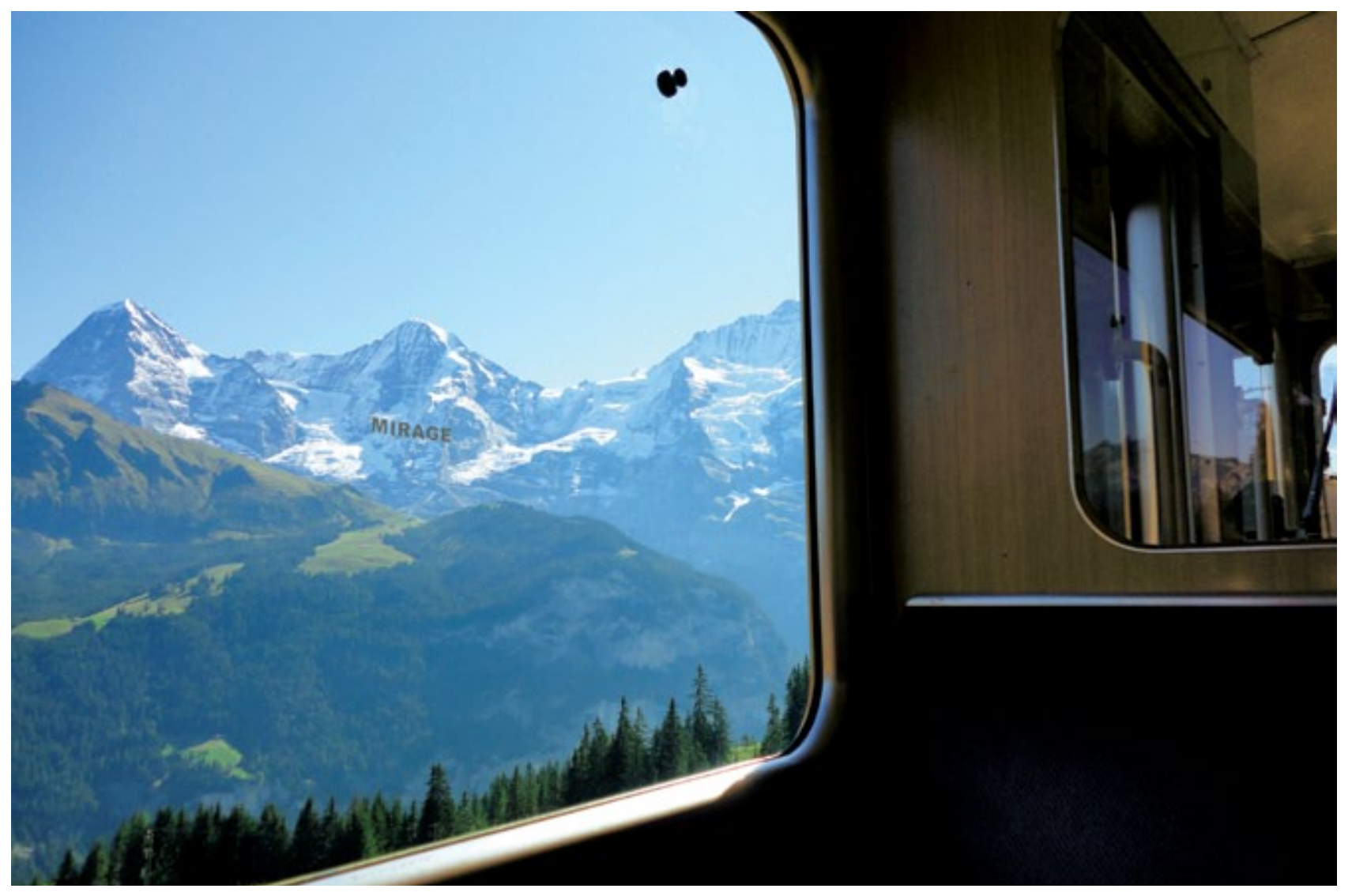




\section{Como pintar picos nevados}

Algumas dicas antes de começar... Antes de apanhar sua tela e seus pincéis, aceite alguns conselhos.

- Em se tratando de uma obra de arte contemporânea, é importante primeiro estabelecer regras, ou seja, um plano conceitual para a obra.

No processo que apresentamos como exemplo, estipulamos duas regras: a primeira estabelecia que não seria permitido ter lições gerais de pintura. Somente se deveria aprender a pintar picos nevados. A segunda regra designava que a instrução ocorresse exclusivamente por meio de manuais de pintura e vídeos tutoriais.

- É importante pensar também no espaço que irá receber a exposição. A disposição da sala expositiva é adequada?

Em Como Pintar Picos Nevados, optamos por modificar o espaço para que adquirisse uma conformação semelhante a de um panorama. Note que, ao contrário do que ocorria no século XIX, quando os panoramas eram instalados em rotundas ou salas circulares, aqui, a ortogonalidade da sala (seus cantos) foi mantida. Preservar alguns sinais de inadequação é importante para que o espectador não se sinta enganado: isto serve para lembrá-lo de que ele não está realmente imerso na paisagem retratada ${ }^{13}$.

- Outro aspecto que deve ser determinado antes da fase de produção das pinturas é a disposição definitiva das telas na sala de exposição - deve-se dispô-las lado a lado, alinhadas por suas bases, a despeito de seus formatos e tamanhos.

Essa disposição é recomendada para que se possa estabelecer uma linha do horizonte contínua sobre a qual, posteriormente, se vai estruturar a cadeia de montanhas. É também indicada porque permite aferir o desenvolvimento cronológico do aprendizado do artista, como uma espécie de linha do tempo.

- Não desanime se, após ter realizado um determinado número de pinturas, notar que a evolução do aprendizado parece estagnada. Ao contrário do que pode aparentar, isto apenas significa que você atingiu um bom padrão de pintura e que não há mais o que progredir. Você poderá então dedicar-se somente à repetição dos motivos.

Passemos finalmente ao aprendizado específico do método Como Pintar Picos Nevados ${ }^{\circledR}$.

13 ver verbetes panorama (p.68) e trompe-I`oeil (p.67). 
As instruções e imagens a seguir foram retiradas do vídeo Como Pintar Picos Nevados ${ }^{\circledR}$, que se encontra disponível em DVD ao final deste volume. Leia atentamente e mãos à obra!

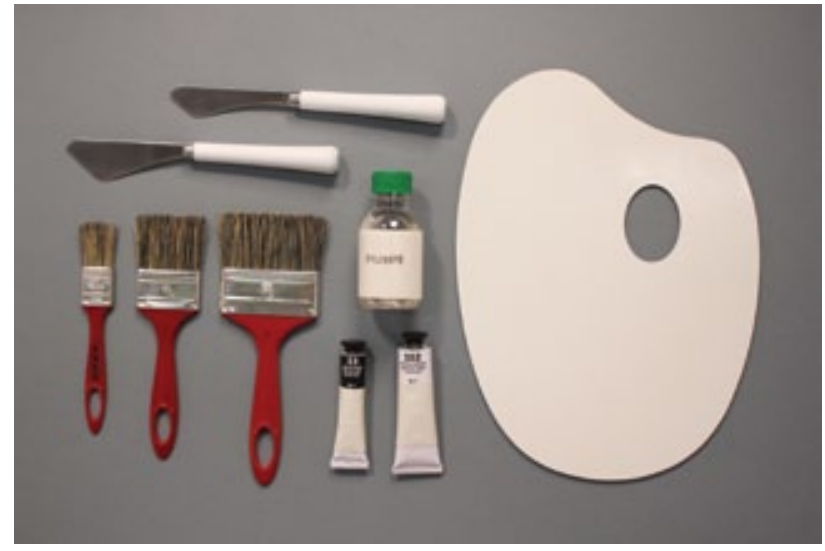

Além da tela, serão necessários os seguintes materiais: tinta a óleo nas cores Branco de Titânio e Gris de Payne; diluente inodoro; pincéis de cerdas duras de tamanhos variados; espátulas para pintura com pontas trapezoidais.

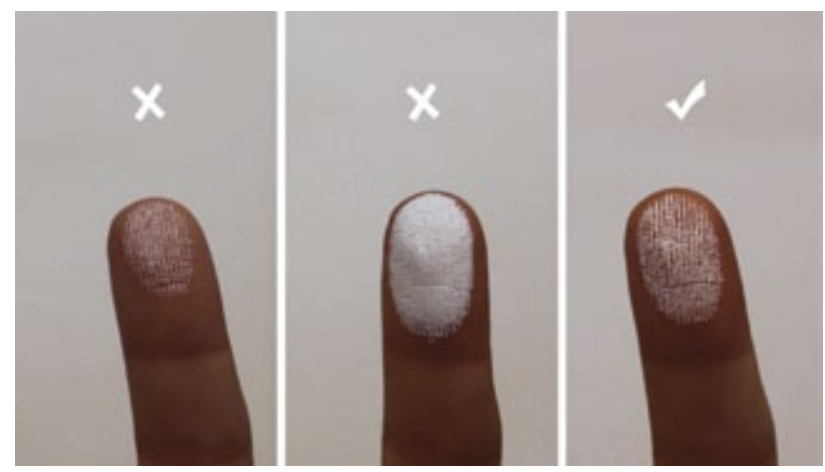

Para verificar se o recobrimento de tinta branca está correto, toque levemente a tela com a ponta do dedo. Se houver falta de tinta, a impressão digital aparecerá falha. Se houver excesso, as linhas da impressão digital ficarão encobertas.A aplicação estará correta quando a impressão digital estiver visível de modo claro e contínuo.

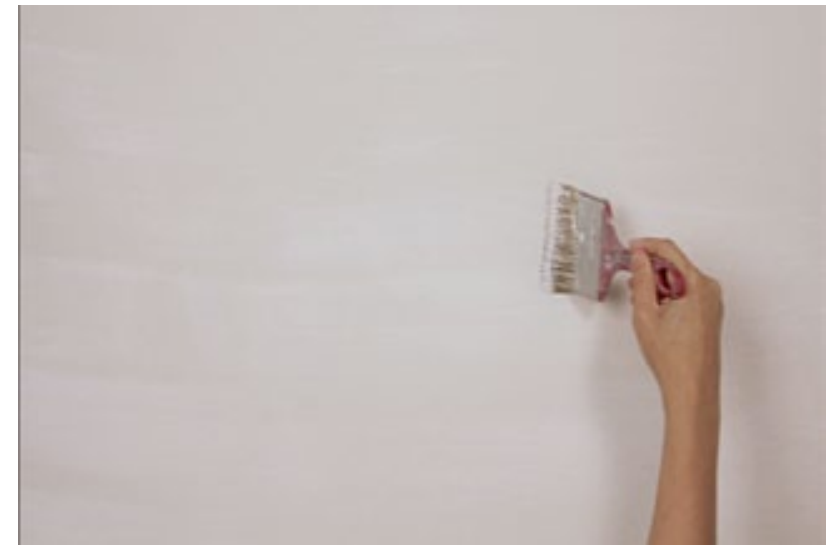

Para o correto desenvolvimento da técnica wet-on-wet é fundamental que seja aplicada uma fina camada de tinta branca sobre a tela antes de iniciar a pintura. Toda a pintura deve ser realizada com esta camada de tinta ainda úmida.Aplique a tinta com pinceladas longas e lentas, espalhando-a por igual sobre a tela.

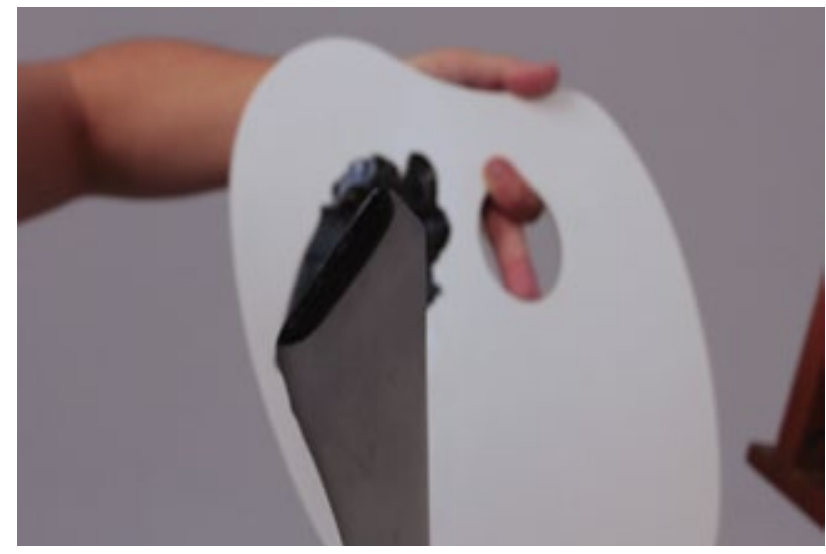

Use a espátula para espalhar uma fina camada de tinta Gris de Payne sobre a paleta. Em seguida, cruze a lâmina sobre a tinta na diagonal. Isto fará com que a borda da espátula concentre uma pequena faixa de tinta em quantidade uniforme. 


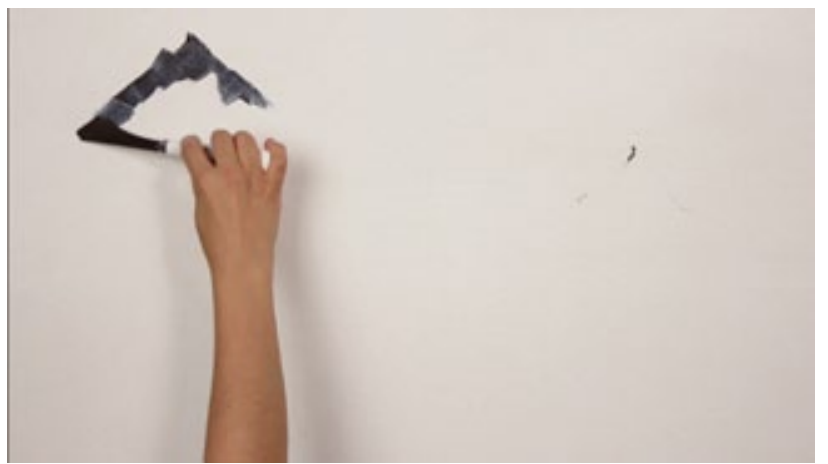

Comece a cadeia a partir do perfil das montanhas. Pressione a espátula com firmeza sobre a tela, desenhando contornos angulosos e recortados. Note como o formato de trapézio da ponta da espátula auxilia no desenho dos ângulos acentuados dos picos.

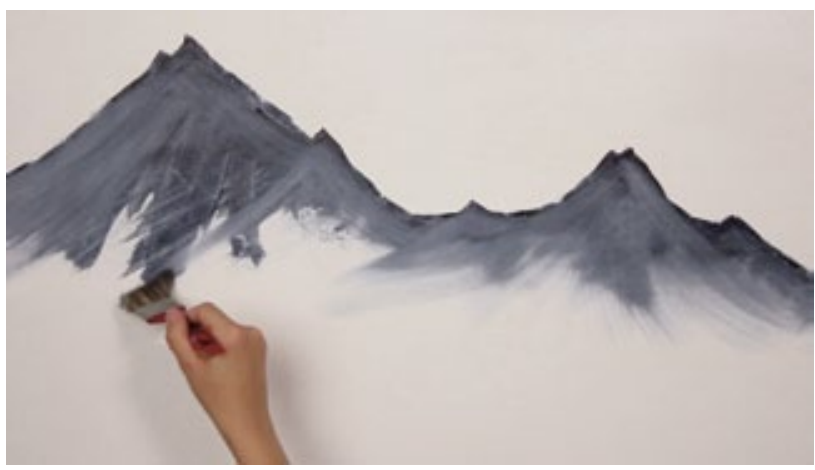

Com o pincel seco e limpo, comece a desenhar o volume das montanhas. Puxe o pincel sempre na diagonal, em movimentos que se iniciam no topo e terminam na base. Espalhe a tinta sempre de cima para baixo, nunca no sentido inverso.

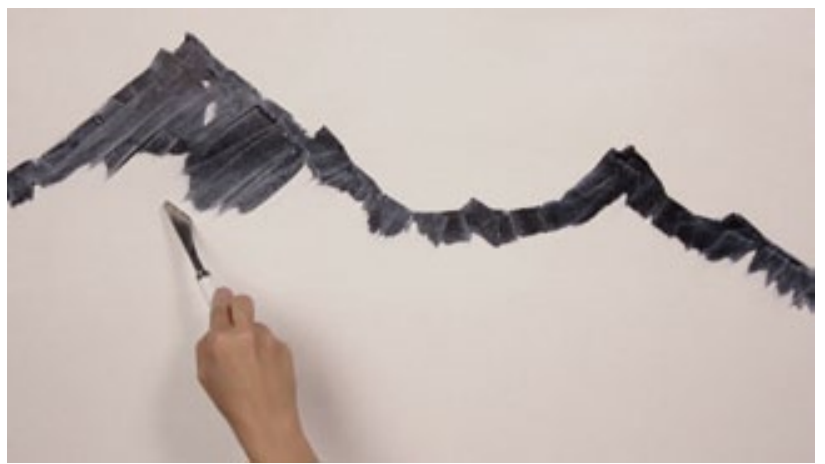

Espalhe a tinta pressionando a espátula firmemente sobre a tela e puxando-a energicamente para baixo. Se necessário, preencha os contornos com um pouco mais de tinta. Preocupe-se apenas em traçar o contorno superior das montanhas.

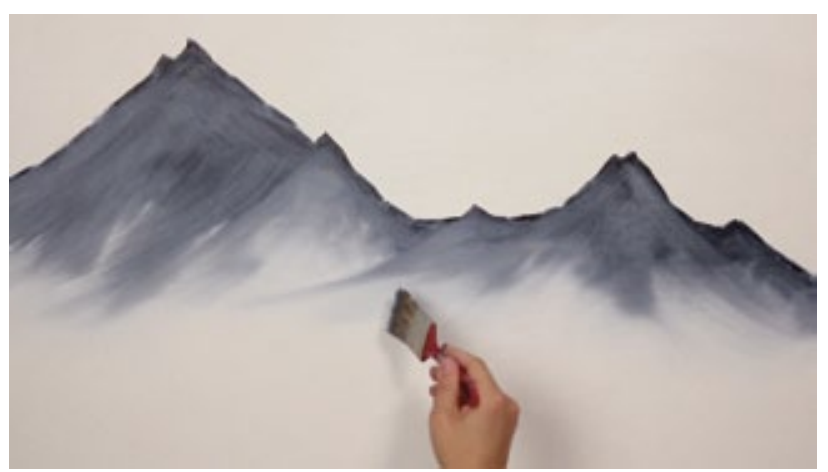

Suavize a base da montanha com leves pinceladas em forma de "x". 


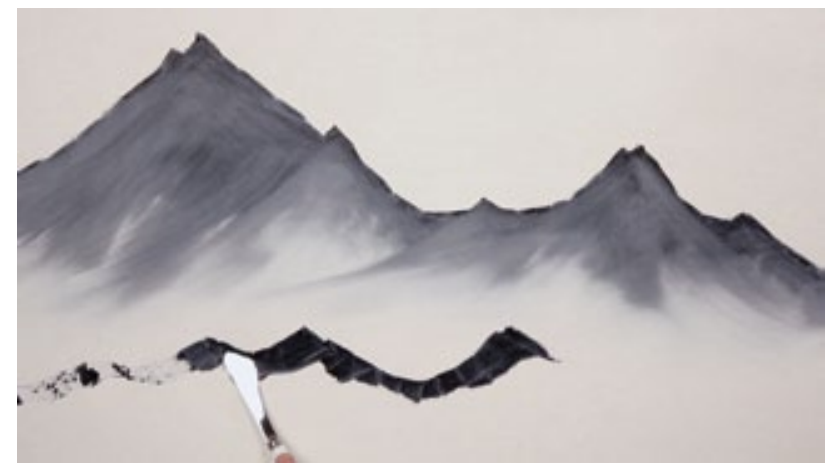

Você pode iniciar uma nova cadeia de montanhas repetindo os mesmos procedimentos.

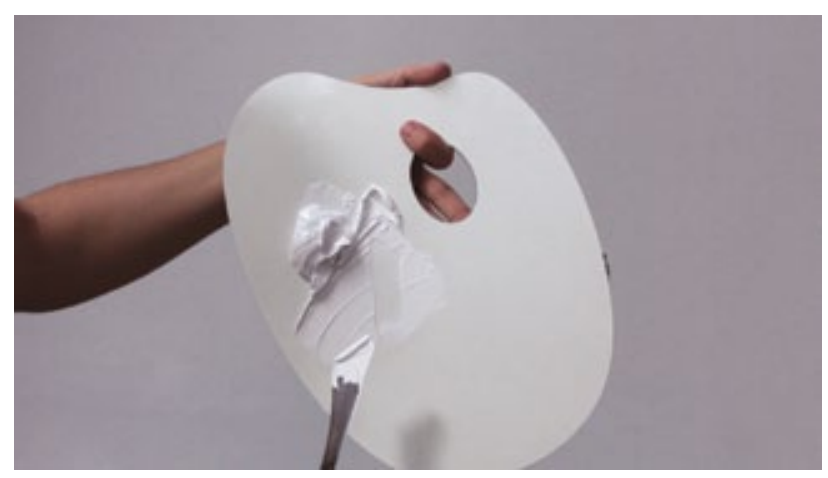

Carregue a espátula com o Branco de Titânio. Lembrese de que a tinta deve formar uma linha regular somente na borda da espátula.

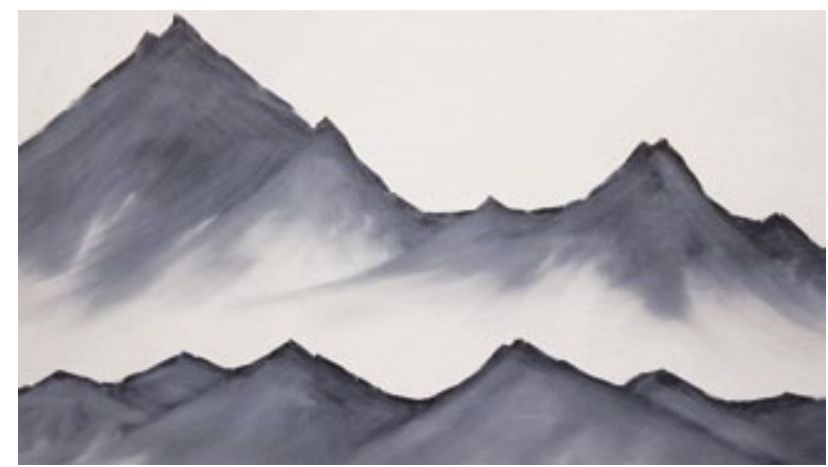

Lembre-se: com a espátula, trace o pefil das montanhas e espalhe a tinta de cima para baixo. Desenhe o volume com o pincel limpo e seco. Finalize suavizando a base com pinceladas em " $x$ ".

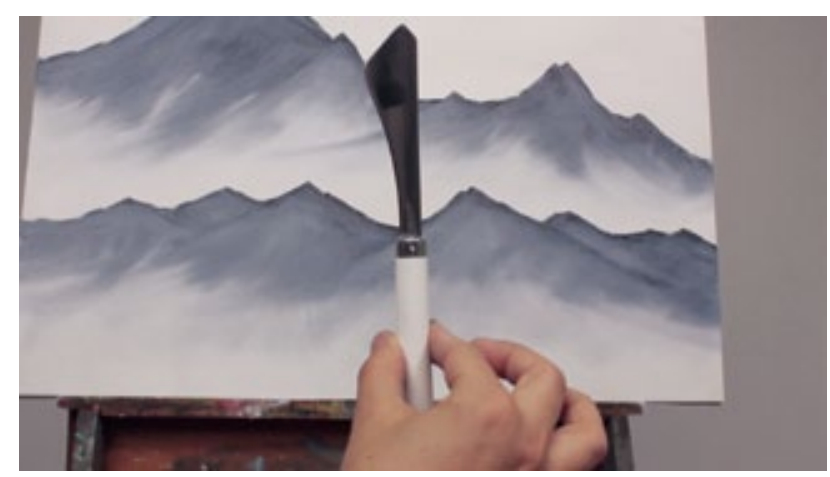

Segure a espátula com delicadeza entre o polegar e $o$ indicador. 


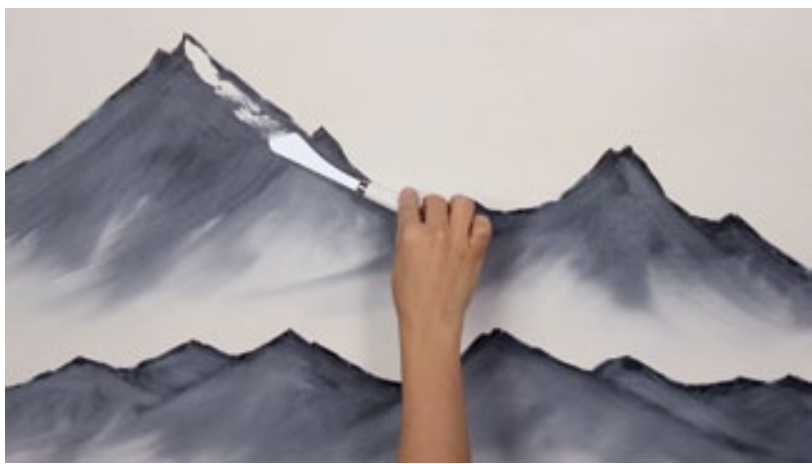

Aplique a tinta do lado direito das montanhas, de cima para baixo, em diagonal, encostando a espátula muito suavemente sobre a tela

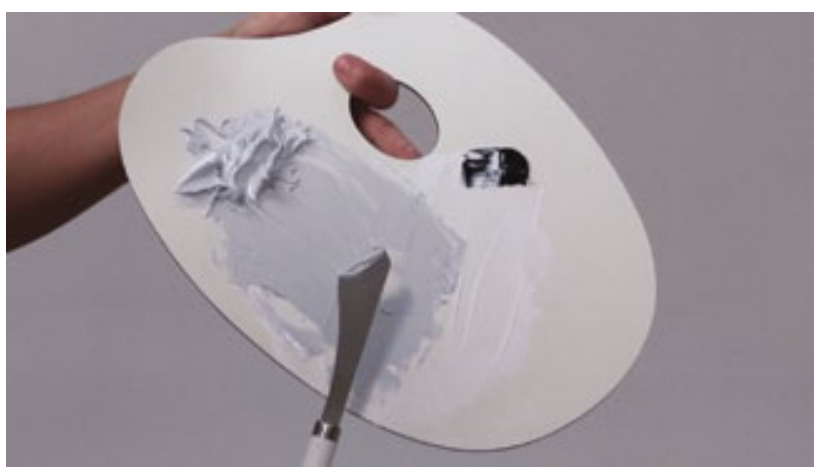

Carregue a espátula com uma mistura de Branco de Titânio e um pouco de Gris de Payne.

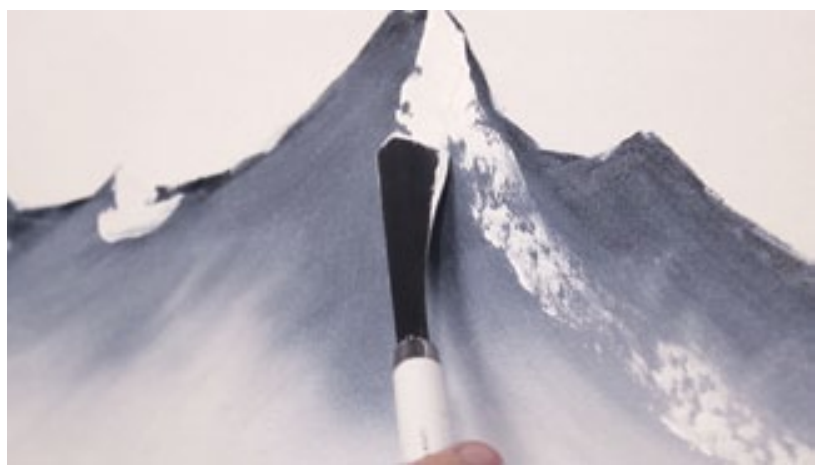

Note como, ao realizar esse movimento,produz-se certa irregularidade na cobertura branca. Esse efeito é essencial para que a pintura adquira o aspecto correto.

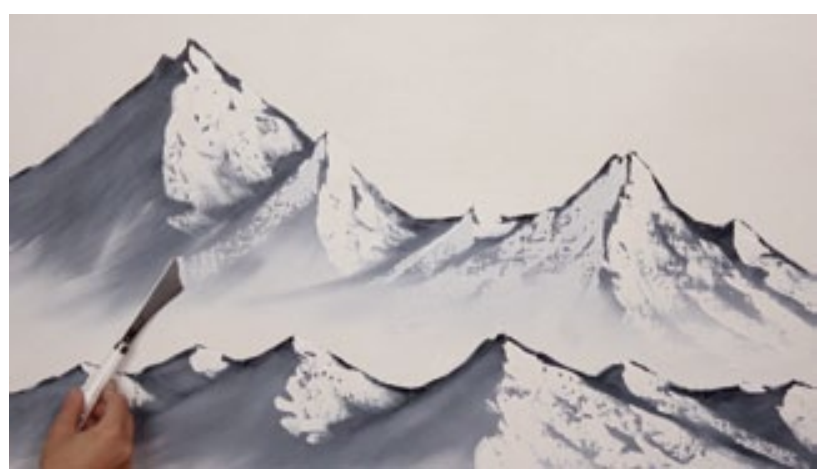

Aplique a tinta no lado esquerdo das montanhas, reproduzindo o mesmo procedimento do estágio anterior: de cima para baixo, em diagonal, encostando a espátula suavemente sobre a tela. 


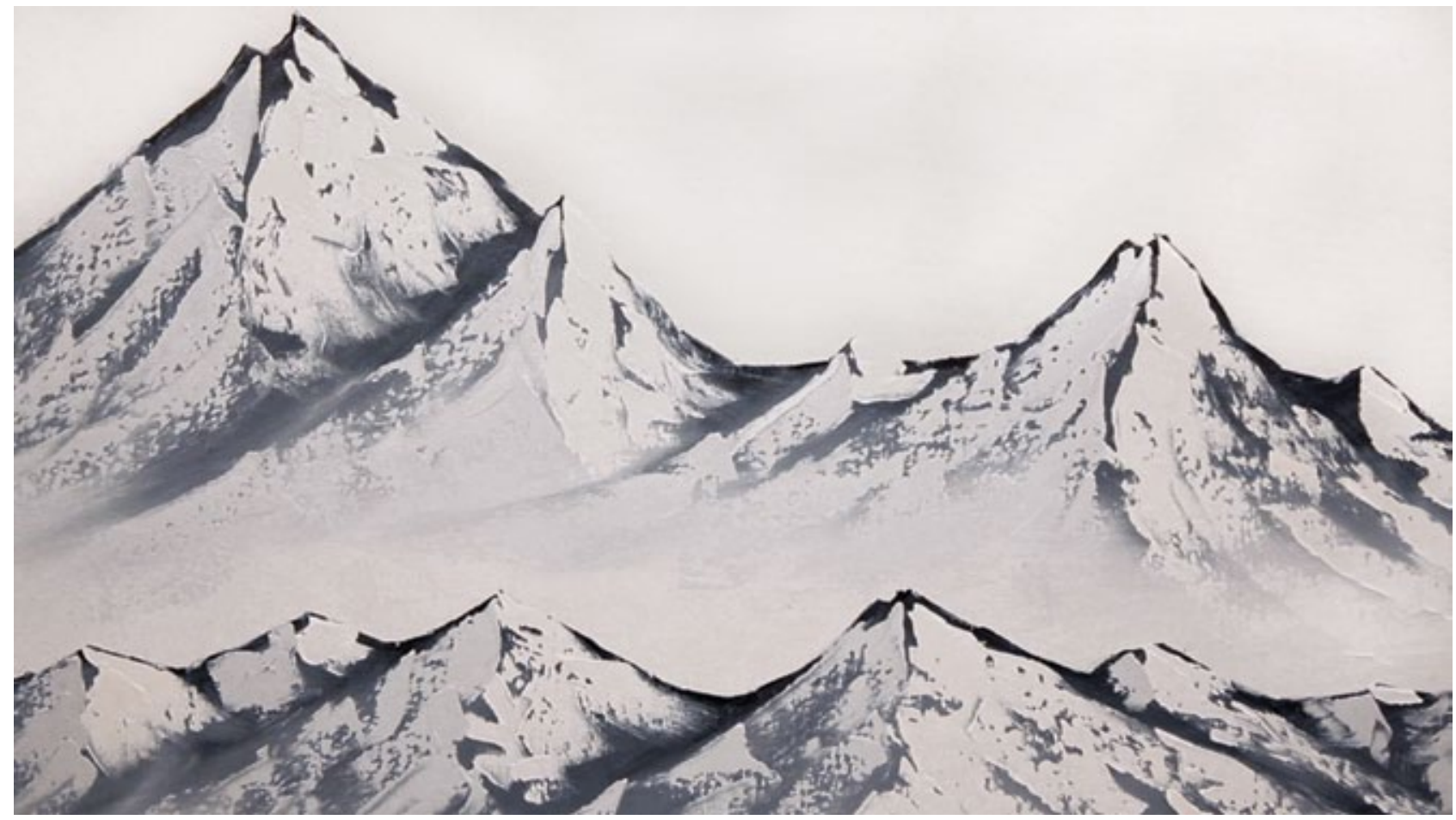

Pronto! É este o aspecto que seus picos nevados devem ter.

\section{Vá além}

Agora você já pode pintar quantos picos nevados desejar. Planeje, então, formas de multiplicar essa experiência e dividi-la com outras pessoas.

Há várias maneiras de fazer isso: produzir um vídeo tutorial e publicá-lo em DVD e no Youtube, realizar uma exposição em um espaço independente de arte ou promover uma oficina de pintura gratuita.

Você pode também aprofundar a discussão sobre o surgimento da noção de paisagem no Ocidente e sobre a representação paisagística na arte moderna, organizando um debate com estudiosos no tema.

Veja nas páginas a seguir o resultado de nossas experiências. 


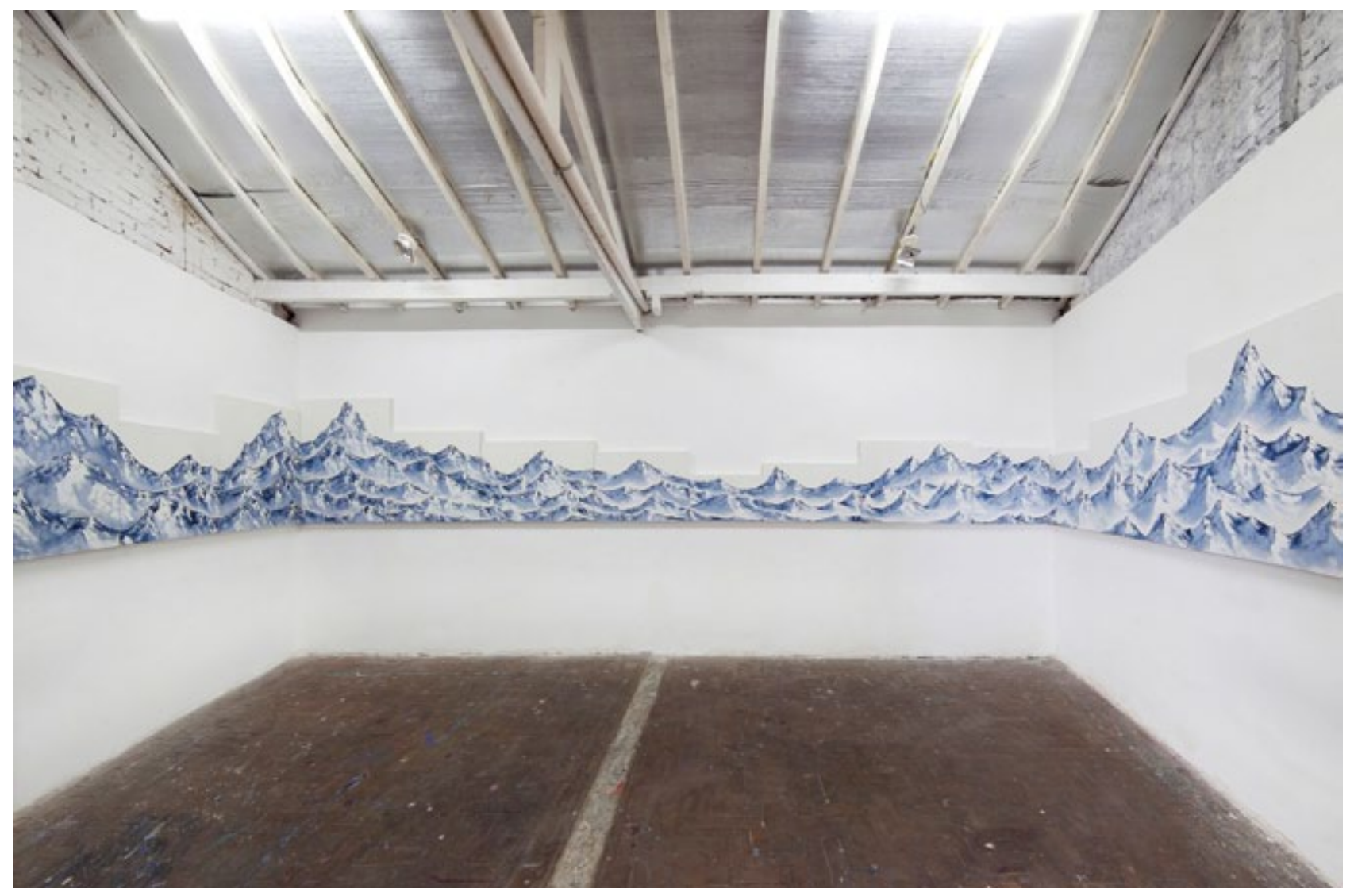

A exposição Como Pintar Picos Nevados foi montada de maneira a oferecer ao espectador uma visão panorâmica de uma cadeia de montanhas. 


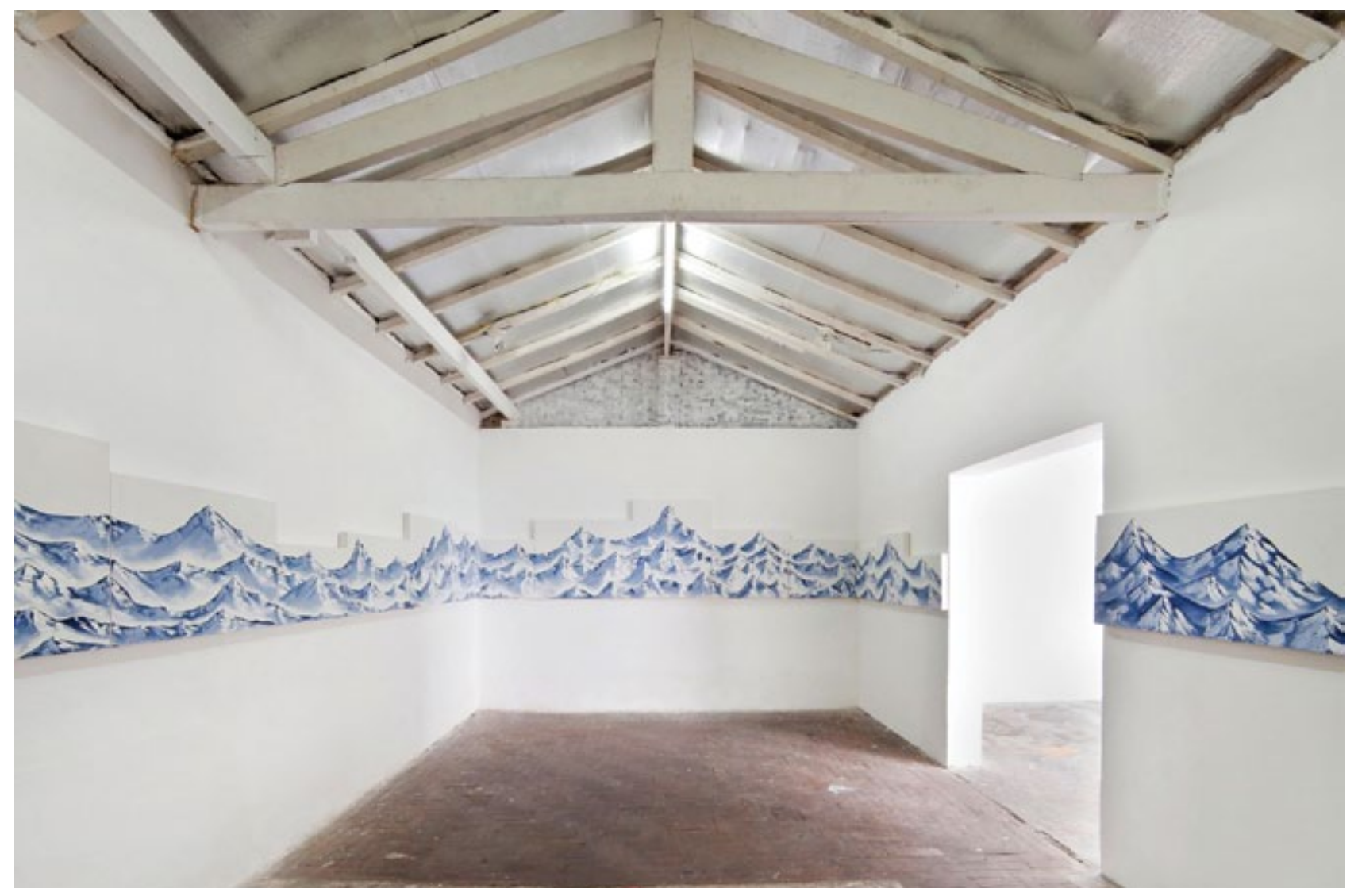

Faça a visita virtual à exposição no link:http://www.neoarte.net/360/picosnevados/index.html 


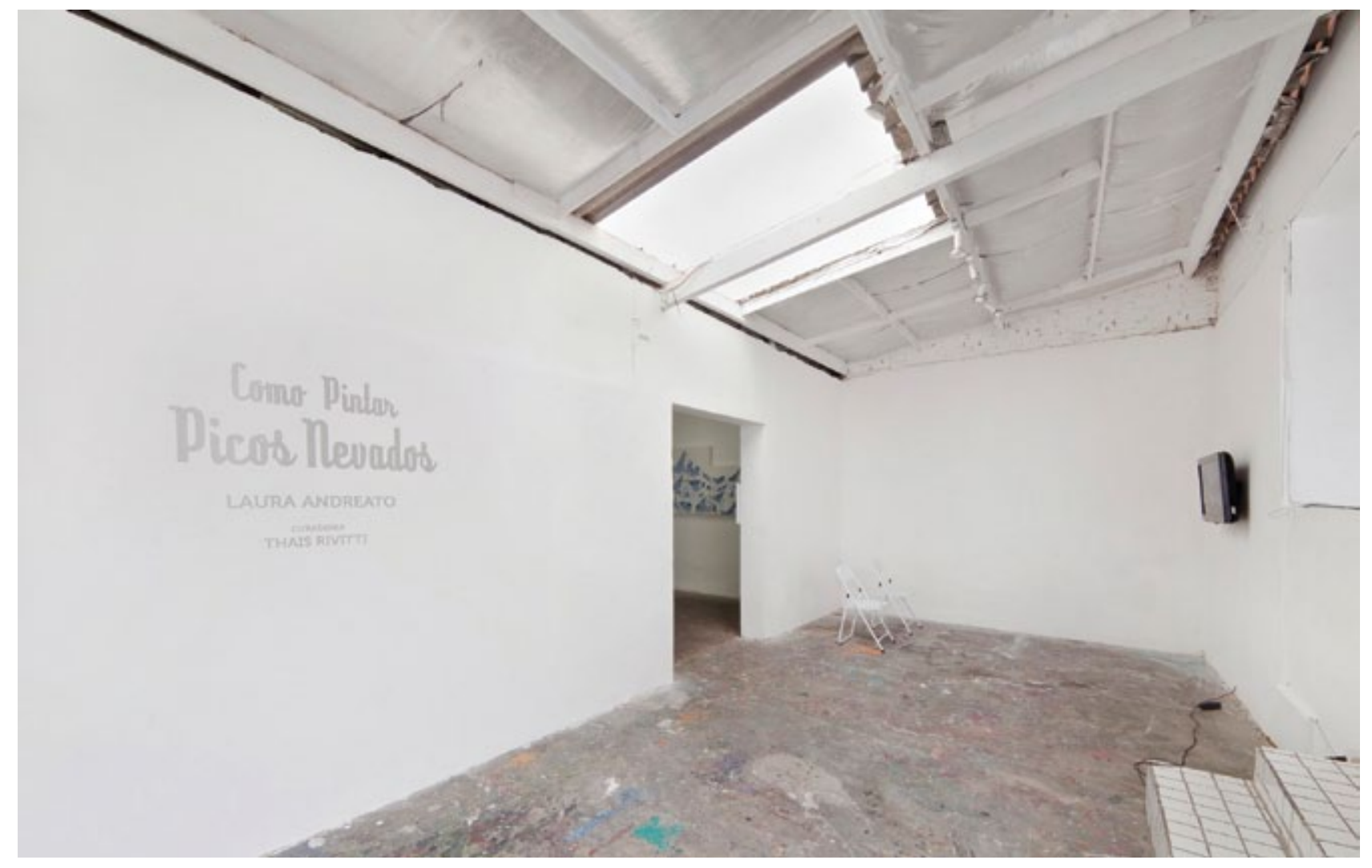

Antes da visita, os espectadores também podiam assistir ao vídeo Como Pintar Picos Nevados. 


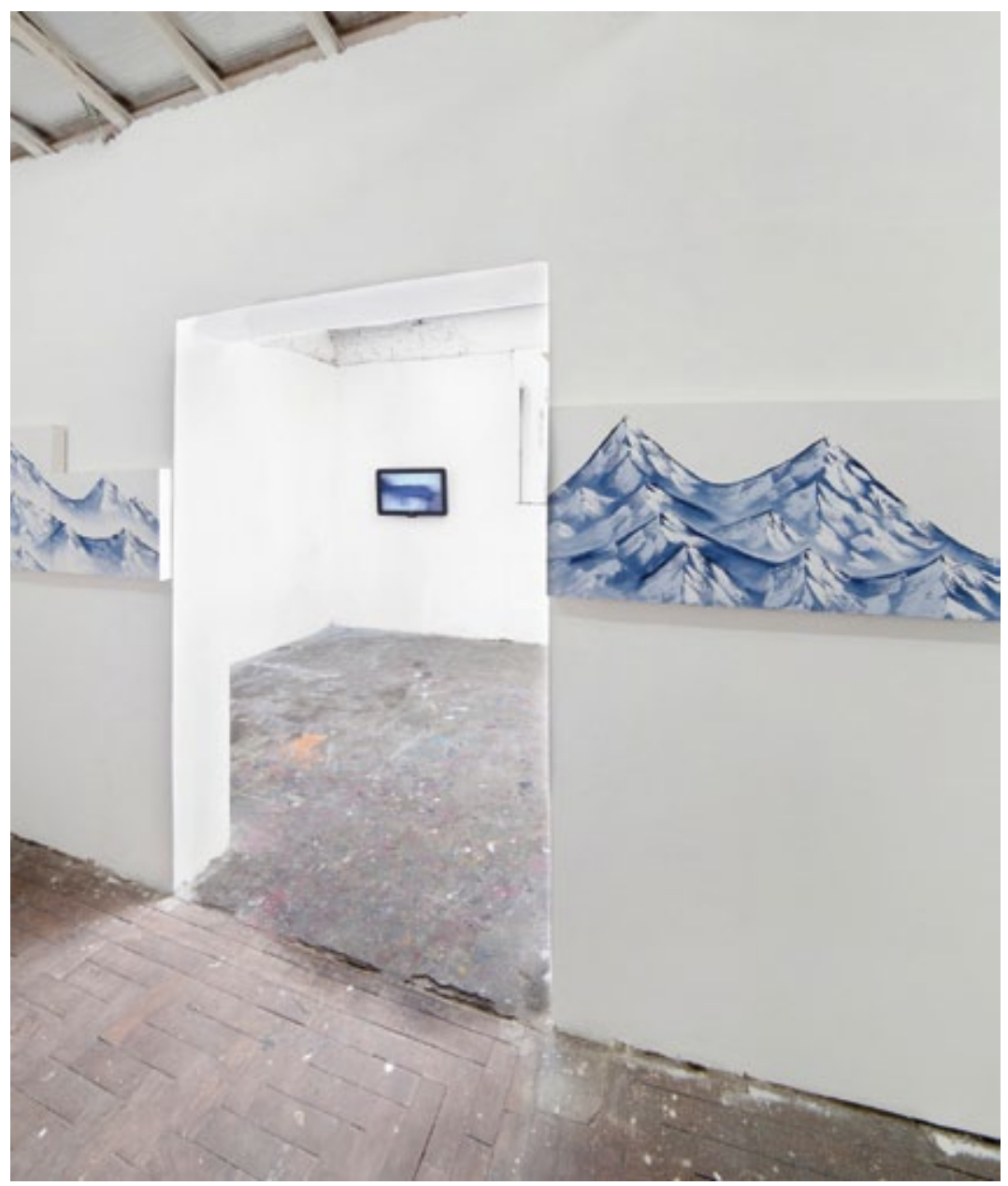


Veja detalhes das pinturas.

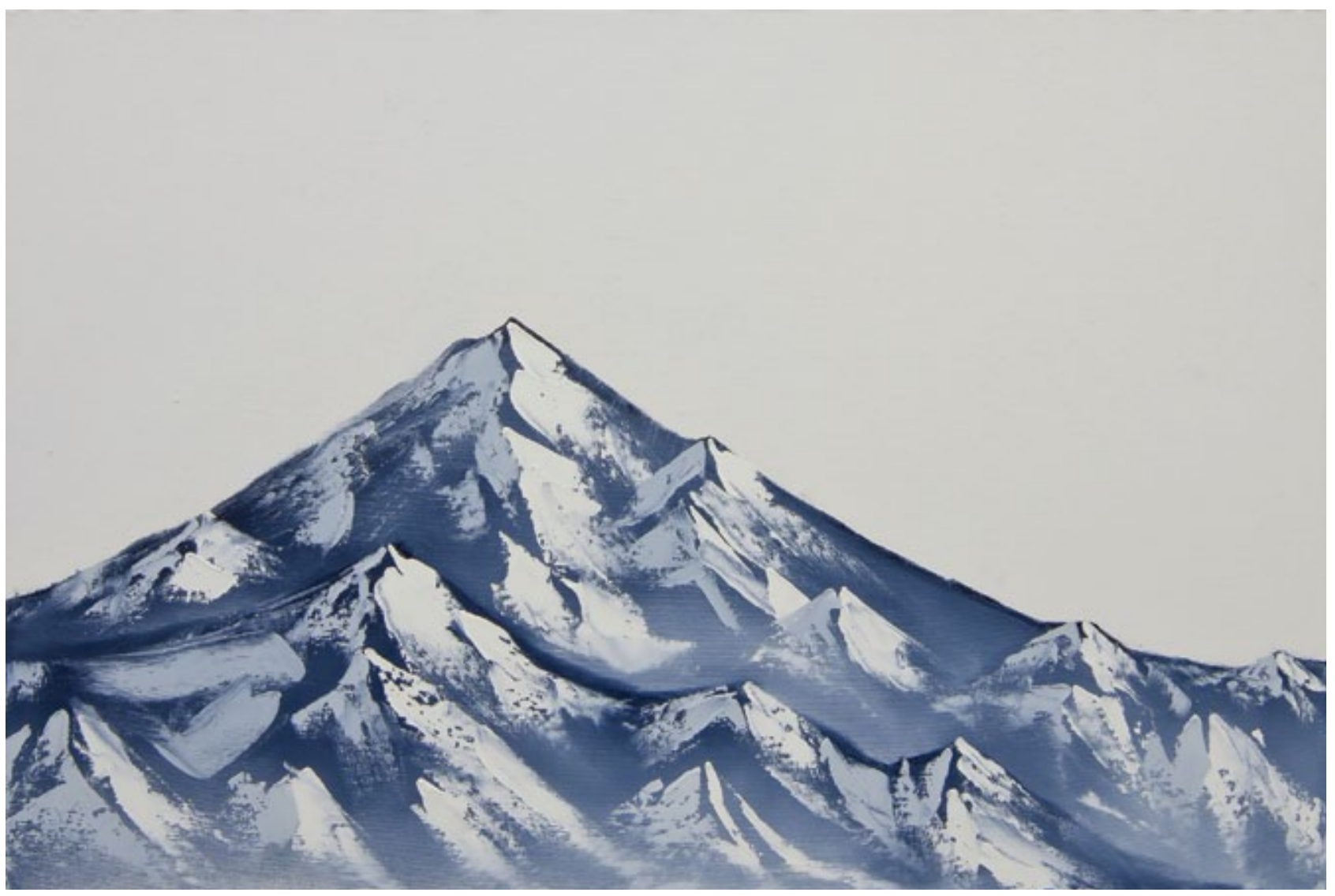




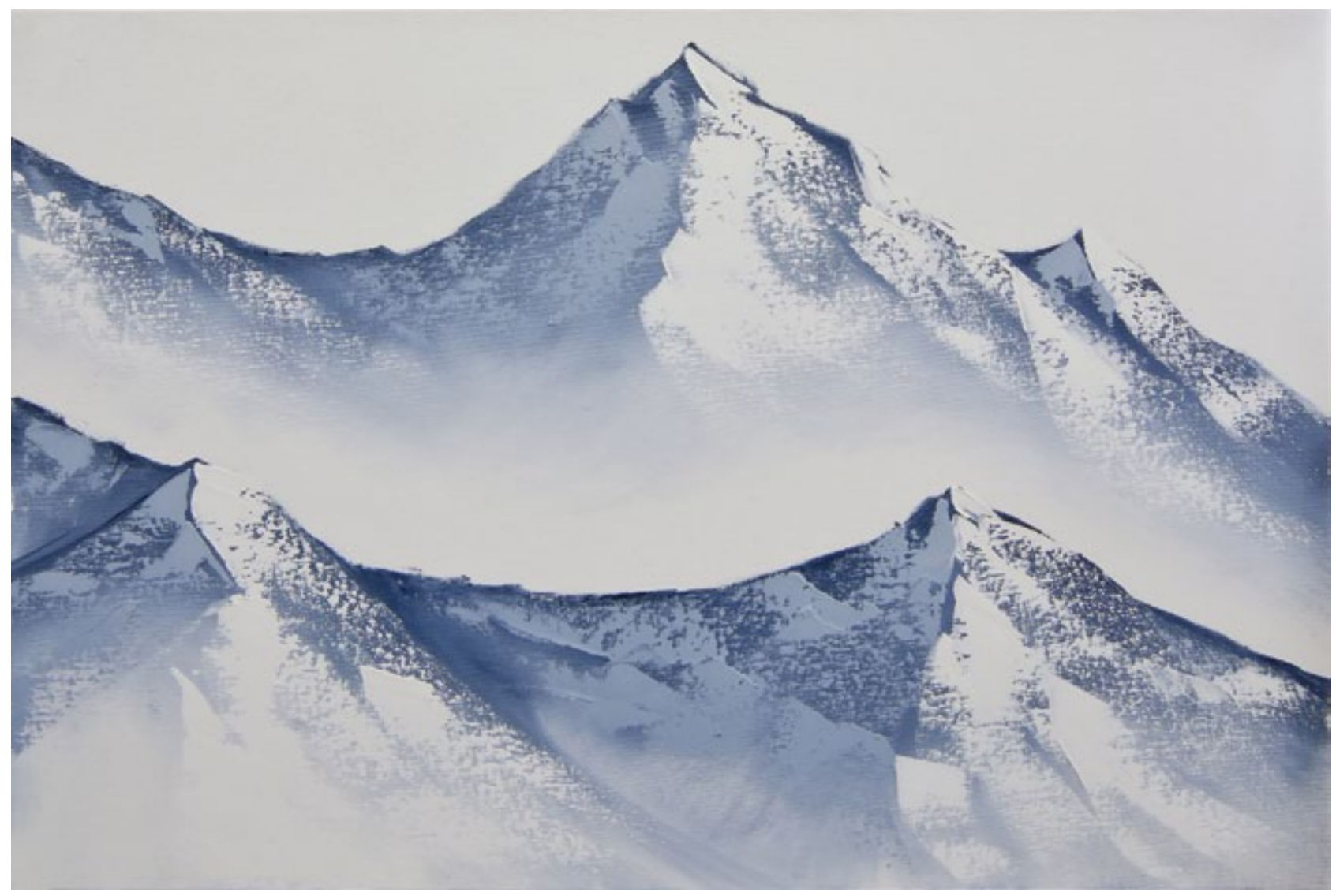



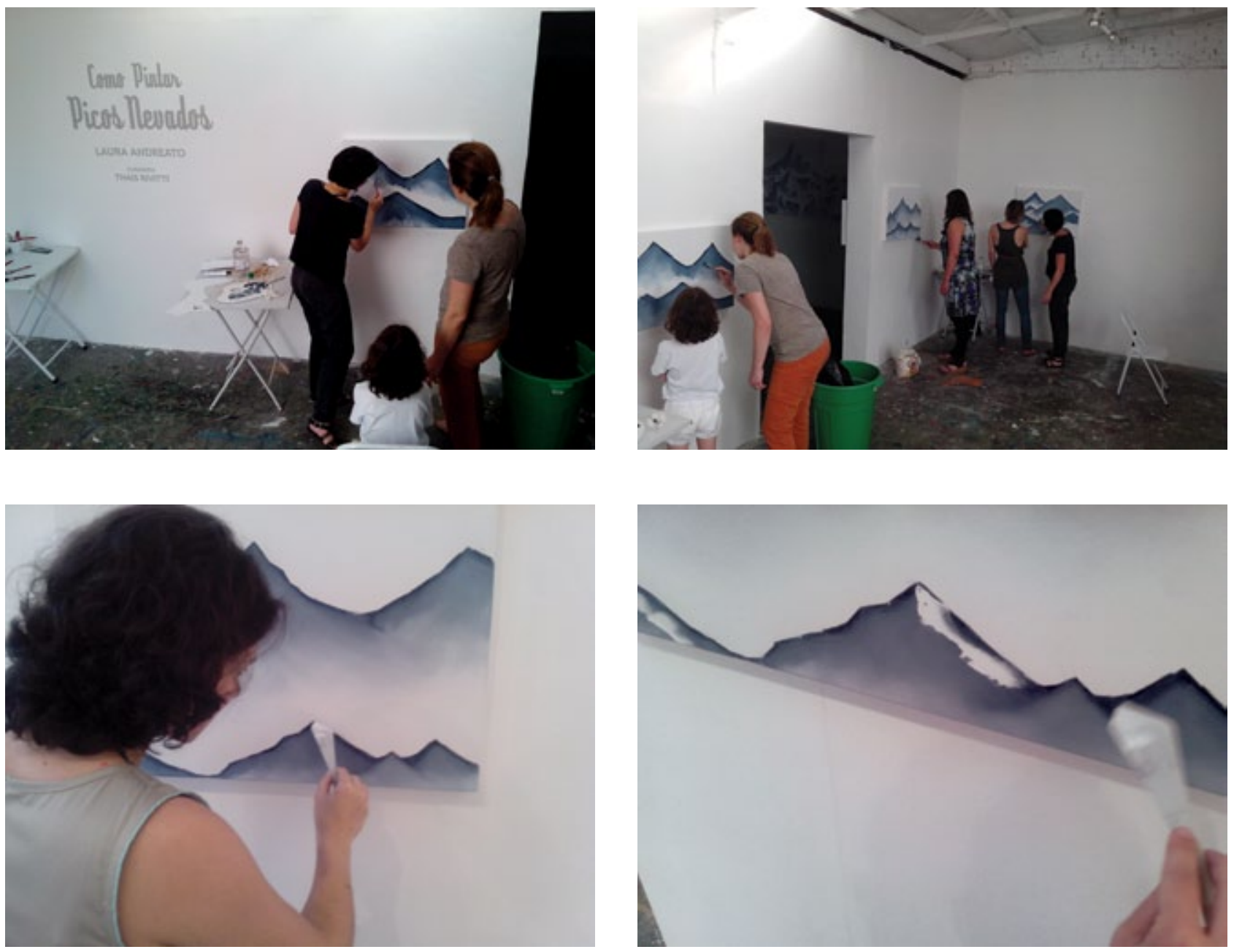

A oficina de pintura wet-on-wet Como Pintar Picos Nevados proporcionou um aprendizado eficiente aos participantes que seguiram de modo correto as instruções. 

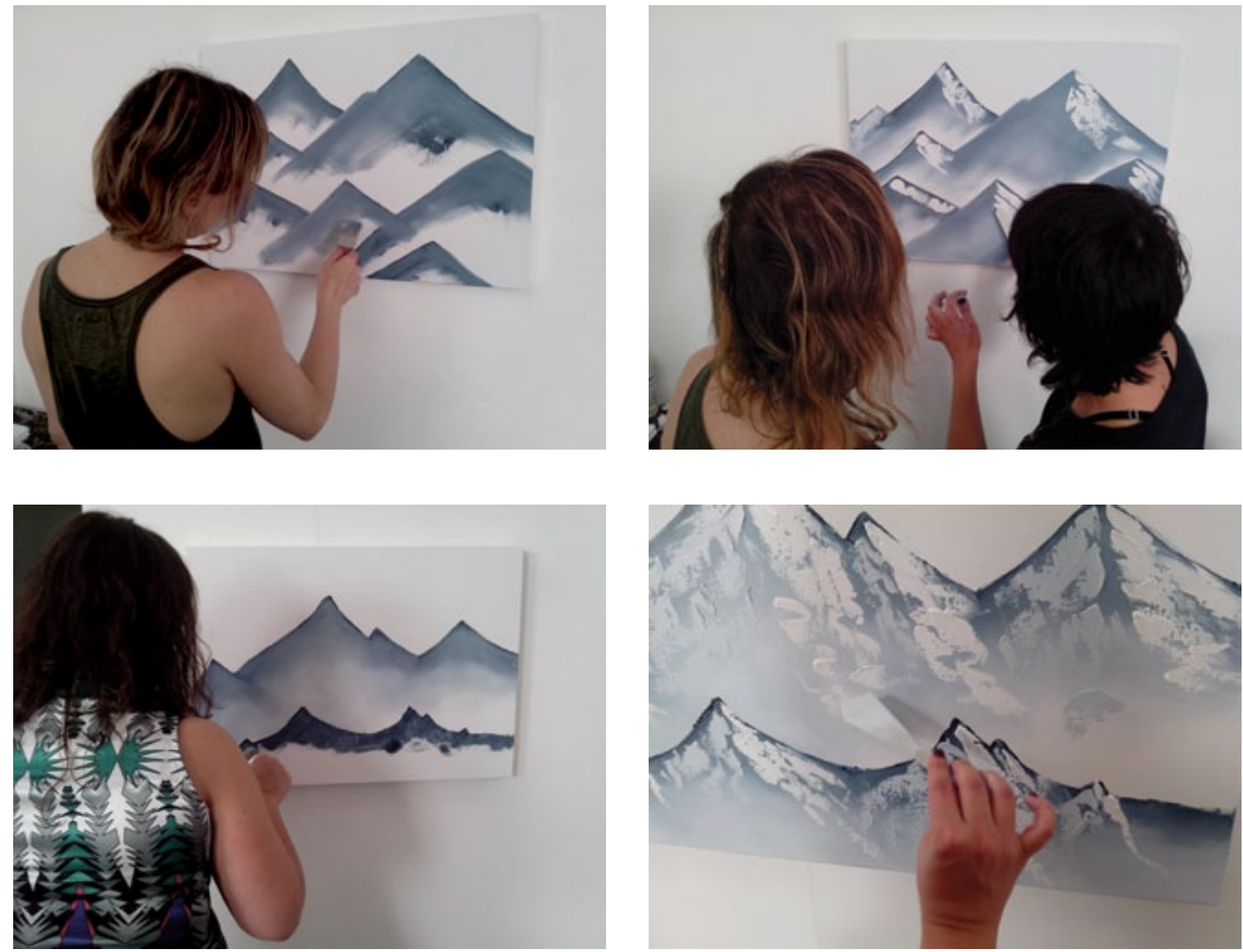

Note como as pinturas dos participantes ficaram parecidas com as da exposição. 
O vídeo tutorial Como Pintar Picos Nevados já tem mais de 65 mil acessos no Youtube ${ }^{14}$ e é o primeiro resultado quando se realiza uma busca com a expressão "como pintar picos nevados". Confira alguns comentários dos aprendizes virtuais!

\section{You Tube ${ }^{\text {BR }} \equiv-$}

\section{Como Pintar Picos Nevados}

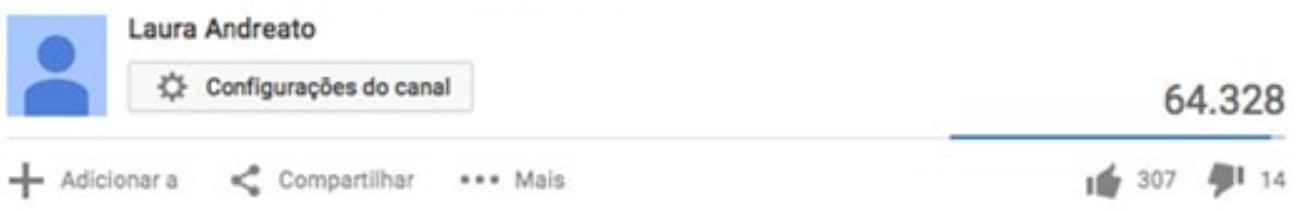

Publicado em 26 de set de 2013

Com este video, você vai aprender a pintar belos picos nevados, utilizando a simples e descomplicada técnica de pintura wet on wet. Em poucos minutos, como milhares de pessoas ao redor do mundo, vocês serăo capazes de reproduzir uma fascinante paisagem que todos văo adorar.

MOSTRAR MAIS

TODOS OS COMENTÁRIOS (19)

Compartilhe suas ideias

Principais comentários -

* Há comentários para aprovaplo. Anallisar comentírios

Caura Andreato Compartilhado no Google+ * 1 ano atrás

Responder . If 71

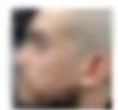

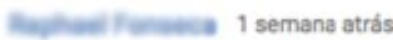

obrigado, Laura. já comecei a pintar os picos nevados nas paredes de casa. <3

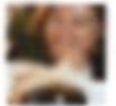

Con iacher inelta 3 meses atrás

Conque facilidad lo a echo,posible su explicación y técnica.Muchas gracias. Buena vida.

Responder * 1

1 tre 1 semana atrás

Very nice and helpful video review...

Responder .

14 De acordo com acesso em 30 de julho de 2015 
Valier Cullas 3 meses atrós

Excelente, era o que eu procurava. Parabéns.

Responder

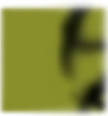

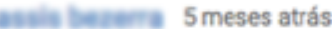

muito legal!

Responder

Theses atrás

precioso video muy bien esplicado gracias y saludos

Responder + 6 , 71

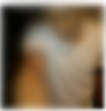

पineses atrás

Se aser rostros pero me gustaría pintar

Responder

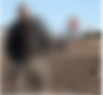

Liemage Hilance 8 meses atrás

Qué tipo de pintura has empleado Laura zoleo o acrílico ?????Obrigato

Responder

\section{Cranturatore 6 meses atrás}

me encanto tu video ya pinte picos nevados,me gustaria saber mas soy de argentina y pinto con acrilicos espero ver otros videos tuyos decime como ver otros gracias

Responder . If 51

\section{Casubs Montenegro 7 meses atrás}

"Como Pintar Picos Nevados" parece ser uma das modalidades da pintura realística mas na minha opiniăo năo expressa de forma plena a criatividade do brasileiro isto porque com minimas variaçōes um quadro fica igual ao outro... Mas dentro deste mote o desafio seria "Como Pintar Nevos Picados" imergindo o artista num mundo de total subjetivismo e criação. Responder $\cdot 1$ 1 91

Traule Mifler 9 meses atrás

pintar montanhas e picos altos é o meu foco é muito atraenteja me falararan porque gosto tanto de pintar montanhas brancas, é que vivo loje delas

Responder .

Fatima Counallari 10 meses atrás

Simplesmente maravilhoso. Parabéns ao artista.

Responder . 3 is 51 



\section{Referências bibliográficas}

ACOSTA, Daniel A. Paisagem Portátil: arquitetura da natureza estandardizada. Tese de Doutorado, São Paulo: ECA/USP, 2005.

ADES, Lola. Small paintings that sell. Coleção How to draw and paint. Laguna Hills: Walter Foster Publishing.

ADORNO, Theodor W. Indústria cultural e a sociedade. São Paulo, Paz e Terra, 2002.

ALEXANDER, W. Secrets to the magic of oil painting. Coleção How to draw and paint. Laguna Hills: Walter Foster Publishing.

AUGÉ, Marc, L’impossible Voyage: le tourisme et ses images, Payot \& Rivages, Paris, 1997

ARISTÓTELES. Arte poética. São Paulo: Ed. Martin Claret, 2004

BAUDRILLARD, Jean, O sistema dos objetos. São Paulo: Perspectiva, 2002

Para uma crítica da economia política do signo. São Paulo: Martins Fontes, 1972

Simulacros e simulação. Lisboa: Relógio d’Água, 1991.

A arte da desaparição, Editora UFRJ, 1997

BELTING, Hans. Por uma antropologia da imagem. Concinnitas, Rio de Janeiro, ano 6, volume 1, número 8, p. 65-78, 2005.

BENJAMIN, Walter. Passagens. Belo Horizonte: Editora UFMG; São Paulo: Imprensa Oficial do Estado de São Paulo

Obras escolhidas, v. II, Rua de mão única, trad. de R.R. Torres F. e J.C.M. Barbosa, São Paulo: Brasiliense, 1987.

A obra de arte na época de sua reprodutibilidade técnica. In: ADORNO et al. Teoria da cultura de massa. Trad. de Carlos Nelson Coutinho. São Paulo: Paz e Terra, 2000. p. 221-254. 
BESSE, Jean-Marc. Ver a Terra: seis ensaios sobre a paisagem e a geografia. São Paulo, Perspectiva, 2006.

BODÓ, Bela e Jan. Paisagens a óleo 1. Coleção Como desenhar e Pintar. Laguna Hills: Walter Foster Publishing.

BOIS, Alain; KRAUSS, Rosalind E. Formless: a user's guide. Centre Georges Pompidou, Paris, 1996 BOYER, Marc. História do turismo de massa. tradução Viviane Ribeiro, Bauru-SP. EDUSC, 2003

CARVALHO, Nelly. Publicidade, a linguagem da sedução. 3. ed. São Paulo: Ática, 2000

CAUQUELIN, Anne. A invenção da paisagem. São Paulo: Martins Fontes, 2007

CERTEAU, Michel: A invenção do cotidiano: 1. Artes de fazer. Petrópolis: Vozes, 2008

CLARK, Kenneth - Paisagem na Arte. Lisboa, Editora Ulisseia, 1949.

CORBIN, Alain - O território do vazio - a praia e o imaginário ocidental. São Paulo, Companhia das Letras, 1989.

COZENS, Alexander. A New Method of Assisting the invention in Drawing Original Compositions of Landscapes. in TAYLOR, Joshua C. Nineteenth-Century Theories of Art. California: University of California Press,1987

DARDEL, Eric. O homem e a Terra. Natureza da realidade geográfica. São Paulo, Perspectiva, 2011.

DA VINCI, L., Tratado de Pintura, trad, Angel González García 2º ed., Madrid, Ed, Akal, 1993

DEBORD, Guy; WOLMAN, Gil. Um guia para usuários do deturnamento

Trad. Railton Sousa Guedes. Arquivo Situacionista Brasileiro/Projeto Periferia (www.geocities. com/projetoperiferia5/is.htm). Acesso em 12 fev. 2015 
ELLIS, Markman . Spectacles within doors: panoramas of London in the 1790 s.

Disponível em http://qmro.qmul.ac.uk/jspui/handle/123456789/3559 acesso em 05 mai. 2015

GHIRRI, Luigi. Pensar por imagens. São Paulo: IMS, 2013

GOMBRICH, Ernst Hans. Arte e llusão: um estudo da psicologia da representação pictórica. Tradução Raul de Sá Barbosa. São Paulo: Martins Fontes, 1995.

HEGEL, G.W.F., Estética. Tradução. Orlando Vitorino, Lisboa: Guimarães editores,1993

HOUAISS, A. e VILLAR, M. de S. Dicionário Houaiss da Língua Portuguesa. Instituto Antonio Houaiss de Lexicografia e Banco de Dados da Portuguesa. Rio de Janeiro: Objetiva, 2001.

KRIPPENDORF, Jost. Sociologia do turismo: para uma nova compreensão do lazer e das viagens. trad. Contexto Traduções. São Paulo: Aleph, 2000

LIMA, Catharina P.C dos Santos. Natureza e Cultura: o conflito de Gilgamesh in Paisagem e Ambiente: Ensaios, São Paulo, n. 18, p. 7-57, 2004

LIMA, Luiz Costa. Teoria da cultura de massa. São Paulo: Paz e Terra, 2002.

MARSHALL, Richard D. Ed Ruscha. Londres: Phaidon Press limited, 2005

MICHAELIS: Moderno dicionário da língua portuguesa. São Paulo:

Companhia Melhoramentos, 1998

MOUNT, Harry. How a frenchman invented the english garden. The Telegraph Londres, 08 oct. 2011. Disponível em http://www.telegraph.co.uk/culture/art/art-news/8814567/How-aFrenchman-invented-the-English-garden.html acesso em $17 \mathrm{fev} .2015$

MUSEU DE ARTE MODERNA DE SÃO PAULO, Ecológica: catálogo. São Paulo: Museu de Arte Moderna de São Paulo, 2010 
PLATÃO. A República. São Paulo: Martin Claret, 2000.

PLINIO, O VELHO. História natural. Livro XXXV. Tradução: Magnólia Costa (coord.). In: LICHTENSTEIN, J. (org.) A pintura. Vol. I. O mito da pintura. São Paulo: Ed. 34, 2004.

RIBON, Michel. A arte e a natureza. Campinas: Papirus, 1988.

RITTER, Joachim. Paysage - Fonction de L'Esthétique dans la Societé Moderne. Besançon, Les Éditions de Ulmprimeur, 1997

ROGER, Alain - Court traité du paysage. Mayenne, Éditions Gallimard, 1997.

O Nascimento da Paisagem no ocidente. In: ICOLÓQUIO INTERNACIONAL DE HISTÓRIA DA ARTE COMITÊ BRASILEIRO DE HISTÓRIA DA ARTE/ Comitê International d'Histoire de l'Art São Paulo 5-10 de setembro de 1999. Tradução, para o português, de Vladimir Bartalini, para uso exclusivo da disciplina AUP5882 - Paisagem e Arte: Intervenções Contemporâneas, do Curso de Pós-Graduação da FAU-USP.

SANTAELLA, Lúcia. O que é Semiótica. São Paulo: Editora Brasiliense, 1985

SIMMEL, Georg. La tragédie de la culture et autres essais. Trad. Sabine Cornille, Philippe Ivernel. Paris, Rivages, 1988.

SKINNER, B. F. Sobre o Behaviorismo. Tradução Maria da Penha Villalobos. São Paulo: Cultrix, 1982.

Ciência e Comportamento Humano. São Paulo: Martins Fontes, 1998.

SONTAG, Susan. Sobre fotografia. São Paulo: Companhia das Letras, 2004.

TAM VIAGENS. Menu do viajante. Maio/junho 2015. São Paulo: TAM Viagens. 2015.

TAM VIAGENS. Menu do viajante. Abril/maio 2015. São Paulo: TAM Viagens. 2015. 
VENTURI, Robert; Brown, Denise Scott; Izenour, Steven. Aprendendo com Las Vegas, São Paulo: Cosac Naify, 2003.

WANDS, Alfred. Mountais. Coleção How to draw and paint. Laguna Hills: Walter Foster Publishing.

ZUKIN, Sharon. Landscapes of Power: From Detroit to Disney World. University of California Press, 1991.

Paisagens do século XXI: notas sobre a mudança social e o espaço urbano, in A. A. ARANTES (org.), 0 espaço da diferença, Campinas, Papirus, 2000

\section{Sites acessados}

www.bobross.com acesso em 08 fev. 2015

https://en.wikipedia.org/wiki/Panoramic_painting acesso em 08 jun. 2015

http://vacancehotel.com.br/hotel/historia, acesso em 08 jul.2015

http://www.vacancesturismo.com.br , acesso em 10 abr. 2015

http://www.rivivere.com.br/ acesso em 08 fev. 2015

https://pt.wikipedia.org/wiki/Paradise_(Nevada) acesso em 08 fev. 2015 


\section{créditos das imagens}

caderno de imagens

p. 18 e 19: Educandário Dom Silvério, Cataguases, MG.

p. 20 e 21: Hotel Atlântico Business Centro, Rio de Janeiro.

p. 22: loja Kalunga, São Paulo.

p. 23 e 24: Müren, Suíça.

p. 25: Jungfraujoch, Suiça.

p. 26: Ônibus turístico, São Paulo.

p. 27: Voyage modelo Comfortline 2015, São Paulo.

p. 28: Rua Oscar Freire, São Paulo.

p.29: Rua Scipião, Lapa, São Paulo.

p. 30: Cataguazes, MG

p. 31: Av. Arnolfo Azevedo, São Paulo.

p. 32: Loja Kalunga, São Paulo.

p. 33: Santa Cecília, São Paulo.

p.34: Goiânia, GO.

p. 35: Granité sabor Tropical Blue Lagon, Paris.

p. 36 e 37: Goiânia, GO.

p. 38: São Paulo.

p. 39: Rio de Janeiro.

p. 40 e 41: São Paulo.

p. 42: Aeroporto de Heathrow, Londres.

p. 43: Santa Cecília, São Paulo.

p. 44: Loja Leroy Merlin, São Paulo.

p. 45: Vila Mariana, São Paulo.

p. 46: Bananal, São Paulo.

p. 47: Museu Pergamon, Berlim.

p. 48: Termas de Széchenyi, Budapeste.

p. 49: Lauterbrunnen, Suíça.

p. 50: Les grandes serres (estufa), Jardin des Plantes, Paris.

p. 51: Museu Biológico do Instituto Butantan, São Paulo.

p. 52: Consultório odontológico, São Paulo.

p. 53: Mineração Caieiras materiais de construção, São Paulo.

p. 54: Loja Eden Shoes, Paris.

p. 55: Le Paradis, Bistrot de Quartier, Paris.

p. 56: imobiliária na Vila Mariana, São Paulo.

p. 57: Floricultura Mon Jardin, Posto Ipiranga, São Paulo.

p. 58: Fazenda Vargem Grande, Areias, SP.

p. 59: Jardim residencial, Cataguases, MG. obras

p. 85-89: Unidades Decorativas, 2007. Tijolos, cimento, massa corrida, tinta latéx e quadros.

p. 91-93: Balneário, 2008. Tinta látex, refletores e vinil adesivo. Funarte São Paulo. Fotos: Maurício Guerreiro.

p. 95-97: Depois de...2010. Acrílico recortado, lâmpada fluorescente vermelha. Programa Múltiplos 397.

p. 99-103: Café Vacance, 2009. Toldo, Backlight, Mesas, cadeiras mdf recortado, uniforme do funcionário. Funarte São Paulo. Fotos: Edi Pereira.

p. 105-107: Verão Luminosos, 2008. Backlight. Exposição Vistosa, em parceria com Ana Luiza Dias Batista e João Loureiro. Prêmio Conexão Funarte Artes Visuais. Fotos: Edouard Fraipont.

p. 109-113: Flórida, 2009. Registro de intervenções em estabelecimentos comerciais em são Paulo. Integra o projeto Nome Fantasia, apoiado pelo Proac Artes Visuais 2008.

p. 117-125: Delivery, 2009. Performance. Mostra Verbo 2009, Galeria Vermelho, São Paulo. Integra o projeto Nome Fantasia, apoiado pelo Proac Artes Visuais 2008. Fotos: Ding Musa.

p.127-127: Califórnia, 2009. Folder impresso na gráfica Califórnia, São Paulo. Integra o projeto Nome Fantasia, apoiado pelo Proac Artes Visuais 2008.

p. 129-133: Paradiso, 2012. Vinil adesivo, plantas artificiais, iluminação para jardins. Vitrines do Masp no Metrô. Estação Trianon-Masp, São Paulo. Fotos: Filipe Berndt.

p. 35-139: Mirage, 2011-2013.Registro de intervenção.

p. 46-151: Como Pintar Picos Nevados, 2013. Óleo sobre tela e vídeo. Ateliê 397, São Paulo, SP. Fotos Filipe Berndt 



\section{coleção arte contemporânea}
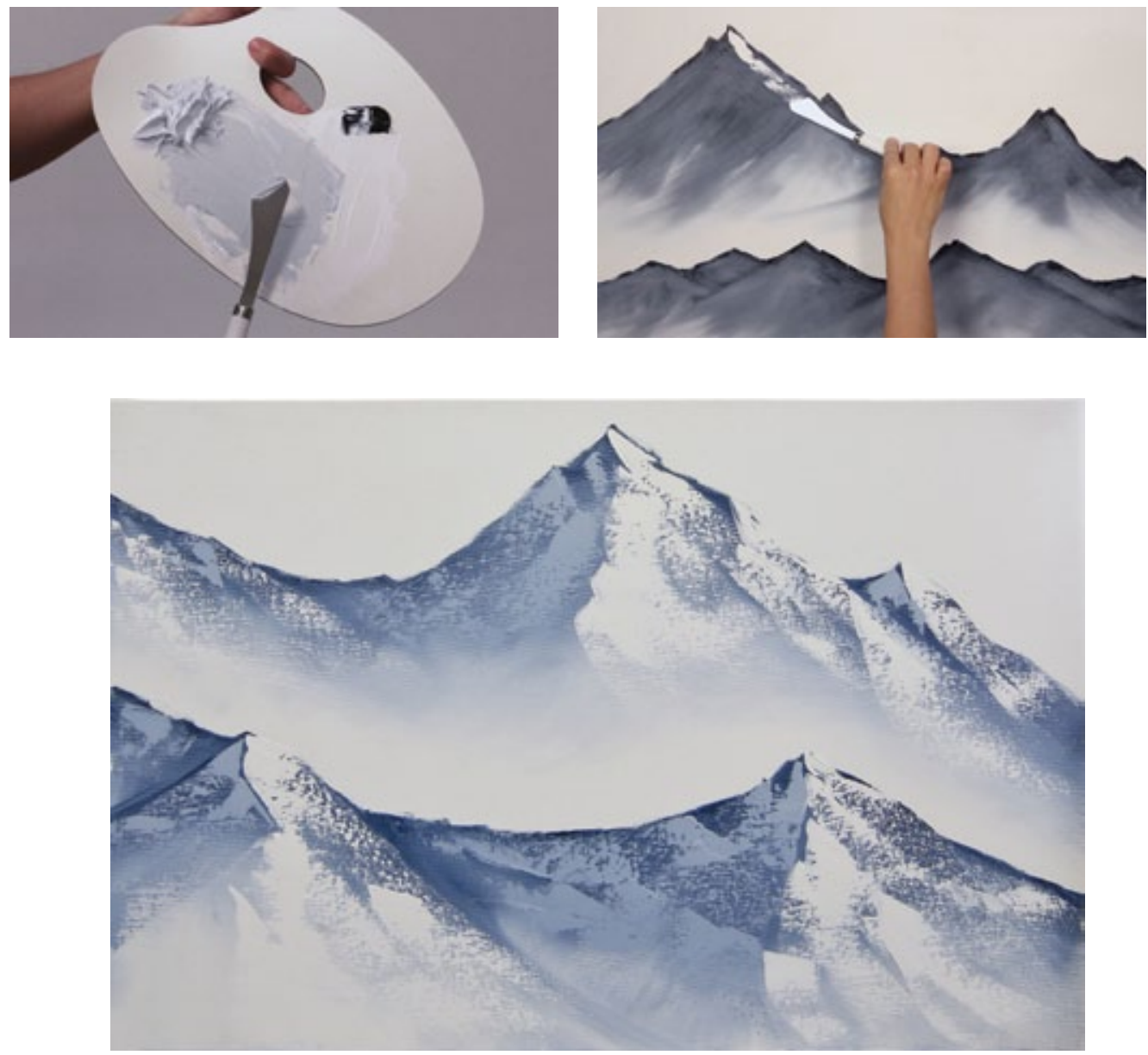